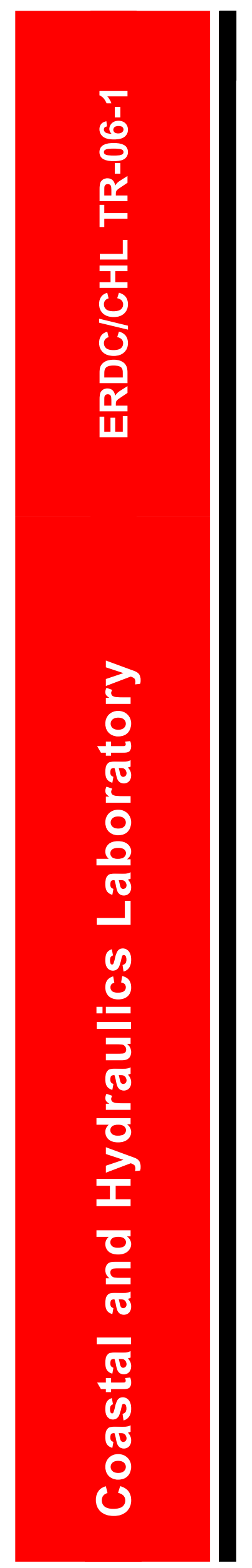

Coastal Inlets Research Program

\title{
Evaluation of Downdrift Shore Erosion, Mattituck Inlet, New York: Section 111 Study
}

Brian K. Batten and Nicholas C. Kraus

April 2006

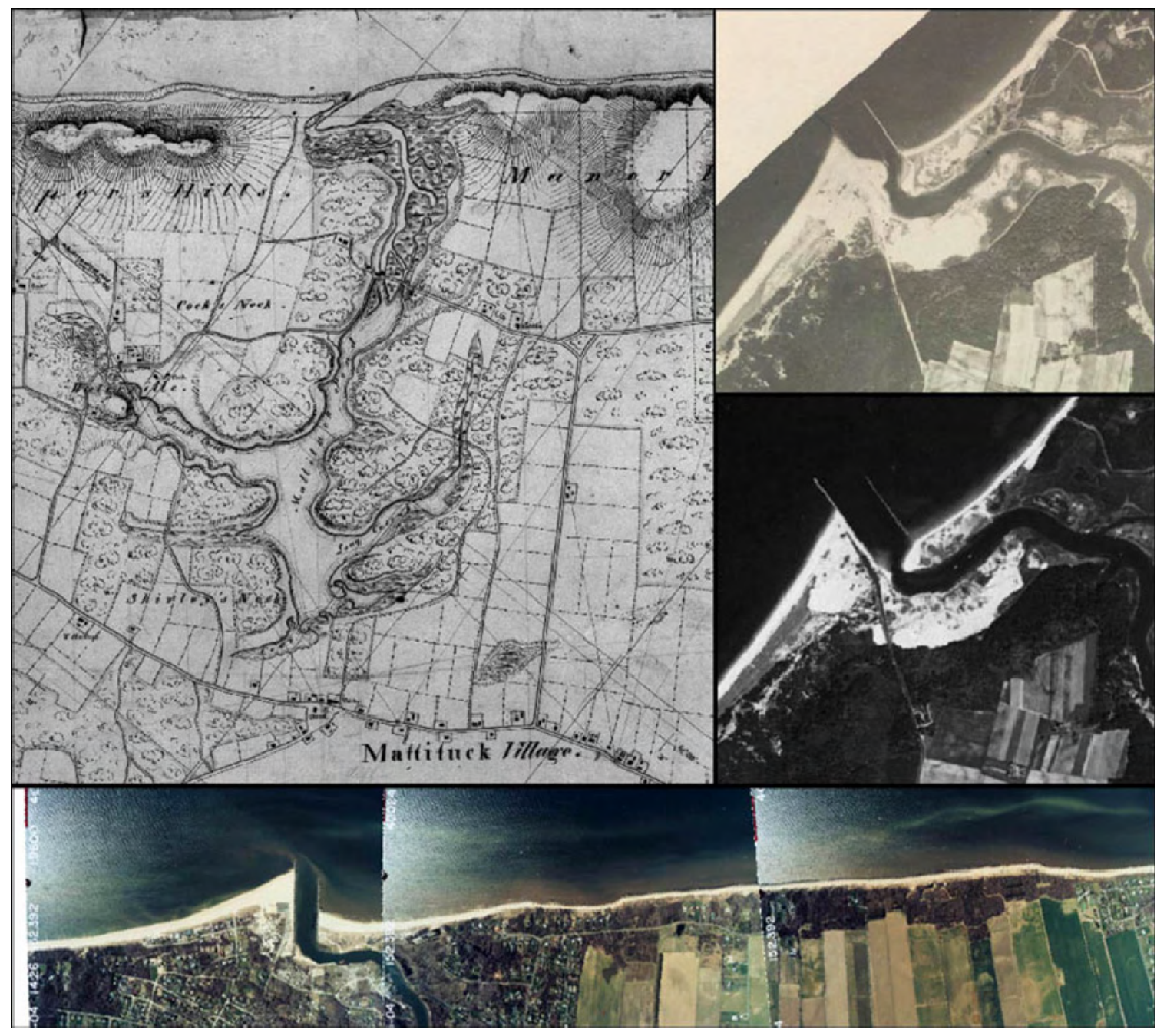




\section{Evaluation of Downdrift Shore Erosion, Mattituck Inlet, New York: Section 111 Study}

Brian K. Batten and Nicholas C. Kraus

U.S. Army Engineer Research and Development Center Coastal and Hydraulics Laboratory 3909 Halls Ferry Road

Vicksburg, MS 39180-6199

Approved for public release; distribution is unlimited

Prepared for U.S. Army Engineer District, New York 26 Federal Plaza

New York, NY 10278-0090

and U.S. Army Corps of Engineers

Washington, DC 20314-1000 


\begin{abstract}
This report was prepared for the U.S. Army Engineer District, New York, to evaluate shore erosion in response to construction of the Federal navigation project at Mattituck Inlet, NY, under the authority of Section 111 of the River and Harbor Act of 1968, Public Law 90-483, approved August 1968. The original navigation project was authorized in 1896 and modified in 1935 and 1964. The report is organized into seven chapters and two appendixes. Chapter 1 gives an introduction to Section 111 authority and the physical setting at the study site.

Chapter 2 discusses shoreline change and change rates in the vicinity of Mattituck Inlet. Shoreline change rates are calculated for the region and compared for shorelines adjacent to the inlet. Chapter 3 describes numerical simulations of waves, wave-induced and tidal currents, and sediment transport pathways at the inlet. Chapter 4 develops the sediment budget for the site and region. Chapter 5 describes estimated future conditions without a project. Chapter 6 evaluates the responsibility of the Federal government for downdrift shore erosion, and Chapter 7 presents alternatives for mitigation. Appendixes A and B document analysis results for shoreline change.

Federal responsibility for erosion downdrift of the Mattituck Inlet navigation project is determined by two approaches. The first approach evaluates the response of the adjacent shorelines to the project and is termed "explicit" because it gives a direct measure of shoreline recession and advance, hence, eroded and accreted volume, respectively, under standard assumptions. The evaluation includes measured shoreline change and the volume of material impounded updrift of the inlet. The second approach considers responses of the downdrift shoreline evaluated through a sediment budget and is termed "implicit" because it is based on transport rates alongshore and across shore that cannot be directly measured. Removal of material by maintenance dredging, as well as sand and gravel mining under both Federal and local permits, are addressed within the implicit approach.

Three alternatives are evaluated for mitigating shore erosion downdrift of Mattituck Inlet. The first alternative continues the present practice of beneficial placement of dredged material on downdrift beaches. This alternative effectively mitigates shore erosion only in the primary erosion area. The second alternative involves annual bypassing of material impounded updrift of the west jetty to downdrift beaches. This activity would increase bypassing rates to an estimated 75 percent of the average annual longshore transport rate. Benefits of this alternative include stabilization of the primary and secondary erosion areas, increased storm protection through wider beaches, and elimination of potential spit breaching adjacent to the inlet. This alternative improves on existing practice and does not mitigate past damage to the downdrift shorelines. The third alternative provides for advanced bypassing of material accumulated in the impoundment fillet, in addition to removal of portions of the flood shoal. An estimated volume of $125,000 \mathrm{cu}$ yd of material is available from these borrow areas for placement on downdrift beaches. The primary benefit of this alternative is increased storm protection along downdrift beaches, eliminating additional land losses and rebuilding costs associated with the Federal navigation project. Additional benefits include reduction of shoaling rates in the navigation channel, improvement of the channel condition, and enhanced circulation in Mattituck Creek.
\end{abstract}

DISCLAIMER: The contents of this report are not to be used for advertising, publication, or promotional purposes. Citation of trade names does not constitute an official endorsement or approval of the use of such commercial products. All product names and trademarks cited are the property of their respective owners. The findings of this report are not to be construed as an official Department of the Army position unless so designated by other authorized documents.

DESTROY THIS REPORT WHEN IT IS NO LONGER NEEDED. DO NOT RETURN TO THE ORIGINATOR. 


\section{Contents}

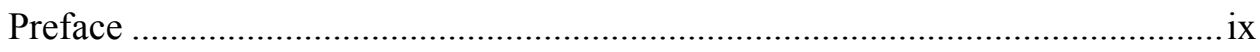

Conversion Factors: Non-SI to SI Units of Measurement ...................................xi

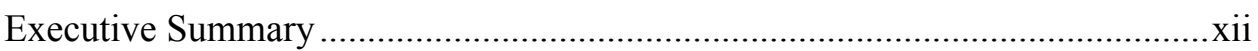

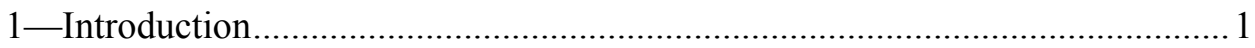

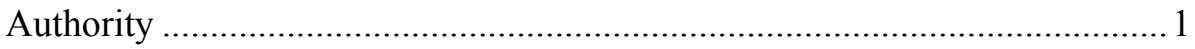

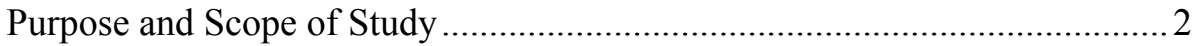

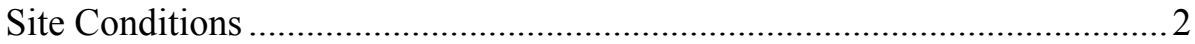

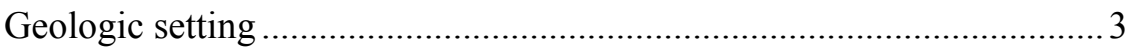

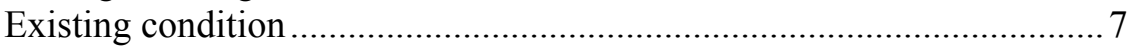

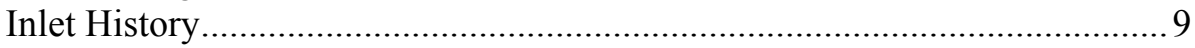

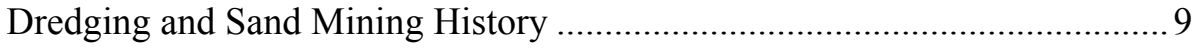

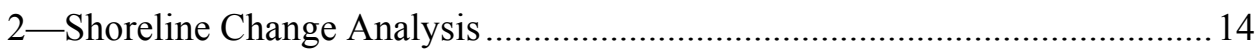

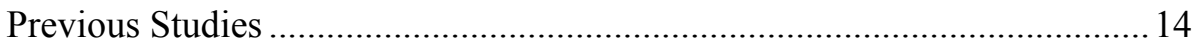

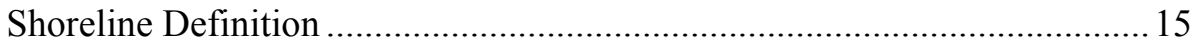

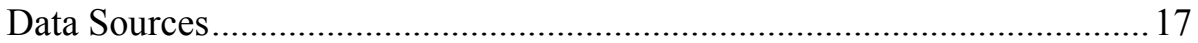

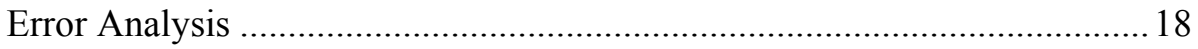

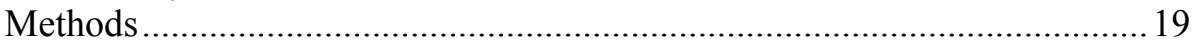

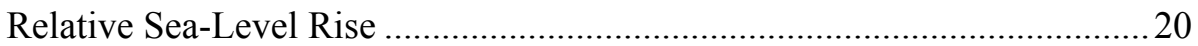

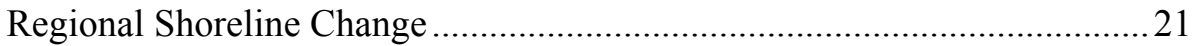

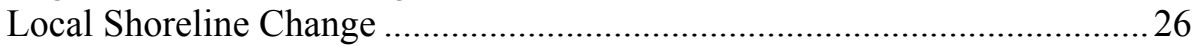

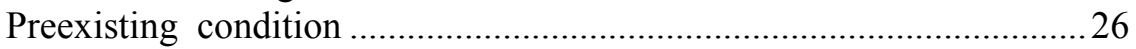

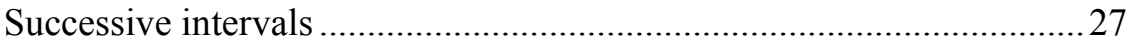

Delineation of impoundment and erosion areas...................................... 34

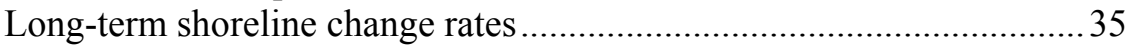

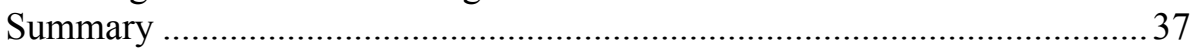

3-Hydrodynamics and Sediment Transport Modeling ..................................... 38

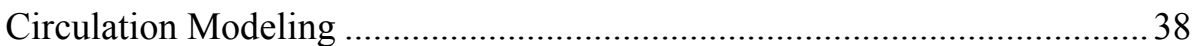

Horizontal Circulation Patterns ....................................................... 41

Sediment Transport Pathways at Entrance ................................................ 46 


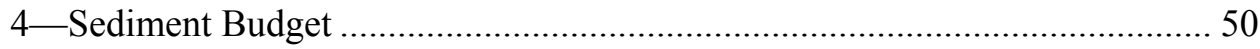

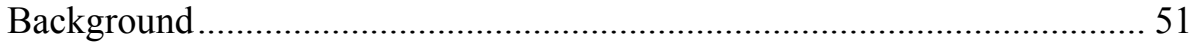

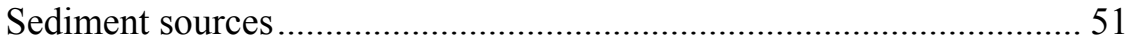

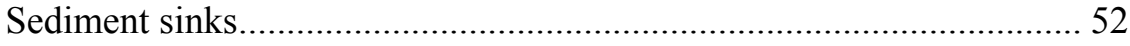

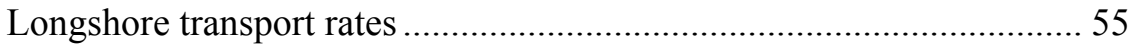

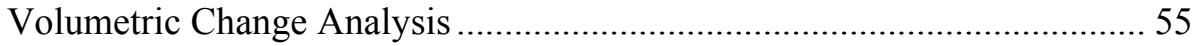

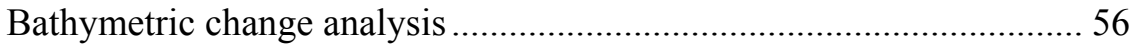

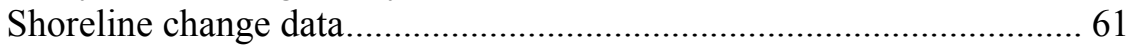

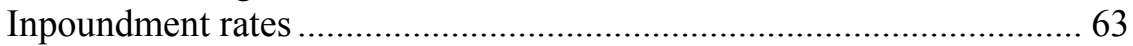

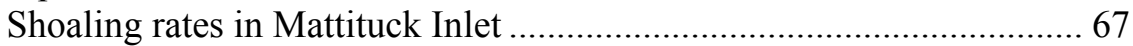

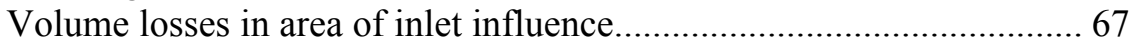

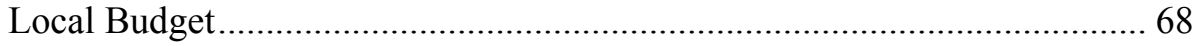

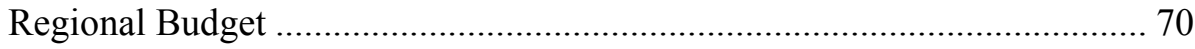

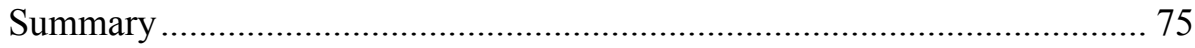

5-Future Without-Project Condition ............................................................... 77

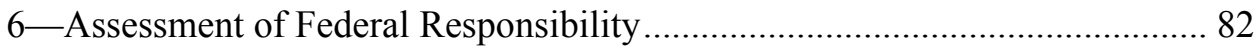

Explicit Assessment of Shoreline Change ................................................ 82

Implicit Assessment by Sediment Budget .................................................. 84

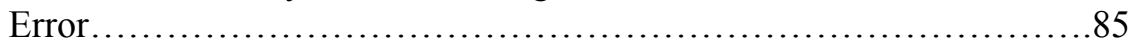

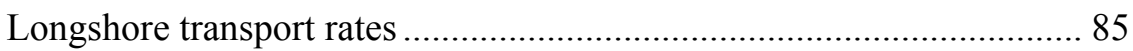

Total volume lost to downdrift beaches ........................................... 86

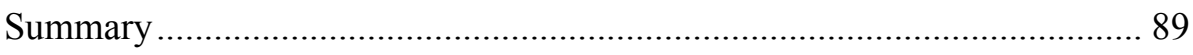

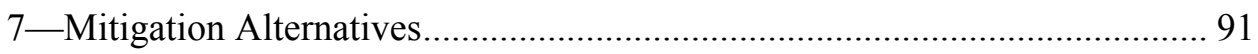

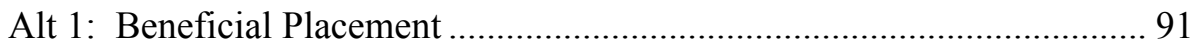

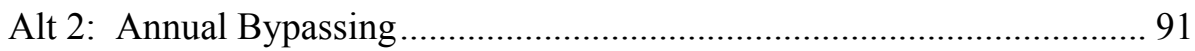

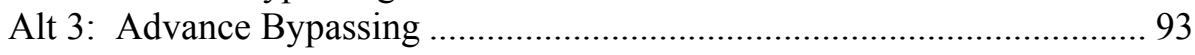

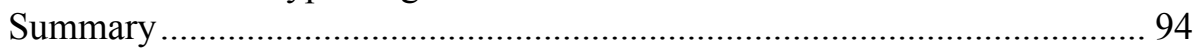

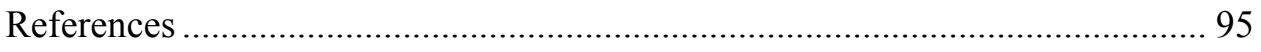

Appendix A: Shoreline Change Rate Graphs...............................................A1

Appendix B: Local Shoreline Chanage Rates by Interval .................................B1 


\section{List of Figures}

Figure 1. Location map for Mattituck Inlet, north shore of Long Island, NY ..... 3

Figure 2. Eastern north shore of Long Island, NY ........................................... 4

Figure 3. Mattituck Inlet and Creek, 1999 ...................................................... 4

Figure 4. Wind rose diagram for Mattituck Inlet, NY ..................................... 5

Figure 5. Looking westward from west jetty at Mattituck Inlet, March 2004 .... 8

Figure 6. View of coastline east of Mattituck Inlet, March 2004...................... 8

Figure 7. Sediment shoaling in Mattituck Inlet, circa 1930 ............................ 10

Figure 8. Example of interpreted shoreline, north shore of Long Island........... 16

Figure 9. Regional and local study areas for shoreline change rates................ 21

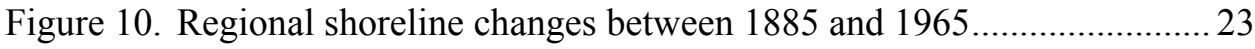

Figure 11. Regional shoreline changes between 1965 and 2001 .......................2 24

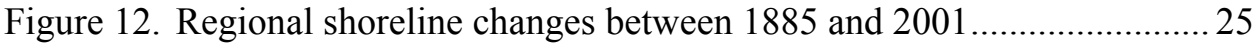

Figure 13. Mattituck Inlet and vicinity, 1838, NOS T-sheet T-55-1 .................. 26

Figure 14 Shoreline position and change rate between 1838 and 1885 ............ 27

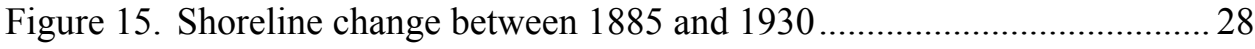

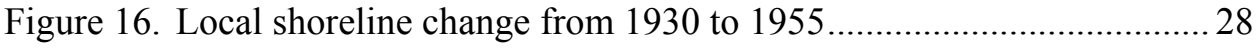

Figure 17. Photographs of Mattituck Inlet, 1938 and 1947 .............................. 29

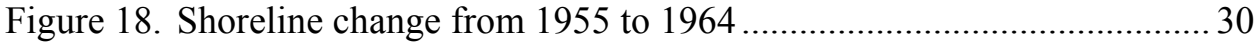

Figure 19. Material entering the littoral system at Northville as a result of sand mining, October 1969 ................................................................ 31

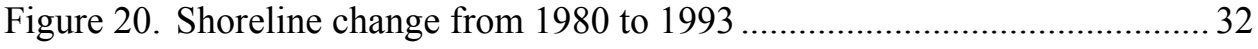

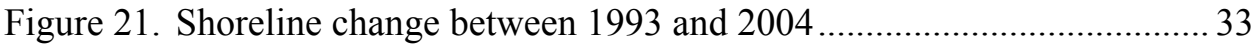

Figure 22. Dredged material placement directly downdrift of Mattituck Inlet, March 2004

Figure 23. Selected interpreted hwl shorelines east and west of Mattituck Inlet

Figure 24. Residual shoreline change rate in vicinity of Mattituck Inlet, 1885 to 2003

Figure 25. Areas of shoreline advance and recession overlaid on year 2000 aerial photography 35

Figure 26. Local shoreline change, 1885 to 2003 .............................................. 36

Figure 27. ADCIRC grid for Mattituck Inlet and location of site..... 39 
Figure 28. ADCIRC node structure at Mattituck Inlet and Mattituck Creek.......39

Figure 29. Location of the four speed comparison points...................................40

Figure 30. North flood shoal protruding into Mattituck Creek, 15 April 2004 ...41

Figure 31. Existing condition: plan view of maximum spring tide ebb current ..42

Figure 32. Dredged flood shoal: plan view of maximum spring tide ebb current

Figure 33. Existing condition: plan view of maximum spring tide flood current.

Figure 34. Dredged flood shoal: plan view of maximum spring tide flood current

Figure 35. Speed comparison of alternatives, sta 1

Figure 36. Speed comparison of alternatives, sta 2

Figure 37. Speed comparison of alternatives, sta 3 .45

Figure 38. Speed comparison of alternatives, sta 4 ..... .45

Figure 39. Comparison of calculated water levels, sta 4 ..................................46

Figure 40. IMS-M2D grid showing high resolution at Mattituck Inlet ...............47

Figure 41. Calculated depth change after 1 month, $0.2 \mathrm{~mm}$ sand.......................48

Figure 42. Calculated depth change after 1 month, $0.6 \mathrm{~mm}$ sand .......................49

Figure 43. Calculated depth change after 1 month, $0.2 \mathrm{~mm}$ sand, including flood shoal area

Figure 44. Example of large shoals off Roanoke and Jacobs Point ....................53

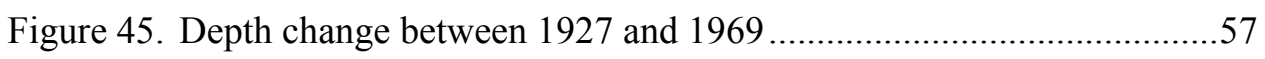

Figure 46. Depth change between 1969 and 2002 ............................................58

Figure 47. Depth change between 1927 and 2002 ............................................58

Figure 48. Depth changes between 1969 and 2002 .........................................60

Figure 49. Delineation of shoaling area and bypassing bar ...............................60

Figure 50. 3-D view of bathymetric surface change between the 1969 and 2002 and interpreted sediment bypassing pathways..........................61

Figure 51. Comparison of 1969, 1998, and 2001 profiles at sta C5 Mattituck Inlet .........................................................................62

Figure 52. Illustration of volume change sub-cell ........................................63

Figure 53. Impoundment updrift of Mattituck Inlet, year 2004 photograph........65

Figure 54. Budget for historical era ................................................................69

Figure 55. Sediment budget for modern era ….............................................. 70

Figure 56. Estimated 50-year shoreline advance in impoundment fillet .............78

Figure 57. Extrapolated 50-year shoreline based on present conditions produces little expected change in primary erosion area.. 
Figure 58. Estimated shoreline losses in secondary recession area .................79

Figure 59. Landward flanking of east jetty, 1941 ..........................................80

Figure 60. Present shoreline and beach compared to shoreline position in

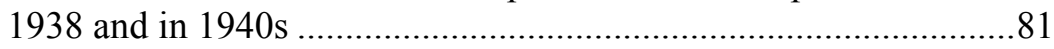

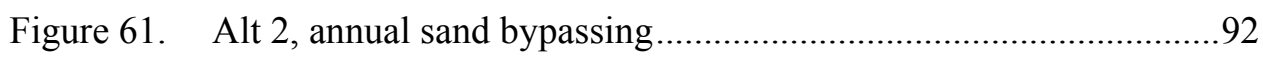

Figure 62. Areas of removal required to satisfy Alt 2 .................................93

Figure 63. Proposed borrow areas for Alt 3 ................................................. 94

Figure A1. Shoreline change, 1838 to 1885 ................................................A1

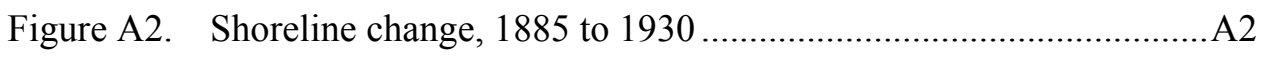

Figure A3. Shoreline change, 1930 to 1955 ................................................ 2

Figure A4. Shoreline change, 1955 to 1964 .................................................. 3

Figure A5. Shoreline change, 1964 to 1969 ................................................... 3

Figure A6. Shoreline change, 1969 to 1976 ..................................................A4

Figure A7. Shoreline change, 1976 to 1980 .................................................A4

Figure A8. Shoreline change, 1980 to 1993 .................................................A5

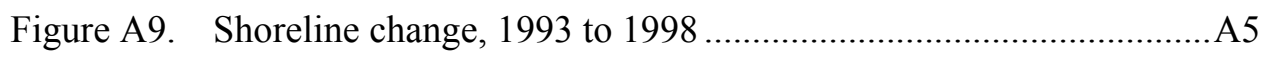

Figure A10. Shoreline change, 1998 to 2001 ................................................A6

Figure A11. Shoreline change, 2001 to 2003, note change in shoreline

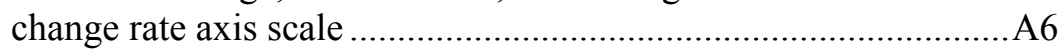

Figure A12. Shoreline change, 2003 to 2004, note change in shoreline change rate axis scale ......................................................... 7

\section{List of Tables}

Table 1. Average Significant Wave Height and Period....................................6

Table 2. Calculated Significant Wave Height and Period ................................6

Table 3. Relative Differences Between Tidal and Geodetic Datums, Mattituck, NY..... . .7

Table 4. Mattituck Inlet Dredging History ....................................................11

Table 5. Summary of Federal Commerical Mining Permits...............................11

Table 6. History of Sand Mining from Impoundment Fillet ............................13 


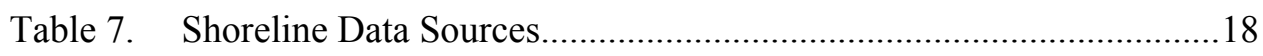

Table 8. Regional Shoreline Change Error...................................................19

Table 9. Local Shoreline Change Error .......................................................... 19

Table 10. Shoreline Recession Due to Sea-Level Rise.......................................20

Table 11. Long-Term Shoreline Change Rates ................................................36

Table 12. Assessment of Sediment Budget Data Sources .................................50

Table 13. Impoundment Fillet Growth Estimated by Fillet Area......................64

Table 14. Impoundment Fillet Growth Estimated by Shoreline Change Rate ...66

Table 15. Shoaling Rates in Mattituck Inlet ......................................................67

Table 16. Volume Losses Attributable to Mattituck Inlet ..................................68

Table 17. Regional Volume Change........................................................... 71

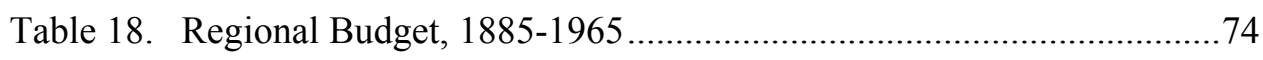

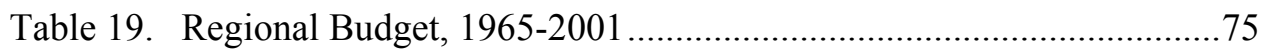

Table 20. Residual Recession Rates and Percent of Recession Attributed to

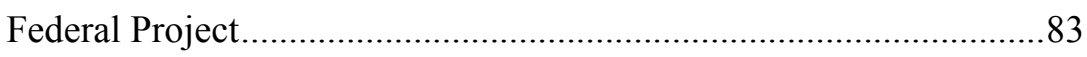

Table 21. Summary of Sediment Removal from Local Budget .........................87

Table 22. Total Volume Loss Attributable to Mattituck Inlet Federal

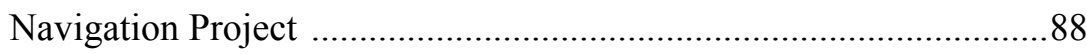

Table B1. Local Shoreline Change Rate by Interval....................................... B1

Table B2. Local Net Shoreline Change by Interval .........................................B1 


\section{Preface}

This report presents an analysis of the response of the downdrift beach to construction of rubble-mound jetties and a navigation channel at Mattituck Inlet, NY. The Federal navigation project at Mattituck Inlet entrance disrupted sediment transport to downdrift beaches. Sediment was impounded updrift of the west jetty, and a sediment deficit developed along the shore east of the inlet. This study was performed for the U.S. Army Engineer District, New York (NAN), by the U.S. Army Engineer Research and Development Center (ERDC), Coastal and Hydraulics Laboratory (CHL), Vicksburg, MS. This analysis was made to support an assessment of responsibility of the Federal government for beach erosion downdrift of the inlet and to identify and evaluate alternatives for mitigation.

A portion of the work described in the report was supported by the Coastal Inlets Research Program (CIRP), a research and development program administered by Headquarters, U.S. Army Corps of Engineers (USACE). The mission of the CIRP is to conduct applied research to improve USACE capability to manage federally maintained inlets, which are present on all coasts of the United States (including the Atlantic, Gulf, Pacific, and the Great Lakes regions). Objectives are to (a) make management of channels - design, maintenance, and operation-more effective to reduce the cost of dredging, and (b) preserve the adjacent beaches in a systems approach that treats the inlet and beach together. To achieve these objectives, CIRP includes work units on short-wave and circulation modeling, navigation channels and adjacent shorelines, inlet scour, laboratory investigations, field investigations, and technology transfer.

This study was performed by Dr. Brian K. Batten, ERDC, CHL, Coastal Engineering Branch (CEB), Evaluation and Design Group (CEERD-HN-CE), and Dr. Nicholas C. Kraus, ERDC, CHL, Senior Scientist Group. Dr. David Yang was the NAN study manager. A portion of the shoreline data for this study was provided by Mr. William G. Grosskopf, Offshore and Coastal Technologies, Inc. (OCTI), and by Dr. Mark R. Byrnes, Applied Coastal Research and Engineering, Inc. Mr. Michael J. Morgan, formally, City University of New York, presently NAN, provided data and discussion of several aspects of this report. This study was performed under the administrative supervision of Dr. Yen-Hsi Chu, former chief, CEB, Dr. William D. Martin, Deputy Director, CHL, and Mr. Thomas W. Richardson, Director, CHL. Ms. J. Holley Messing, CEB, formatted this report. Mr. Morgan and Dr. Andrew Morang, CEB, provided reviews. 
At the time of publication, Dr. James R. Houston was Director of ERDC, and COL James R. Rowan, EN, was Commander and Executive Director. 


\section{Conversion Factors: Non-SI to SI Units of Measurement}

Non-SI units of measurement appearing in this report can be converted to SI units as follows:

\begin{tabular}{||l|l|l||}
\hline \hline Multiply & By & To Obtain \\
\hline \hline acres & $4,046.873$ & square meters \\
\hline cubic feet & 0.02831685 & cubic meters \\
\hline cubic yards & 0.7645549 & cubic meters \\
\hline feet & 0.3048 & meters \\
\hline knots (international) & 0.5144444 & meters per second \\
\hline miles (U.S. statute) & 1.609347 & kilometers \\
\hline square feet & 0.09290304 & square meters \\
\hline
\end{tabular}




\section{Executive Summary}

Congress adopted the Federal navigation project at Mattituck Inlet in 1896. Work on inlet stabilization structures commenced in 1901 and was completed in 1906. Interruption of longshore sediment transport by the navigation project resulted in sediment impoundment updrift of the inlet and sediment deprivation downdrift. For this study, long-term shoreline position data allowed delineation of the updrift and downdrift areas of inlet influence.

Shoreline change analysis and sediment budget formulations were employed to estimate the responsibility of the Federal government for erosion downdrift of Mattituck Inlet. Ideally, shoreline and beach volume change should be evaluated for two distinct periods; one before project construction to determine the natural or background change, and the other after construction to quantify the response of the coast to the project. For Mattituck Inlet, data available prior to the date of construction (1906) had a high degree of error, inherent with the available early survey data (1838 and 1885). Therefore, regional shoreline change trends were determined and compared to the rate of shoreline change in the project area over the lifetime of the project. This approach allowed comparison of shoreline change over contemporary time periods during which coastal processes are similar. For this study, the regional change was calculated between Mt. Sinai Harbor, the western boundary, and Horton Point, the eastern boundary, about 33 miles of shoreline. It was found that for the period 1885 to 2001, the regional shoreline change trend was recession at an average rate of $1.0 \mathrm{ft} / \mathrm{year}$ ( $\pm 0.4 \mathrm{ft} /$ year).

Analysis of long-term shoreline change on the project scale showed that shoreline recession attributable to the inlet extends for approximately $9,600 \mathrm{ft}$ to the east of the inlet. This $9,600-\mathrm{ft}$ zone of influence was divided into a primary impact area extending 4,000 ft east of Mattituck Inlet, with an average recession rate of $1.7 \mathrm{ft} /$ year, and a secondary impact area extending 4,000 to 9,600 ft east of Mattituck Inlet, with an average recession rate of $1.3 \mathrm{ft} /$ year. Residual shoreline change rates, or the change attributable to the Federal navigation project, were then determined by removing the average regional recession rate from the shoreline change rates adjacent to the project. This procedure gave residual recession rates of $0.7 \mathrm{ft} /$ year for the primary erosion area and $0.3 \mathrm{ft} /$ year for the secondary erosion area. The amount of shoreline recession attributable to the Federal navigation project was determined at 41 and 23 percent in the primary and secondary recession areas, respectively, based on shoreline change analysis. 
Volumetric losses were estimated from the shoreline change rates by applying standard coastal engineering relationships. These relationships give volume losses of $147,000 \mathrm{cu}$ yd $( \pm 54,000 \mathrm{cu} \mathrm{yd})$ in the primary erosion area and $88,000 \mathrm{cu}$ yd $( \pm 37,000 \mathrm{cu} \mathrm{yd})$ in the secondary erosion area, for a total loss of $235,000 \mathrm{cu}$ yd over the lifetime of the Federal navigation project. A conclusion of the analysis is that the construction and maintenance of the Federal navigation project at Mattituck Inlet resulted in erosion of 235,000 cu yd ( $\pm 91,000 \mathrm{cu} \mathrm{yd})$ from the $9,600 \mathrm{ft}$ of shoreline downdrift (east) of the inlet.

Volume losses were also evaluated through a sediment budget approach that depends on estimates of potential longshore sediment transport rates. This analysis indicates that the Federal navigation project at Mattituck Inlet caused a 94 percent reduction in average annual longshore sediment transport between 1906 and 1950, and a 58 percent reduction between 1950 and 2004. Total volume loss attributable to the Federal navigation project was estimated at $1,063,000 \mathrm{cu} y d( \pm 238,000 \mathrm{cu} \mathrm{yd})$. This volume includes the volume of material bypassed through placement of dredged material, documented non-Federal sediment mining of the accretion fillet, and offshore losses. These quantities were subtracted from the total volume loss, as they either mitigate sediment losses (dredged material placement), or do not fall under the Federal responsibility for sediment loss to downdrift beaches (non-Federal mining, offshore losses). Therefore, Federal responsibility for sediment volume deprived to downdrift beaches over the lifespan of the Federal navigation project at Mattituck Inlet was estimated at $493,000 \mathrm{cu}$ yd $( \pm 216,000 \mathrm{cu} \mathrm{yd})$.

Three alternatives were explored for mitigation of downdrift erosion associated with the Mattituck Inlet Federal navigation project. The first alternative continues the existing practice of periodic channel maintenance dredging and downdrift placement. This alternative bypasses sediment at an average annual rate of 2,000 $\mathrm{cu} \mathrm{yd} /$ year, $10,000 \mathrm{cu} \mathrm{yd} / \mathrm{year}$ less than the estimated average annual eastward longshore transport rate at the inlet.

The second alternative combines present management practice with annual bypassing of sediment from the updrift fillet to the downdrift area of influence. Bypassing volumes would be equivalent to the rate of updrift sediment impoundment, approximately $7,000 \mathrm{cu}$ yd/year. Material would be removed from the sub-aerial updrift fillet and bypassed by truck. The direct benefit is reduced potential for barrier breaching directly east of the inlet. Increased sediment supply would enhance storm protection and protection of private property along downdrift beaches. Also, shoaling rates in the navigation channel may be reduced.

The third alternative involves larger removals of material from the updrift impoundment fillet, in addition to shoals in the inlet channel, on a less frequent basis. A minimum of approximately $125,000 \mathrm{cu}$ yd is presently available from three identified areas, including the updrift impoundment fillet and sub-aerial portions of the flood shoal. Longshore transport rates into Mattituck Inlet would support such large-scale mining of the impoundment fillet on a 10-year interval; however, shoals within the inlet channel would take a longer time to reform. The volume of bypassed material could be augmented if operations coincide with channel maintenance. Benefits of this alternative include enhanced storm protection, protection of private property along downdrift beaches, significant 
reduction of shoaling rates in the navigation channel, improved navigability, and enhanced circulation in Mattituck Creek. 


\section{Introduction}

This report was prepared for the U.S Army Engineer District, New York, (hereafter, New York District) to evaluate shore erosion in response to construction of the Federal navigation project at Mattituck Inlet, NY, under the authority of Section 111 of the River and Harbor Act of 1968, Public Law 90-483, approved August 1968. The original navigation project was authorized in 1896 and modified in 1935 and 1964.

The report is organized into seven chapters and two appendixes. Chapter 1 gives an introduction to the Section 111 authority and the physical setting at the study site. Chapter 2 discusses shoreline change and change rates in the vicinity of Mattituck Inlet. Shoreline change rates are calculated for the region and compared for shorelines adjacent to the inlet. Chapter 3 describes numerical simulations of waves, wave-induced and tidal currents, and sediment transport pathways at the inlet. Chapter 4 develops the sediment budget for the site and region. Chapter 5 describes estimated future conditions without a project. Chapter 6 evaluates the responsibility of the Federal government for downdrift shore erosion, and Chapter 7 presents alternatives for mitigation. Appendixes A and $\mathrm{B}$ document analysis results for shoreline change.

\section{Authority}

On 3 May 1999, the New York State Department of Environmental Conservation (NYSDEC) requested the U.S. Army Corps of Engineers (USACE) to initiate a Section 111 study to investigate shore erosion downdrift of Mattituck Inlet, NY. The objective of this study is to determine the degree to which the jetties stabilizing the Federal navigation project and channel operation and maintenance are responsible for erosion downdrift of the inlet. The downdrift barrier beach at Mattituck Creek has narrowed and, in the past, was subject to breaching. If no action were taken, beaching could occur due to continued shore erosion combined with surge and storm wave action. Reoccurrence of a breach would cause severe navigation and economic dislocations. An Initial Appraisal Report was completed in Fall 2001, and the Project Management Plan was negotiated with the New York State Department of Environmental Conservation (NYSDEC) as the non-Federal sponsor. The Feasibility Cost Sharing Agreement (FSCA) was executed in June 2003.

Section 111 of the River and Harbor Act of 1968, as amended, states the following: 
"The Secretary of the Army is authorized to investigate, study, plan, and implement structural and nonstructural measures for the prevention or mitigation of shore damages attributable to Federal navigation works and shore damage attributable to the Atlantic Intracoastal Waterway and the Gulf Intracoastal Waterway, if a non-Federal public body agrees to operate and maintain such measures, and, in the cases of interests in real property acquired in conjunction with nonstructural measures, to operate and maintain the property for public purposes in accordance with regulations prescribed by the Secretary. The cost of implementing measures under this section shall be cost-shared in the same proportion as the cost-sharing provisions applicable to the project causing the shore damage. No such project shall be initiated without specific authorization by Congress if the Federal first cost exceeds $\$ 5,000,000$."

\section{Purpose and Scope of Study}

The purpose of this feasibility study is to analyze the response of the adjacent shorelines to the Federal navigation project at Mattituck Inlet, NY, assess impacts, and investigate plans for the mitigation of shore damage attributable to the project.

Ideally, shoreline and beach volume change should be evaluated in two distinct periods, one representing conditions before project construction to determine the natural or background change, and the other representing conditions after construction to quantify the response of the coast to the project. For Mattituck Inlet, data available prior to the date of construction (1906) had a high degree of error inherent with the available early survey data (1838). Therefore, shoreline change was evaluated on a regional scale for the lifetime of the Federal navigation project. Regional background recession rates were then compared to the rate of shoreline change in the project area to determine the impact of the Federal navigation project. This approach allows evaluation of shoreline changes adjacent to the inlet for contemporary time periods during which coastal processes are similar.

Technology developed in the Coastal Inlets Research Program (CIRP) administered by Headquarters, USACE, was applied in this study, both in direct application and through adaptation of predictive models and information generated in a contemporaneous CIRP study for Mattituck Inlet and an adjacent non-Federal inlet (Morgan et al. 2005).

\section{Site Conditions}

Mattituck Inlet is located on the Long Island Sound coast of the eastern north fork of Long Island, in the town of Southold, NY (Figure 1). The inlet provides an entrance to Mattituck Creek, the only available harbor on the north shore of Long Island between Port Jefferson to the west and Greenport Harbor to the east, a distance of approximately 52 nautical miles ${ }^{1}$ (Figure 2). Figure 3 shows the full extent of Mattituck Creek.

\footnotetext{
1 This document involves analysis of historic and recent engineering documents and data with values reported in American customary (non-SI) units. Units of measurement reported in previous publications are retained. A table of factors for converting non-SI units of measurements to SI units is presented on page xi.
} 


\section{Geologic setting}

Geomorphology. Long Island lies in the Coastal Plain province of the eastern seaboard of the United States. The island is an east-northeast extension of New York state, separated from New York City by the East River and extending parallel to the Connecticut coast. Long Island is composed of relict glacial moraine outwash and Pleistocene era sediment (Taney 1961). The island was formed by deposition of two terminal moraines of the Wisconsin glacier in the Late Pleistocene, the Harbor Hill and Ronkonkoma. On western Long Island, the Ronkonkoma Moraine overlies the younger Harbor Hill Moraine. Towards the east, the moraines separate with the Harbor Hill Moraine extending northeast to Orient Point and the Ronkonkoma extending east to Montauk Point.

The proximity of the north shore to the Harbor Hill Moraine results in a steep ambient gradient, creating a coast characterized by bluffs and a steep shoreface. The eastern north shore of Long Island consists of shallow embayments separated by headland points. Mattituck Creek lies in a north draining coastal plain valley, with bluff heights tapering towards the inlet from both the east and west.

Beach sediment is composed of poorly sorted glacial outwash, with grain size ranging from medium to coarse sand to pebbles, cobbles, and boulders. Repeated site visits have shown that sediment to the east of the inlet is coarser than sediment to the west. Coarser sediment on the east side is expected, because the east beach has experienced erosion due to sediment trapping updrift of the west jetty. Erosion, coupled with deprivation of new, finer material from longshore transport has left a coarser lag deposit along the east beach.

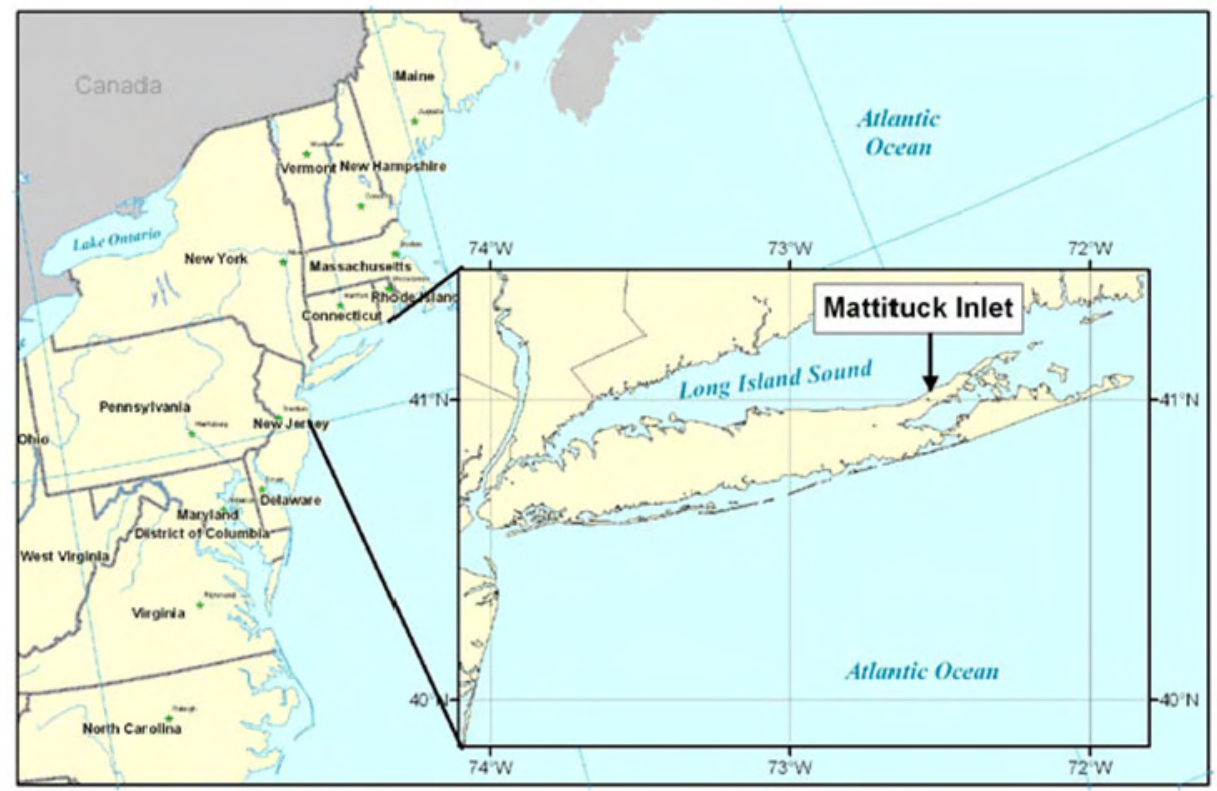

Figure 1. Location map for Mattituck Inlet, north shore of Long Island, NY 


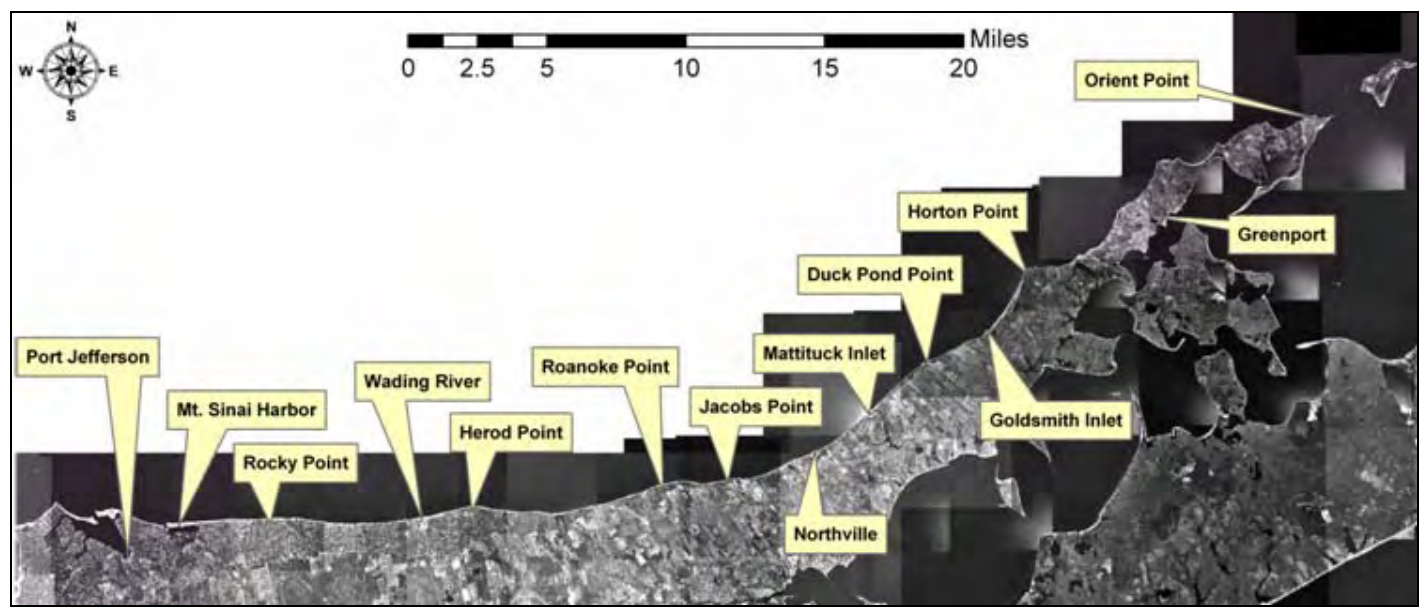

Figure 2. Eastern north shore of Long Island, NY

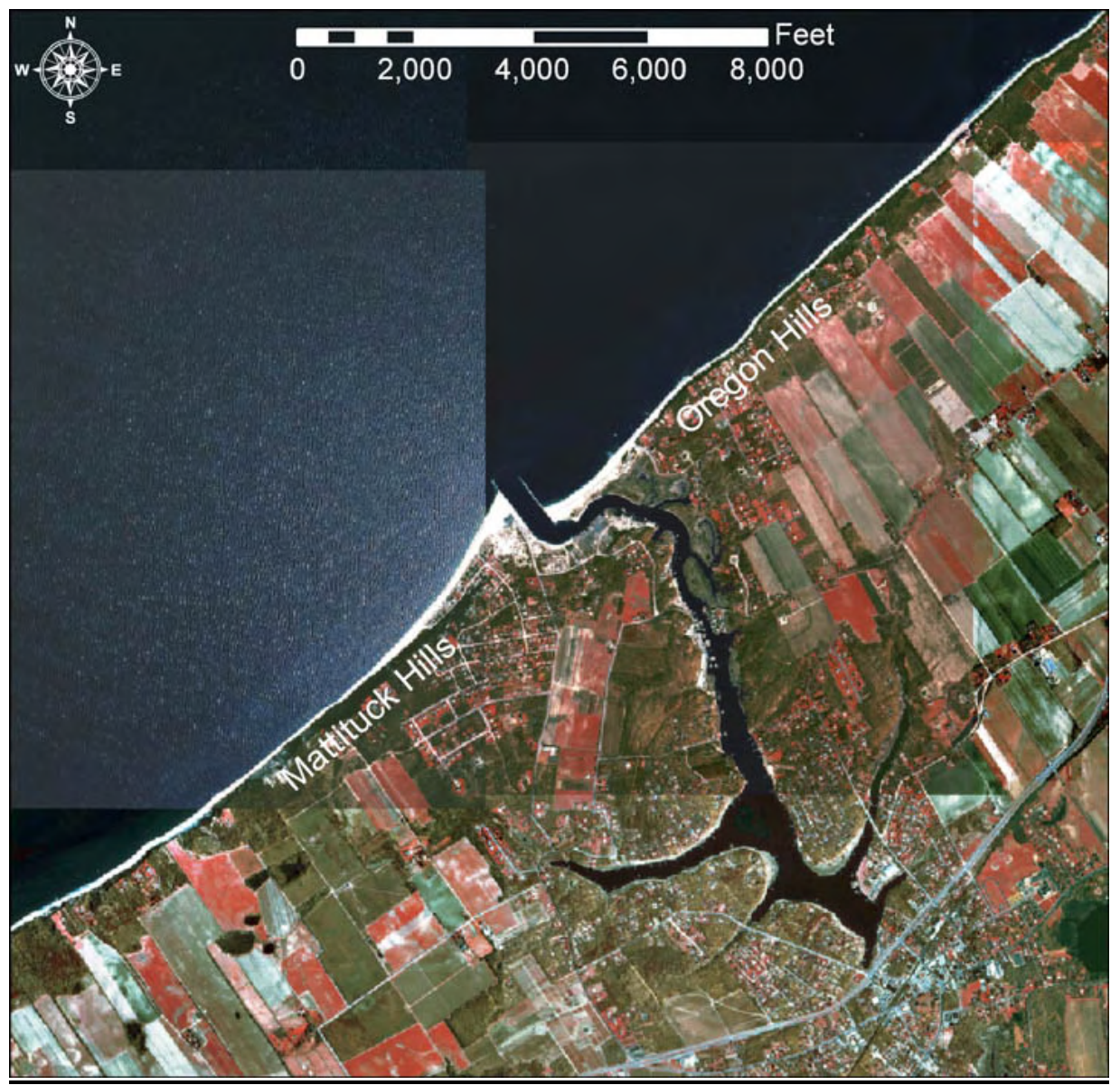

Figure 3. Mattituck Inlet and Creek, 1999 
Tide. The astronomical tide within Long Island Sound is semidiurnal. Tidal range increases from east to west within the basin. Mattituck Inlet has a mean tidal range of $5.2 \mathrm{ft}$, with a spring range of $6.0 \mathrm{ft}$ (National Ocean Service (NOS) 2002). Morgan et al. (2005) calculated a tidal prism of $4.32 \times 10^{7} \mathrm{cu} f t$ for the inlet.

Wind. Wind information for the study area is based on the statistics of the approximate 30-year record at Bridgeport, CT, located 20 miles northwest of the project site. An annual wind rose diagram showing the percentage occurrence of wind speed vs. direction is shown in Figure 4. The wind rose diagram indicates that the majority of the winds are from SW to NW quadrant (approximately 34 and 28 percent, respectively), with average wind speed in the range of 10 to $20 \mathrm{mph}$. Wind from the NE quadrant occurs approximately 21 percent of the time. The available wind information indicates that wave-induced net longshore sediment transport is directed to the east.

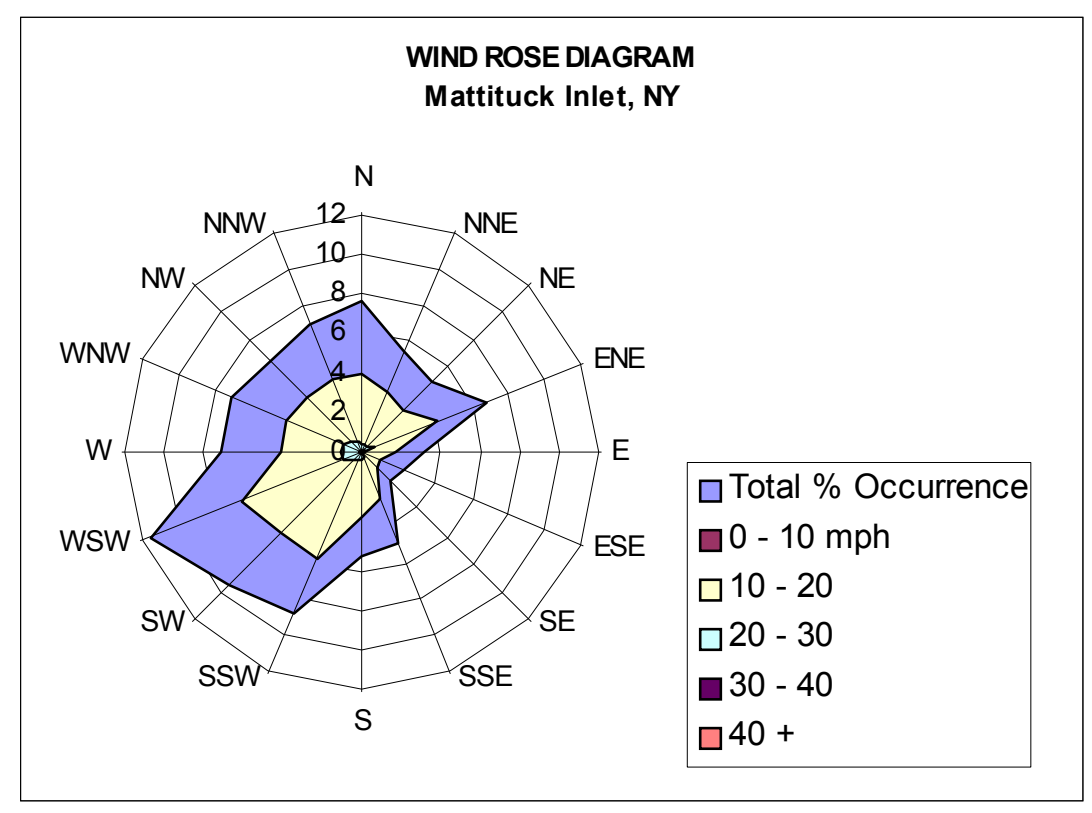

Figure 4. Wind rose diagram for Mattituck Inlet, NY

Waves. Wave height and period information is available for Long Island Sound between January 1995 and January 1998 (data prepared for the New York District by Offshore Coastal Technologies, Inc., OCTI). The average and maximum significant wave height and period for each year are reported in Table 1. The average significant wave height and period during the 4-year interval was $0.8 \mathrm{ft}$ and $2.9 \mathrm{sec}$. Representative peak significant wave height and period during a storm were $5.4 \mathrm{ft}$ and $4.9 \mathrm{sec}$, respectively. 


\begin{tabular}{|c|c|c|c|c|}
\hline \multicolumn{5}{|c|}{$\begin{array}{l}\text { Table } 1 \\
\text { Average Significant Wave Height and Period }{ }^{1}\end{array}$} \\
\hline & 1995 & 1996 & 1997 & 1998 \\
\hline $\mathrm{H}, \mathrm{ft}$ & 0.8 & 0.8 & 0.8 & 0.8 \\
\hline$T$, sec & 3.0 & 2.7 & 3.1 & 2.8 \\
\hline$H_{\max }, \mathrm{ft}$ & 5.4 & 4.5 & 4.2 & 3.8 \\
\hline$T_{\max }, \sec$ & 4.9 & 4.7 & 5.1 & 4.5 \\
\hline
\end{tabular}

A wave analysis performed by the New York District (1999) ${ }^{1}$ calculated significant wave heights and wave periods for various long-term return periods for waves approaching Mattituck Inlet (Table 2). The calculated wave heights listed are for extreme weather. Calculated wave directions were from 260 to 280 deg at 10 -deg intervals. Wave height and period for the 10- through 200-year storms have a limited spread because of the restricted fetch of Long Island Sound.

The greater fetch to the west of the study site combined with more northwesterly winds produce a predominant easterly direction of longshore sediment transport. This dominant transport direction is verified by impoundment of material on the west side of shoreline protection structures (New York District 1969; Davies 1972; Omholt 1974; Leatherman et al. 1997). Directional wave data are unavailable for Long Island Sound.

\begin{tabular}{|c|c|c|}
\hline \multicolumn{3}{|c|}{$\begin{array}{l}\text { Table } 2 \\
\text { Calculated Significant Wave Height and Period (New York } \\
\text { District 1999) }\end{array}$} \\
\hline Return Period (year) & Significant Wave Height (ft) & Period (sec) \\
\hline 10 & 12.3 & 6.9 \\
\hline 25 & 13.7 & 7.3 \\
\hline 50 & 15 & 7.6 \\
\hline 100 & 16.4 & 7.9 \\
\hline 200 & 17.4 & 8.2 \\
\hline
\end{tabular}

Current. The current at the inlet is predominantly tidal. Morgan et al. (2005) measured a maximum current velocity of $0.43 \mathrm{~m} / \mathrm{sec}(0.84$ knots $)$ in the inlet channel. Tidal current calculations presented in Chapter 3 and in Morgan et al. (2005) indicate the maximum tidal current through the inlet rarely exceeds $0.5 \mathrm{~m} / \mathrm{sec}$. Based on the Tidal Current Table published by the NOS at a tidal

\footnotetext{
${ }^{1}$ U.S. Army Engineer District, New York. (1999). "Mattituck Inlet, New York," unpublished memorandum.
} 
current station located 1 mile northwest of Mattituck Inlet, the maximum nearshore flood current speed is 0.9 knots northwest and the maximum nearshore ebb current speed is 1.0 knots northeast. Measured current speeds inside the channel range from 0.8 to 1.0 knots (Morgan et al. 2005).

Datums. Relative vertical elevation differences between tidal and geodetic datums were unavailable for the historic NOS tide station at Mattituck Inlet (8512668). The NOS has designated the Bridgeport, CT, tide station (8467150) as the reference station for Long Island Sound. Published conversion factors were consulted to establish the relative difference between the North American Vertical Datum of 1988 (NAVD 1929) and established tidal datums (NOS 2002). The orthometric height conversion between NAVD 88 and the National Geodetic Vertical Datum of 1929 (NGVD 1929) was calculated using the National Geodetic Survey (NGS) VERTCON software application (NGS 1994). Relative differences between relevant tidal and geodetic datums in the 1983 to 2001 tidal epoch are presented in Table 3.

\begin{tabular}{|c|c|}
\hline \multicolumn{2}{|c|}{$\begin{array}{l}\text { Table } 3 \\
\text { Relative Differences Between Tidal and Geodetic } \\
\text { Datums, Mattituck, NY }{ }^{1}\end{array}$} \\
\hline Datum & Elevation, $\mathrm{ft}$ \\
\hline mhw (mean high water) & 2.43 \\
\hline NAVD 88 & 0.0 \\
\hline NGVD 29 & -0.94 \\
\hline mlw (mean low water) & -2.73 \\
\hline mllw (mean lower low water) & -2.96 \\
\hline
\end{tabular}

\section{Existing condition}

Two rubble-mound jetties were constructed at Mattituck Inlet in 1906 to stabilize the navigation channel and support local commercial and recreational use (Ralston 1929). Littoral transport was disrupted as a response to construction of the jetties and maintenance of the channel. Sediment impoundment updrift of the inlet deprived downdrift beaches of material, causing increased rates of shoreline recession east of the inlet. A large, low-lying beach is present west of the inlet, fronting two rows of residential housing and a town park (Figure 5). To the east, a short barrier spit separates Mattituck Creek from Long Island Sound for about $1,000 \mathrm{ft}$, where the creek turns to the south. Barrier width for this extent ranges from 400 to $450 \mathrm{ft}$. A narrow low-lying beach flanked by a large well-vegetated dune field characterizes the downdrift beach (Figure 6). Dune elevation decreases towards the inlet, tapering from high bluffs to the elevation of the east jetty crown along the barrier spit. 


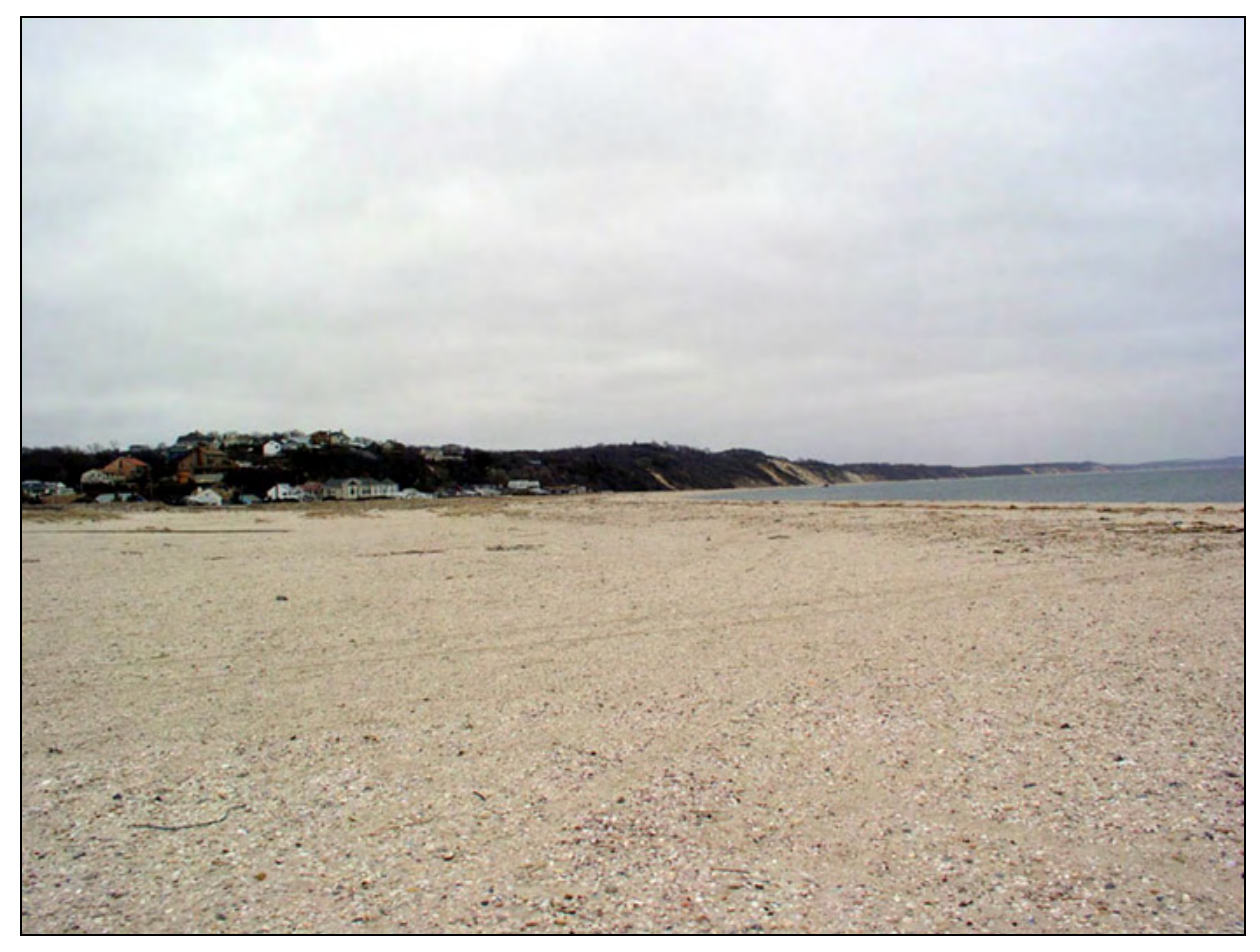

Figure 5. Looking westward from west jetty at Mattituck Inlet, March 2004

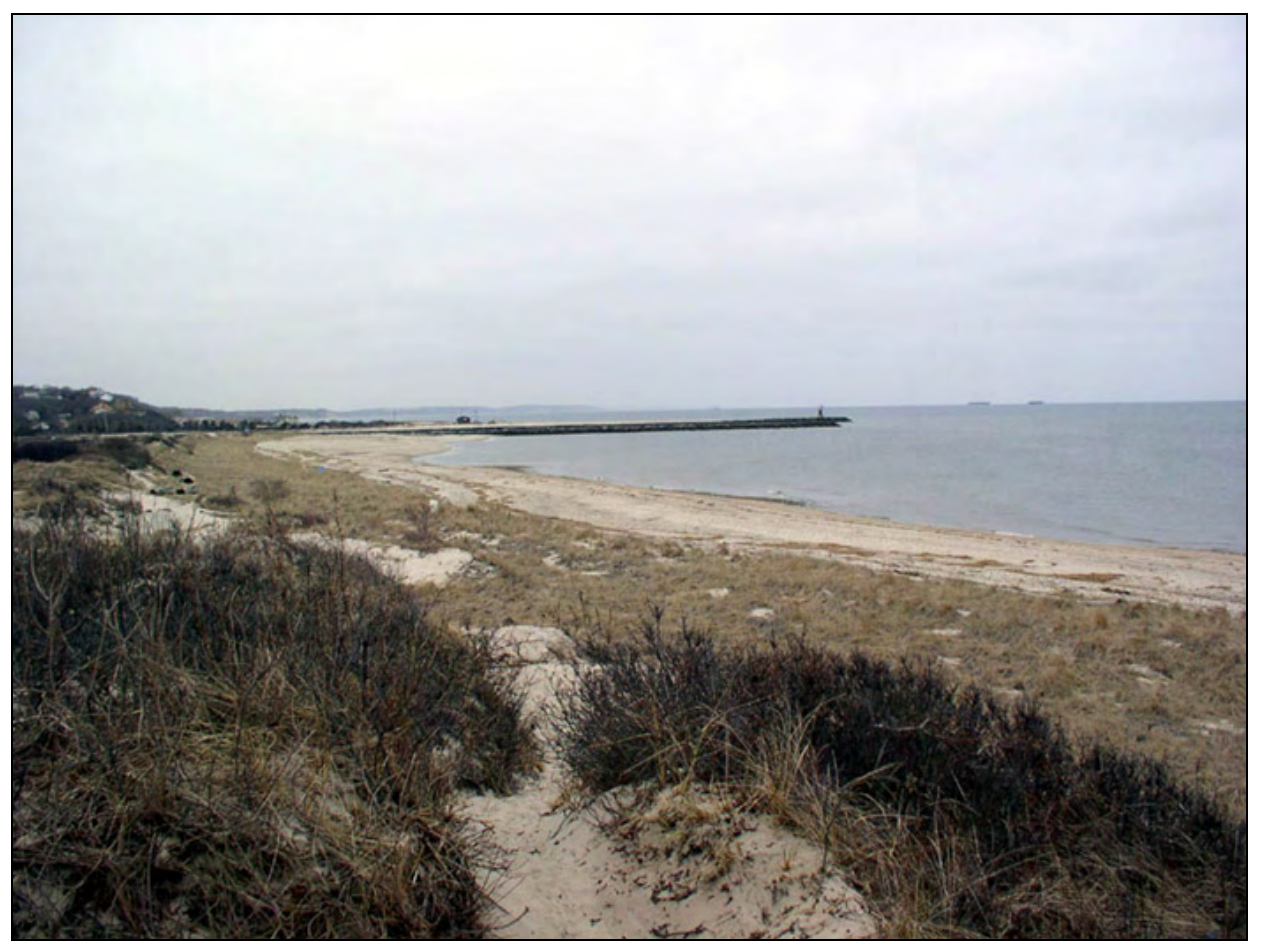

Figure 6. View of coastline east (downdrift) of Mattituck Inlet, March 2004 


\section{Inlet History}

Investigation for a Federal navigation channel at Mattituck Inlet began in the 1880s. By 1890, the establishment of a Federal channel at Mattituck Inlet was recommended. The Federal navigation project at Mattituck Inlet was adopted under the authority of the River and Harbor Act of 1896, and work commenced in 1901. The project called for establishment of a navigable channel at $7 \mathrm{ft} \mathrm{mlw}$ for approximately 1 mile upstream to a tidal mill dam (now Old Mill Road), and an additional 1-1/4 mile section from the mill dam to the village of Mattituck, dredged to $7 \mathrm{ft}$ mhw. By 1906, construction of two parallel jetties at the channel entrance was complete. The rubble-mound jetties were constructed $400 \mathrm{ft}$ apart to the 9-ft contour, with the east jetty $775 \mathrm{ft}$ long and a shorter west jetty at $680 \mathrm{ft}$ at a height of $7 \mathrm{ft} \mathrm{mlw}$. Dredging of the Federal navigation channel was completed in 1914. The west jetty quickly impounded, allowing material to shoal the channel thereafter. The earliest maintenance dredging was performed in 1921 and again in 1923 (Ralston 1929). The disposal area for this dredging is not known. Material was likely disposed offshore, to the east of the inlet.

In response to shoaling in the channel and high maintenance costs, a study was initiated at Mattituck Inlet under the River and Harbor Act of 1925. Shoaling in the channel continued to be a problem at the inlet through the late 1920s and 1930s. An inspection conducted in June 1926 showed the channel entrance to be non-navigable except at high water (Ralston 1929). Studies indicated that sand and gravel were driven around and over the west jetty during storms from the northwest. Annual shoaling rates were estimated between 8,000 and 9,000 cu yd. On average, project depth in the channel entrance lasted less than a year after dredging. It was concluded that the west jetty should be extended to the 12-ft depth contour (approximately $350 \mathrm{ft}$ ) to reduce shoaling in the channel entrance.

The River and Harbor Act of 1935 authorized the extension of the west jetty, and, in 1938, the west jetty was extended $250 \mathrm{ft}$ seaward (Smith 1988).

Recession of the east beach resulted in a landward breach of the barrier adjacent to the east jetty circa 1935 . In response, the east jetty was repaired and extended $280 \mathrm{ft}$ landward in 1946. Subsequent maintenance has been limited to repairs to both jetties in 1975 (Smith 1988) and repairs and a 1-ft increase in elevation of the seaward $100 \mathrm{ft}$ for the west jetty in 1996 (Morgan et al. 2005). The present lengths of the east and west jetties are approximately 1,020 and 1,320 ft, respectively, as measured from 2001 digital orthophotography.

\section{Dredging and Sand Mining History}

Maintenance dredging was initiated in June 1921 at Mattituck Inlet. Ralston (1929) indicates that shoreline response updrift of the inlet was rapid, as the west fillet quickly filled, and sediment began migrating into the inlet. Shoaling continued through the 1930s (Figure 7) and 1940s until authorization was granted for extension of the west jetty. After lengthening of the west jetty, dredging frequency and volume decreased (Table 4). In total, approximately 391,000 cu yd of sediment was dredged from Mattituck Inlet between 1921 and 2004. Condition surveys for the 1946, 1950, 1955, and 1965 dredging show that dredged material was placed either on the subaerial beach or below the waterline 
directly to the east of the inlet. Records indicate that, after these initial placements on the beach or in the nearshore, disposal of maintenance dredged sediment on the eastern beach became standard practice. Shoreline change data are investigated for evidence supporting this disposal procedure in Chapter 2.

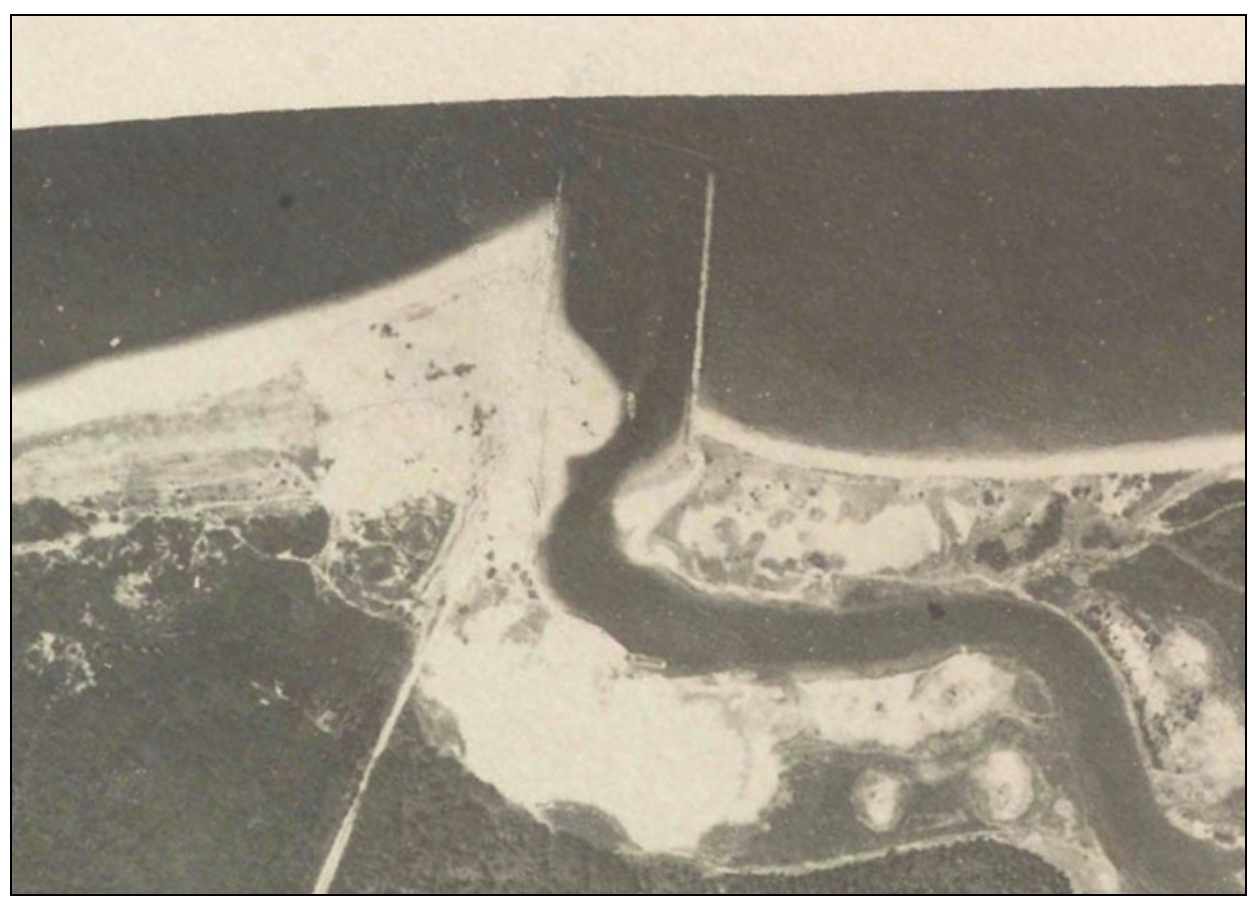

Figure 7. Sediment shoaling in Mattituck Inlet, circa 1930

The New York District issued permits for commercial sand and gravel mining within the footprint of the Federal channel beginning in the 1920s and ending in the 1940s, according to available records. The New York District recognized that commercial mining would reduce Federal channel maintenance requirements. Eleven permits (including extensions) were granted between 1925 and 1937 to commercial mining interests, 10 of these for removal of sand and gravel from the channel entrance (Table 5). It is difficult to evaluate the volume of material removed through this mining. The majority of permits recorded partial completion of the work. Only one permit confirmed completion. A letter from the Mattituck Chamber of Commerce in 1933 reported to the New York District that the work was incomplete, and equipment was abandoned at the site. The letter, dated 11 May 1933, also notes "any dredging done in the Creek is of no assistance to navigation because without the proper breakwater (jetty) it immediately fills in.” 


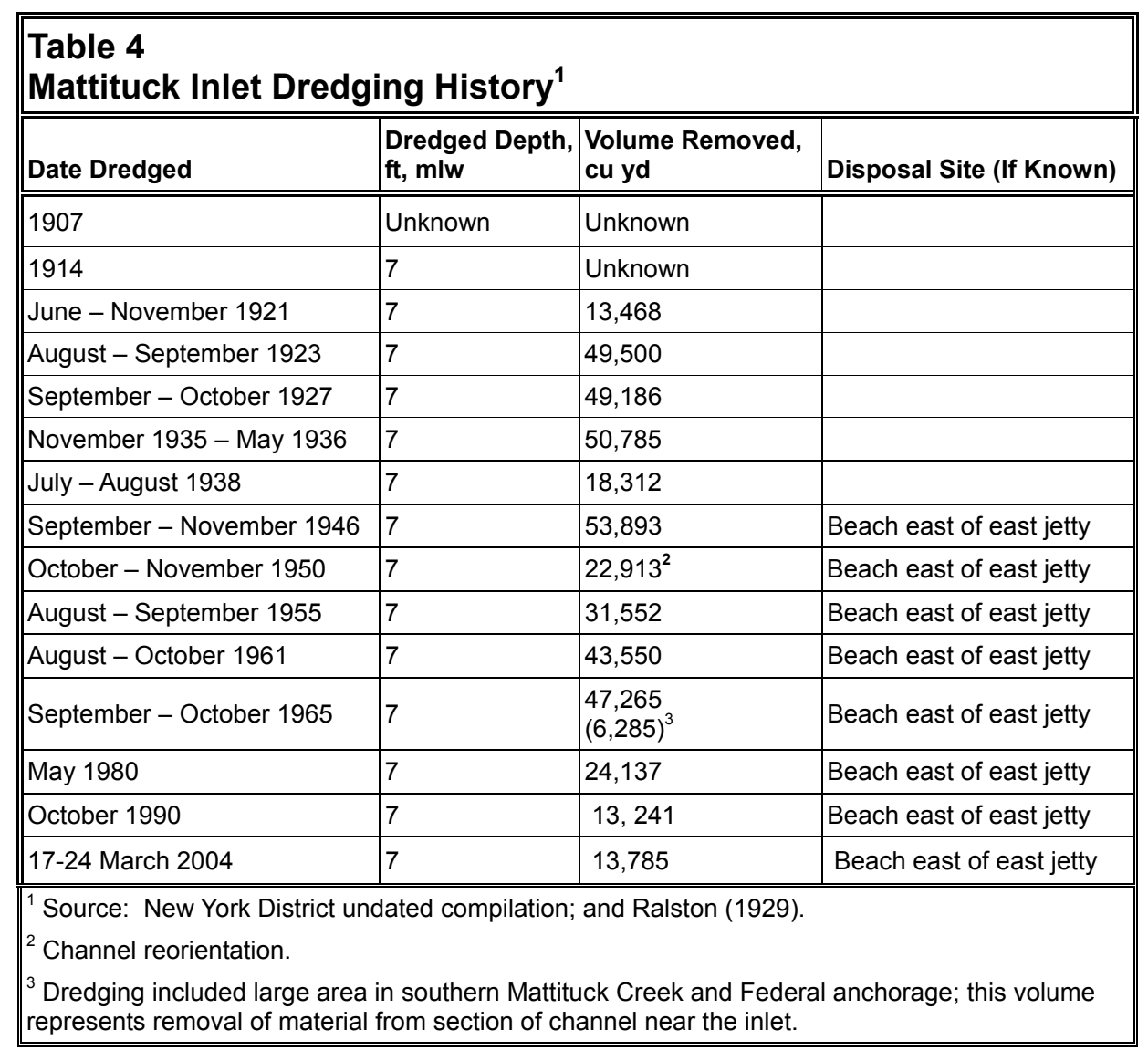

\begin{tabular}{|c|c|c|c|c|c|}
\hline \multicolumn{6}{|c|}{$\begin{array}{l}\text { Table } 5 \\
\text { Summary of Available Federal Commercial Sand Mining Permits from } \\
\text { New York District Archive }\end{array}$} \\
\hline Applicant & Location & $\begin{array}{l}\text { Depth, ft } \\
\text { (mlw) }\end{array}$ & $\begin{array}{l}\text { Date } \\
\text { Granted }\end{array}$ & \begin{tabular}{|l} 
Date \\
Expired
\end{tabular} & $\begin{array}{l}\text { Work } \\
\text { Completed }\end{array}$ \\
\hline J. H. Rambo & Channel Entrance & 10 & $4 / 9 / 1925$ & $12 / 31 / 1928$ & None \\
\hline Northport Sand and Gravel & S.W. Flood Shoal & 10 & 9/1/1925 & $12 / 31 / 1928$ & None \\
\hline J. H. Rambo & Channel Entrance & 10 & $1 / 29 / 1929$ & 12/31/1932 & Partial \\
\hline C. H. Benjamin & Channel Entrance & 12 & $2 / 10 / 1928$ & $12 / 31 / 1934^{1}$ & Partial \\
\hline F. M. Lewis & Channel Entrance & 12 & $6 / 16 / 1928$ & $12 / 31 / 1931$ & Yes \\
\hline Seely \& Walsh & W. Channel Entrance & 20 & 9/8/1931 & 12/31/1934 & None \\
\hline Bickel \& Wichert Dredging & Channel Entrance & 20 & $8 / 19 / 1932$ & $12 / 31 / 1933$ & Partial \\
\hline Bickel \& Wichert Dredging & Channel Entrance & 20 & $6 / 30 / 1934^{2}$ & Unknown & Unknown \\
\hline Seaboard Sand and Gravel & Unknown & Unknown & Unknown & Unknown & Unknown \\
\hline J. Cancro & Channel Entrance & 20 & $6 / 30 / 1933$ & 12/31/1936 & Partial \\
\hline J. Cancro & Channel Entrance & 20 & $2 / 25 / 1937^{2}$ & $12 / 31 / 1943$ & None \\
\hline
\end{tabular}


Site inspections were conducted only for later permits and document that little to no work was completed. Although partial completion of work makes it difficult to estimate the volume of material removed, the permits confirm full impoundment of the updrift jetty and mass movement of material into the inlet channel. Ralston (1929) cited federally permitted sand and gravel mining as a commercial activity at Mattituck Inlet, estimating removal of material at $50 \mathrm{cu} \mathrm{yd}$ /day from the channel entrance area for the manufacturing of concrete tile. If mining operations occurred approximately 200 days/year, this rate amounts to removal of $10,000 \mathrm{cu}$ yd/year. Assuming that partially completed permits finished approximately half of their work, this rate would give an estimated total of 85,000 cu yd from Federal permits listed in Table 5.

The permit record does not appear to fully document all mining activities at Mattituck Inlet. The names of several mining companies appear on Federal condition surveys of the entrance and channel after the last documented Federal mining permit expired in 1943 . The 1965 condition survey shows two companies, Gotham Sand and Gravel, and Asphalts, Inc. Later, in 1971, the New Sand and Gravel Company appeared on condition survey maps. Processing facilities were established by 1955 (aerial photograph). No records were available to assess the volume of material removed by these operations. Removal of material from shoal areas in and around the bend of the channel is observed within the aerial photographic record and may be attributed to these mining operations. It is estimated that these facilities were removing 10,000 to $25,000 \mathrm{cu} \mathrm{yd} /$ year of material from the channel, resulting in a total volume of 200,000 to $500,000 \mathrm{cu}$ yd.

In addition to mining operations in the inlet channel and entrance, material was also mined from the impoundment fillet west of Mattituck Inlet. Records of the amount of removal are only available between 1960 and 1975, listed in Table 6. During this period, the Mattituck Park District was selling material from the impoundment fillet to finance improvements in the park. Volume estimates were made from income generated from this mining (Schubel 1976; Allee et al. 1995). Sand mining was reported along the beach fronting the parking lot at the town park; however, it is difficult to concede that volumes of $25,000 \mathrm{cu}$ yd/year were removed from such a small area.

To satisfy an annual mining volume of $25,000 \mathrm{cu}$ yd, an area of approximately $135,000 \mathrm{sq} \mathrm{ft}$ ( 3 acres) would be required, assuming a berm height of $5 \mathrm{ft}$, and removal of material landward of the waterline. Thus, sand mining likely occurred along most of the length of the accretion fillet. The large volumes of sediment removed from the updrift fillet are consistent with the decrease in dredging frequency from 1965 to 1980 (Table 4). In total, a reported $243,000 \mathrm{cu}$ yd (on average, $16,000 \mathrm{cu}$ yd/year) of material was removed from the updrift fillet. It is not feasible to verify mining volumes prior to documented mining. Mining probably began between 1947 and 1955, as observed from change in the impoundment area determined from aerial photographs (Chapter 3 ). It is possible that mining activities began as early as 10 years prior to the documented volumes. Given this time frame and the documented rate of removal, it is estimated that undocumented mining removed between 20,000 and $160,000 \mathrm{cu}$ yd of material from the impoundment fillet. 


\begin{tabular}{|l|c||}
\hline \multicolumn{2}{|l||}{$\begin{array}{l}\text { Table } 6 \\
\text { History of Sand Mining from Impoundment Fillet }{ }^{1}\end{array}$} \\
\hline \hline Year & Volume, cu yd \\
\hline \hline 1960 & 22,200 \\
\hline 1961 & 17,700 \\
\hline 1962 & 14,700 \\
\hline 1963 & 36,100 \\
\hline 1964 & 20,000 \\
\hline 1965 & 26,500 \\
\hline 1966 & 25,800 \\
\hline 1967 & 24,900 \\
\hline 1968 & 15,900 \\
\hline 1969 & 6,500 \\
\hline 1970 & 7,200 \\
\hline 1971 & 8,500 \\
\hline 1972 & 9,500 \\
\hline 1973 & 3,400 \\
\hline 1974 & 400 \\
\hline 1975 & 4,000 \\
\hline \hline Total: & 243,300 \\
\hline 1 Source: Schubel $(1976)$ \\
\hline
\end{tabular}




\section{Shoreline Change Analysis}

Shoreline change rates were calculated for both regional and project study areas. Regional shoreline change rates (Mt. Sinai to Horton Point) were determined from three surveys of shorelines performed between 1885 and 2001, spanning 116 years. Shoreline change rates in the local project study area (Jacobs Hill to Duck Pond Point) were calculated from 14 shoreline surveys made between 1838 and 2004. Regional rates were established to gain understanding into coastal processes and to provide comparative background erosion rates to evaluate shoreline change adjacent to Mattituck Inlet. Ideally, a preexisting condition would be compared to postconstruction conditions to evaluate the response of adjacent shorelines and sediment budget to the introduction or stabilization of an inlet (Rosati and Kraus 1999a). For the Mattituck Inlet area, preexisting data sources are sparse and not recommended for qualitative shoreline analysis (Crowell et al. 1991).

A regional approach is expected to produce reliable shoreline change rates throughout the entire study period. In addition, factors controlling shoreline evolution change through time, such as storm frequency and sediment supply. Coastal processes in the 1800s may or may not be representative of those in the 1900s. Comparison of shoreline evolution in the proximity of the inlet to the region through time allows for a representative assessment of the impact of the Federal navigation project at Mattituck Inlet on the adjacent shorelines.

\section{Previous Studies}

The first comprehensive shoreline change study for the north shore of Long Island was completed by the New York District (1969). The study considered only the Suffolk County portion of the north shore, and it investigated shoreline change between 1836-1838, 1885-1886, and 1965. Data indicated erosion as the dominant process (approximately $2 \mathrm{ft} /$ year) with localized areas of accretion. As much as $280 \mathrm{ft}$ of recession was observed in the Mattituck Hills area between 1836-1838 and 1885-1886. Mattituck Inlet shifted $600 \mathrm{ft}$ to the west during this period, with the updrift shoreline (west) advancing as much as $230 \mathrm{ft}$, and the downdrift shoreline advancing as much as $600 \mathrm{ft}$ (1,500 ft of shore east of inlet) (New York District 1969). Shoreline change trends for the study period (18361838 and 1965) indicate accretion updrift of the inlet and erosion downdrift. The shoreline advanced as much as $780 \mathrm{ft}(6 \mathrm{ft} /$ year) for a 1,700 ft reach west of Mattituck Inlet. The 3,500 ft of shoreline to the east receded as much as $380 \mathrm{ft}$ 
( $3 \mathrm{ft} /$ year), though the shoreline adjacent to the east jetty advanced $380 \mathrm{ft}$ (New York District 1969).

The National Shoreline Study (USACE 1971) conducted regional analysis of shoreline condition, use, and ownership. For the eastern north shore of Long Island (Suffolk County), the study determined average recession rates between 1 to $2 \mathrm{ft} /$ year for the period 1836 to 1965 . The reach from Miller Place (just east of Mt. Sinai, Figure 2) to Mattituck Inlet experienced slightly higher rates of about $2 \mathrm{ft} /$ year. Severe recession was noted in the Mattituck Hills area (approximately 1 mile updrift of the inlet) with rates reaching $3.5 \mathrm{ft} /$ year. The entire shoreline east of Mt. Sinai Harbor to Orient Point was classified as a "critical" erosion area (USACE 1971). The study catalogued 236 groins, 14 jetties, and about 46,500 ft of seawalls, revetments, bulkheads, and sand fill within Suffolk County.

Bartholomew and McGuinness (1972) reviewed data from the 1971 National Shoreline Study and reclassified areas of shoreline recession based on time frames of property endangerment. The north shore of Suffolk County, including the study area, was classified as "areas where continued critical erosion is likely to endanger property, scarce wildlife habitats, or landmarks of historical or natural significance within 5 years."

Davies (1972) and Davies et al. (1973) calculated shoreline recession (high-water line) for the Suffolk County Long Island Sound shoreline between 1885 and 1965. Shoreline change rates were calculated between stations along the shore, and then averaged. For the shoreline east of Port Jefferson, shoreline recession was the predominant trend, with shoreline change rates ranging from 0.2 to $3.7 \mathrm{ft} /$ year. The shoreline updrift of Mattituck Inlet had the highest accretion rate in this area at $3.2 \mathrm{ft} /$ year (Davies et al. 1973). Downdrift of the inlet, the shoreline receded at a rate of 0.3 to $1.2 \mathrm{ft} /$ year. A portion of the shoreline directly downdrift of the inlet was averaged with the updrift shoreline, and this likely reduced the apparent magnitude of downdrift erosion.

The Long Island Sound Regional Study (New England River Basins Commission 1975) interpreted data compiled from the National Shoreline Study to identify areas of high erosion damage and develop long-term mitigation plans. Coastal losses in the study area were estimated at 15 acres/year, with annual damages in response to shore erosion estimated at 1.3 million dollars (1970 dollars). Annual damages for 1990 and 2020 were estimated at 2 and 4 million dollars, respectively.

Fields et al. (1999) prepared the most comprehensive study of shoreline change available within the study area to that date. Historical shoreline change was evaluated from nine shoreline surveys from 1885 to 1998 for the Town of Southhold, NY. Results of their study will not be discussed here, as data sources employed in their study are reanalyzed and augmented herein.

\section{Shoreline Definition}

In the simplest description, a shoreline is defined as the boundary where a body of water comes in contact with dry land. Changing conditions in the marine and terrestrial environments modify the position of the shoreline in time spans from seconds to decades, resulting in numerous fluctuations of the shoreline 
position from inches to hundreds of feet. To accurately compare successive shoreline positions at a site, a consistent shoreline definition must be established (Kraus and Rosati 1997). For this study, the analyzed shoreline is the high-water line (hwl).

The hwl is defined as "the intersection of land with the water surface at an elevation of high water," which can be interpreted by a continuous line of deposition of debris on the foreshore (NOAA 2000). The hwl is an interpreted shoreline, as opposed to the mean high water line ( $\mathrm{mhwl}$ ), which is determined through the measurement and analysis of water levels at a site (Kraus and Rosati 1997). The hwl is the most commonly used shoreline indicator in the United States because of ease of interpretation in the field and on aerial photography (Leatherman 2003). Early NOS topographic sheets (T-sheets) identified the shoreline as the hwl, as described by Shalowitz (1964):

"From the standpoint of the surveyor, the high-water line is the only line of contact between land and water that is identifiable on the ground at all times and does not require the topographer being there at a specified time during the tidal cycle, or the running of levels. The high-water line can generally be closely approximated by noting the vegetation, driftwood, discoloration of rocks, or other visible signs of high tides. The mean high-water line must not be confused with the storm high-water line, which is usually marked by driftwood and the edge of considerable vegetation."

The hwl is identified in aerial photographs through the same method. At times, this definition becomes problematic if interpreting historical aerial photographs, which are sometimes of poor quality, either under or overexposed, resulting in a washing out of the sub-aerial beach. Specialized experience and manipulation of the digital image are employed to identify these features and create an accurate representation of the shoreline. Modern aerial photography and orthophotographs are of much higher resolution and allow distinction of the hwl with less manipulation of the digital data. The hwl signature appears to the right of Figure 8, taken in March 2004 along the coast east of Mattituck Inlet.

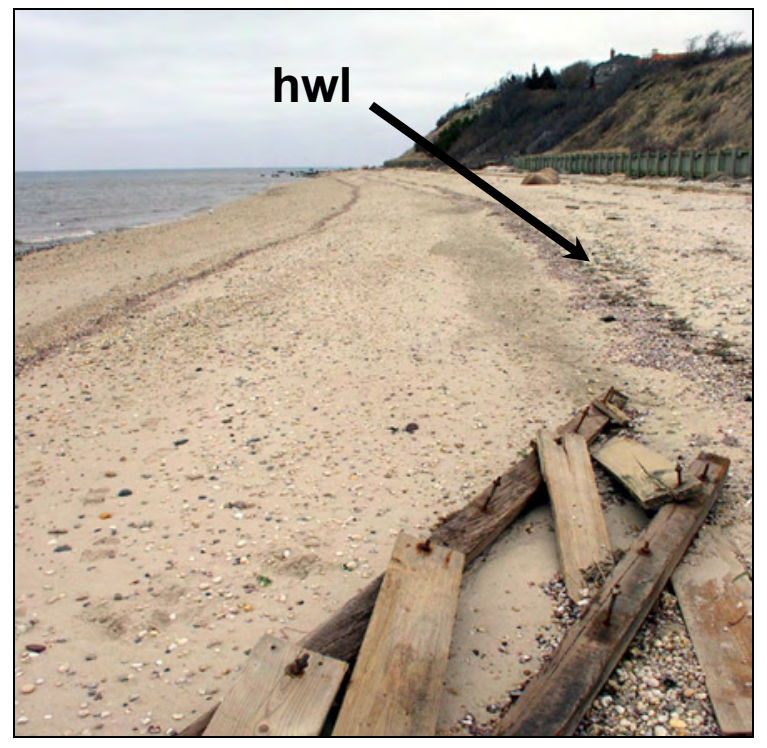

Figure 8. Example of interpreted shoreline (hwl), north shore of Long Island 


\section{Data Sources}

Shoreline data analyzed in this study originate from three sources: NOS T-sheets (topographic sheets), NOS vector shorelines, and aerial photography. Planetable mapping of the coast by the U.S. Coastal and Geodetic Survey (USC\&GS) began in the early half of the 1800 s and continued through the early 1900s. These were the first reliable surveys of shoreline position. T-sheet surveys from the first half of the $19^{\text {th }}$ century were not as rigorous as later surveys and can contain positioning errors ranging between one and tens of meters (Shalowitz 1964). Review of T-sheets produced between 1934 and 1938 by Crowell et al. (1991) found horizontal positioning errors ranging from 6 to $11.6 \mathrm{~m}(19.7$ to $38 \mathrm{ft})$. Later T-sheets were found to be more accurate, with estimated horizontal accuracies of 2.5 to $5.0 \mathrm{~m}(8.2$ to $16.4 \mathrm{ft})$ for T-sheets produced between 1844 and 1880 , and 1.5 to $4 \mathrm{~m}(5.0-13.1 \mathrm{ft})$ for sheets produced from 1880 to 1930 (Crowell et al. 1991).

The emergence of airplanes as a camera platform and aerial mosaic photography in the 1920s ushered in photogrammetric mapping. In 1927, the USC\&GS switched from planetable mapping to aerial photogrammetric shoreline mapping (Graham et al. 2003). This process reduced time in the field and allowed for the collection of data on a more frequent basis. The frequency and quality of aerial photography has increased, and most shoreline maps are now compiled using this method (Graham et al. 2003). Distortions in aerial photography due to the tilt and roll of an aircraft, and scale differences between data sources are easily corrected using modern photogrammetric techniques (Thieler and Danforth 1994).

Shoreline data sources for this study are summarized in Table 7. The majority of shorelines were obtained from OCTI and Applied Coastal and Research and Engineering, Inc. (ACREI, see Table 7 notes). Shorelines from 1838, 2001 (regional), and 2004 were digitized from digital media in the ArcMap 8.3 Geographic Information System (GIS) software package. The 1885 regional shoreline was available in digital vector format from the NOAA Shoreline Data Explorer (National Geodetic Survey 1885). NOS T-sheets from 1838 T-sheets were provided by the NOAA Coastal Services Center in raster format.

T-sheet T-55-1 was rectified with the ArcMap 8.3 software package from control points on the digital media using a secondary polynomial transformation. Map error was difficult to assess. Goodness of fit of the rectified map was evaluated against road and creek locations on a USGS digital topographic map. Overall, the fit of the digitized T-sheet matched well, giving confidence to the shoreline position data obtained. The hwl shoreline was digitized along the center of the mapped hwl, at a scale of 1:700 ft. The 2001 shoreline was digitized from digital orthophotographs retrieved from the New York GIS clearinghouse (New York State GIS Clearinghouse (NYSGIS) 2001) at a scale of 1:500 ft. Point density was varied as necessary to capture alongshore variations in shoreline position. Once the shoreline was complete, the digitized line was reviewed and individual points or sections adjusted as needed. This photoset provided a high-accuracy (National Map Accuracy Standards, see Anders and Byrnes 1991), high-resolution (0.5 ft pixel) base for the rectification of the July 2004 aerial photographs. Each image was rectified to the NYSGIS orthophotographs using a minimum of 16 control points and a second-order 
polynomial transformation. Total rms error averaged $4.5 \mathrm{~m}$ for the photograph set. The hwl was digitized at a scale of 1:700 ft.

\begin{tabular}{|c|c|c|c|}
\hline \multicolumn{4}{|c|}{$\begin{array}{l}\text { Table } 7 \\
\text { Shoreline Data Sources }\end{array}$} \\
\hline Year & Day/ Month & Data Type & Scale, ft \\
\hline $1838^{1}$ & N/A & USC\&GS T-sheet & $1: 10,000$ \\
\hline $1884 / 1885^{2}$ & $N / A$ & USC\&GS T-sheet & $1: 10,000$ \\
\hline Circa $1930^{1}$ & N/A & Aerial Photography & $1: 24,000$ \\
\hline $1955^{3}$ & 12 April & Aerial Photography & $1: 12,000$ \\
\hline $1964^{3}$ & 1 April & Aerial Photography & $1: 12,000$ \\
\hline $1965^{3}$ & 2 April & USC\&GS T-sheet & $1: 20,000$ \\
\hline $1969^{3}$ & 1 April & Aerial Photography & $1: 10,000$ \\
\hline $1976^{3}$ & 6 April & Aerial Photography & $1: 12,000$ \\
\hline $1980^{3}$ & 24 March & Aerial Photography & $1: 12,000$ \\
\hline $1993^{3}$ & 5 April & Aerial Photography & $1: 12,000$ \\
\hline $1998^{3}$ & 13 April & Aerial Photography & $1: 9,600$ \\
\hline $2001^{2}$ & 15 April & Digital Orthophotographs & $1: 400$ \\
\hline $2003^{3}$ & 16 April & Aerial Photography & $1: 700$ \\
\hline $2004^{1}$ & 15 April & Aerial Photography & 1:9600 \\
\hline \multicolumn{4}{|c|}{$\begin{array}{l}{ }^{1} \text { Digitized from media. } \\
2 \text { Local shoreline provided by OCTI \& ACREI, regional shoreline from NOAA. } \\
{ }^{3} \text { Provided by OCTI and ACREI. } \\
{ }^{4} \text { Local shoreline provided by OCTI and ACREI, regional shoreline digitized from media. }\end{array}$} \\
\hline
\end{tabular}

\section{Error Analysis}

Accuracy of shoreline positions determined from maps is limited by the original surveying standards, shrinking and stretching of the medium, projection accuracy, map scale and publication standards. Shoreline position accuracy determined from aerial photographs is dependent on location and quality of control points, aircraft tilt and pitch, altitude changes during flight, and interpretation of the shoreline feature (Anders and Byrnes 1991; Crowell et al. 1991). All aerial photographs were taken in March or April, minimizing error associated with seasonal differences in the shoreline (Douglas et al. 1998).

Comprehensive reviews of errors associated with shoreline data derived from aerial photographs and NOS T-sheets are available in the literature (Foster and Savage 1989; Anders and Byrnes 1991; Crowell et al. 1991; Thieler and Danforth 1994). These estimates, including rectification errors, were combined to give error estimates for each shoreline. Total $\mathrm{rms}$ errors associated with each shoreline in the regional and local shoreline analysis are tabulated in Tables 8 and 9 , respectively. 


\begin{tabular}{||l|l|l||}
\hline \multicolumn{3}{|l||}{$\begin{array}{l}\text { Table } 8 \\
\text { Regional Shoreline Change Error }\end{array}$} \\
\hline \hline & $\begin{array}{l}\text { rms Position Error, } \\
\mathrm{ft}\end{array}$ & $\begin{array}{l}\text { rms Error, } \\
\mathrm{ft} / \text { year }\end{array}$ \\
\hline Interval & 67.7 & 0.9 \\
\hline $1885-1965$ & 54.9 & 1.6 \\
\hline $1965-2001$ & 33.5 & 0.4 \\
\hline $1885-2001$ & \multicolumn{2}{|l||}{} \\
\hline
\end{tabular}

\begin{tabular}{||l|l|l||}
\hline $\begin{array}{l}|l| \mid \\
\text { Table 9 } \\
\text { Local Shoreline Change Error }\end{array}$ \\
\hline \hline \multicolumn{1}{|l||}{$\begin{array}{l}\text { rms Position Error, } \\
\text { Interval }\end{array}$} & $\begin{array}{l}\text { rms Error, } \\
\mathrm{ft} / \text { year }\end{array}$ \\
\hline \hline $1838-1885$ & 58.9 & 1.3 \\
\hline $1885-1930$ & 93.9 & 2.1 \\
\hline $1930-1955$ & 78.2 & 3.1 \\
\hline $1955-1964$ & 28.3 & 3.2 \\
\hline $1964-1969$ & 28.3 & 5.7 \\
\hline $1969-1976$ & 28.3 & 4.0 \\
\hline $1976-1980$ & 28.3 & 7.7 \\
\hline $1980-1993$ & 28.3 & 2.2 \\
\hline $1993-1998$ & 28.3 & 5.6 \\
\hline $1998-2001$ & 27.5 & 9.2 \\
\hline $2001-2003$ & 24.6 & 12.3 \\
\hline $2003-2004$ & 26.0 & 26.0 \\
\hline $1885-2004$ & 44.6 & 0.4 \\
\hline \hline
\end{tabular}

\section{Methods}

Shoreline change rates were calculated by both the end-point and linear regression methods. Calculation of the end-point rate is simple; the distance between two shorelines at a known point is measured, and the result is divided by the time interval to give the change rate. The end-point rate is easily applied to data series and commonly used; however, there are some disadvantages. Results are controlled by the accuracy of individual shorelines, and the rate does not represent processes occurring between the two data points (Dolan et al. 1991). The method of linear regression is an accepted alternative to the end-point method (Foster and Savage 1989; Dolan et al. 1991). This method incorporates a least-squares solution to determine a change rate from a series of shoreline positions, with no weight given to time intervals. The resulting rate represents intermediate shorelines, but is sensitive to the temporal spacing of the data. 
The purpose of this study is to determine the long-term response of the adjacent beaches to the Federal navigation project at Mattituck Inlet. For this reason, the end-point rate was selected as the primary method of determining shoreline change rates. Although intermediate shoreline movements are of value for understanding processes at the site, net changes are best represented by the end-point method. The linear regression method was applied in conjunction with the end-point method to provide insight into intermediate processes in longterm intervals and to verify change determined from end-point analysis.

Shoreline positions were measured within BeachTools, an ArcView 3.2 extension (Hoeke et al. 2001), from a baseline established parallel to the local shoreline orientation at an interval of $15 \mathrm{~m}(49.2 \mathrm{ft})$. BeachTools measures shoreline distance by generating transects perpendicular to a baseline at a user-specified interval. Shoreline change transects were evaluated for overlap after initial generation. If overlap occurred, transects having the best fit to the local shoreline orientation were retained. Shoreline distances, relative to the baseline, were exported, and change rates were calculated in Matlab ${ }^{\circledR}$. A lowpass filter was applied to the change rates to remove high-frequency noise associated with the dense spatial sampling of the shorelines.

\section{Relative Sea-Level Rise}

Shoreline evolution is influenced by sediment transport processes, and, if applicable, the long-term trend in relative sea-level rise. This study concerns time scales of coastal change over which sea-level rise is relevant. Therefore, shoreline regression attributed to sea-level rise was determined and reported for shoreline and volumetric change estimates. The mean sea-level trend between 1957 and 1992, as documented by the NOS at Port Jefferson, NY, approximately 28 miles from Mattituck Inlet, is $0.8 \mathrm{ft} /$ century $(2.44 \mathrm{~mm} /$ year $)$. Shoreline regression resulting from sea-level rise was estimated by dividing rate of sealevel rise over the period of interest and by the average foreshore slope (0.08) determined from available beach profile survey data. Table 10 lists land losses attributed to relative sea-level rise for time scales represented in this study, as determined from average beach slope in the vicinity of Mattituck Inlet.

\begin{tabular}{|c|c|}
\hline \multicolumn{2}{|c|}{$\begin{array}{l}\text { Table } 10 \\
\text { Shoreline Recession Due to Sea-Level Rise }\end{array}$} \\
\hline Period, year & Recession, ft \\
\hline 1 & 0.1 \\
\hline 10 & 1.0 \\
\hline 25 & 2.5 \\
\hline 50 & 5.0 \\
\hline 75 & 7.5 \\
\hline 100 & 10.0 \\
\hline
\end{tabular}




\section{Regional Shoreline Change}

The regional study area was defined according to the geomorphology of the coast. The north shore of Long Island can be divided into two reaches based on shoreline trends and topography (Davies et al. 1973). The western reach, from Willets Point to Port Jefferson (149 miles), is highly irregular, composed of prominent headland points separating deep bays and harbors. The eastern reach extends from Port Jefferson to Orient Point (68 miles) with eroded headlands separating gentle embayments. Bluffs are mostly continuous within this reach. Bluff heights between Port Jefferson and Herod Point range from 100 to $140 \mathrm{ft}$, then decrease from Herod Point toward Orient Point to about $33 \mathrm{ft}$ (Davies et al. 1973). East of Port Jefferson, the shoreline is interrupted by Mt. Sinai Harbor, Wading River Inlet, a small inlet at Fresh Pond, and Mattituck and Goldsmith Inlets (Figure 9). The regional study area will encompass this eastern reach of the north shore of Long Island.

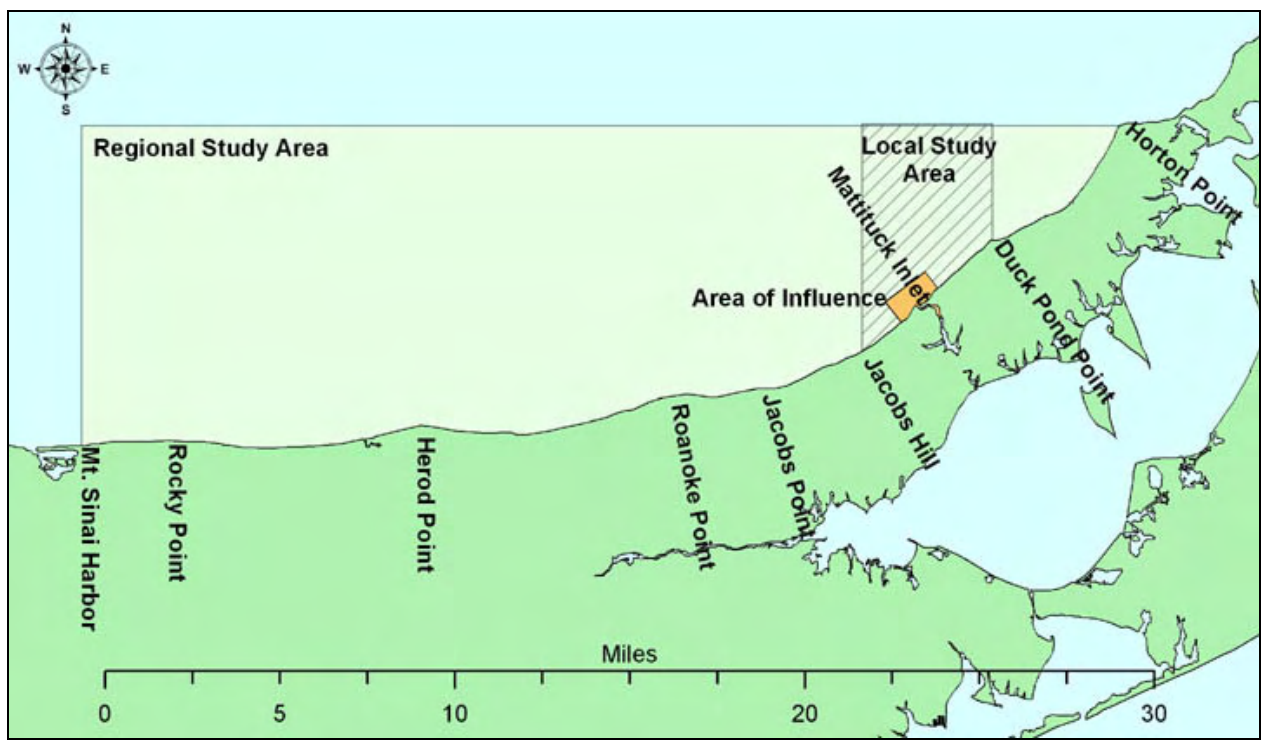

Figure 9. Regional and local study areas for shoreline change rates

Shoreline data were available within this region for 1885 and 1965 (USC\&GS), and regional orthophotographs were available for 2001. These sources allowed for calculation of shoreline change rates by the end-point method for the 1885 to 1965,1965 to 2001 , and 1885 to 2001 intervals. The orientation of the shoreline between Port Jefferson and Mt. Sinai Harbor is not representative of the remainder of the study area; therefore, the western boundary was set east of Mt. Sinai Harbor (Cedar Beach). The eastern boundary was determined by the extent of the 1965 shoreline, which was limited to Horton Point (Figure 9). Shoreline change was calculated for each interval via the endpoint method and for duration of the study by both the end-point and linear regression methods. Because of the orientation of the shoreline to the baseline, Roanoke and Jacobs Points are not properly represented in Figures 10 through 12. 
Shoreline recession was the dominant trend for the region between 1885 and 2001, though rates were higher during the 1885 to 1965 interval. The period from 1885-1965 exhibited recession of the entire regional coast. Vertical lines in Figures 10, 11, and 12 represent the position of Mattituck Inlet and denote headland points in the region. Analysis results showed that locations exhibiting accretion were typically related to shore protection structures. In Figure 10, shoreline advance peaks at 7, 8, 15,22, 24, and 28 miles correspond to groins at the Long Island Lighting Company (LILCO) nuclear plant in Wading River, Wading River Beach, Friars Head, and Northville, and jetties at Mattituck and Goldsmith Inlets, respectively. No structure is present at the first peak (about 1 mile). The average rate of shoreline recession between 1885 and 1965 for the region was $1.2 \mathrm{ft} /$ year.

The region was more stable through the 1965 to 2001 interval (Figure 11), with a recession rate of $0.5 \mathrm{ft} /$ year. Overall, the shoreline change rate oscillates around 0, with a large area of recession between Mt. Sinai and Wading River. Strong shoreline advance signals are apparent at the LILCO groins (8 miles), the Northville groins (22 miles), Mattituck Inlet (24 miles), and Goldsmith Inlet (29 miles), shown in Figure 11.

Shoreline change rates determined from 1885 to 2001 show the influence of the early half of the $20^{\text {th }}$ century on long-term shoreline recession rates. Analysis of the regional shoreline from Mt. Sinai Harbor to Horton Point demonstrated that the eastern north shore of Long Island has a long-term trend of shoreline recession at a rate of approximately $1 \mathrm{ft} /$ year in the last 116 years. Shoreline advance was limited to areas updrift of shore protection structures. Seven areas of shoreline advance are present, with six corresponding to shoreline protection structures at Wading River (LILCO and Town Beach), Friars Head, Northville, Mattituck Inlet, and Goldsmith Inlet (Figure 12). The shoreline change adjacent to Mattituck Inlet was the dominant signal in the region. The highest rate of shoreline advance observed was located directly updrift of Mattituck Inlet between 1885 and 2001. The shoreline directly downdrift of the inlet had the highest value of shoreline recession for the 1885 to 1965 interval. This recession area downdrift of the inlet is also apparent between 1965 and 2001, though at a lower rate compared to the previous interval. The magnitude and extent of shoreline change rates directly updrift and downdrift of the inlet are investigated in the following section. 

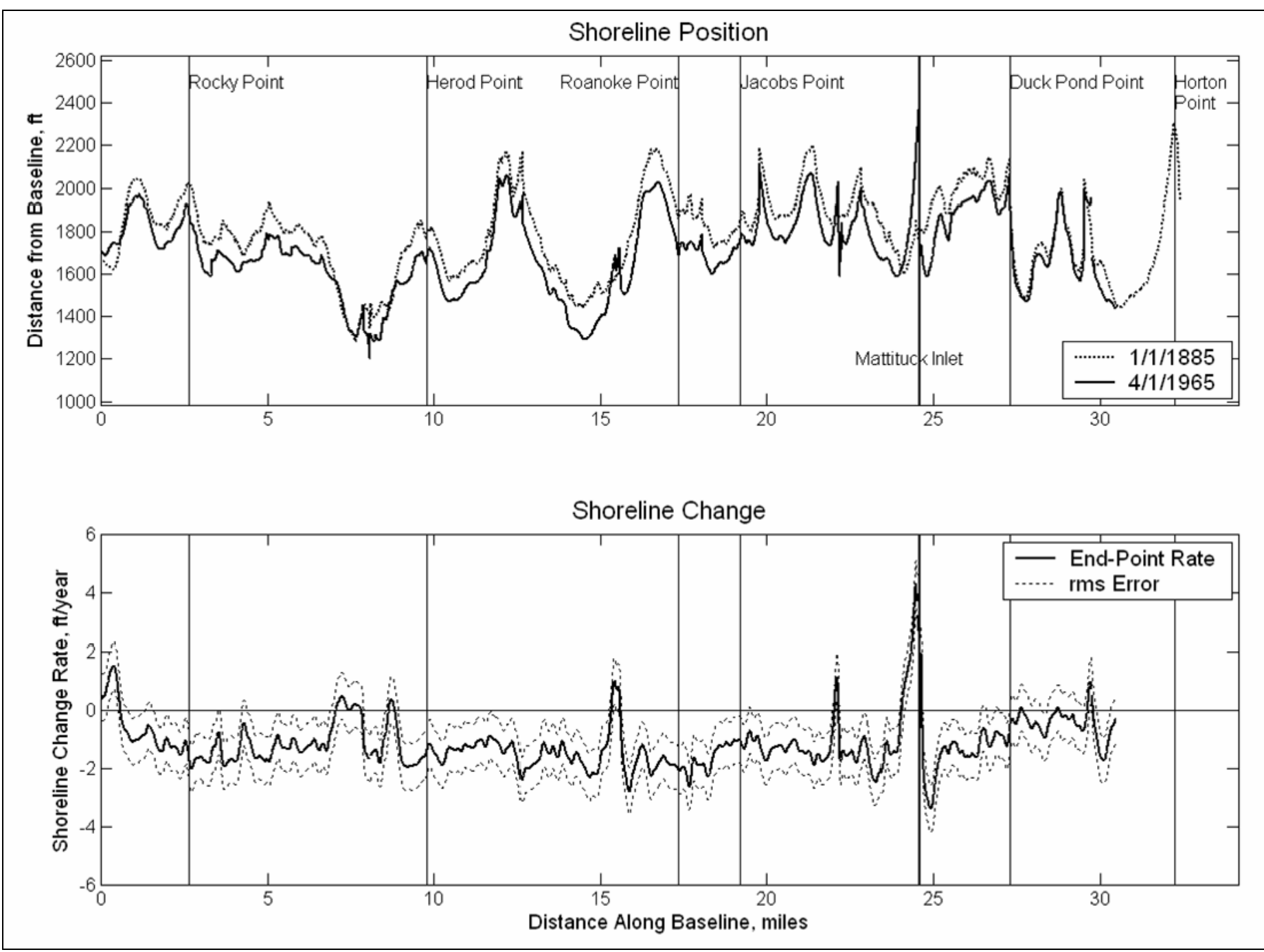

Figure 10. Regional shoreline changes between 1885 and 1965 


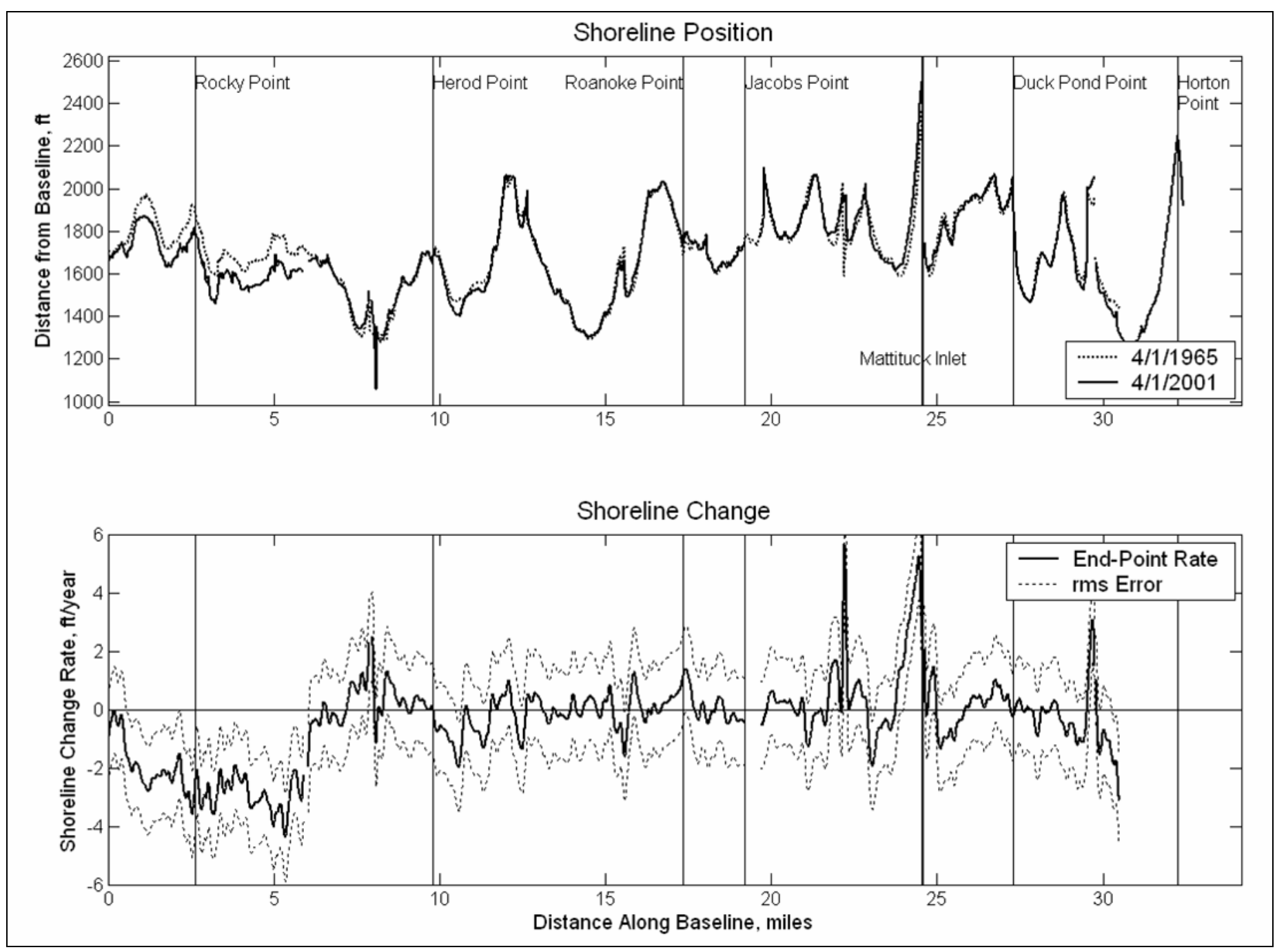

Figure 11. Regional shoreline changes between 1965 and 2001 

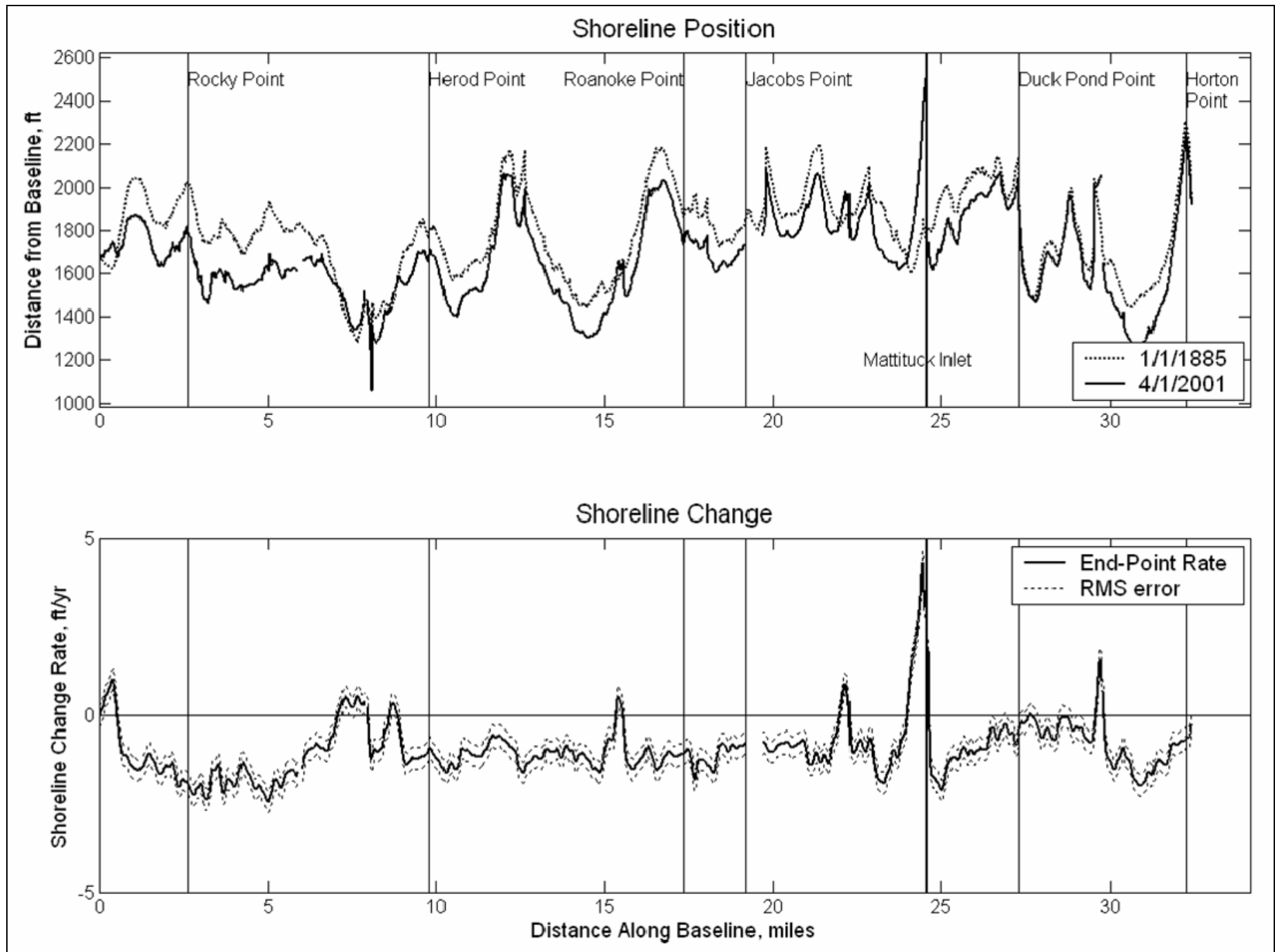

Figure 12. Regional shoreline change between 1885 and 2001 


\section{Local Shoreline Change}

On the local project scale, shoreline position data were available in higher temporal resolution than for the region. Thirteen shoreline surveys were available for the vicinity of Mattituck Inlet between 1838 and 2004. These data were analyzed to determine both the magnitude and extent of shoreline change induced by the construction of the Mattituck Inlet jetties and navigation channel. Federal responsibility for beach erosion downdrift was evaluated from these results.

\section{Preexisting condition}

Two shoreline data sets are available prior to the stabilization of Mattituck Inlet in 1906. Shoreline position derived from the $1838 \mathrm{~T}$-sheet is considered qualitative, because it was difficult to assess the error of position data derived from the original T-sheet. The $1838 \mathrm{~T}$-sheet (Figure 13) shows the natural configuration of Mattituck Inlet. At the time of survey, the inlet was located approximately $600 \mathrm{ft}$ to the east of the position recorded in 1885 .

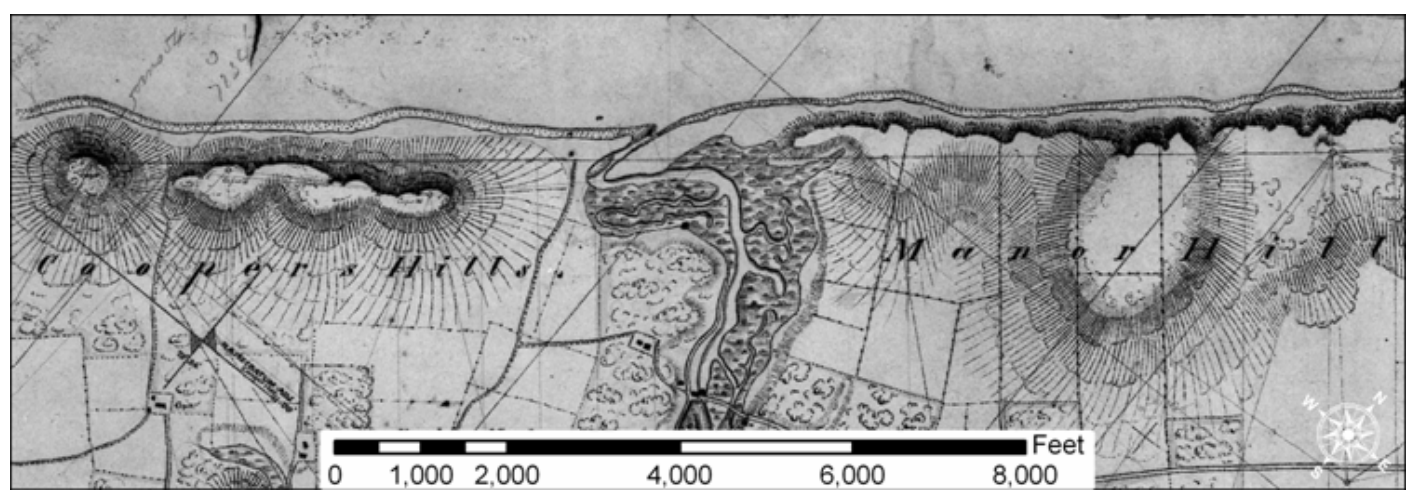

Figure 13. Mattituck Inlet and vicinity, 1838, NOS T-sheet T-55-1

Shoreline position and shoreline change rates from 1838 to 1885 are shown in Figure 14. Because of large positioning errors associated with early USC\&GS T-sheets, shoreline change and change rates calculated for this interval should be considered descriptive. Shoreline change alternated between recession and advance within the study area. Recession of the shoreline is observed in the vicinity of Mattituck Hills and Duck Pond Point. Shoreline advance is observed in the direct vicinity of the inlet, most likely a result of deposition of material released by shoreline and bluff recession in the Mattituck Hills area. Moving away from the inlet to the east (downdrift), low rates of shoreline recession are observed for $1 / 2$ mile, switching to shoreline advance at $3 / 4$ mile from the inlet.

Shoreline advance persists for slightly over 1 mile west of Duck Pond Point, where recession rates begin and increase to the east. Shoreline recession within this time interval appears to be concentrated at headland points, followed by redistribution of material downdrift. 


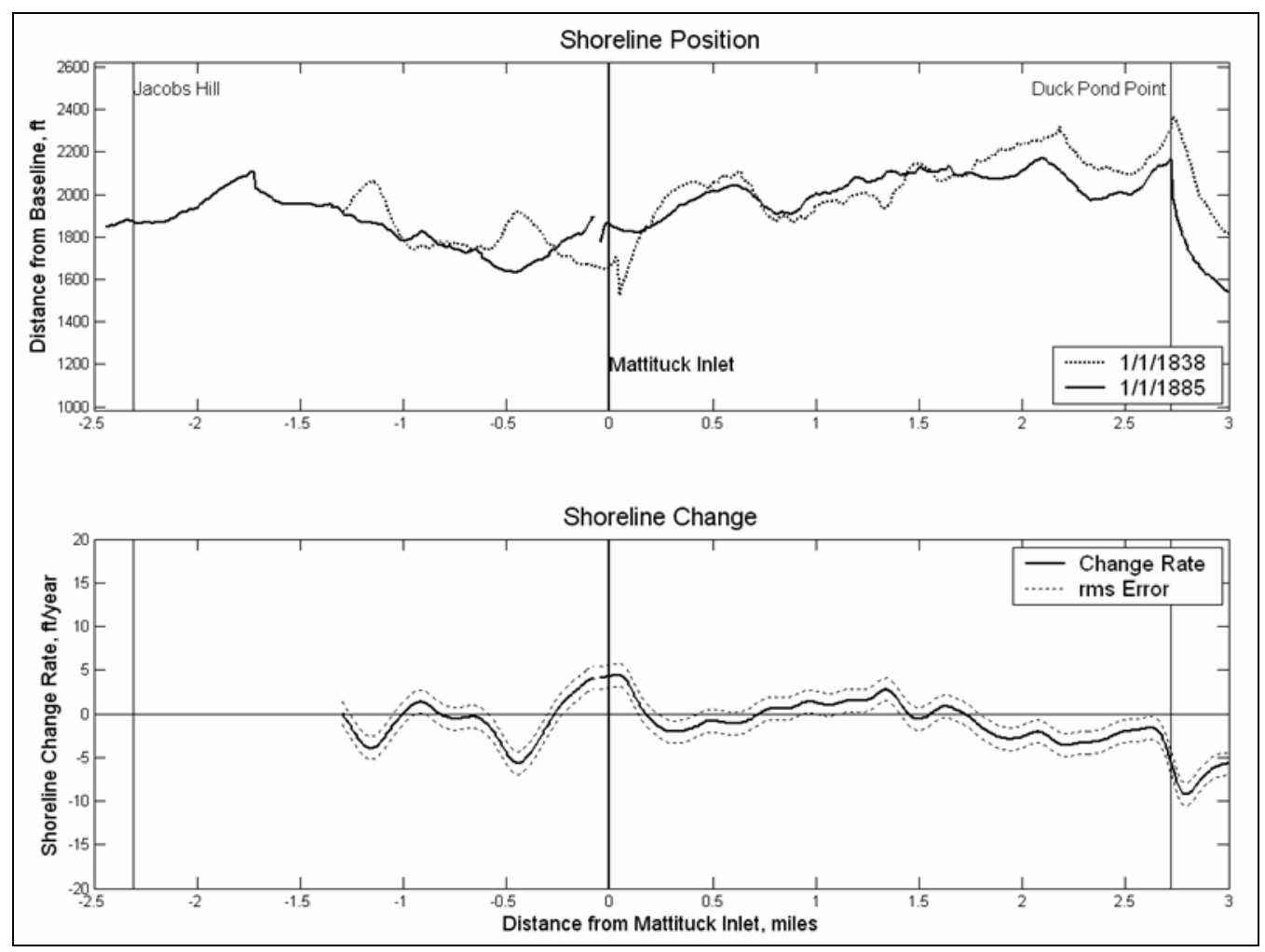

Figure 14. Shoreline position and change rate between 1838 and 1885

\section{Successive intervals}

Although long-term shoreline change rates contain less error and are considered most appropriate for evaluating net change, knowledge can be gained by examining shoreline change in the short term. Shoreline change and change rates were calculated between each successive interval to investigate recession and advance through time. Impoundment of material updrift of the inlet occurred rapidly. Records indicate that sediment began bypassing the updrift jetty and shoaling the channel in the early to mid 1920s (Ralston 1929). Shoreline change between 1885 and 1930 reflects this buildup of sediment updrift, with shoreline advance rates approaching $10 \mathrm{ft} /$ year just west of the inlet (Figure 15). Approaching the inlet from the west, the trend rapidly changes from erosion to accretion approximately one-half mile updrift of the inlet, and increases as it nears the structure. Downdrift of the inlet, shoreline recession rates are greater than the local trend for approximately 0.6 miles.

The downdrift shoreline to Duck Point was stable between 1930 and 1955. However, the jetty shadow is an apparent departure from this trend (Figure 16). The spatial extent of the recession area increased to almost 1 mile downdrift of the inlet from the previous interval. Aerial photographs from this time period show considerable recession of the downdrift beach, with the shoreline eventually receding landward of the entire east jetty circa 1935 (Morgan et al. 2005). This condition apparently persisted until 1946, when material dredged from the inlet entrance 


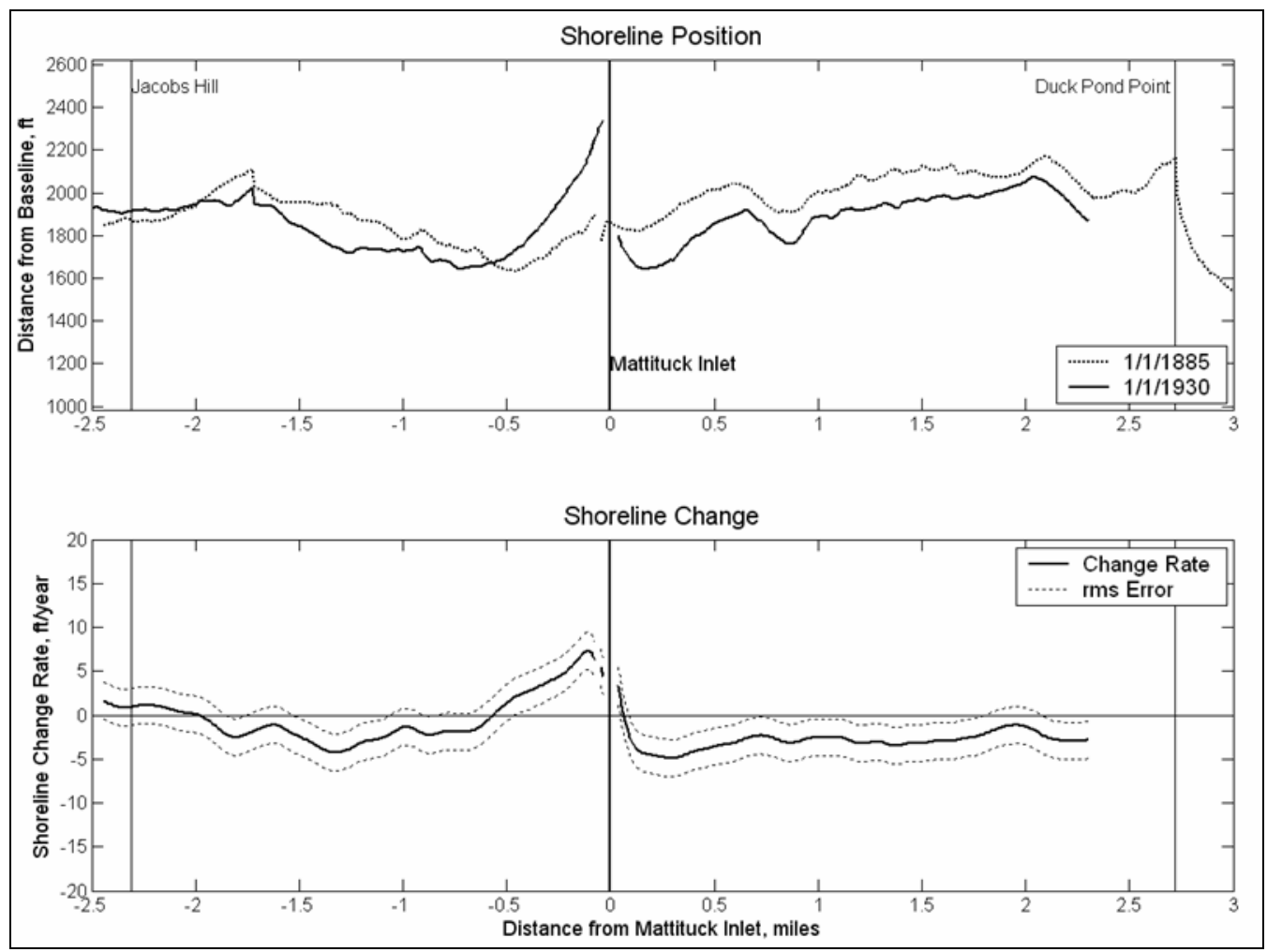

Figure 15. Shoreline change between 1885 and 1930

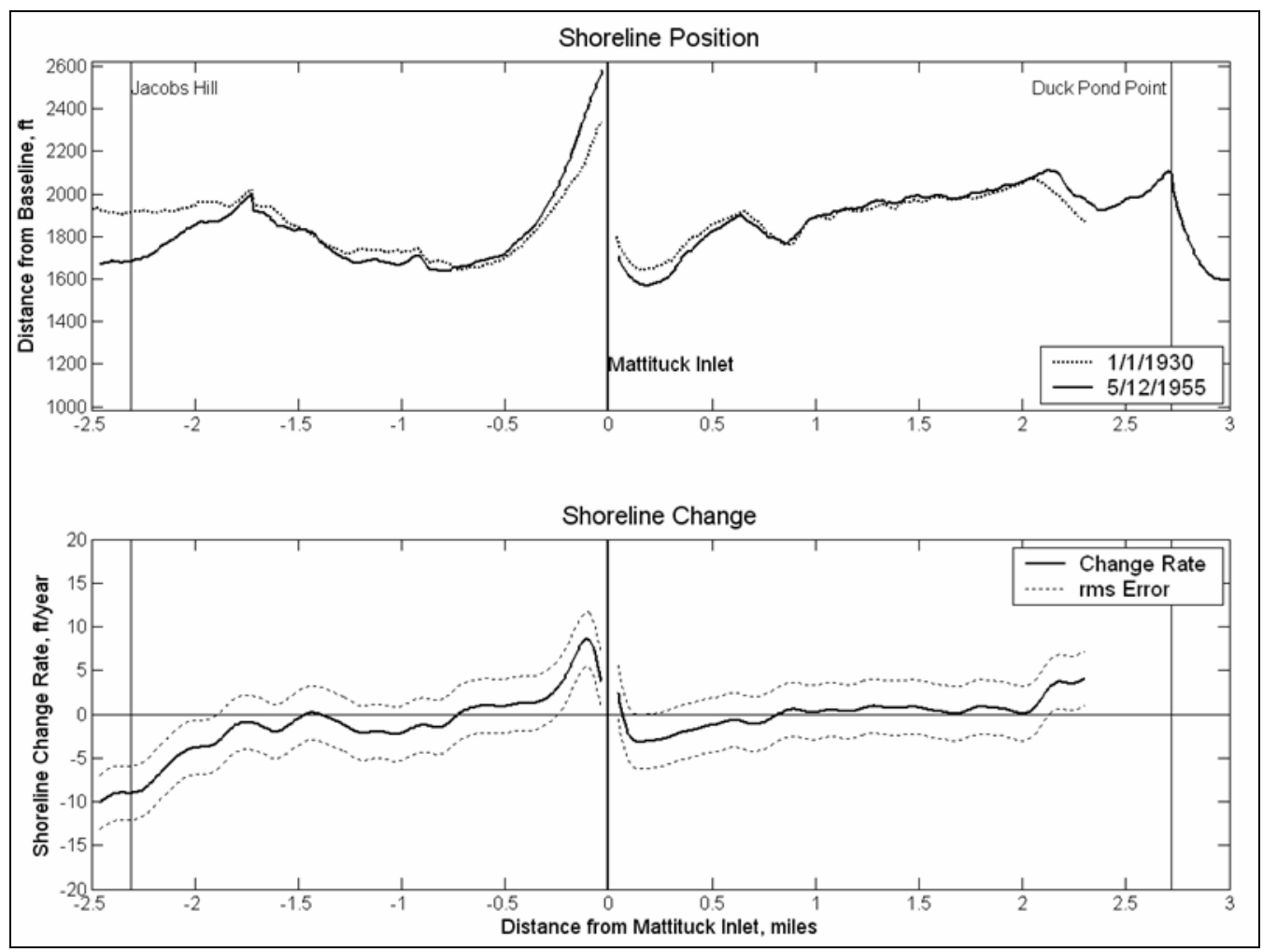

Figure 16. Local shoreline change from 1930 to 1955 
channel was placed on the downdrift beach. The aerial photographs shown in Figure 17(a) document the severely receded shoreline in 1938 and (b) the improved post-dredged material placement condition in 1947.

The inlet channel was dredged five times from 1930 to 1955 (1936, 1938, 1946, 1950, 1955; Table 4). Condition surveys indicate that dredged material was placed directly on the downdrift beach during 1946 and 1950 (New York District channel condition reports). Placement of this material restored the downdrift beach, skewing recession rates for this interval. Updrift of the inlet, the rate of shoreline advance decreased to $1-2 \mathrm{ft} /$ year in about half the distance (1/4 mile) as compared to the previous interval (1885-1930).

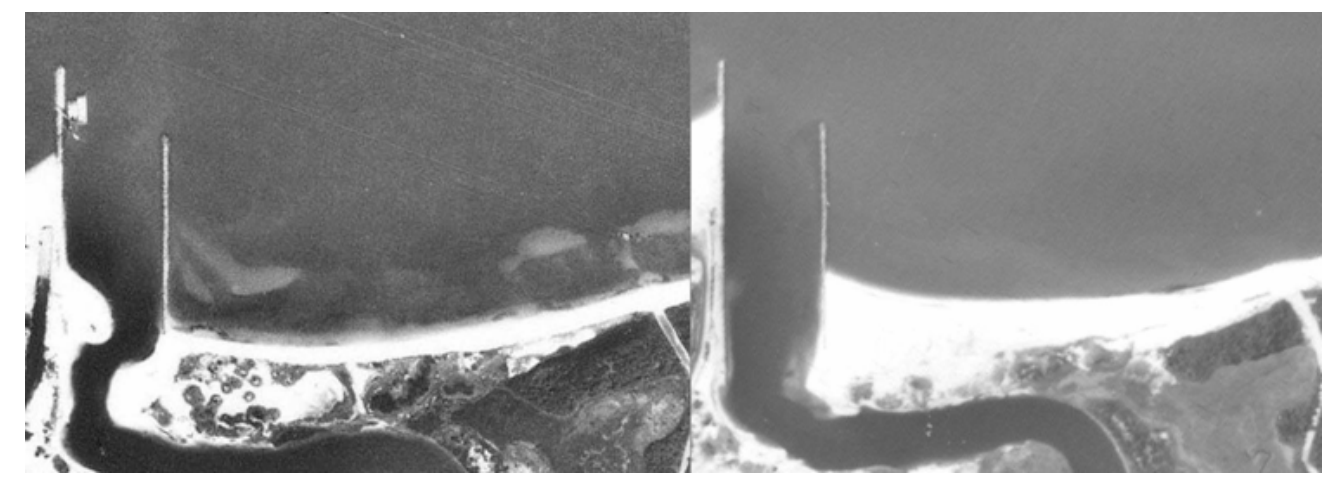

(a) 1938 receded shoreline

(b) 1947 post-dredged material placement

Figure 17. Photographs of Mattituck Inlet

From 1961 to 1975 , material was mined from the impoundment fillet west of the inlet, removing an estimated 243,000 cu yd from the site (Schubel 1976; Table 6). This removal of material is indicated by a reversal of the shoreline change trend updrift of the inlet during both the 1955 to 1964 and 1964 to 1969 intervals. Shoreline recession rates within the impoundment compartment rates range from 5 to $15 \mathrm{ft} /$ year (Figure 18) between 1955 and 1964. In contrast to prior trends, shoreline advance is observed directly downdrift of the inlet during this interval. Dredging of the inlet channel occurred during 1955 and 1961; however, disposal of this material was not documented. It is likely that material was placed on the downdrift beach, as it was during dredging operations in 1946 and 1950.

The shoreline change trend for the downdrift beach returned to recession during the 1964 to 1969 interval, but was limited to a smaller spatial extent than in previous intervals (about 0.3 mile). Dredging was undertaken again in 1965. Shoreline recession rates during this short interval were not in accord with indicated local placement of the material (approximately 47,000 cu yd) on the downdrift beach. Shoreline change trends were similar between 1969 and 1976. During this time, recession in the jetty shadow was limited spatially, and rates were not higher than those observed elsewhere in the local area. 


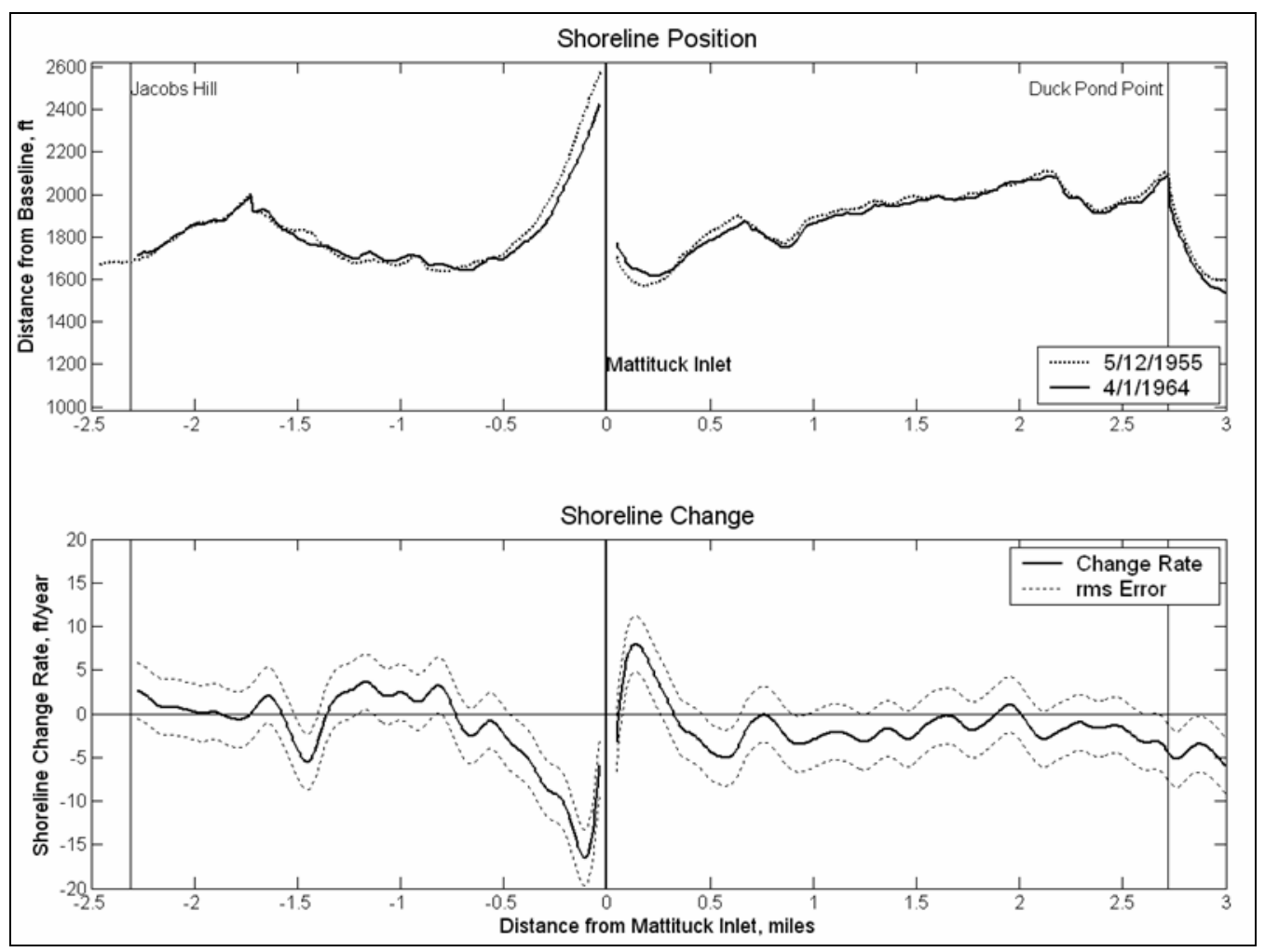

Figure 18. Shoreline change from 1955 to 1964

Mining of the impoundment fillet declined between 1969 and 1976, likely due to reduced longshore transport of material to the site. This reduction may be attributed to construction of jetties at Jacobs Hill, near the town of Northville, about 2.5 miles updrift of Mattituck Inlet (Schubel 1976). Records indicate that these structures were built by Curtiss, Wright, and Levon Industries for sand mining and possible harbor development. Installation of these jetties began in 1967 and was complete by 1969 . The east jetty was constructed out of sunken barges, railroad cars, and a steel coal float, whereas the west jetty was constructed of rock. Despite differences in construction, both jetties had the same length, extending about $500 \mathrm{ft}$ into Long Island Sound, with a gap of $500 \mathrm{ft}$ (Schubel 1976). Although construction of the jetties deprived downdrift beaches of material, aerial photographs show that mining operations also released sediment (probably finer material) into the littoral system (Figure 19). While this mining occurred, shoreline change trends along the shoreline updrift of Mattituck Inlet alternated between recession and advance. From 1964 to 1969, the updrift shoreline receded, advanced between 1969 and 1976, and then receded again from 1976 to 1980. Although the shoreline data did not extend to Jacobs Hill, it is likely that these trend reversals were caused by sand trapping updrift of the Northville jetties, combined with intermittent releases of sediment during sand mining operations.

Mining operations at Northville were abandoned in the early 1970s, and the jetties were partially dismantled by 1972 (Schubel 1976). Comparison of aerial photographs from 1969 and 1994 show the lengths of the Northville jetties were approximately reduced by half. In the 1994 aerial photograph, the compartments updrift of and between the jetties appear fully impounded. The shoreline 
between Mattituck Inlet and the Northville groins was stable from 1980 to 1993, and the trend of shoreline advance (approximately $5 \mathrm{ft} /$ year) reappeared in the impoundment area updrift of Mattituck Inlet (Figure 20). Downdrift, shoreline recession was apparent, and over a longer stretch of coast than previous intervals (2-1/8 miles), with rates approaching $4.5 \mathrm{ft} /$ year. Shoreline change rates directly downdrift of the inlet suggested fill placement.

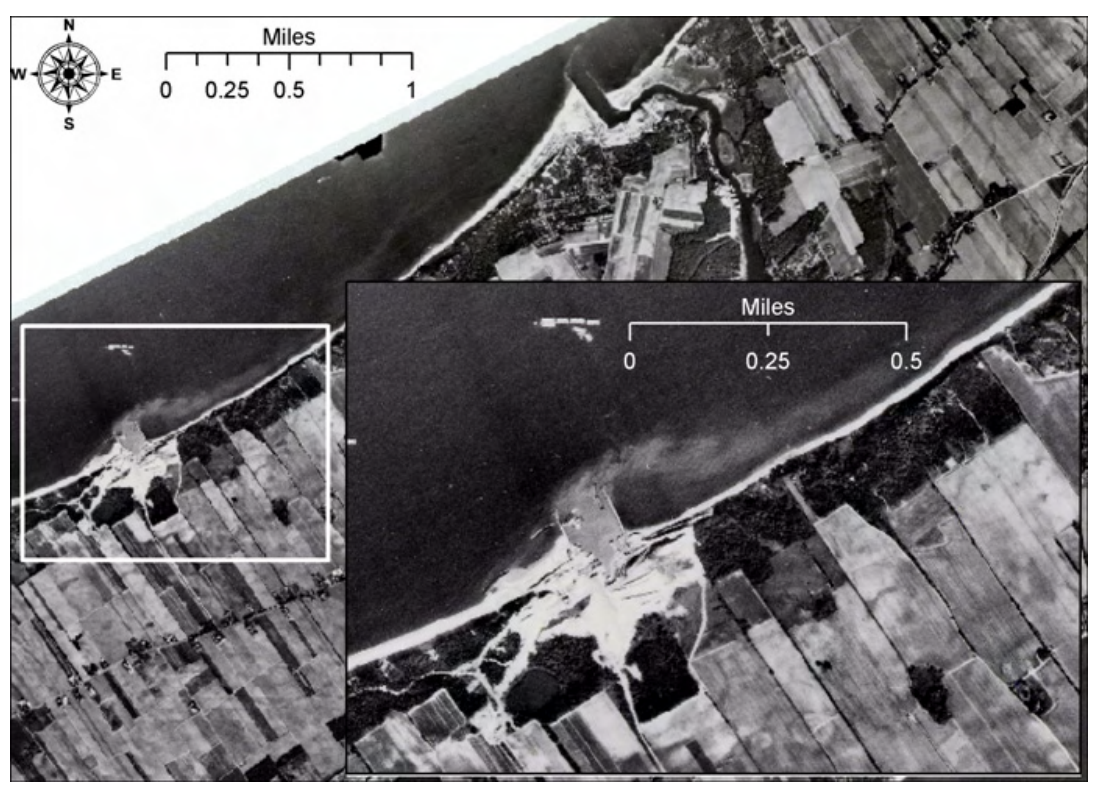

Figure 19. Material entering the littoral system at Northville as a result of sand mining, October 1969 


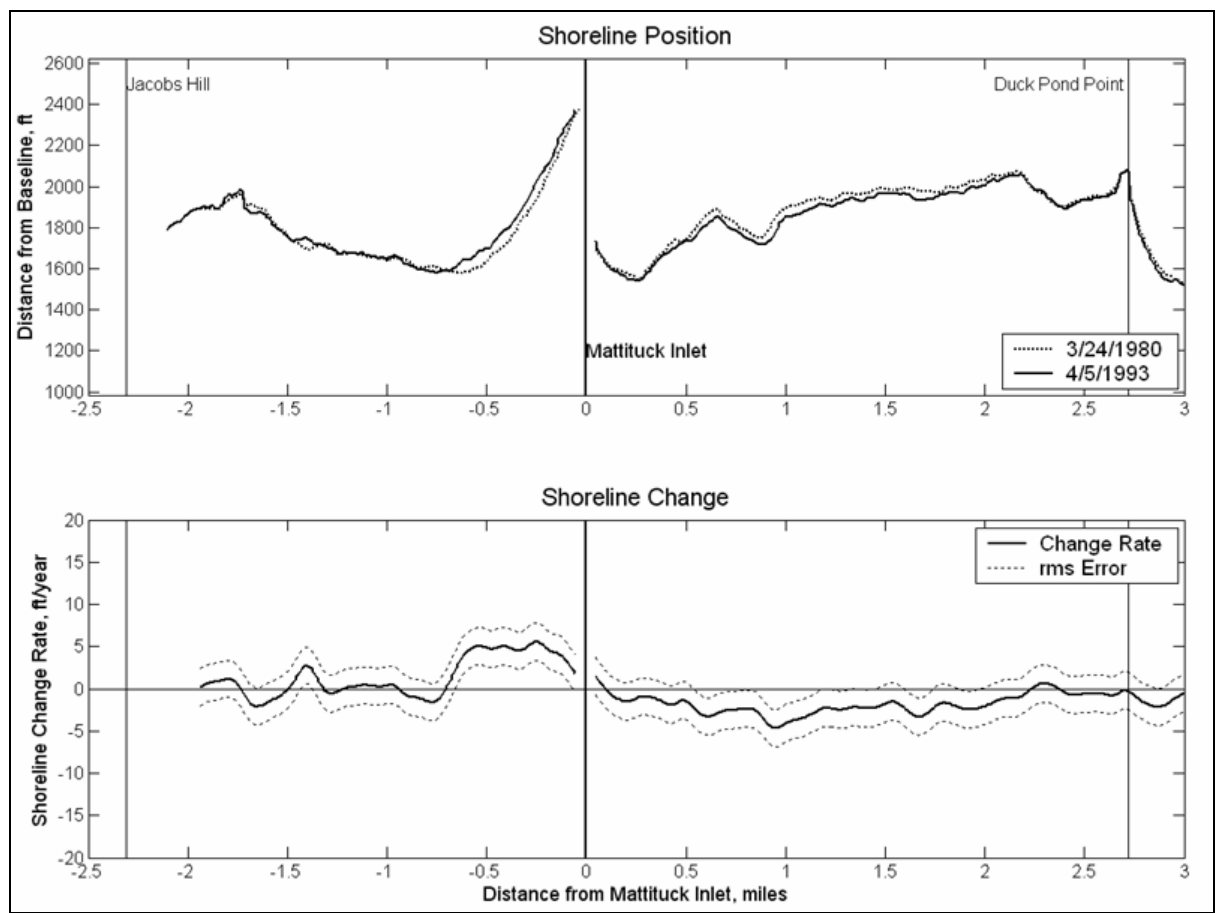

Figure 20. Shoreline change from 1980 to 1993

Shoreline change intervals between 1993 and 2004 are shorter (1- to 5-year length) and thus prone to larger amounts of error because of naturally occurring fluctuations. These intervals were combined into one longer time period (1993 to 2004) (Figure 21). Overall, shoreline position was stable, and shoreline advances occurred on both the east and west sides of the inlet. Shoreline advances downdrift are partially attributable to placement of dredged material during this interval. The Mattituck Inlet entrance was dredged in March 2004, and approximately $13,000 \mathrm{cu}$ yd of material removed from the inlet channel was placed on the beach directly downdrift (Figure 22). The July 2004 aerial photographs show that shoreline position was advanced $100 \mathrm{ft}$ directly downdrift of the inlet (compared to April 2003 photographs), tapering to $15 \mathrm{ft}$ within 1/4 mile, and to zero gain at $1 / 2$ mile from the inlet. Decreased recession rates and stability during this interval may also be attributed to long-term adjustment and maturation of the downdrift shoreline towards an equilibrium crenulate bay planform (Krumbein 1944; Yasso 1965; Silvester 1970; Hsu and Evans 1989).

Overall, the shoreline change data indicate that stabilization of Mattituck Inlet has modified the evolution of the adjacent shorelines, resulting in shoreline advance updrift of the inlet and shoreline recession downdrift of the inlet (Figure 23). The inlet imposed the strongest signal between 1885 and 1955 as the shoreline planform adjusted to the installation of the jetties. Overall, the recession rate downdrift of the inlet decreased. After 1955, the signal both downdrift and updrift becomes mixed. This mixed signal is a product of several factors, including reduction of longshore transport into the Mattituck littoral cell in response to construction of jetties at Northville (1964-1980), placement of material dredged from the inlet channel entrance on the downdrift beach 
(1946-2004), and evolution of Mattituck Inlet into a mature inlet system (1993-2004).

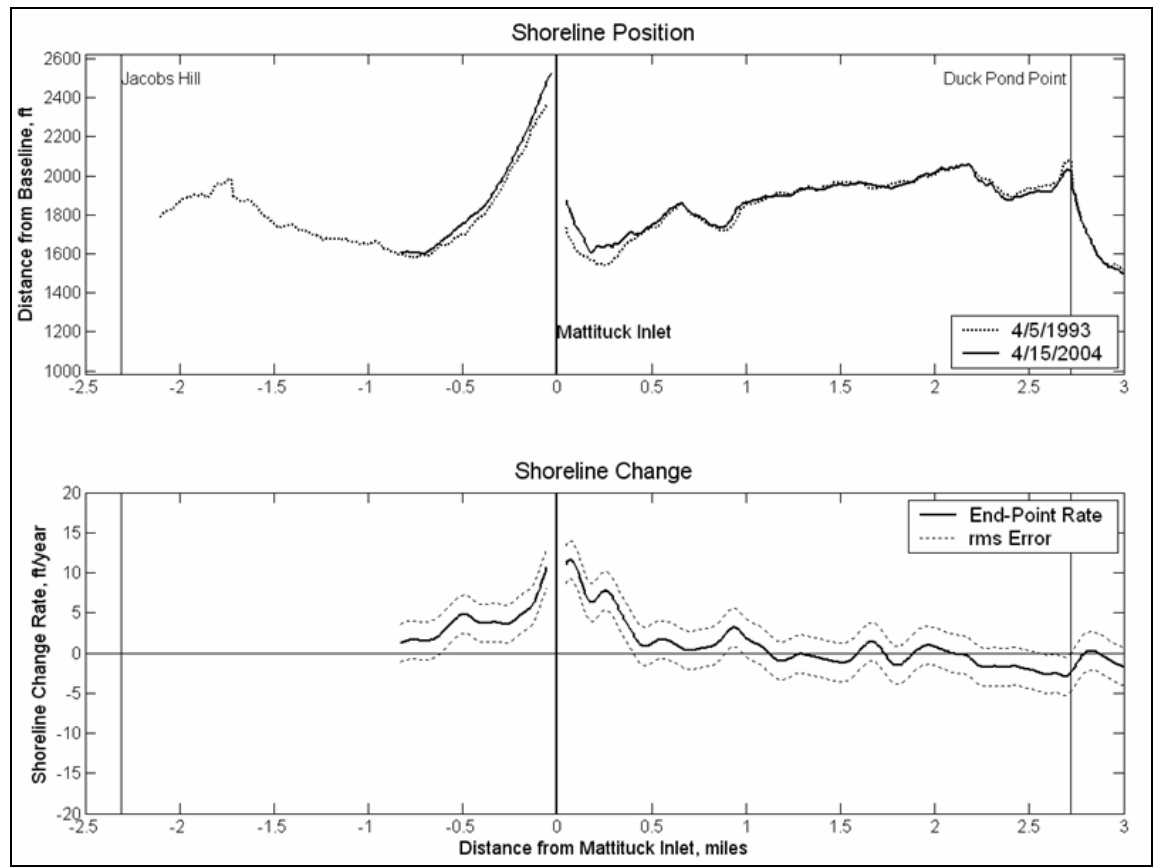

Figure 21. Shoreline change between 1993 and 2004

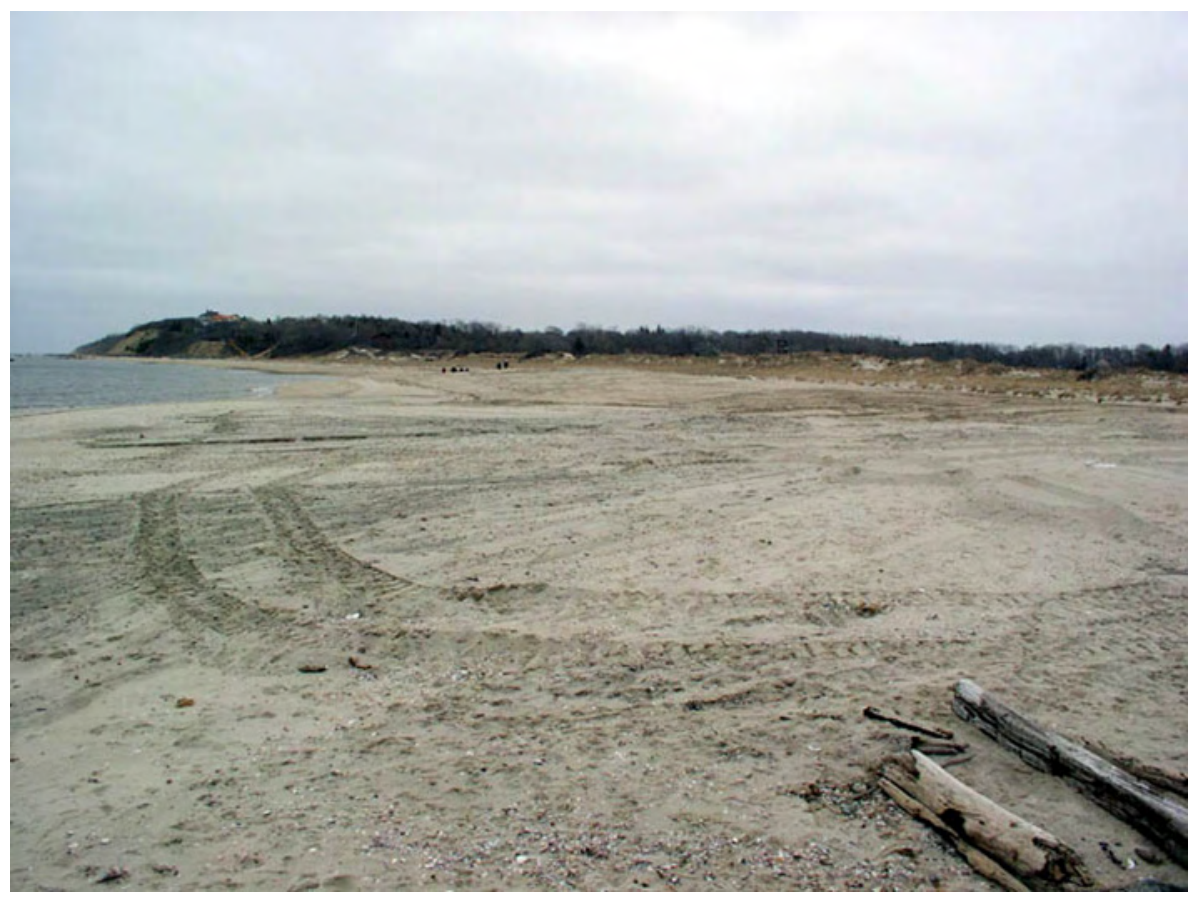

Figure 22. Dredged material placement directly downdrift of Mattituck Inlet, March 2004 


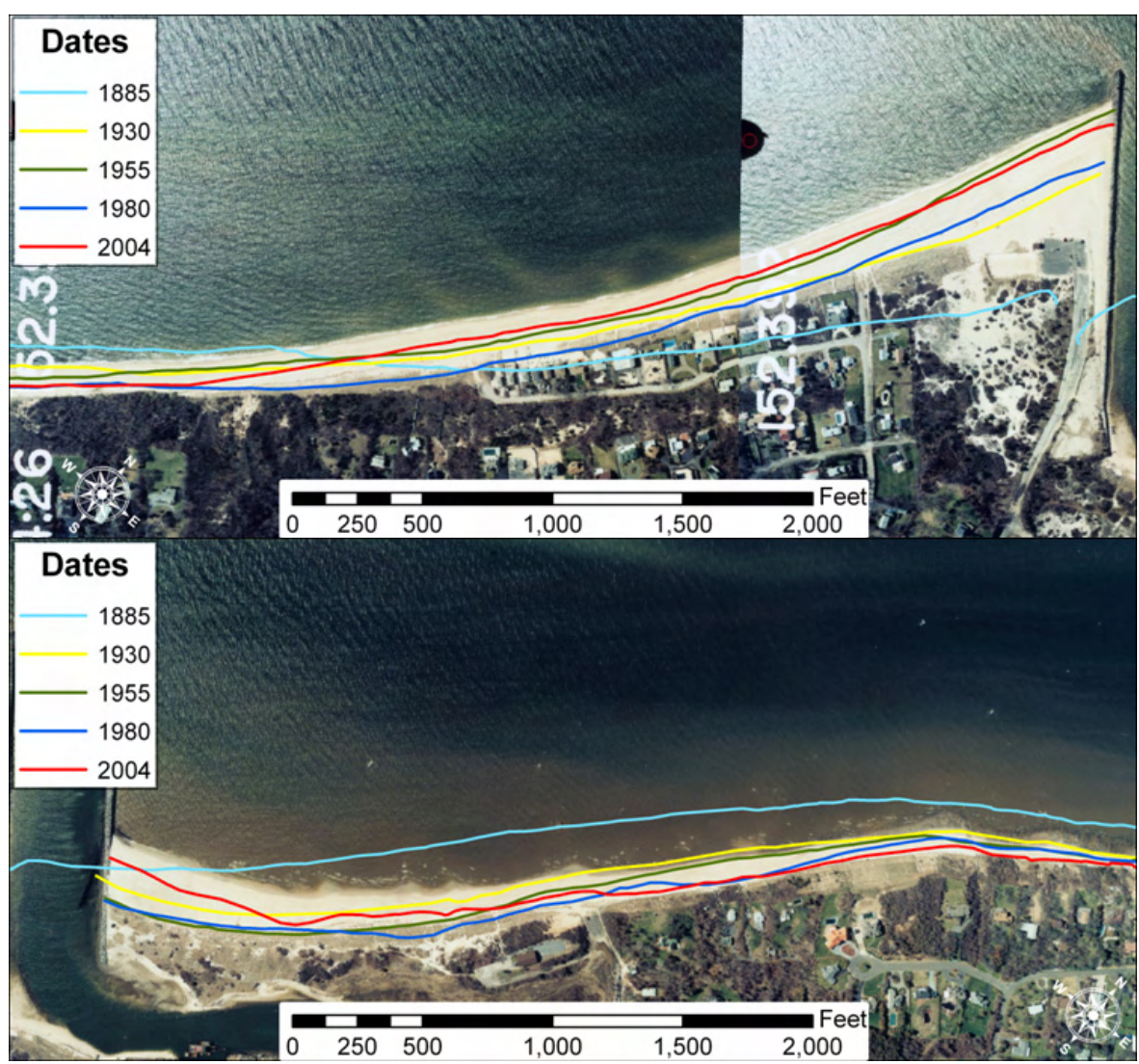

Figure 23. Selected interpreted hwl shorelines east and west of Mattituck Inlet

\section{Delineation of impoundment and erosion areas}

To evaluate shoreline change, in particular, recession attributable to the Federal navigation project at Mattituck Inlet, it was first necessary to delineate the spatial extent of shoreline advance and recession. This assessment was accomplished by calculating long-term shoreline change rates between 1885 and 2003, and then removing the regional background recession rate from the shoreline change signal. This approach produced a residual shoreline change rate assumed to be associated with the Federal navigation project and commercial mining. Shoreline change rates above and below the residual rate are considered to represent the influence of the inlet on the adjacent shorelines. Residual rates so determined are shown in Figure 24.

Shoreline advance occurred for approximately $3,500 \mathrm{ft}$ to the west (updrift) of the inlet. This reach of shoreline defines the extent of shoreline advance, or the impoundment area. Downdrift of the inlet, two zones of shoreline recession were apparent, extending for a total distance of approximately $9,600 \mathrm{ft}$ east (Figure 24). These zones of sediment accretion and erosion were defined by the magnitude of the residual rate. The first zone, or primary recession area, consists of the $4,000 \mathrm{ft}$ of shoreline directly to the east of the inlet. Along the next $5,600 \mathrm{ft}$, the east shoreline recession rates decrease; this area is defined as the secondary recession area. Figure 25 provides an overlay of the shoreline advance area and the primary and secondary erosion areas on aerial photography. 


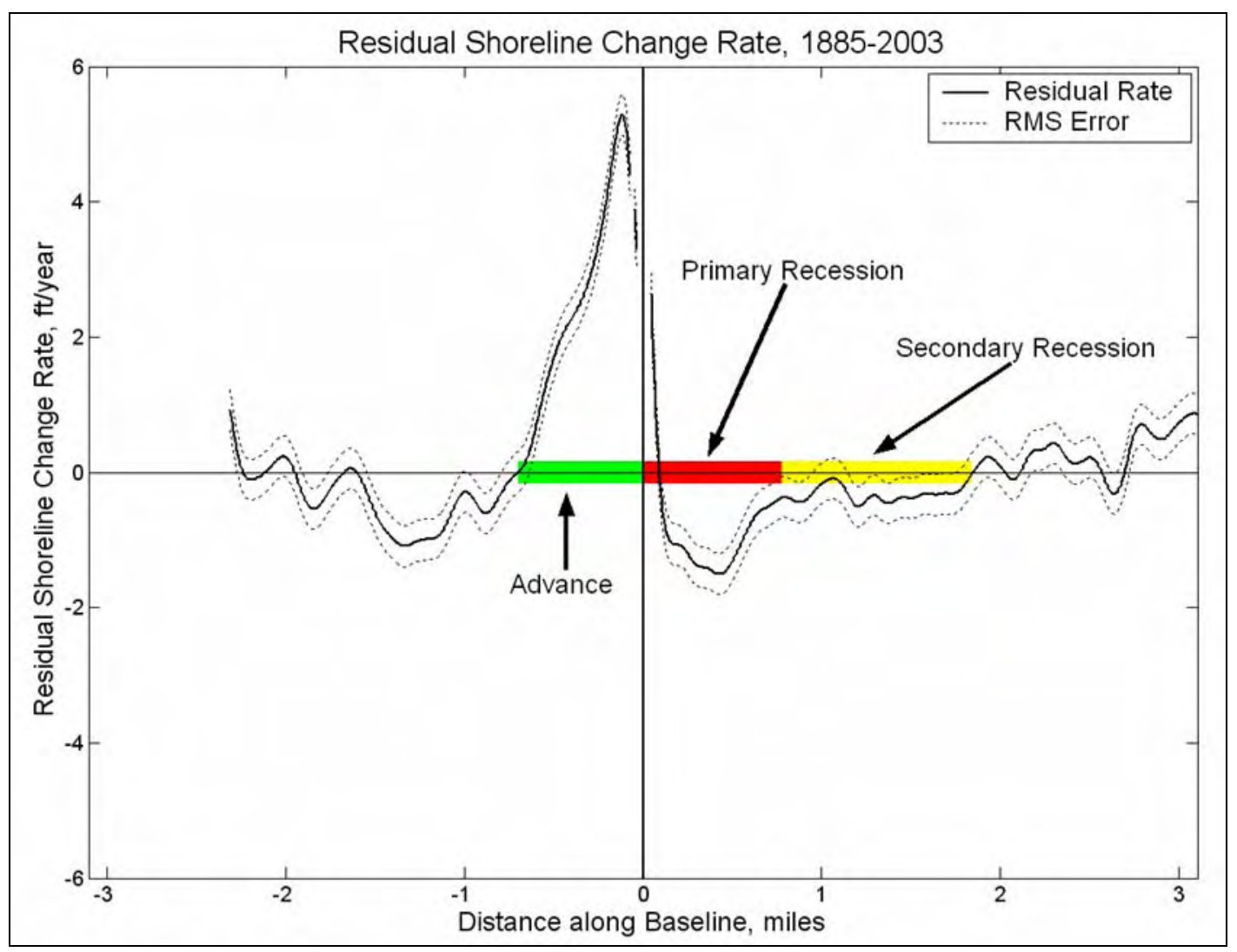

Figure 24. Residual shoreline change rate in vicinity of Mattituck Inlet, 1885 to 2003

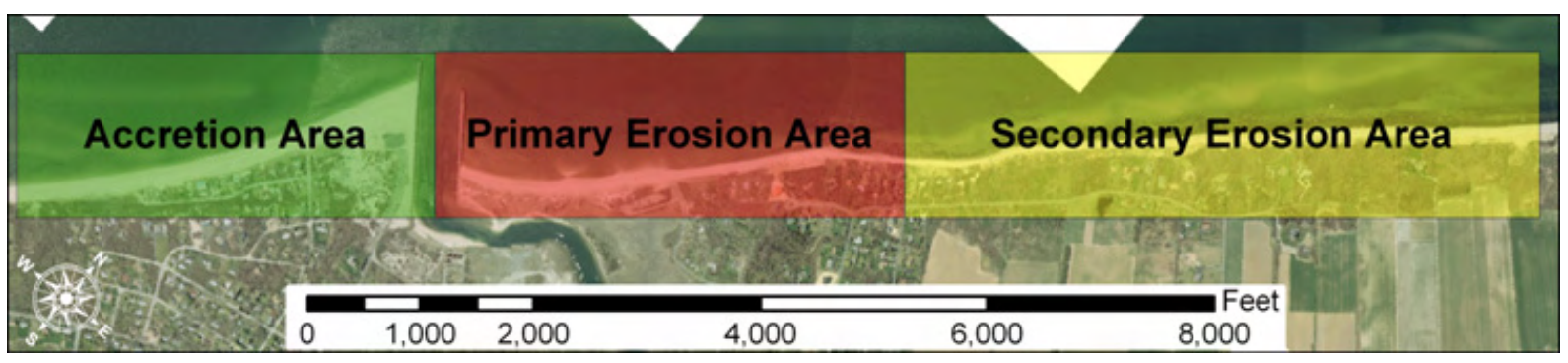

Figure 25. Areas of shoreline advance and recession overlaid on year 2000 aerial photography

\section{Long-term shoreline change rates}

The long-term shoreline change rate of the coast between Jacobs Hill and Duck Pond Point was evaluated to determine the impact of the Federal navigation project for the period 1885 to 2004. Long-term rates for the updrift and downdrift impact areas defined in the previous section were calculated by both the end-point and linear regression methods. Rates calculated for local shoreline segment are shown in Figure 26, and change rates for the impoundment and recession zones are compiled in Table 11. The 2003 shoreline is shown in Figure 26 to provide description of shoreline changes to Jacobs Hill. The overall signal is similar to the 1885 to 2004 interval. Shoreline recession was the predominant 
trend within the study area, with shoreline advance limited to sediment impoundment updrift the jetties at both Mattituck Inlet and Goldsmith Inlet.

End-point (EP) and linear regression rates (LR) compare well over the long term. The EP rates represent the total impact of the inlet on the adjacent shorelines, whereas the LR rates contribute toward verifying EP rates and also provide insight into intermediate processes. As expected, LR recession rates downdrift of the inlet are lower, representing the trend of decreasing recession rates during the past 20 years, which cannot be captured by the end-point rates (Figure 26). The LR rate demonstrates that establishment of sediment transport pathways across the inlet and improved management of dredged material have begun to mitigate shore recession downdrift of the inlet induced by sand trapping at the updrift jetty.

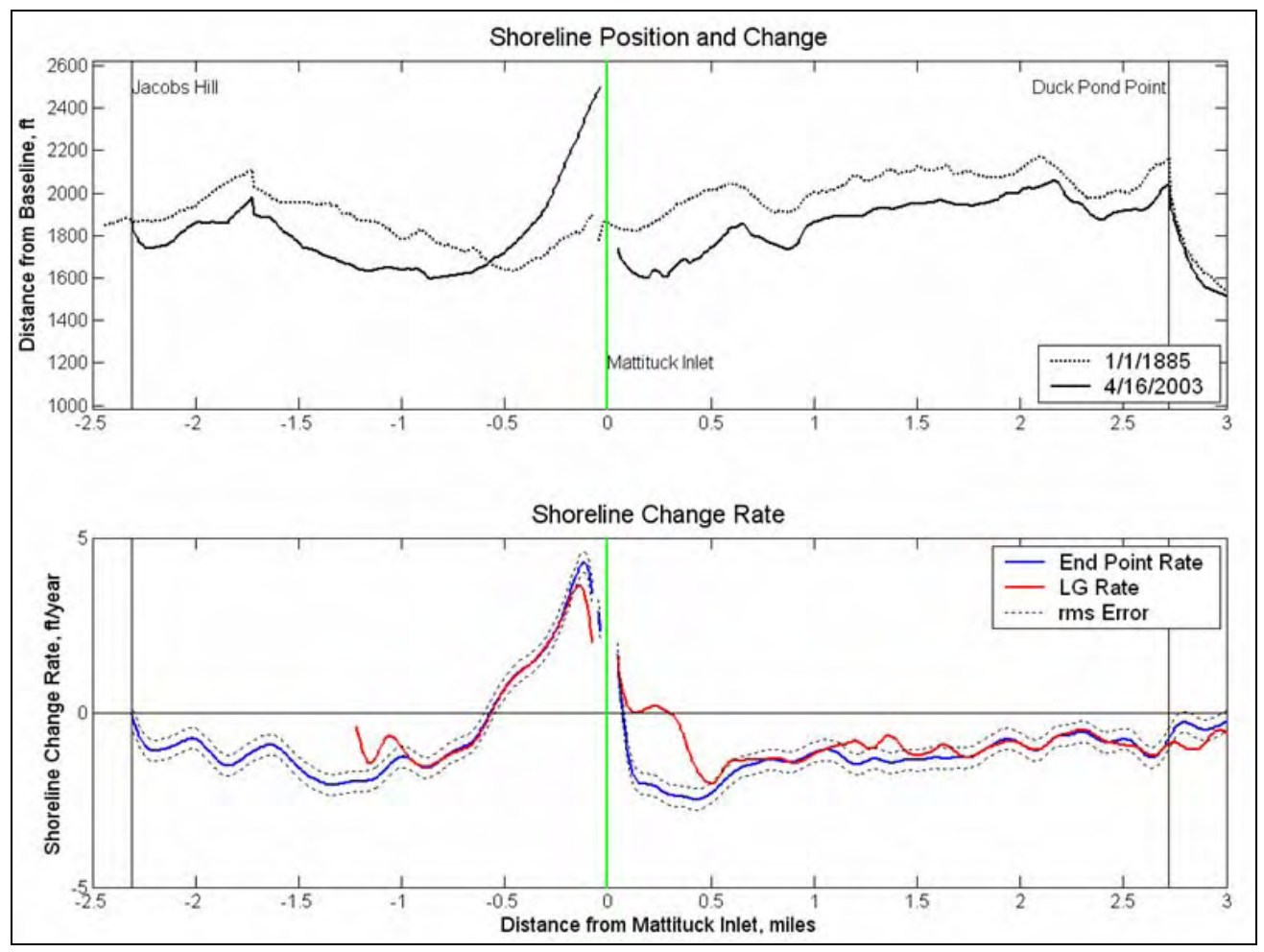

Figure 26. Local shoreline change, 1885 to 2003

\begin{tabular}{|c|c|c|c|c|c|}
\hline \multicolumn{6}{|c|}{$\begin{array}{l}\text { Table } 11 \\
\text { Long-Term Shoreline Change Rates, ft/year (1885-2004) }\end{array}$} \\
\hline Method & Updrift & $\begin{array}{l}\text { Primary } \\
\text { Recession } \\
\text { Area }\end{array}$ & $\begin{array}{l}\text { Secondary } \\
\text { Recession } \\
\text { Area }\end{array}$ & $\begin{array}{l}\text { Combined } \\
\text { Recession } \\
\text { Area }\end{array}$ & rms Error \\
\hline End-point & 1.8 & $\mid-1.7$ & $\mid-1.3$ & -1.5 & 0.4 \\
\hline Linear Regression & 1.4 & -1.0 & $\mid-1.1$ & -1.0 & 0.4 \\
\hline
\end{tabular}




\section{Summary}

Long-term regional background shoreline recession rates were calculated to determine the response of adjacent shorelines to the Federal navigation project at Mattituck Inlet. A long-term background recession rate of $1 \mathrm{ft} /$ year was calculated for the 30-mile reach from Mt. Sinai Harbor to Horton Point between 1885 and 2001. Previous studies document this systematic regional recession.

Shoreline change rates were determined for both successive intervals and end-members between 1885 and 2004. The shoreline change signal in the vicinity of Mattituck Inlet prior to 1955 was dominated by shoreline advance west of the inlet and recession east of the inlet, induced by trapping of sediment updrift of the west jetty. After 1955, the shoreline change signal became variable, reversing from advance to recession between 1955 and 1976. Variability was attributed to commercial mining of material from the impoundment fillet west of the inlet and construction of jetties in Northville at Jacobs Hill. Decreasing shoreline recession rates downdrift of the inlet in the 1990s may indicate maturation of the shoreline equilibrium planform.

The long-term regional recession rate was removed from the local long-term rate to yield a residual shoreline recession rate. The residual rate allowed delineation of the extent of shoreline advance to the west of the inlet, and recession to the east of the inlet. Sediment trapping at the updrift jetty created an impoundment fillet (shoreline advance) extending for approximately 3,500 ft to the west of the inlet. The average rate of shoreline advance in this area was $1.8 \mathrm{ft} /$ year (1885 to 2004). Two distinct areas of shoreline recession were identified downdrift, extending for approximately $9,600 \mathrm{ft}$ to the east of the inlet. The primary recession area extends for $4,000 \mathrm{ft}$ to the west, with average recession rate of $1.7 \mathrm{ft} /$ year; the secondary recession area extends for another $5,600 \mathrm{ft}$, with a lower average rate of $1.3 \mathrm{ft} /$ year $( \pm 0.4 \mathrm{ft} /$ year $)$. 


\section{Hydrodynamic and Sediment Transport Modeling}

This chapter describes numerical simulations performed to examine the circulation within Mattituck Creek and the sediment transport pathways at the entrance to the inlet. The objective of the circulation study was to determine if dredging of the relatively large shore-attached flood shoal feature, located on the north sides of the inlet, would increase water movement along the creek. The dredged material would be placed on the downdrift beach as part of channel advance maintenance and erosion mitigation (Alt 3 described in Chapter 7). The sediment transport modeling was performed to gain understanding of sediment pathways, particularly on natural bypassing, and dependence of sediment transport pathways on grain size at this site with widely varying surficial sediments ranging in size from sand to gravel.

\section{Circulation Modeling}

As part of a CIRP study on morphologic processes at Mattituck Inlet, Morgan et al. (2005) established the regional finite-element circulation model ADCIRC (Luettich et al. 1992) for the site to examine water level and current produced by the astronomical tide. They demonstrated that the model reproduced water-level measurements at representative locations around the perimeter of Long Island Sound, and that calculations agreed with measurements of water level and current made at Mattituck Inlet and Mattituck Creek in October 2002. Figure 27 shows coverage of the ADCIRC regional grid, which allows calculation of tidal circulation at the study site with rigorous boundary conditions. Figure 28 shows detail of the ADCIRC calculation grid in the vicinity of the inlet and in Mattituck Creek, refined as part of the present study. Grid resolution was increased to improve representation of the flood shoals and additional calculation points in the creek. 


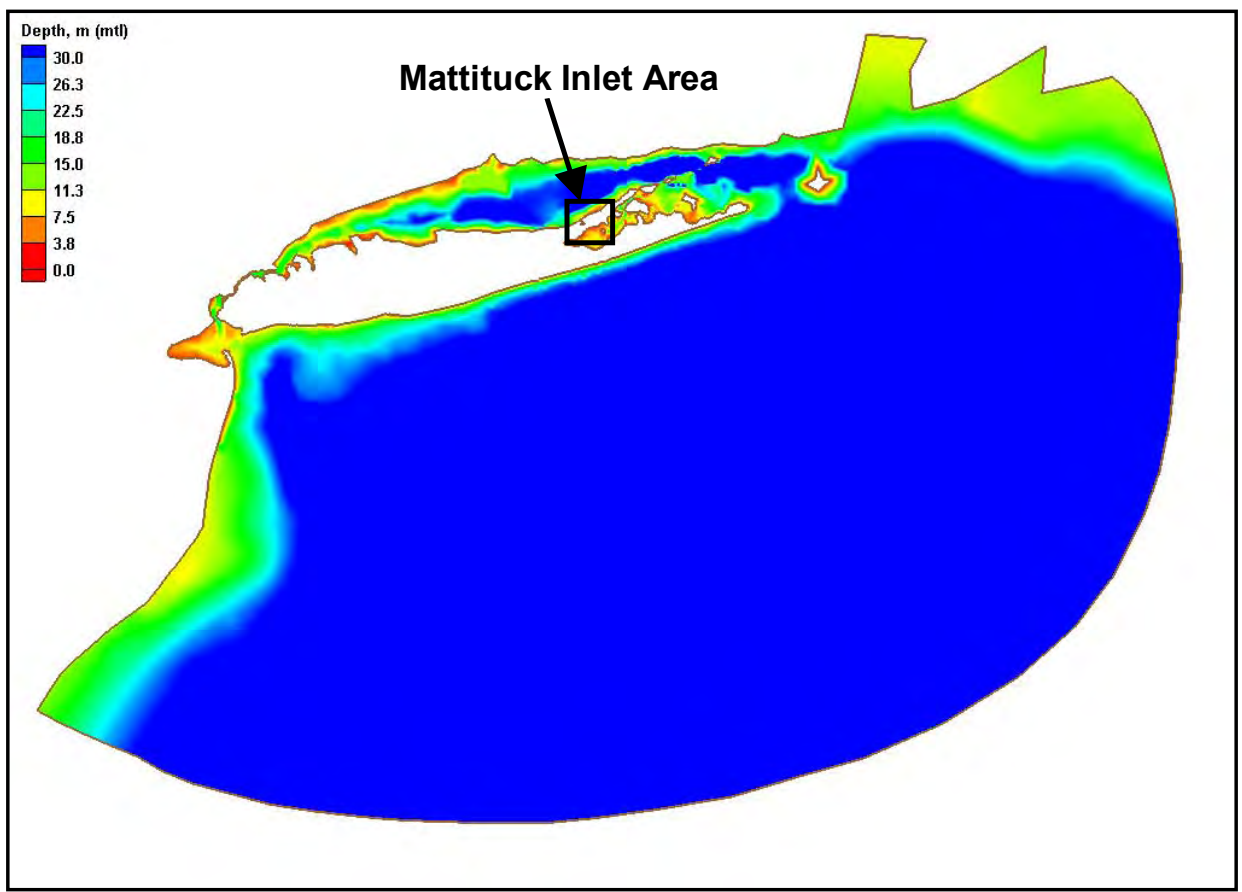

Figure 27. ADCIRC grid for Mattituck Inlet and location of site

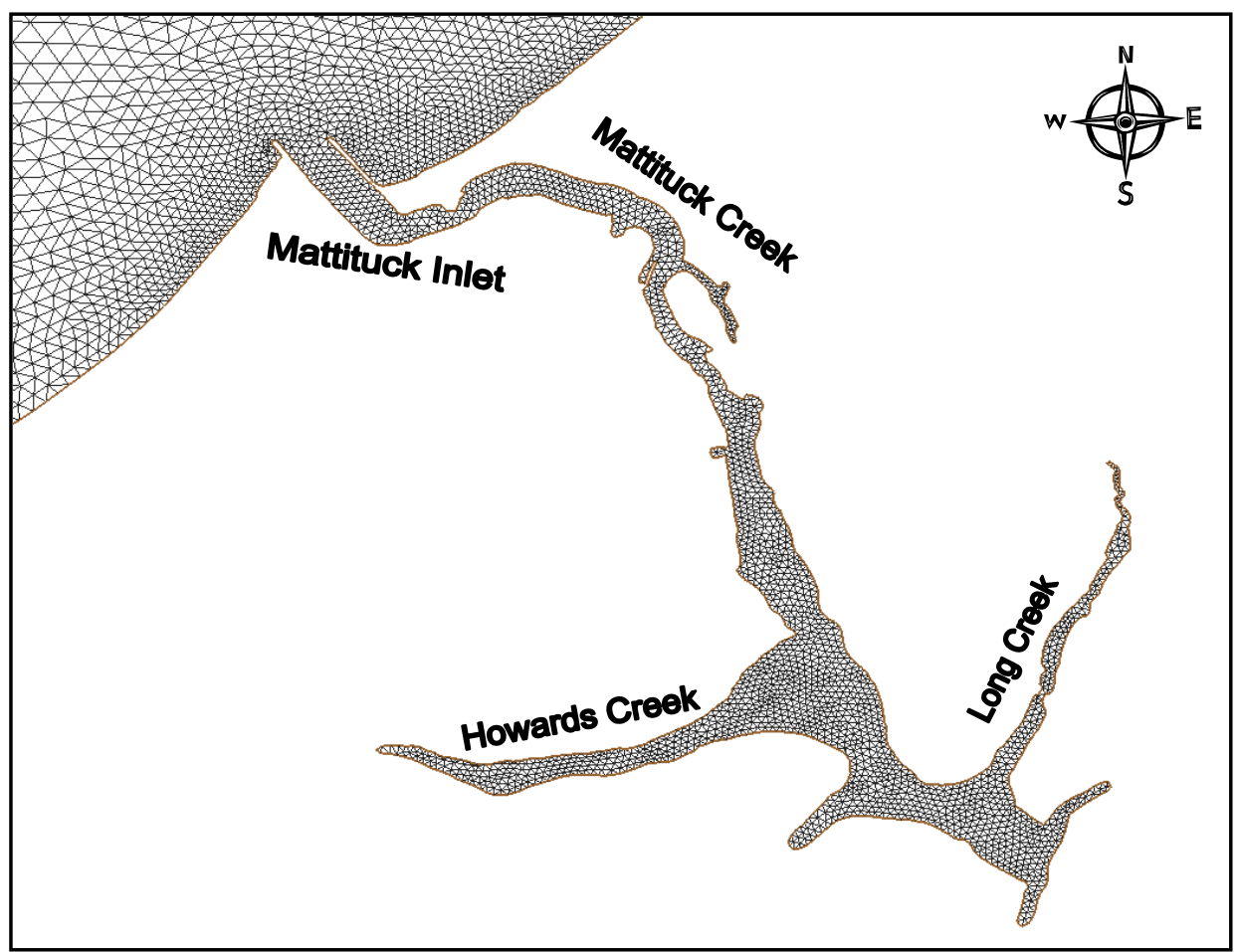

Figure 28. ADCIRC node structure at Mattituck Inlet and Mattituck Creek 
The calculated current velocity was evaluated at four stations, labeled as sta 1 to sta 4 in Figure 29. Current speed was evaluated, which is the magnitude of the vector current.

As a possible environmental enhancement to promote circulation, approximately $14,500 \mathrm{cu}$ yd of material was removed from the numerical grid representing the north flood shoal, a prominent morphologic feature that tends to protrude southward and into Mattituck Creek, as shown in Figure 30. In the extraction, sediment was taken from 1.5-3-ft depth along the shore to approximately 9-ft depth mean tide level toward the channel. As described by Morgan et al. (2005), much of the material that created this feature likely originated from sediment that entered through the 1935 breach at the landward side of the east jetty. The jetty was subsequently lengthened $280 \mathrm{ft}$ landward. The breach occurred at the end of the jetty and was oriented approximately eastwest, not north-south or through the barrier island. Waves and flood current then transported a portion of this material southward into the entrance. This material was then further transported eastward to form the presently observed feature.

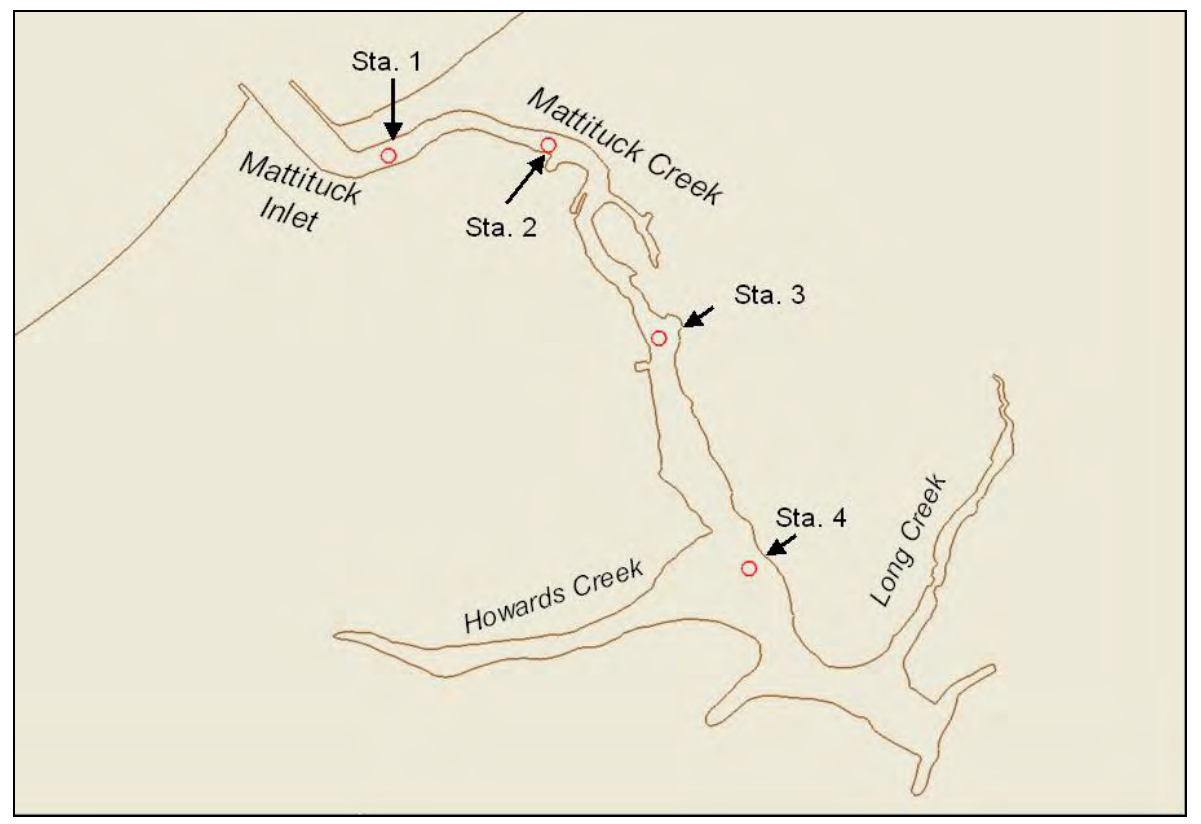

Figure 29. Location of the four speed comparison points

The calibrated ADCIRC model was run for the 30-day time interval from 19 September to 19 October 1996, for which hindcast wave information was available for combined wave, circulation, and sediment transport modeling described in the next section. In the present section, only tidal circulation is discussed, because waves do not penetrate to Mattituck Creek. Discussion is first made of the horizontal circulation patterns at spring tide for the existing condition and the dredged condition (north flood shoal removed) to obtain an overall comprehension of the change in current velocity and where it occurs. 


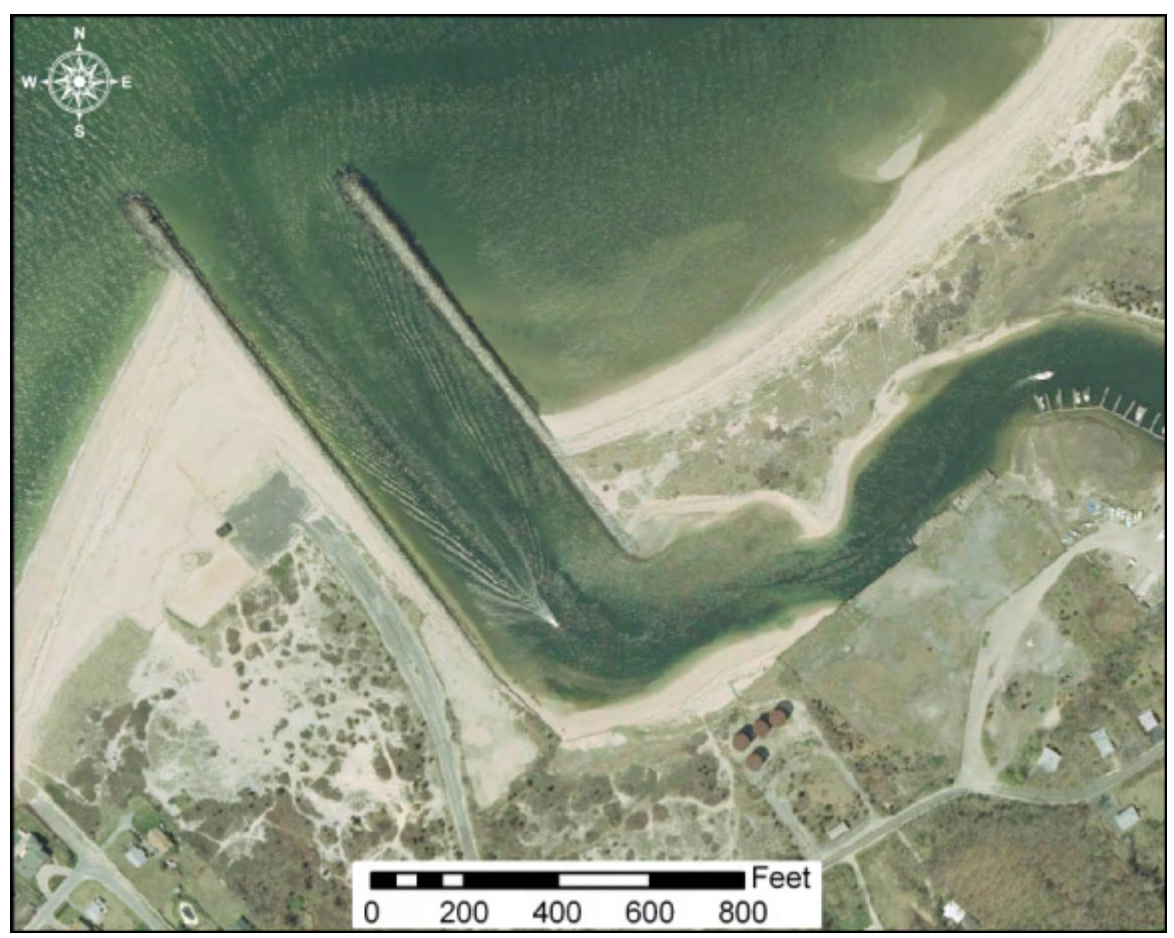

Figure 30. North flood shoal protruding into Mattituck Creek, 15 April 2004

\section{Horizontal Circulation Patterns}

Spring tide range at Mattituck Inlet approaches $2 \mathrm{~m}$. Despite this, the tidal current through the entrance of Mattituck rarely exceeds $0.5 \mathrm{~m} / \mathrm{sec}$ because of the large cross-sectional area of the inlet channel (Morgan et al. 2005). Therefore, a maximum current velocity in Mattituck Creek is not expected to exceed $0.5 \mathrm{~m} / \mathrm{sec}$ as an approximation to the order of magnitude expected. Figures 31 and 32 compare the ebb current at the maximum spring tide for the calculation interval for the existing condition and dredged flood shoal condition, respectively, and Figures 33 and 34 display a similar comparison for the maximum flood tide.

For both flood tide and ebb tide, removal of the flood shoal decreases the current in the vicinity of the shoal, where Mattituck Creek first turns east from the entrance, because the volume of water in the channel increases in that region. For both flood and ebb tide, circulation is improved (increases) as far as Howard Creek and into Long Creek if the flood shoal is removed. The current is stronger because removal of the north shoal opens the channel near the origin of tidal forcing at the inlet entrance and decreases bottom and side-channel friction to the flow.

Time series of current speed at the four stations are plotted in Figures 35 to 38. At sta 1, there is a notable decrease in current velocity throughout the tidal cycle with the flood shoal dredged because the volume of water increases in that area. The discharge or volume rate of water remains the same or slightly increases because of reduced friction in the dredged channel. At the other stations, it is difficult to discern changes between the existing and dredged-shoal 
condition. Inspection of the data at higher resolution indicates that the current typically increases slightly for the dredged-shoal condition.

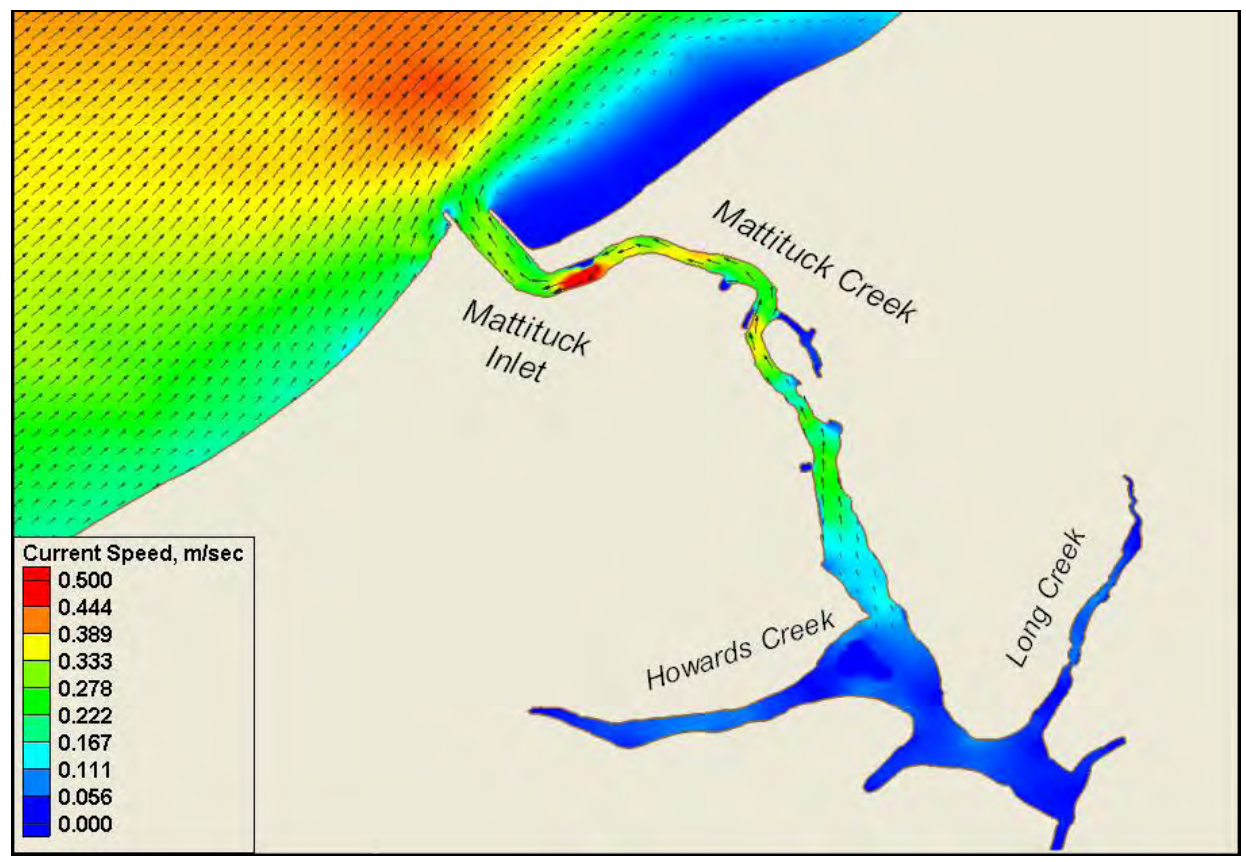

Figure 31. Existing condition: plan view of maximum spring tide ebb current

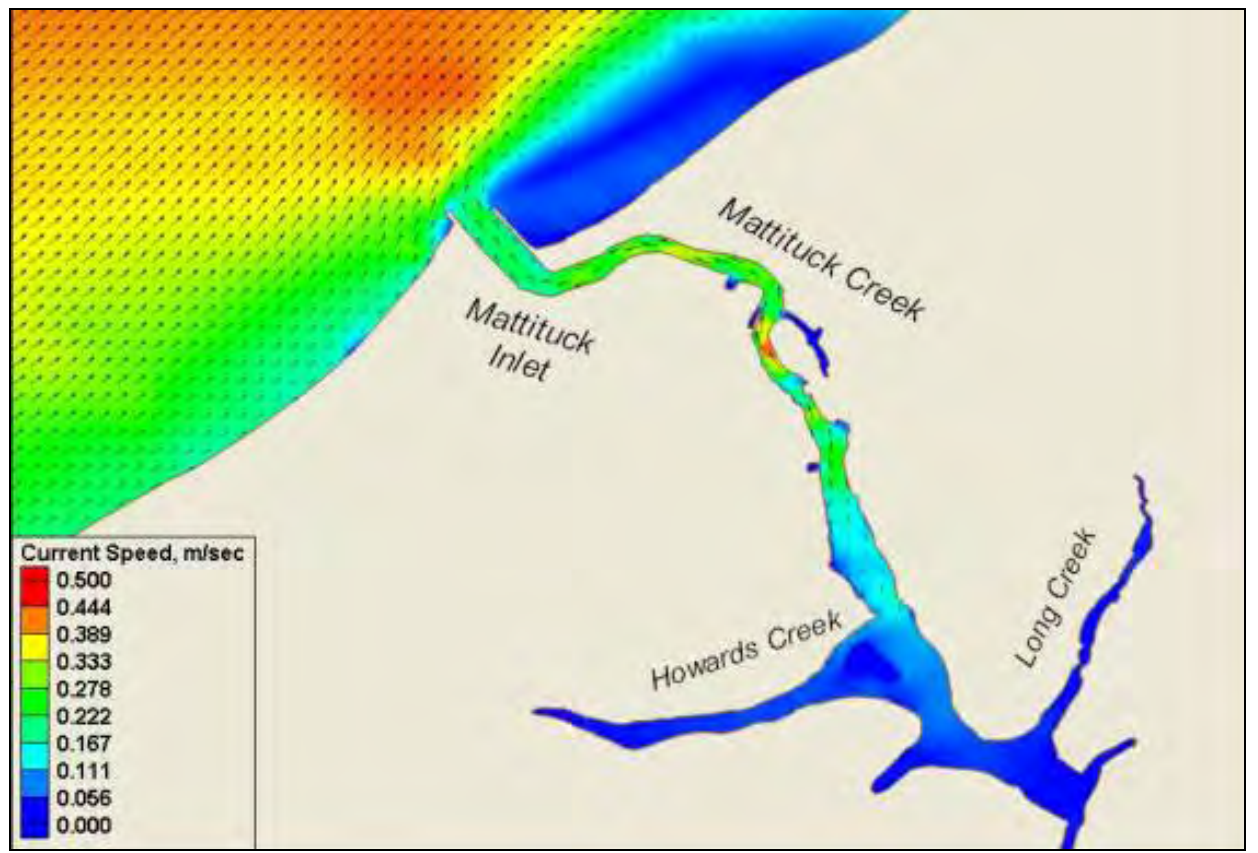

Figure 32. Dredged flood shoal: plan view of maximum spring tide ebb current 


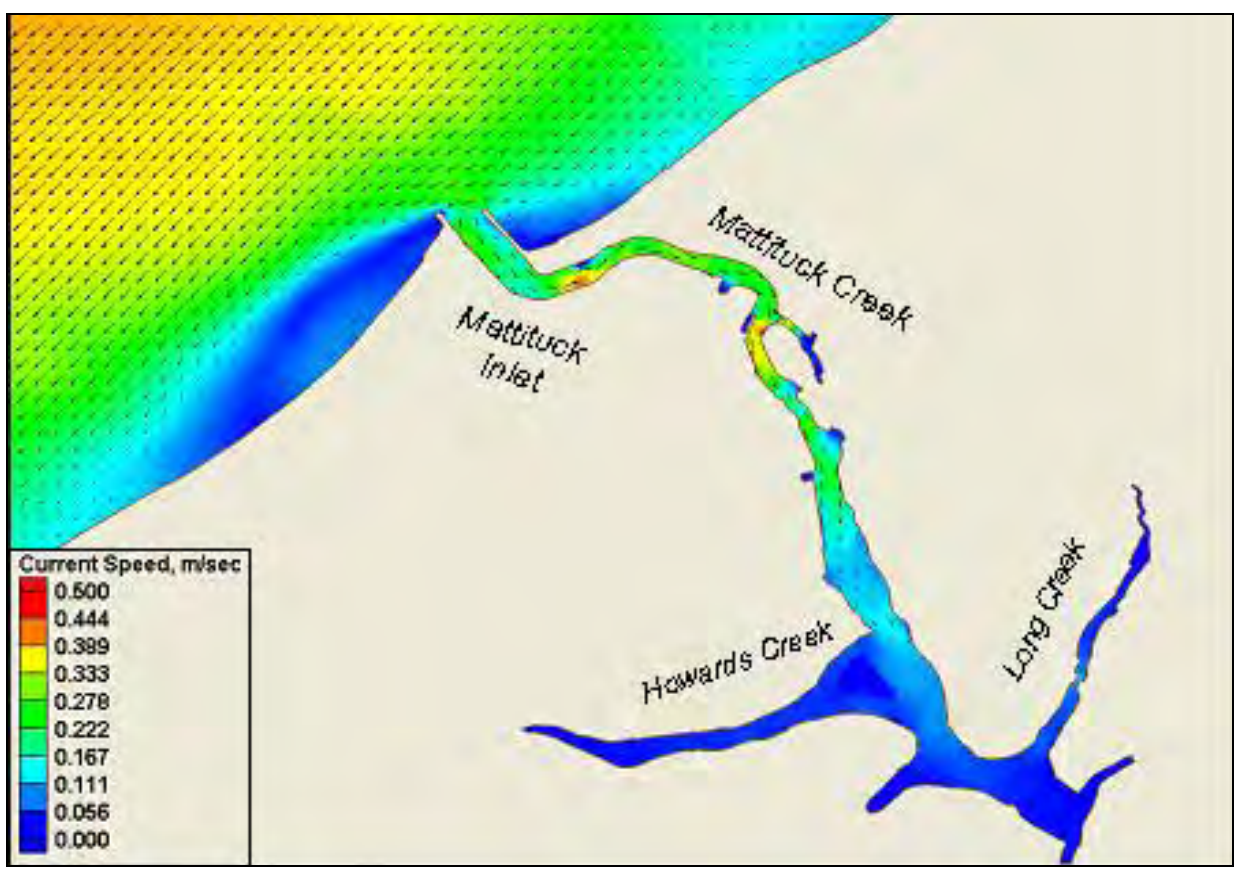

Figure 33. Existing condition: plan view of maximum spring tide flood current

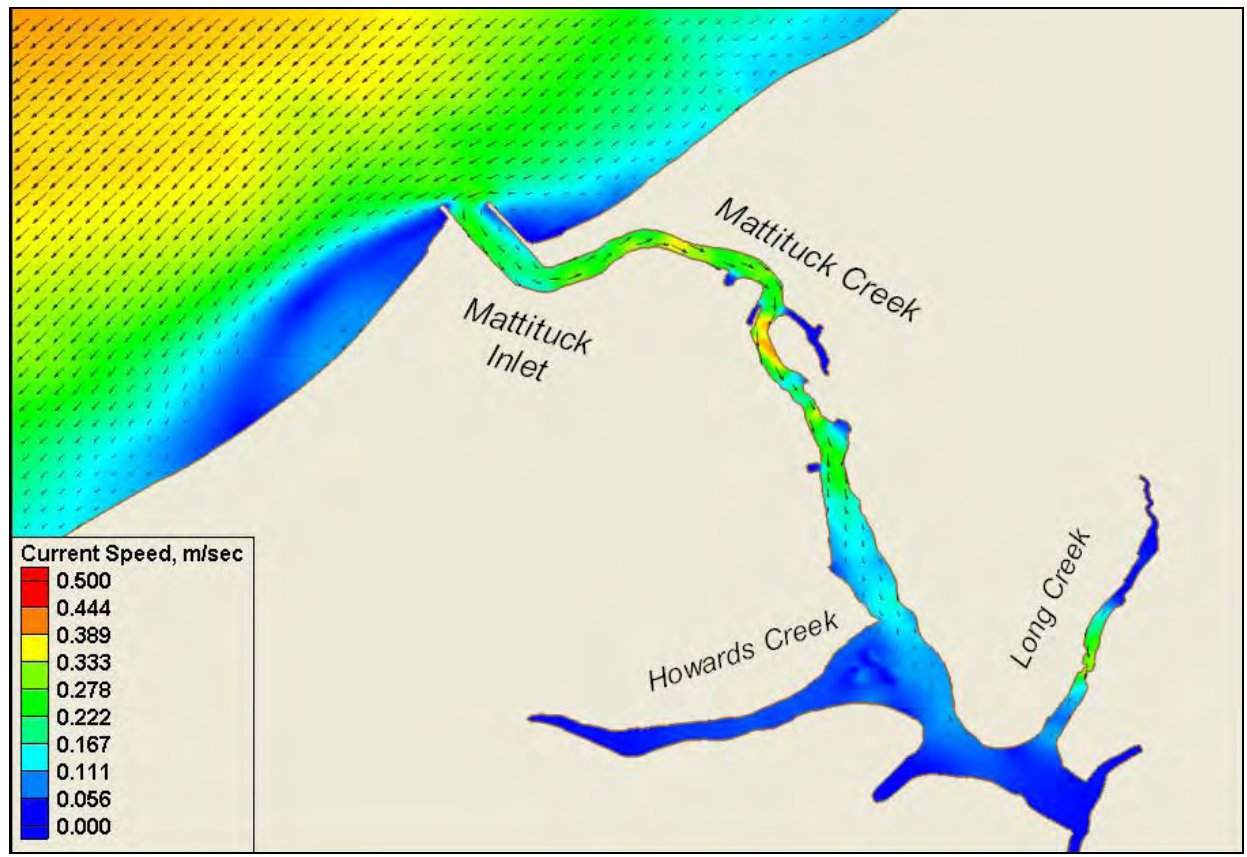

Figure 34. Dredged flood shoal: plan view of maximum spring tide flood current 


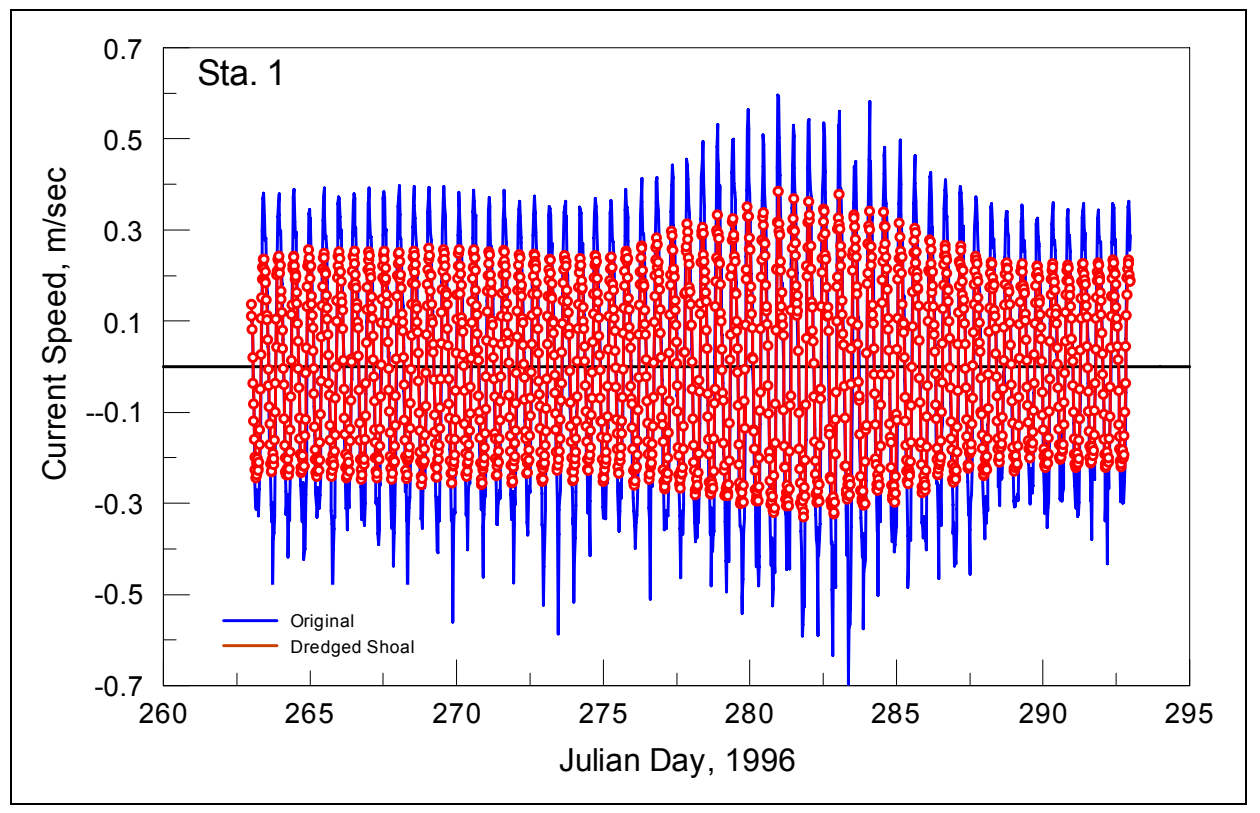

Figure 35. Speed comparison of alternatives, sta 1

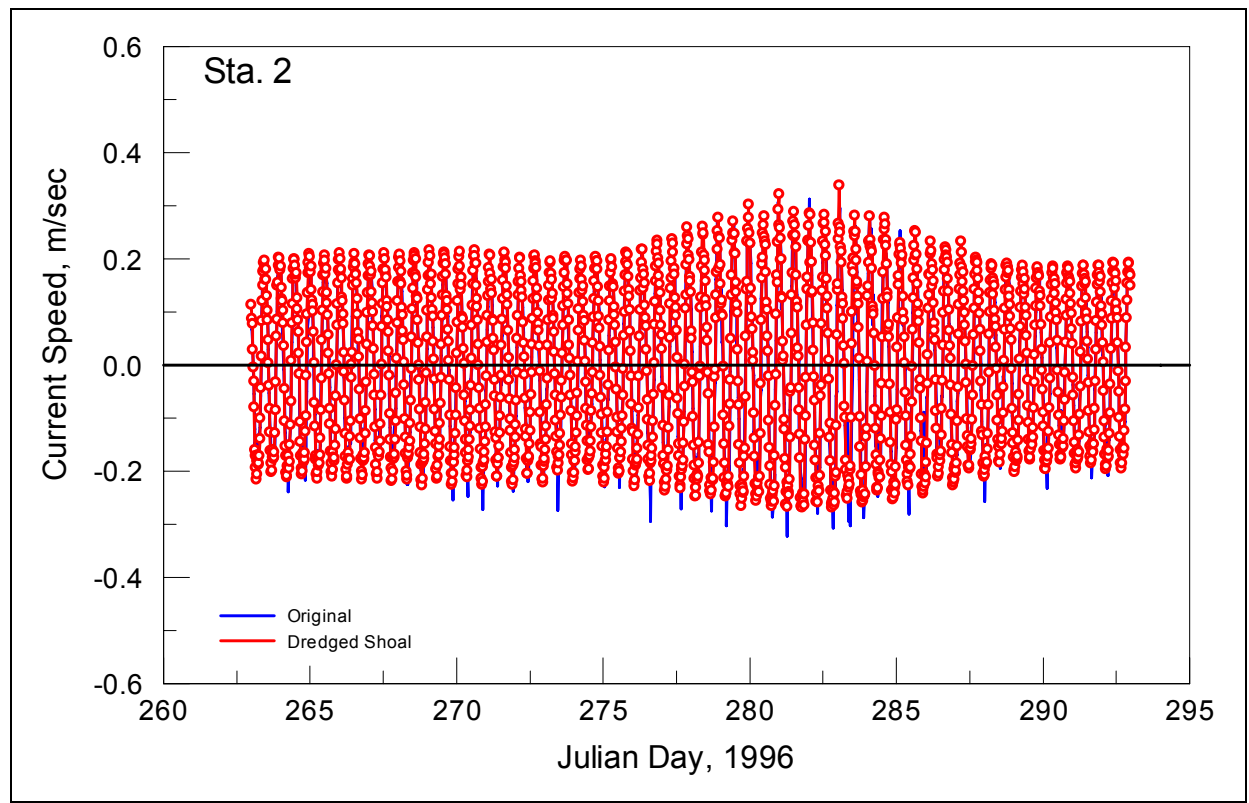

Figure 36. Speed comparison of alternatives, sta 2 


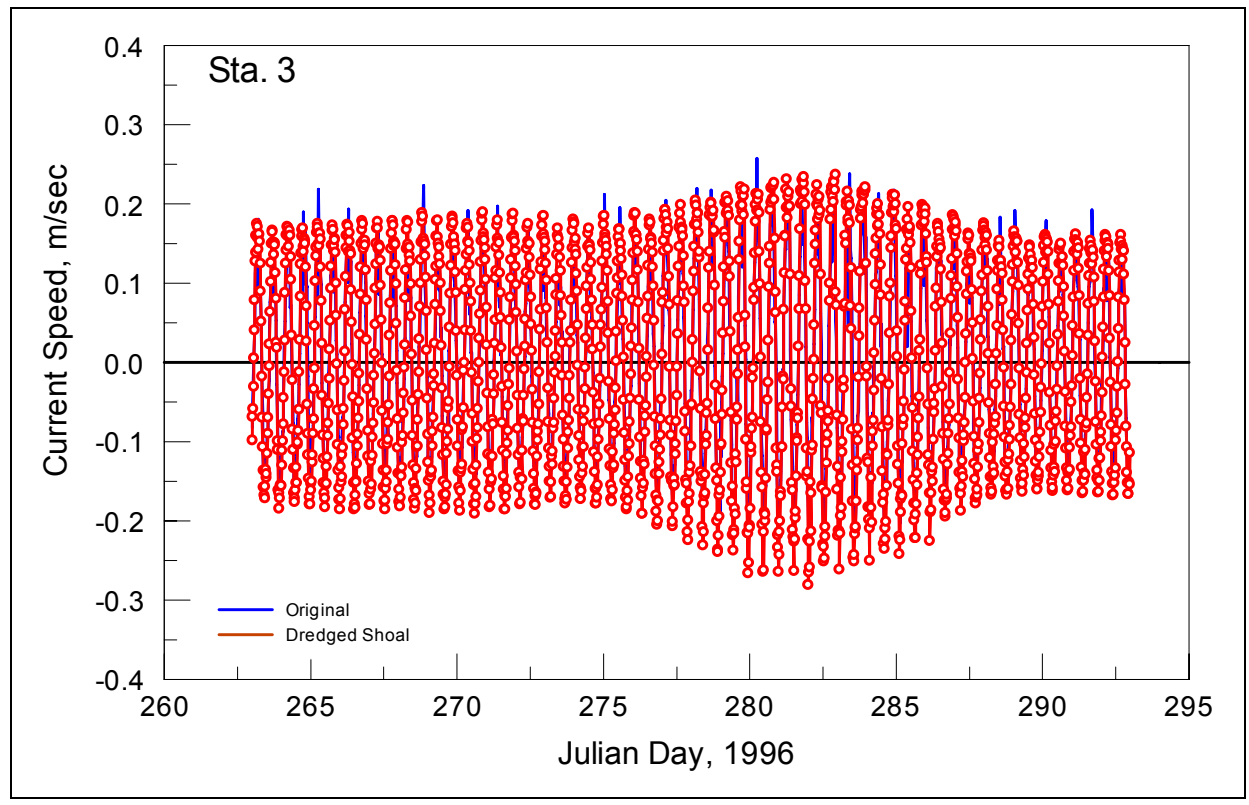

Figure 37. Speed comparison of alternatives, sta 3

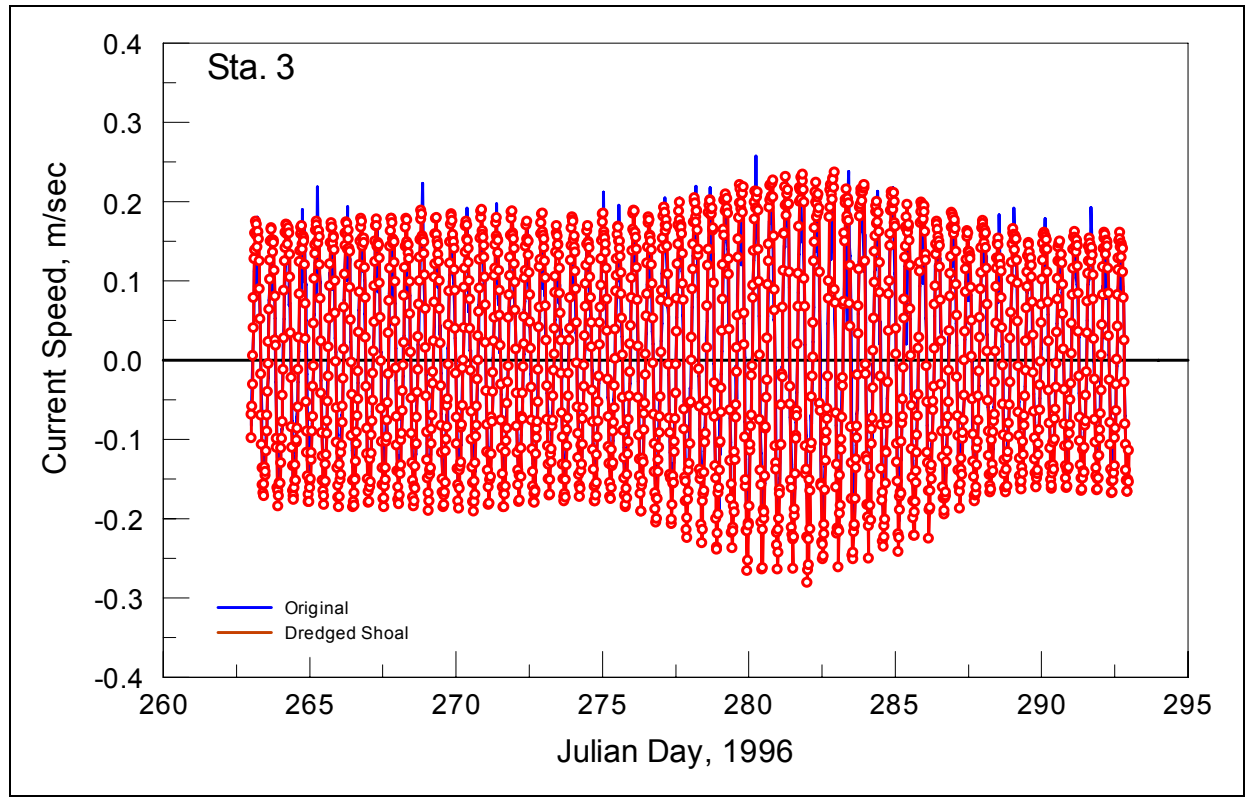

Figure 38. Speed comparison of alternatives, sta 4 
The water surface along Mattituck Creek moves up and down uniformly because the length of the creek is much shorter than that of a tidal wave.

Therefore, water level at sta 4 is representative of that elsewhere along the creek. Calculated water level for the existing condition and for the condition with the flood shoal dredged are shown in Figure 39. The existing condition is plotted as a faint-colored line to show that the water level with the flood shoal dredged achieves greater maxima and minima, that is, the tidal range increases by about $2-4 \mathrm{~cm}$ for the dredged-shoal condition. Slightly increased tidal range and increased current velocity in the back of the creek would act to enhance water circulation and exchange.

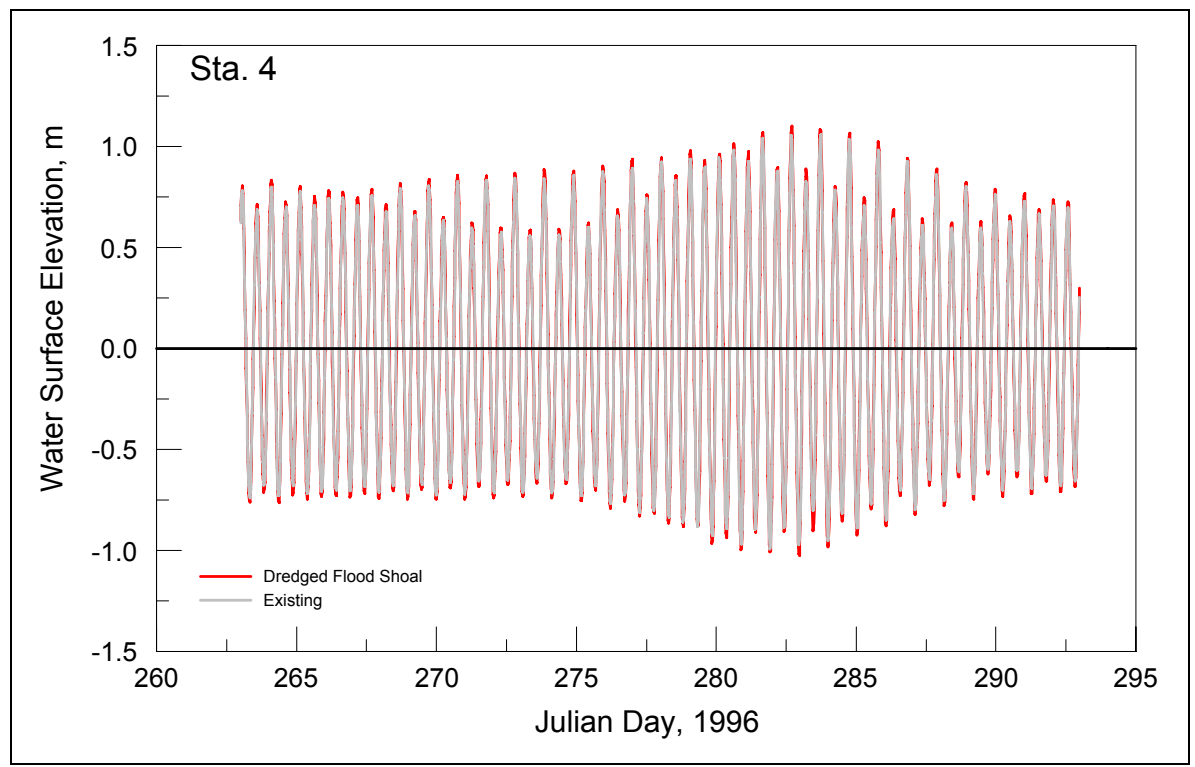

Figure 39. Comparison of calculated water levels, sta 4

\section{Sediment Transport Pathways at Entrance}

The Inlet Modeling System (IMS) M2D version was established at the entrance of Mattituck Inlet to examine sediment transport pathways produced by combined wave-induced and tidal currents. IMS-M2D is a finite-difference model that is convenient to operate and computationally efficient at the scale of small projects such as a single inlet (Militello et al. 2004). Water-surface elevation tidal forcing at the boundaries of IMS-M2D was supplied by saved output from the ADCIRC regional model. The model was also forced by radiation stresses from the transformation of breaking waves, calculated with the wave model STWAVE (Smith et al. 2001). In the nearshore and at an inlet entrance, the wave-induced circulation is the principal driver of the longshore current and associated longshore sediment transport, entry of sediment to the inlet channel, and sediment bypassing around the inlet. 
Wave information, in general, and wave directional data, in particular, are lacking for the Long Island Sound. Wave information for the 30 days from 19 September to 19 October 1996 was extracted from a 4-year hindcast performed by OCTI that was made available to this study ${ }^{1}$. This time interval was selected to represent higher waves that would transport sediment to the east, the predominant direction of transport at the site (Chapter 1). The hindcast was performed for studies at Goldsmith Inlet, located $8 \mathrm{~km}$ to the east of Mattituck Inlet. Offshore wave conditions are expected to be the same at the two sites. The offshore wave time series were then input to STWAVE at 3-hr interval.

The IMS-M2D grid for Mattituck Inlet is shown in Figure 40. High resolution was specified alongshore and through the inlet. The model consisted of 13,020 active cells ranging in dimensions from 15 by $20 \mathrm{~m}$ to 50 by $100 \mathrm{~m}$. The encompassed area is about $35 \mathrm{~km}^{2}$. The simulation time was 1 month.

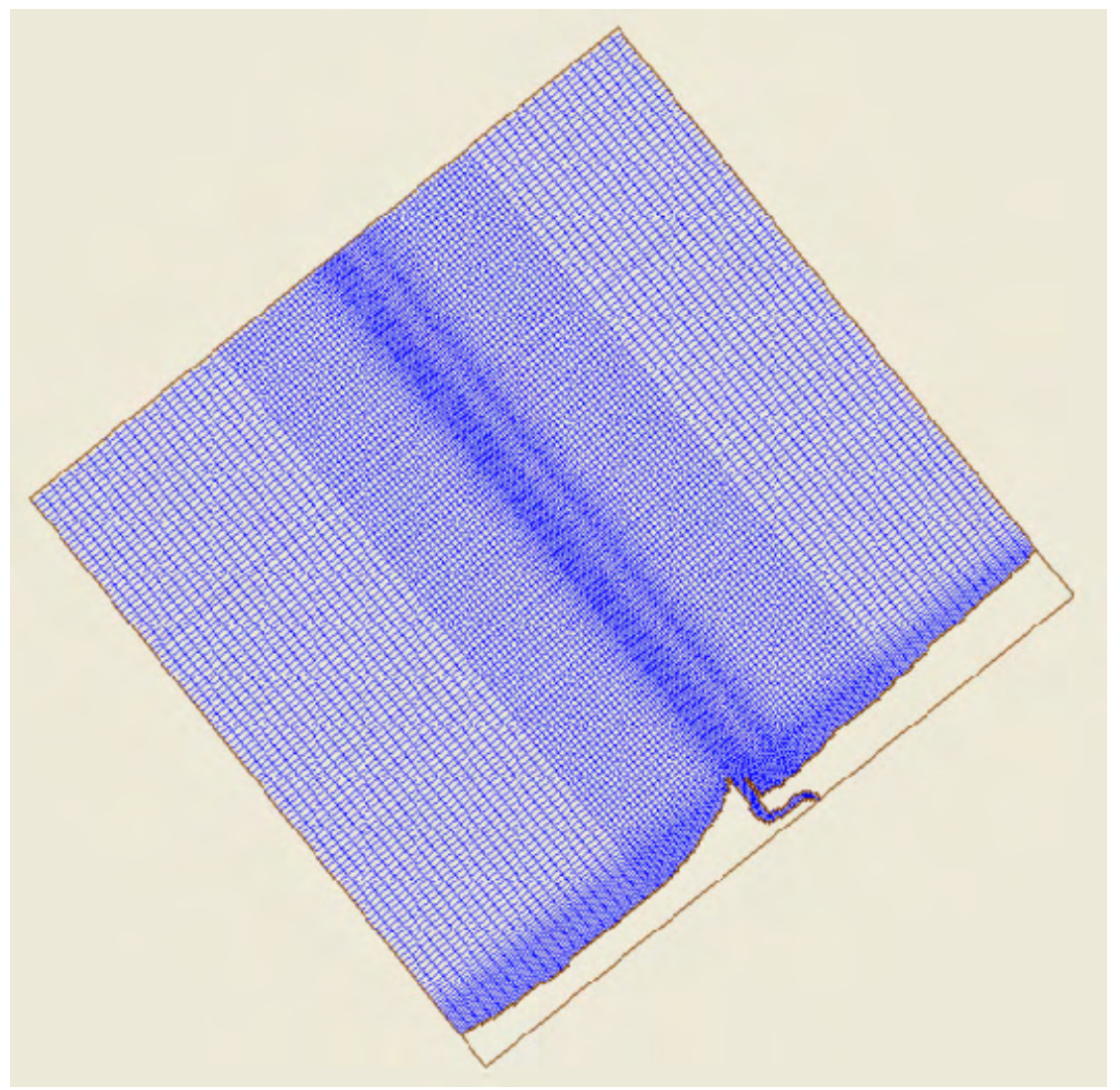

Figure 40. IMS-M2D grid showing high resolution at Mattituck Inlet

Sediment transport under combined waves and currents was calculated with the Watanabe (1987) total load formula, a type of velocity-cubed (power) or Meyer-Peter Muller equation. Two sediment grain sizes were specified in independent runs, $0.2 \mathrm{~mm}$ to represent finer material in the littoral system, and

\footnotetext{
${ }^{1}$ Personal communication, 25 August 2004, Mr. William G. Grosskopf, Vice President, OCTI, Chadds Ford, PA.
} 
$0.6 \mathrm{~mm}$ to represent coarser material. The figures that follow were rotated $38 \mathrm{deg}$ from north for clarity of visual presentation in orienting the shoreline parallel to the bottom of the figure.

Calculated depth change at the Mattituck Inlet entrance for the 1-month period is displayed in Figures 41 and 42 for the 0.2 and $0.6-\mathrm{mm}$ sand, respectively. Cooler colors denote deepening, and warmer colors denote shoaling. Both figures indicate development of a shoal at the entrance, protruding from west to east. Small changes in depth along the shoreline should be ignored as being an artifact of grid resolution and the available bathymetry not being in equilibrium with the wave conditions run for the particular simulated month.

Greater depth change occurs for the finer sediment, as expected. Maintenance dredging at Mattituck Inlet is required at the entrance, indicating these results are in qualitative agreement with dredging practice. The calculations show that finer sediments can bypass the entrance from west to east, and that some lesser amount of coarser material may bypass as well. The predominant predicted morphologic change is shoal encroachment into the channel from west to east, and deposition into the channel. As discussed by Morgan et al. (2005), the inlet cross-sectional area is about one-third larger than empirical formulas predict, so a predicted tendency for channel infilling at the entrance is a reasonable consequence. A small scour hole is predicted at the tip of the east jetty, but survey data are not available for verification.

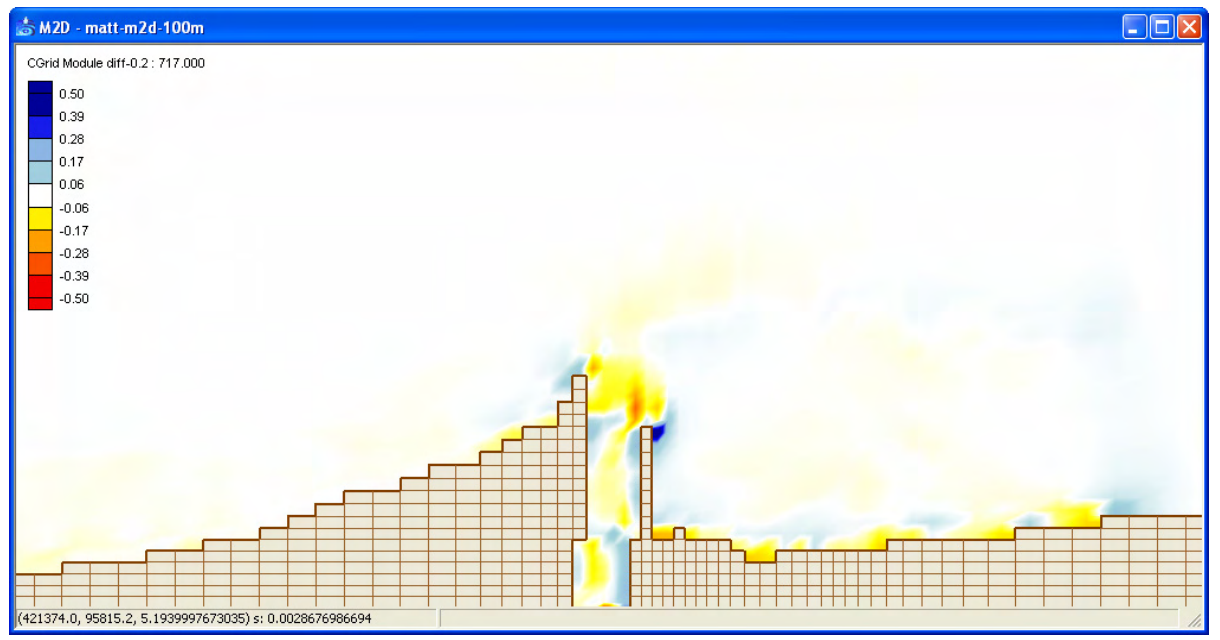

Figure 41. Calculated depth change after 1 month, $0.2 \mathrm{~mm}$ sand

Calculated depth change over 1 month for the 0.2-mm sediment from the entrance through the turn eastward to Mattituck Creek is displayed in Figure 43. This figure is a wider area view of Figure 41. Substantial deposition is observed on both the north and south sides of the channel bend, in qualitative agreement with observed shoal development at the site. 


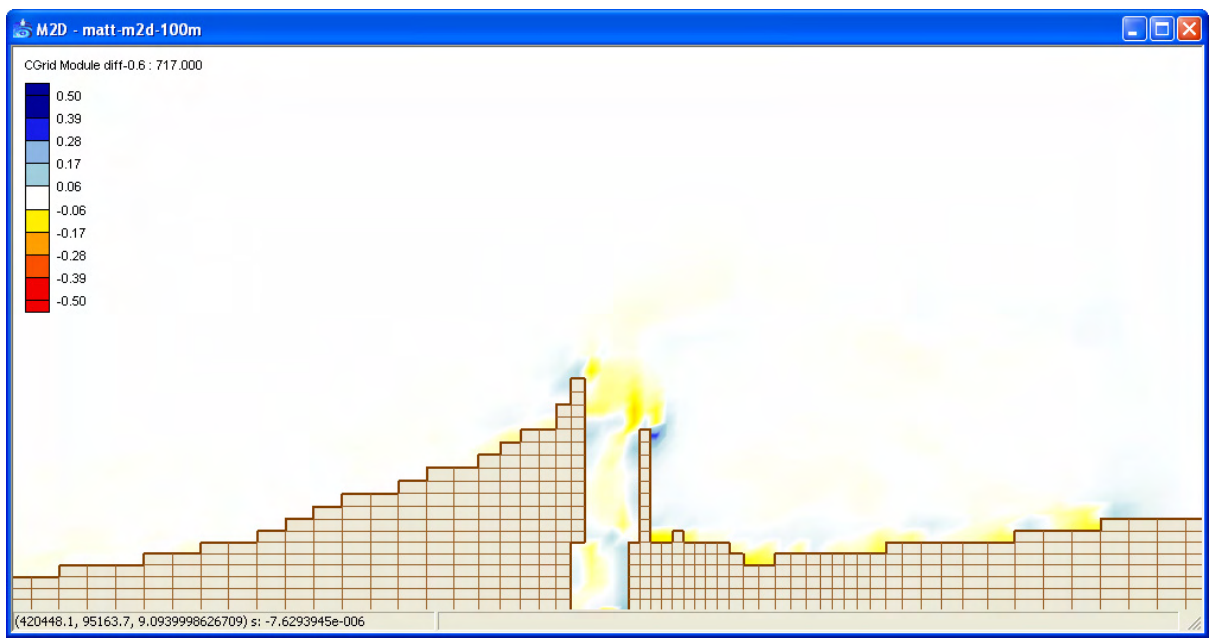

Figure 42. Calculated depth change after 1 month, $0.6 \mathrm{~mm}$ sand

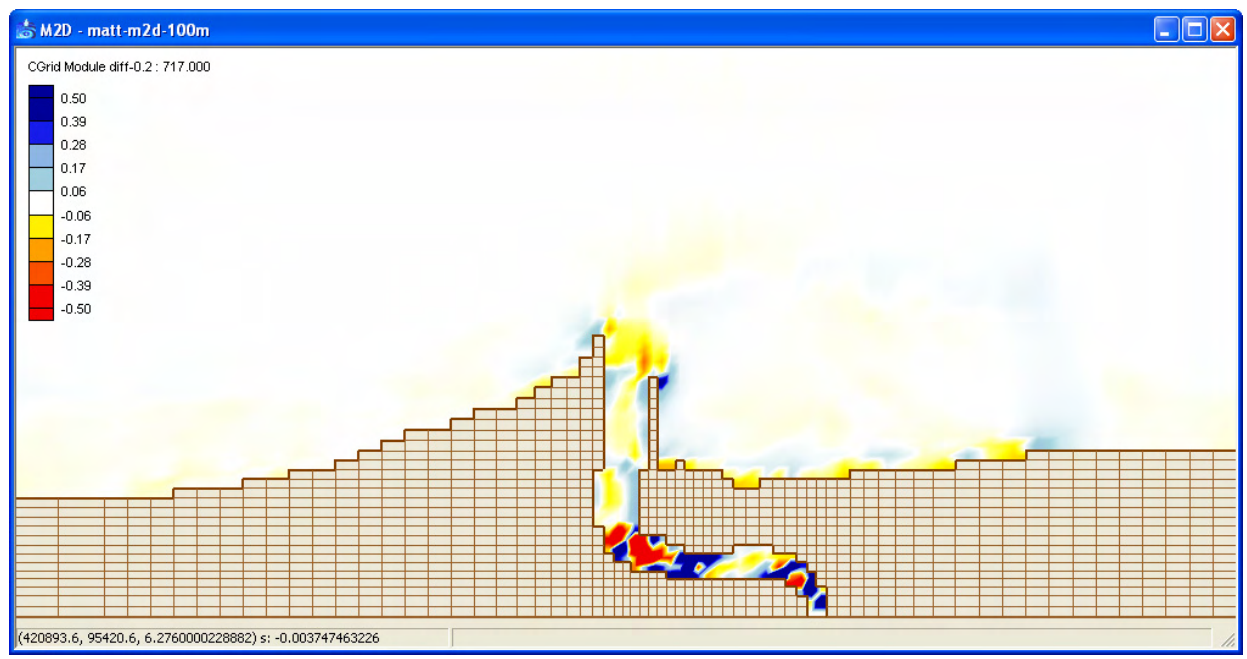

Figure 43. Calculated depth change after 1 month, $0.2 \mathrm{~mm}$ sand, including flood shoal area

In summary, calculations with the IMS-M2D model are in accord with documented dredging practice in predicting shoal formation at the entrance and in the channel near the bend to the east, where a flood shoal is present on both the north and south sides of the channel. The shoaling pattern at the entrance indicates that a small amount of material bypasses the channel from west to east. Logically, it is expected that this bypassing would increase in time as the channel fills between dredging events (Kraus and Larson 2003). As the shoal elongates eastward, the rate of bypassing will increase. It is difficult to quantify this process in the absence of directional wave data for the site. 


\section{Sediment Budget}

A sediment budget represents a tallying of sinks and sources of sediment within a littoral cell over a given period (Rosati and Kraus 1999a). Littoral compartments, or cells, are defined between natural or anthropogenic boundaries to longshore sediment transport, or at localized areas of erosion and deposition. Sediment budgets are formulated to identify sediment pathways, the magnitude of sediment transport along these pathways, volumetric change within cells, and the fate of sedimentary material.

Although several authors have studied shoreline recession (New York District 1969; USACE 1971; Davies et al. 1973), sediment impoundment at structures (Omholt 1974; Leatherman et al. 1997; Fields et al. 1999), and sediment supply from the erosion of bluffs (Davies 1972; Tanski 1981) at the study site, a quantitative sediment budget had not been compiled for the north shore of Long Island prior to the present study. This lack is probably due to several unknowns existing in the study area, in particular, on directional wave information, longshore sediment transport rates, sand mining, contribution of beach sediment from eroding bluffs, and the fate of littoral material. Sediment budgets formulated for the study area, especially on the regional scale, are limited by this lack of knowledge. Data sources available for this study are summarized in Table 12. This table also contains comments about quality and quantity of data.

\begin{tabular}{||l|l|l|l||}
\hline \hline \multicolumn{4}{|l||}{$\begin{array}{l}\text { Table } 12 \\
\text { Assessment of Sediment Budget Data Sources }\end{array}$} \\
\hline \hline Data Type & $\begin{array}{l}\text { Data } \\
\text { Quality }\end{array}$ & $\begin{array}{l}\text { Temporal } \\
\text { Coverage }\end{array}$ & Comments \\
\hline \hline Aerial photographs & Mixed & Good & None prior to 1930 \\
\hline Beach profile surveys & Excellent & Poor & $\begin{array}{l}\text { Limited coverage and questionable } \\
\text { positioning for 1969 profiles. Not } \\
\text { adequate for volumetric calculations }\end{array}$ \\
\hline Bluff supply rates & Good & Good & Quantitative \\
\hline Dredging data & Good & Good & Well documented \\
\hline Dredged material disposal & Fair & Fair & $\begin{array}{l}\text { Known after 1946, except for 1961 } \\
\text { dredging }\end{array}$ \\
\hline Sand mining at fillet & Poor & Poor & Documented from 1960-1975 only \\
\hline Sand mining from channel|| & Poor & Poor & $\begin{array}{l}\text { Commercial mining, some permits } \\
\text { available, volume undocumented }\end{array}$ \\
\hline Shoreline position & Excellent & Good & Limited between 1885 and 1955 \\
\hline \hline
\end{tabular}




\section{Background}

This section discusses sediment sources, sinks and longshore transport rates along the eastern north shore of Long Island.

\section{Sediment sources}

Along the north shore of Long Island, the major source of sediment is derived from bluff erosion (Davies et al. 1973; Tanski 1981). The north shore bluffs are composed of a heterogeneous mixture of unconsolidated sediments, with sand-sized grains as the major component. Tanski (1981) conducted comprehensive studies of bluff composition, recession, and sediment supply rates, studying bluffs between Mt. Sinai Harbor and Orient Point. On average, he found that sand composes 72 percent of the bluff by mass, with the gravel and silt/clay fraction composing 12 to 16 percent. Between Mt. Sinai Harbor and Orient Point, percentages of sand were higher, ranging from 90 percent to about 40 percent by mass for individual sections. All sections of bluff in this region were composed of more than 50 percent of sand except one ( 42 percent) near Orient Point. The percentage of gravel was considerably less than sand, but also quite variable, ranging between 5 and 35 percent. Values for silt and clay varied between 1 and 40 percent (Tanski 1981). Finer sediment quantities typically increased moving from west to east along the north shore coast (Fuller 1914; Tanski 1981).

Davies (1972) presents a stepwise description of bluff erosion along the north shore of Long Island. Long-term beach recession and elevated water level during storms lead to wave attack at the base of the bluffs, resulting in undermining, then mass slumping and eventually redistribution of material over the subaerial berm, widening the beach. The beach is gradually eroded, with waves and currents redistributing material to the offshore, nearshore bars, and downdrift beaches. The cycle repeats, gradually moving the bluffs landward (Davies 1972). Chute (1946) described bluff erosion along the Cape Cod coast and found that the relative magnitude of bluff erosion was controlled by several factors, including bluff height, vegetation, and composition. Higher bluffs recede at lower rates than low bluffs, due to greater amounts of material yielded for the same recession. Dune ridges and vegetation reduce bluff recession rates, and bluffs composed of till and clay are more resistant to erosion (cohesiveness) than those composed of sand. Davies (1972) summarizes various sources for bluff recession rates along the north shore of Long Island, rates within the study area ranged from $0.3 \mathrm{~m} /$ year $(1 \mathrm{ft} /$ year) to $0.6 \mathrm{~m} /$ year $(2 \mathrm{ft} /$ year) between the $1930 \mathrm{~s}$ and 1960s.

Davies (1972) and Tanski (1981) estimated the rate of supply to the littoral environment as a result of bluff recession. Based on the recession rates at Crane Neck Point and Old Field Point, Davies (1972) estimated bluff sediment supply rates of $15,000 \mathrm{cu} \mathrm{m} /$ year ( 20,000 cu yd/year) and 3,000 cu m/year $(\sim 4,000 \mathrm{cu} \mathrm{yd} /$ year), respectively. The higher rate at Crane Neck is proportional to the greater height $(63 \mathrm{ft})$ and length $(4720 \mathrm{ft})$ of the bluff length compared to Old Field (2360 ft long, $29 \mathrm{ft}$ high). Tanski (1981) estimated bluff supply rates from Mt. Sinai to Orient Point over an 80-year period. On average, he estimated that bluff erosion in this study area supplies $7.5 \times 10^{8} \mathrm{~kg} / \mathrm{year}$; with rates of sand, gravel and silt/clay supply of $5.7 \times 10^{8} \mathrm{~kg} /$ year, $1.3 \times 10^{8} \mathrm{~kg} / \mathrm{year}$, and 
$0.5 \times 10^{8} \mathrm{~kg} /$ year, respectively. Average annual supply rates per kilometer of coastline were estimated at $7.4 \times 10^{6}, 1.7 \times 10^{6}$, and $0.6 \times 10^{6} \mathrm{~kg} / \mathrm{km} /$ year for sand, gravel, and silt and clay, respectively. These rates are variable along the coast. Three areas, from 5 to $10 \mathrm{~km}$ (3.1 to 6.1 miles, Rocky Point), 25 to $40 \mathrm{~km}$ (15.5 to 24.8 miles, Horton Point to Roanoke Point), and 48 to $52 \mathrm{~km}$ (29.8 to 32.3 miles, Mattituck Hills/Oregon Hills area) east of Mt. Sinai Harbor supply unusually large amounts of sediment. Though these areas represent only 28 percent of the study area, they were estimated to supply over 60 percent of the total amount of sediment from bluff erosion.

Tanski (1981) estimated bluff supply rates in kilograms. These values can be converted from mass to volume by:

$$
V=\frac{M}{\rho_{S}(1-a)}
$$

where

$$
\begin{aligned}
M & =\text { mass } \\
\rho_{s} & =\text { sediment density } \\
a & =\text { porosity }
\end{aligned}
$$

A sediment density of $2,650 \mathrm{~kg} / \mathrm{cu} \mathrm{m}$ for quartz sand was specified and porosity set at $0.5^{1}$. Using this relationship, the total average annual volume of sediment supplied from bluff erosion between Mt. Sinai and Orient Point is equivalent to $740,000 \mathrm{cu} y d / y e a r$. Average annual supply of sand, gravel and silt/clay fractions is $563,000 \mathrm{cu} \mathrm{yd} /$ year, $128,000 \mathrm{cu}$ yd/year and 49,000 cu yd/year, respectively. Bluff erosion therefore yields an average annual supply of $12,000 \mathrm{cu}$ yd/year of sand, 2,500 cu yd/year of gravel, and 1,000 cu yd/year of silt and clay per mile of coastline.

Tanski (1981) noted a transition of exposed bluff face to vegetated bluff face between 1930 and 1976, estimating a 33 percent decrease in the surface area of these sections. Aerial photographs showed that much of this change was related to anthropogenic activities. In the long term, this practice will result in a net deficit in the budget, which, in turn, will narrow beaches and elevate shoreline recession rates. The consequences of these practices on the coastal sediment budget may not be immediately apparent.

\section{Sediment sinks}

Although bluff recession supplies large amounts of sediment along the north shore of Long Island, wide beaches are not present. This apparent paradox is attributed to the fact that the beaches along the north shore of Long Island are not acting as permanent sinks for material supplied by the bluffs (Davies 1972;

Tanski 1981; Wise et al. 1978). Observations made by Tanski (1981) from aerial photographs and field inspections showed that material eroded from the bluffs is temporarily deposited on the beach, usually in the form of deposits found at the base of the bluff. Once on the beach, this material is subjected to wave action. Davies (1972) estimated that more than 50 percent of the material supplied by the

\footnotetext{
${ }^{1}$ Personal communication, 28 July 2004, Mr. Jay Tanski, Coastal Processes Specialist, New York Sea Grant Program, Stoney Brook, NY.
} 
bluffs is removed from the beaches by waves. Analysis and comparison of sediment samples from both the beach and bluff at the Old Field Point site showed that beach sediments were lag deposits of the coarser bluff material, consisting mostly coarse sand and gravel. Approximately 20 percent of the bluff material was composed of medium to fine sands, the fraction expected to be transported alongshore in littoral drift (Davies 1972).

Silts and clays are lost to central Long Island Sound, harbors and marshes, or inland to wind transport (Davies 1972; Tanski 1981). Wise et al. (1978) noted the long-term trend of shoreline recession, coupled with the conclusion that north shore harbors were not serving as significant sediment sinks, and they suggested that large amounts of material are moving offshore. They estimated that 84 percent of sediment delivered by bluff erosion must be transported offshore and deposited in the deeper waters of Long Island Sound. Bokuniewicz and Gordon (1980) also noted that erosion of the north shore might be a significant source of sediment supply to Long Island Sound.

Large offshore shoals associated with headland points may be a potential sink for sand-sized bluff sediments. New York District (1969) established comparative transects between bathymetric data collected in 1836-1838, 1883, and 1965. Seaward movement of the 6-, 12-, 18-, 24-ft depth contours was observed at large shoals at Rocky Point Landing, Herod Point, and Roanoke Point. In general, landward movement was typical of the remainder of the coast. The bathymetric imprint of shoals located offshore of Herod and Roanoke Points is shown in Figure 44.

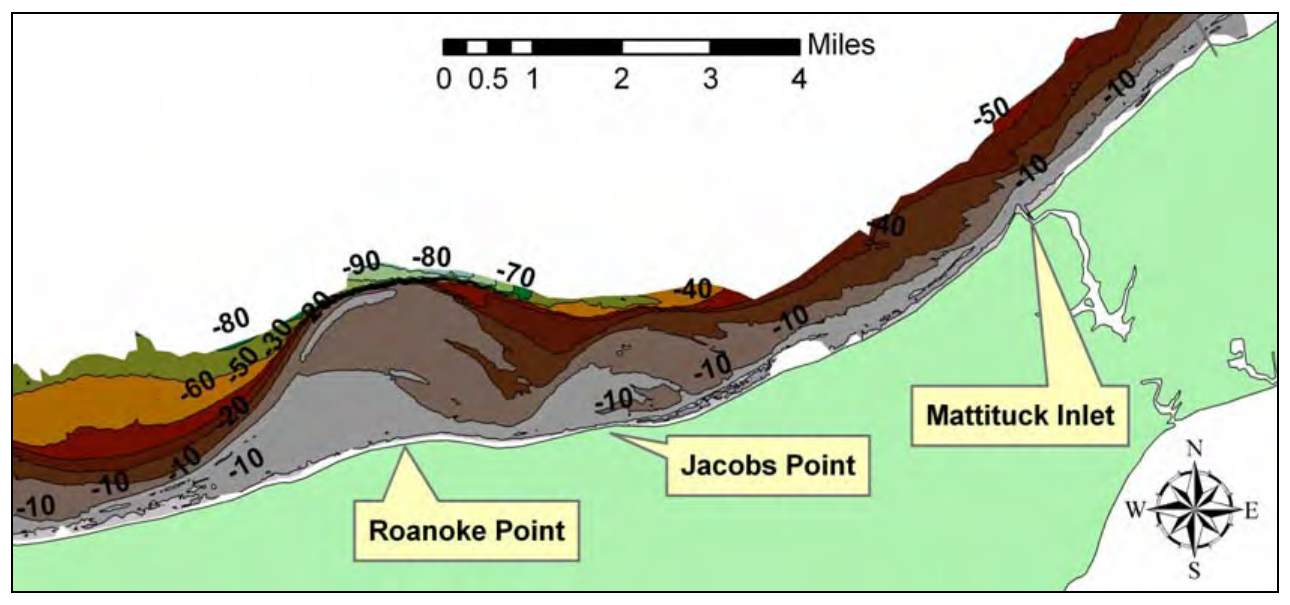

Figure 44. Example of large shoals off Roanoke and Jacobs Point

Another sink of littoral material is impoundment behind shore-perpendicular structures. Of significance to supply of sand into the Mattituck Inlet cell, twin jetties were constructed in the vicinity of Jacobs Hill at Northville. These structures are located approximately 2.5 miles updrift (west) of Mattituck Inlet and extend approximately $500 \mathrm{ft}$ from the shoreline into Long Island Sound. Reduction in sand mining volumes in the early 1970s (Table 6) and results from the shoreline change analysis (1964 to 1969) indicate that these structures reduced the supply of sediment to Mattituck Inlet. The west jetty at Mattituck Inlet has also impounded sand, reducing the supply of material to downdrift 
beaches. The volume of material impounded behind this structure, and impoundment rates are estimated in the following section.

Large volumes of material were removed from the entrance channel and updrift fillet at Mattituck Inlet by sand mining and dredging. The disposal location for material dredged from the inlet channel entrance is not known prior to 1946. After 1946, and omitting the 1961 dredging, material removed from the entrance channel was placed on the beach directly downdrift of the inlet (condition surveys). In total, dredging records indicate removal of approximately $391,000 \mathrm{cu}$ yd (from the channel entrance and vicinity, see note 3 in Table 4), of which 181,000 cu yd was removed prior to 1946 (not including new work and first maintenance dredging, Table 4). It is likely that material was placed offshore or taken to upland disposal sites. The majority of this material appears to have been disposed of offshore, a hypothesis supported by the presence of a large mound or shoal present offshore in the 1927 condition survey, which had eroded by 1969 (see bathymetric change analysis, Figure 27). It appears that the majority of maintenance dredging material was returned to the littoral zone, and therefore, should not be considered a permanent removal from the system.

Commercial sand mining occurred at Mattituck Inlet as early as the 1920s and continued through the 1970s. Sand mining represents a permanent removal of material from the system, and these volumes must be subtracted from the sediment budget. The practice of sand mining from the Federal inlet channel began in the early 1920s and continued through the late 1930s and early 1940s. Federal permits issued during this time period (Table 5) do not record volume of material removed. Most permits were issued for subaerial shoal deposits within the channel entrance to depths between 10 to $20 \mathrm{ft}$ mlw. Total removal of material was estimated at $85,000 \mathrm{cu}$ yd (Chapter 1), but this value has great uncertainty.

Sand mining permitted by the village of Mattituck also occurred along the impoundment fillet west of the inlet. This mining is documented between 1960 and 1975; however, it has been probable that more mining may have taken place (Schubel 1976). The total volume removed from this area between 1960 and 1975 was estimated at $243,000 \mathrm{yd}$. The aerial photographic record suggests that mining of the fillet may have begun sometime between 1947 and 1955. It is possible that between 20,000 and $160,000 \mathrm{cu}$ yd was removed in this time frame, depending on assumptions made. Other mining occurred within the inlet channel, evidenced by removals of material along the channel boundaries and presence of infrastructure indicates that substantial mining was occurring. Removal of material from these areas is unknown; total volume of removed sand and gravel could range from 200,000 to 500,000 cu yd.

In summary, known quantities of sand removed by dredging and mining total $610,000 \mathrm{cu} y d$, and estimates of undocumented volumes removed range from 305,000 to $745,000 \mathrm{cu}$ yd. Total federally permitted mining volume was estimated at 85,000 cu yd. Assuming that material dredged from the navigation channel during maintenance was disposed in the nearshore shoal or on the downdrift beach, it is estimated that the total removal of material by mining and dredging was, at a minimum, 550,000 cu yd (low removal estimates). If all material dredged prior to 1946 was disposed offshore or in upland sites, it is estimated that a total of 1,170,000 cu yd (high removal estimates) of material was removed from the system. 


\section{Longshore transport rates}

Several authors have estimated longshore transport (LST) rates along the north shore of Long Island (Omholt 1974; Tetra Tech, Inc. 1979; Leatherman et al. 1997; Fields et al. 1999), with little agreement found among them. A critical review of these studies is given in this section.

Omholt (1974) attempted to predict longshore transport rates based on rough estimates of yearly average wave conditions in Long Island Sound. Using values of $0.5 \mathrm{ft}, 5 \mathrm{sec}$, and $100 \mathrm{ft}$ for wave height, period, and wavelength, and a shoreline orientation of $20 \mathrm{deg}$, Omholt (1974) estimated the longshore transport rate at 96,000 cu yd/year (gross transport). Tetra Tech, Inc. (1979) predicted a wave climatology for Long Island Sound by hindcasting from wind records for 1974 to 1975 . Based on these data, they estimated the net longshore transport in the area to be $0.9 \times 10^{8} \mathrm{~kg}(86,000 \mathrm{cu}$ yd) to the east per year. Tetra Tech claimed that this value agreed well with estimates of LST rates from sand accumulations behind jetties in the Jamesport area. More recently, Leatherman et al. (1997) estimated the net easterly LST rate at Goldsmith Inlet at 25,000 cu $\mathrm{yd} /$ year given a closure depth of $10 \mathrm{ft}$ below msl and the growth of the impoundment fillet. Fields et al. (1999) estimated the LST rate to the east between 7,500 and 8,000 cu yd/year (+/- 35 percent) based on shoreline advance rates updrift of Goldsmith Inlet and assuming a depth of active transport of $18 \mathrm{ft}$ for the interval 1964 to 1976.

LST rate estimates range from 7,500 to $96,000 \mathrm{cu}$ yd/year. Further, estimates derived from conventional formulas apply to sand, not to gravel or cobble. The lower ranges of rates are supported by sediment impoundment rates at structures, whereas the higher rates are based on empirical predictions using wave data. However, the wave information set driving the sediment-transport models was crude. Omholt (1974) noted that his calculated rate $(96,000 \mathrm{cu} \mathrm{yd} /$ year) appeared to be several times higher than estimates from sand impoundment at structures, and he attributed the discrepancy to longshore transport not meeting full potential. Over prediction of sediment transport by empirical methods is most likely due to inadequate wave information and to the poorly sorted, less mobile, coarse material that comprises north shore beaches and nearshore sediments.

The rate of sediment impoundment behind the west jetty, together with sand mining and dredging volumes, are incorporated in the following to estimate the magnitude of longshore sediment transport at Mattituck Inlet. Estimates of net LST at Goldsmith Inlet range from 8,000 to $25,000 \mathrm{cu}$ yd/year. The LST rate at Mattituck Inlet should fall within these values and is consistent with impoundment at the jetty and channel maintenance dredging records.

\section{Volumetric Change Analysis}

Volumetric change in the study area was calculated from available bathymetric surfaces as well as from shoreline change data. Rates of volumetric change and morphologic evolution of the bathymetric surface at Mattituck Inlet define sediment pathways and transport rates. 


\section{Bathymetric change analysis}

Three bathymetric surfaces were available for comparison; a 1927 New York District condition survey, a 1969 survey conducted by the NOS (1969), and a 2002 survey conducted by OCTI for a CIRP research project (Morgan et al. 2005). The 1969 and 2002 surveys were in digital format; however, the 1927 New York District condition survey was available only in paper chart format. Also, the horizontal reference for the 1927 survey was to a local coordinate system. The paper map was scanned and imported into ESRI ArcMap ${ }^{\circledR}$ for geo-referencing and digitizing of point and contour features. Due to a lack of higher-order control points, the survey map was geo-referenced to a circa 1930 aerial photograph by reference to the jetty locations and other corresponding physical features on the map and photograph. Total rms error in the georeferencing was $65 \mathrm{ft}$; the alignment of mapped hwl lines, jetty positions, and channel location matched well in the across-shore plane (Northing). Offsets on the order of $50 \mathrm{ft}$ were observed in the along-shore plane (Easting). Bathymetric point and contour data were digitized and saved as shapefile feature classes. Each bathymetric point was recorded in the center of the annotated sounding on the paper chart. Contour polylines were digitized along the center of each annotated contour line on the chart at 1:700-ft scale.

The vertical datums of reference for 1927, 1969, and 2002 bathymetric surfaces were mlw, mllw, and NAVD 88, respectively. Because NAVD 88 is the present geodetic datum of reference, the 1927 and 1969 surfaces were adjusted to this datum for comparative analysis. The 1927 survey was referenced to mlw as determined at Ft. Schuyler, NY (datum of reference for survey). Water-level measurements collected during the 1927 survey indicated a difference of $0.3 \mathrm{ft}$ between the Ft. Schuyler and Mattituck mlw tidal datums. The conversion factor published by the NOS for Mattituck Inlet, NY, to the Bridgeport, CT, reference station is 0.76 for low water. The difference between NAVD 88 and mlw at the Bridgeport station was $3.59 \mathrm{ft}$, and applying the conversion factor gives a difference of $2.73 \mathrm{ft}$ for Mattituck Inlet. Sea-level has risen by approximately $0.6 \mathrm{ft}$ (NOS data for Port Jefferson) between 1927 and 2002. Accounting for the $0.3-\mathrm{ft}$ difference between mlw at Mattituck and Ft Schuyler, sea-level rise, and the calculated elevation of mlw at Mattituck Inlet in the current tidal epoch, the total difference between the $1927 \mathrm{mlw}$ and NAVD 88 is $3.63 \mathrm{ft}$. The 1969 surface was referenced to mllw and also required adjustment to NAVD 88 . The NOS published conversion factor defines NAVD 88 at $2.96 \mathrm{ft}$ above mllw for the 1983-2001 epoch at Mattituck Inlet. Sea level has risen by approximately $0.26 \mathrm{ft}$ (NOS, Port Jefferson) between 1969 and 2002. These two considerations yield a difference of $3.22 \mathrm{ft}$ between $1969 \mathrm{mllw}$ and NAVD 88.

The three bathymetric surfaces were compared in ESRI ArcMap ${ }^{\circledR}$ using the spatial and 3-D analyst extensions. Triangulated irregular networks (TIN) were generated for each survey to the spatial extent of the 1927 survey (smallest). The volume of each surface was calculated above the $-30 \mathrm{ft}$ NAVD 88 contour. TIN surfaces were converted to raster grid surfaces to calculate depth changes between surveys.

A net gain of 155,000 cu yd was calculated between 1927 and 1969, giving an accretion rate within the defined accretion zone of approximately $4,000 \mathrm{cu} \mathrm{yd} /$ year. Depth changes during this interval are shown in Figure 45. Updrift of the inlet, morphologic change included movement of the bar complex 
offshore, and deposition in the nearshore impoundment area. Downdrift, a large area of erosion is observed together with deposition further offshore. Crosssections of this downdrift area show steep side slopes and a mound appearance, suggesting that it was a disposal area for dredged material.

Net accretion within the total compared area was calculated for the 1969 to 2002 interval, resulting in a gain 188,000 cu yd of material, a net rate of approximately 6,000 cu yd/year. Depth changes are shown in Figure 46. For this interval, deposition was dominant in the nearshore impoundment area updrift of the inlet and in a shoal complex downdrift of the inlet. This complex appears attached to the impoundment area updrift of the inlet, suggesting bypassing of, at least, finer sediment along this pathway. Other changes include apparent onshore movement of the nearshore bar updrift of the inlet.

Depth change between the 1927 and 2002 surface is shown in Figure 47. Net change over the entire interval shows large amounts of deposition in the nearshore updrift impoundment area, and in the nearshore bar complex. It appears that a bypassing bar has grown from the impoundment area and has become established across the throat of the inlet, and extending around the tip of the east jetty. This feature was isolated from the impoundment area, and volume change was calculated within the extent of the shoal. The feature gained 16,000 cu yd between 1927 and 1969, and 21,000 cu yd between 1969 and 2002. Corresponding accretion rates were low, at approximately $400 \mathrm{cu}$ yd/year and $600 \mathrm{cu}$ yd/year, respectively.

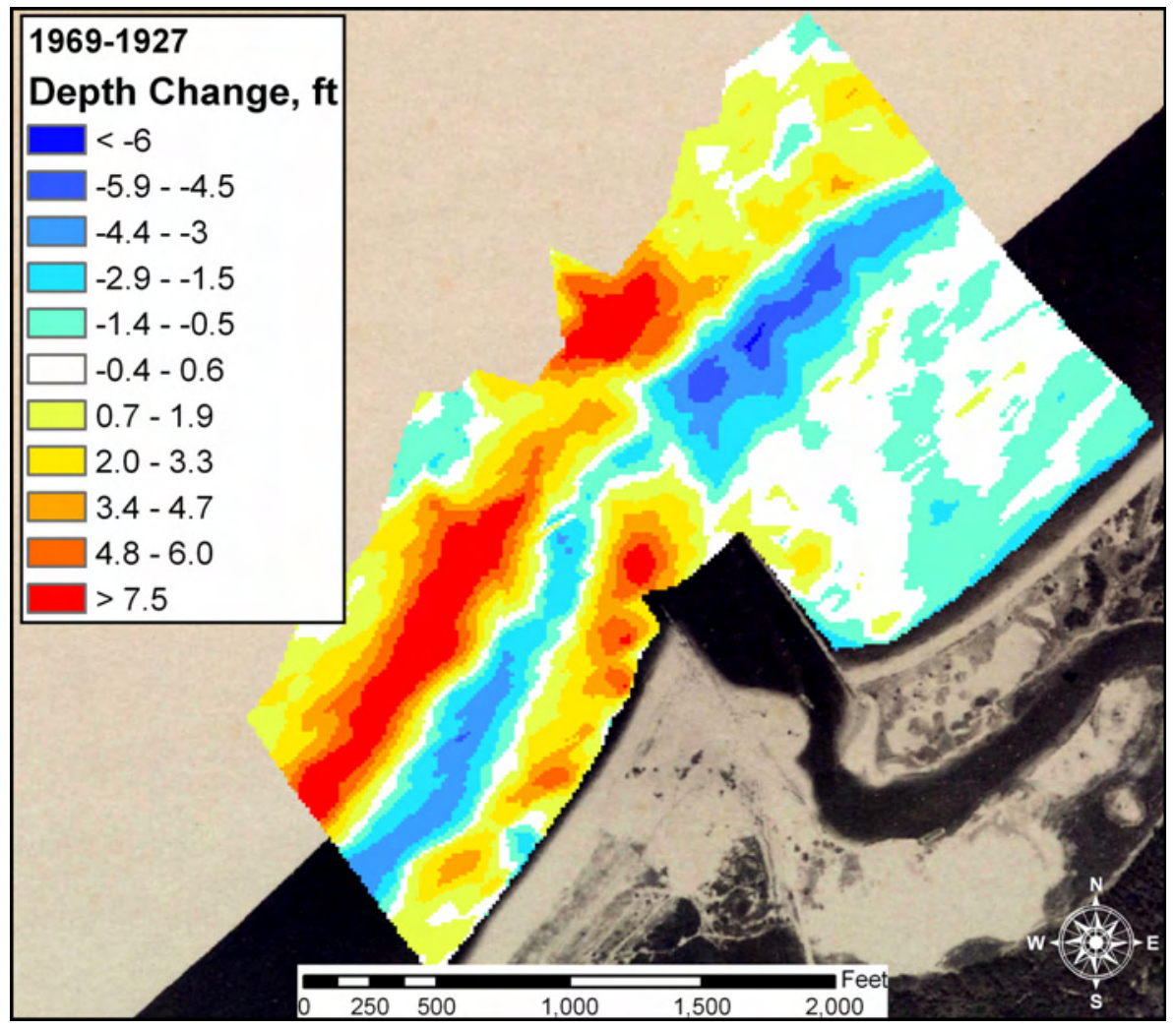

Figure 45. Depth change between 1927 and 1969 (year 1927 photograph) 


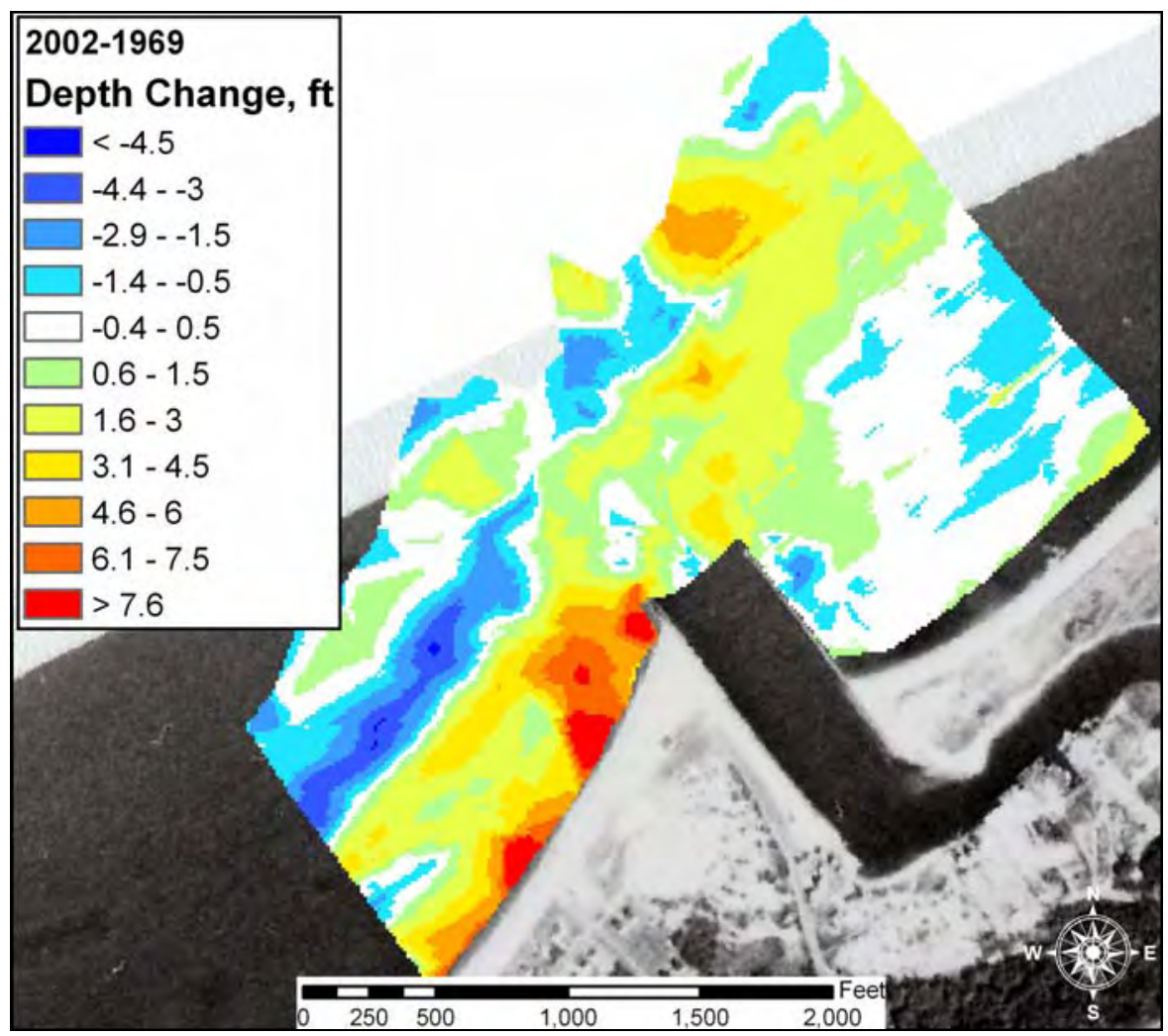

Figure 46. Depth change between 1969 and 2002 (year 1969 photograph)

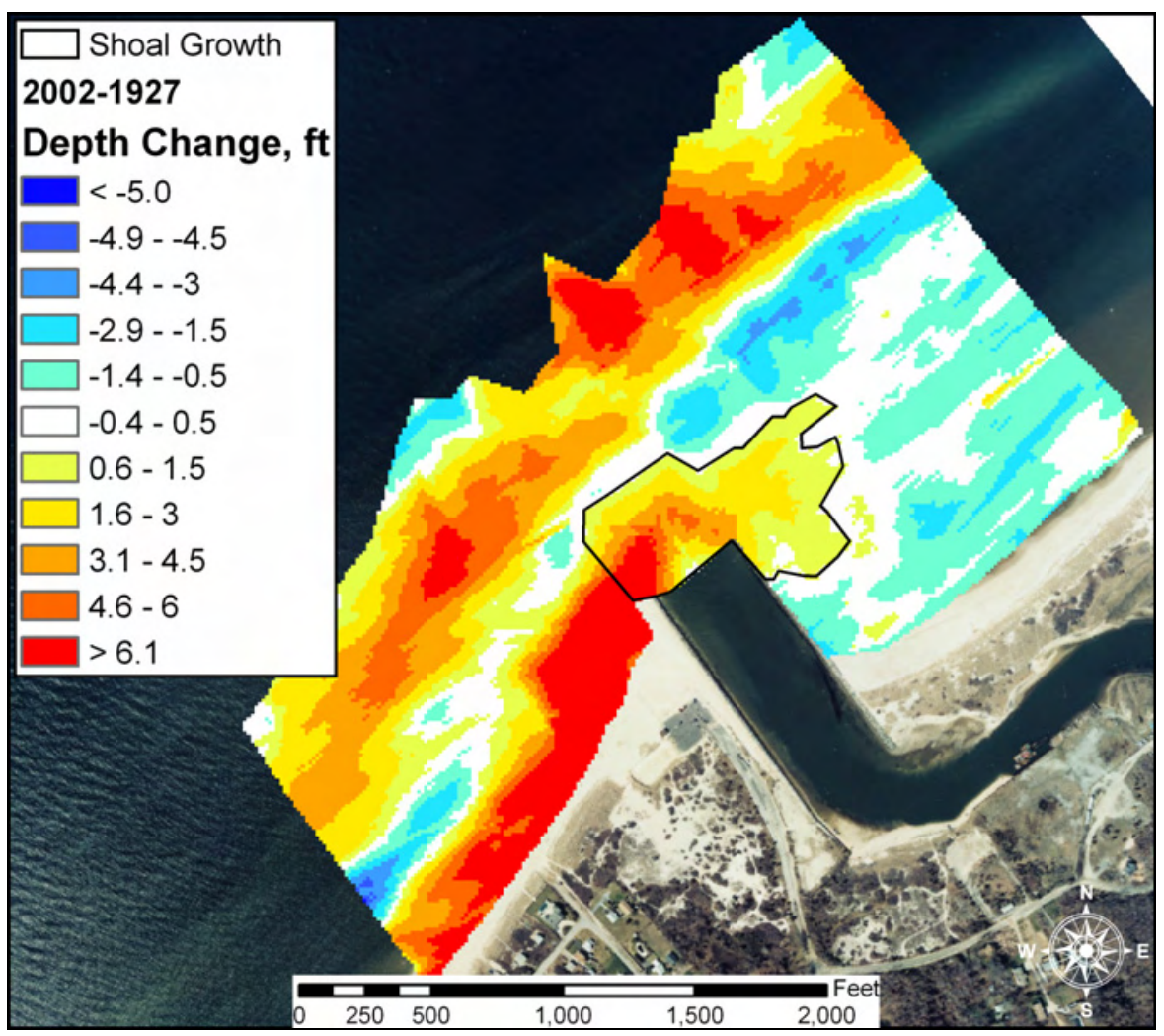

Figure 47. Depth change between 1927 and 2002 (year 2001 photograph) 
Bathymetric surfaces from 1969 and 2002 had a greater spatial extent than the 1927 survey. Therefore, raster grid surfaces and TINs were recalculated to the extent of the 2002 survey to investigate bathymetric change over a broader area. Erosion was the dominant process between the two surfaces. Volume change was calculated as a loss of 268,000 cu yd, yielding an erosion rate of $8,000 \mathrm{cu} \mathrm{yd} /$ year over the entire area. Change in depth between the two surveys is shown in Figure 48. Accretion was limited to areas previously discussed; the impoundment area updrift of the inlet, the nearshore bar, and the apparent bypassing bar. This bypassing complex, including the feature around the tip of the east jetty, appears to have developed as an extension of the updrift impoundment area. Isolation of the entire shoaling area from the surface (Figure 49) allowed calculation of volume gains at 293,000 cu yd, an accretion rate of approximately $9,000 \mathrm{cu}$ yd/year.

The shoal features were isolated to estimate sediment accretion unassociated with the shoreline (Figure 49). Volume gains in this area were calculated at $118,000 \mathrm{cu} y d$, giving an accretion rate of approximately $3,000 \mathrm{cu}$ yd/year. Accretion within the impoundment fillet was calculated by subtracting gains in the shoaling polygon from the bypass bar polygon. Total volume gain in the impoundment fillet was 175,000 cu yd, giving an accretion rate of

$5,300 \mathrm{cu} \mathrm{yd} /$ year. This volume change and change rate represent only the growth of the subaqueous surface.

Morphologic evolution between the 1969 and 2002 suggests that sediment bypassing pathways are being established across the entrance of Mattituck Inlet. These pathways will continue to become more efficient and should contribute toward reducing shoreline recession rates downdrift of Mattituck Inlet. Although it is apparent that the offshore shoal growth is a result of sediment transport along these pathways, it is possible that some portion of the 3,000 cu yd/year of could originate from other sources. Material that is transported westward and deflected off the east jetty, as well as removed from the east beach during storms, may be deposited on the shoal complex. Inferred sediment bypassing pathways based on morphologic change are illustrated in Figure 50, and their probable existence is confirmed by hydrodynamic and sediment transport modeling described in Chapter 3. Accretion has occurred where the colored surface (2002) overlays the grey-scale surface (1969). Arrows indicate interpreted sediment bypassing transport pathways across the inlet. Vertical exaggeration is 20:1. 


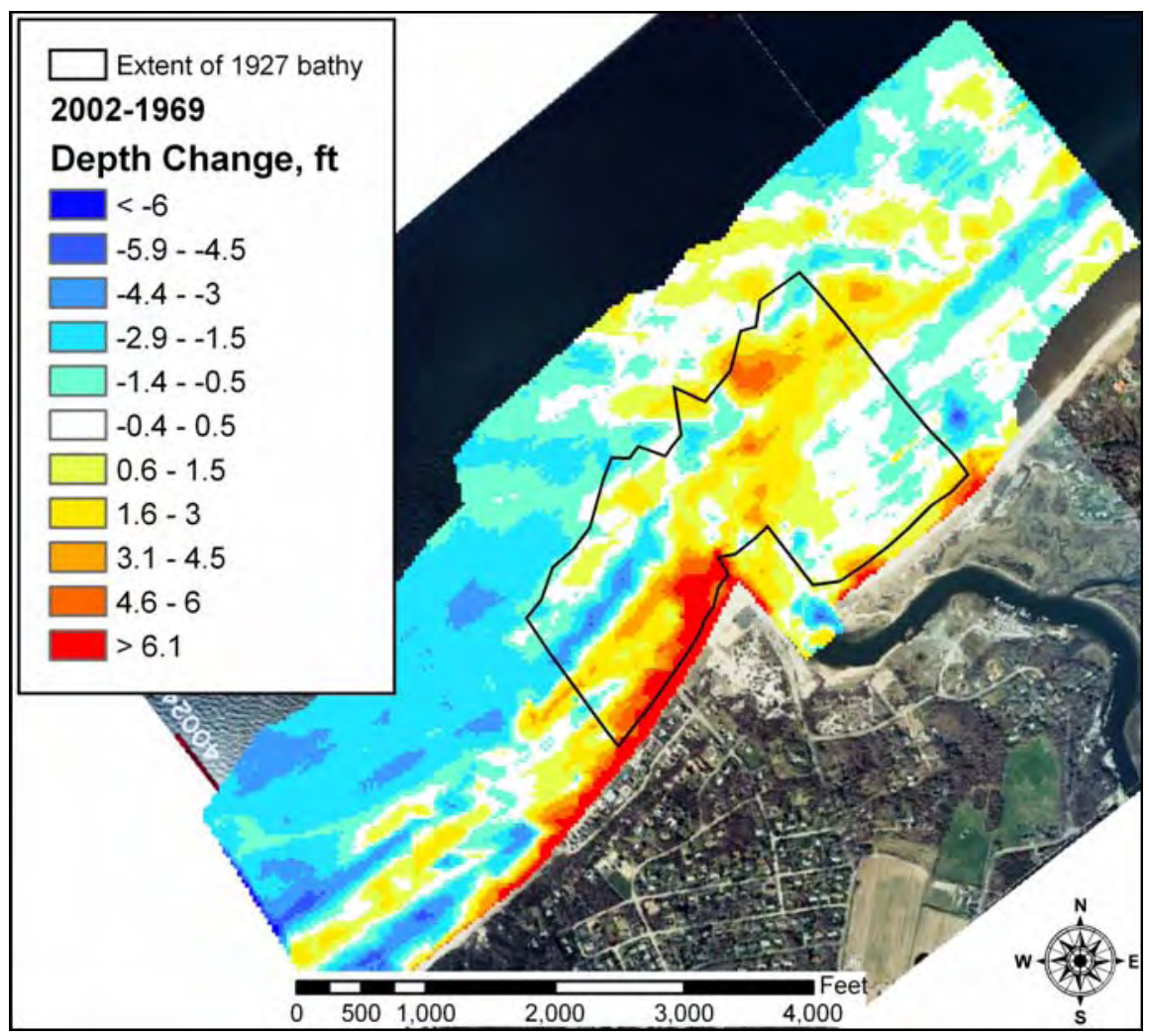

Figure 48. Depth changes between 1969 and 2002

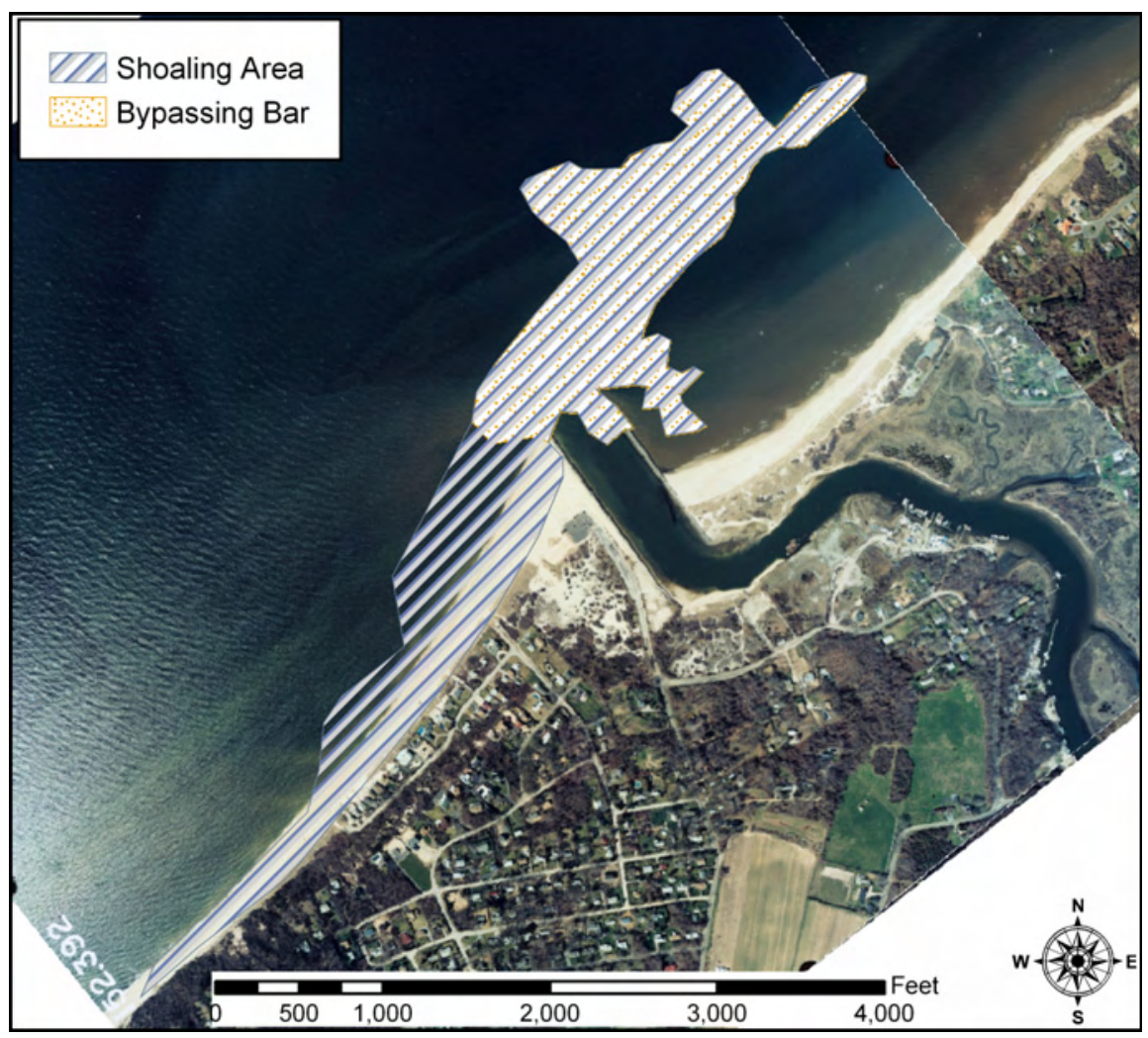

Figure 49. Delineation of shoaling area and bypassing bar 


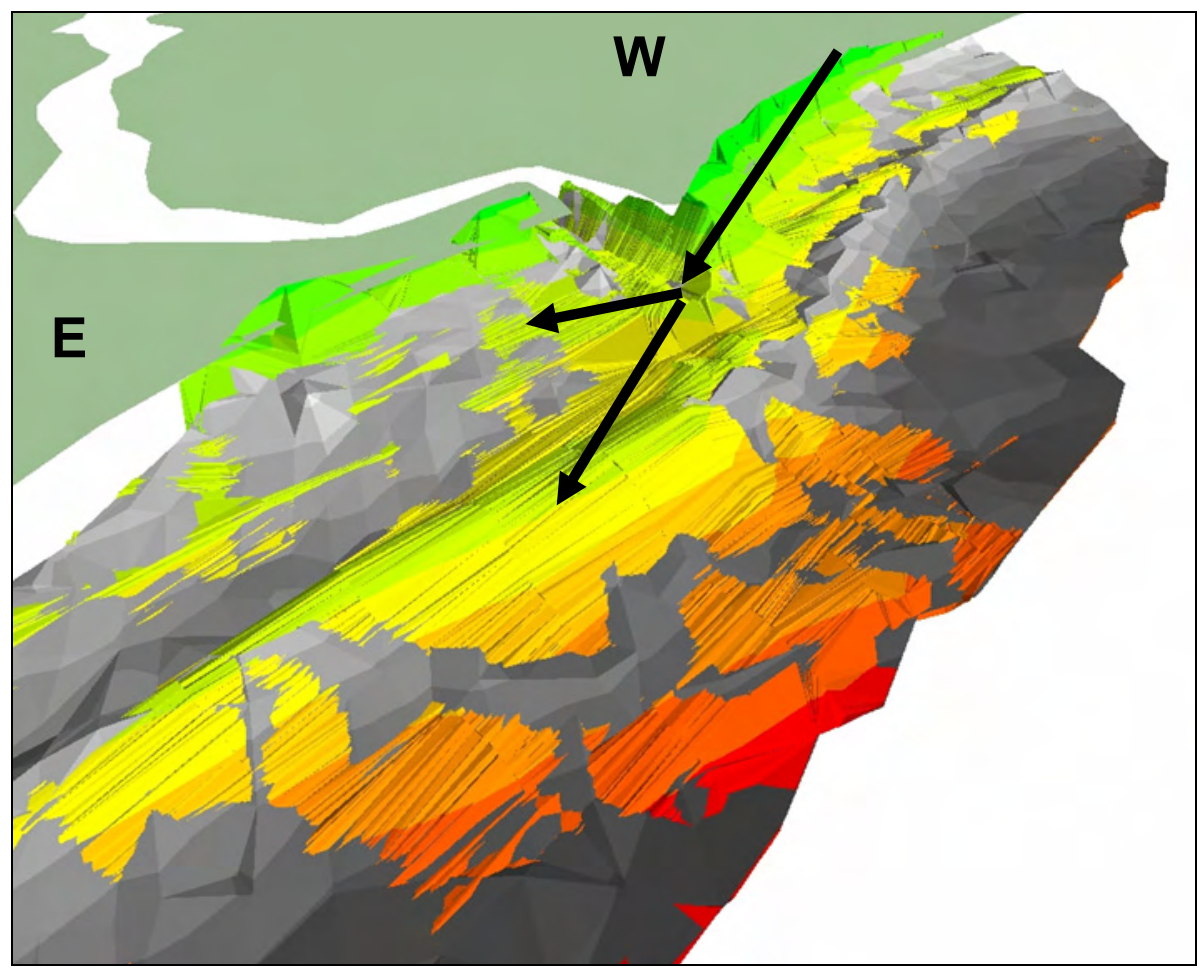

Figure 50. 3-D view of bathymetric surface change between the 1969 (greyscale) and 2002 (color) and interpreted sediment bypassing pathways

\section{Shoreline change data}

Volumetric change rates can be derived from shoreline change data assuming uniform recession of the beach profile over the depth of active transport (Kraus et al. 1999). The depth of active transport $D_{A}$ represents the beach profile from the berm crest (limit of wave uprush under average conditions) to the depth of closure. Volume change and change rates determined from this calculation represent only this portion of the profile, and they do not account for erosion of back-lying dunes and bluffs. The depth of active transport is defined as the zone that littoral forces regularly transport sediments on the cross-shore profile:

$$
D_{A}=B+D_{C}
$$

where berm elevation $B$ is the upper limit, and the depth of closure $D_{C}$ is the lower limit.

Surveyed beach profiles within the Mattituck littoral cell were reviewed to determine depth of closure and berm height. Profiles from a 1998 survey provided the most comprehensive coverage of the study area. Berm heights

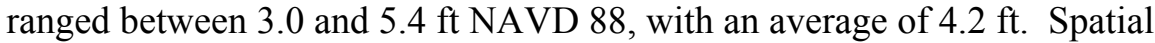
coverage for the 2002 profile survey was limited; berm heights from these profiles were similar to the 1998 profiles. Values ranged between 3.0 and $5.8 \mathrm{ft}$ NAVD 88, with an average of $4.4 \mathrm{ft}$. The higher berm elevations represent sediment reworking during storms, and lower values are representative of calmer conditions. The average value lies between the minima and maxima, and 
provides a representative value for both processes. Therefore, a berm elevation of $4.3 \mathrm{ft}$ was assigned (average of all profiles).

Depth of closure was evaluated as the depth at which offshore profiles at a particular station over time converged (or closed). This depth is commonly assumed to be the most landward depth seaward of which there is no significant exchange of sediment between the beach and offshore over the time interval of interest (Kraus et al. 1999). The depth of closure was evaluated at comparable transects for the period 1998-2001. For the 13 transects, depth of closure ranged from 7.5 to $10.9 \mathrm{ft}$, referenced to NAVD 88 , with average and median values of 8.8 and $8.3 \mathrm{ft}$. Profiles updrift of the inlet show movement of barforms, making the depth of closure difficult to evaluate. The greater closure depths $(>10 \mathrm{ft})$ occurred between barforms and may not be reliable. In addition, these closure depths are representative of a short interval ( 3 years), whereas the project time frame is decadal.

To evaluate depth of closure over a longer time frame, profiles (sta PL-56 and sta PL-57) from the 1969 Beach Erosion Control and Interim Hurricane Study (New York District 1969) were digitized and converted to NAVD 88. Sta PL-56 is located 1,200 ft west of the channel entrance, and sta PL-57 is located 2,000 ft east of the channel entrance. Closure was again difficult to establish updrift of the inlet due to movement of barforms. Downdrift, closure was well defined at $9.3 \mathrm{ft}$ NAVD 88 between profiles from sta C5 and 1969 profile sta PL-57 (Figure 51). This value was taken as the representative depth of closure for this study. Given a berm elevation of $4.3 \mathrm{ft}$, and depth of closure of $9.3 \mathrm{ft}$ NAVD 88 , the depth of active transport is $13.6 \mathrm{ft}$, rounded to $14 \mathrm{ft}$ for this analysis.

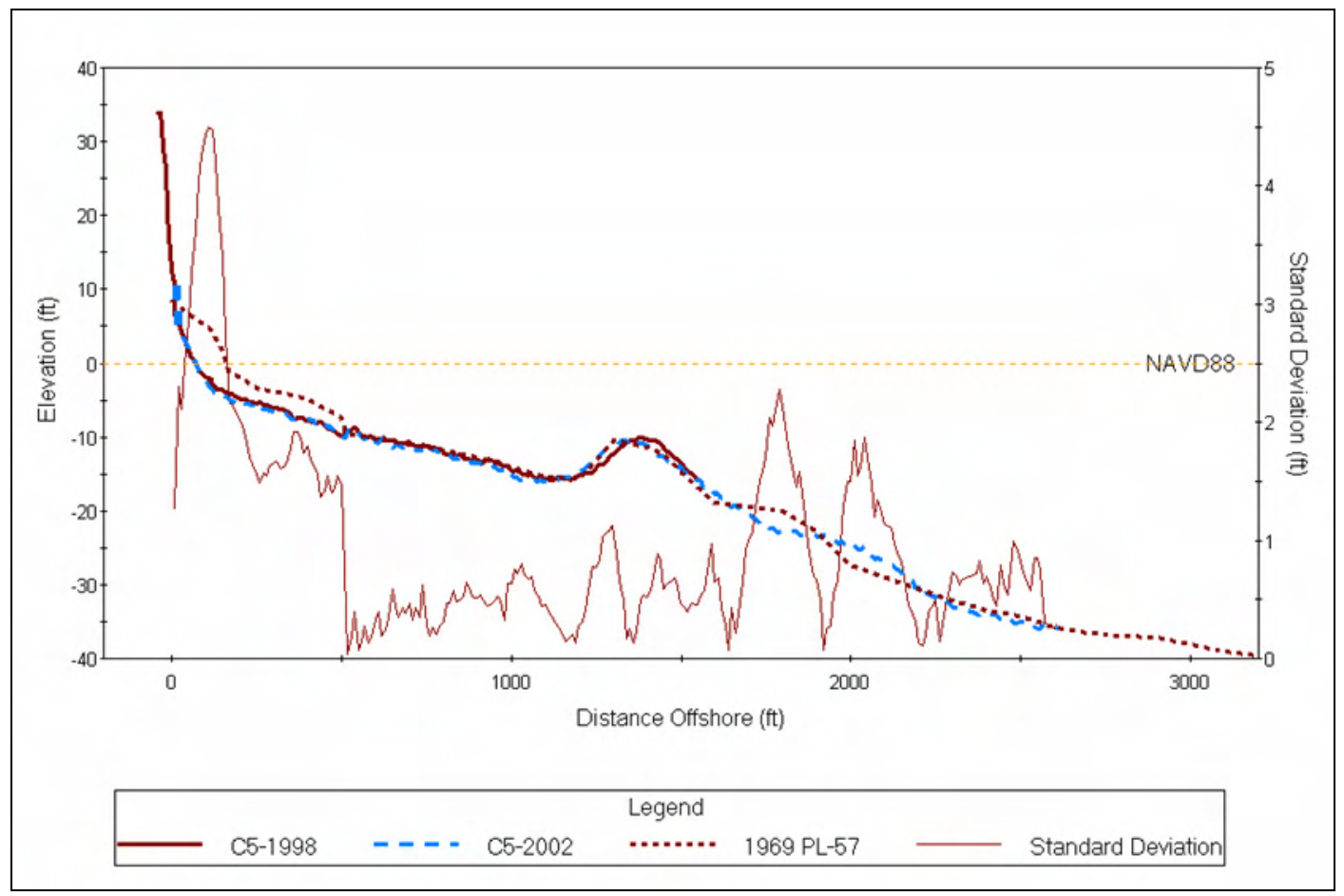

Figure 51. Comparison of 1969, 1998, and 2001 profiles at sta C5, Mattituck Inlet 
Volumetric change estimates were calculated within each shoreline change sub-cell (50 ft). The regional and local budgets contain 3,348 (164,721 ft) and $273(13,431 \mathrm{ft})$ sub-cells, respectively. Cell width was constant throughout the study area, except where cells bordered on inlets. The volume change calculated for each cell represents alongshore extrapolation of the $D_{A}$ estimate from the transect location to the midpoint between the reference transect and adjacent transects (Figure 52). Volumetric change was calculated from shoreline change rates using the equilibrium beach profile model (Kraus et al. 1999),

$$
\Delta V=\Delta y \Delta x D_{A}
$$

where $\Delta y=$ shoreline change, and $\Delta x=$ alongshore cell length. The depth of active transport was $14 \mathrm{ft}$. For example, a 1-ft advance or recession of the shoreline would result in a volume change $0.5 \mathrm{cu}$ yd for a $1-\mathrm{ft}$ length of coast. Over the length of coast represented by the shoreline change sub-cell (49 ft), a 1 -ft advance or recession would result in a volume change of $26 \mathrm{cu}$ yd. Results of volume change calculations are discussed in the local and regional sediment budgets (following sections).

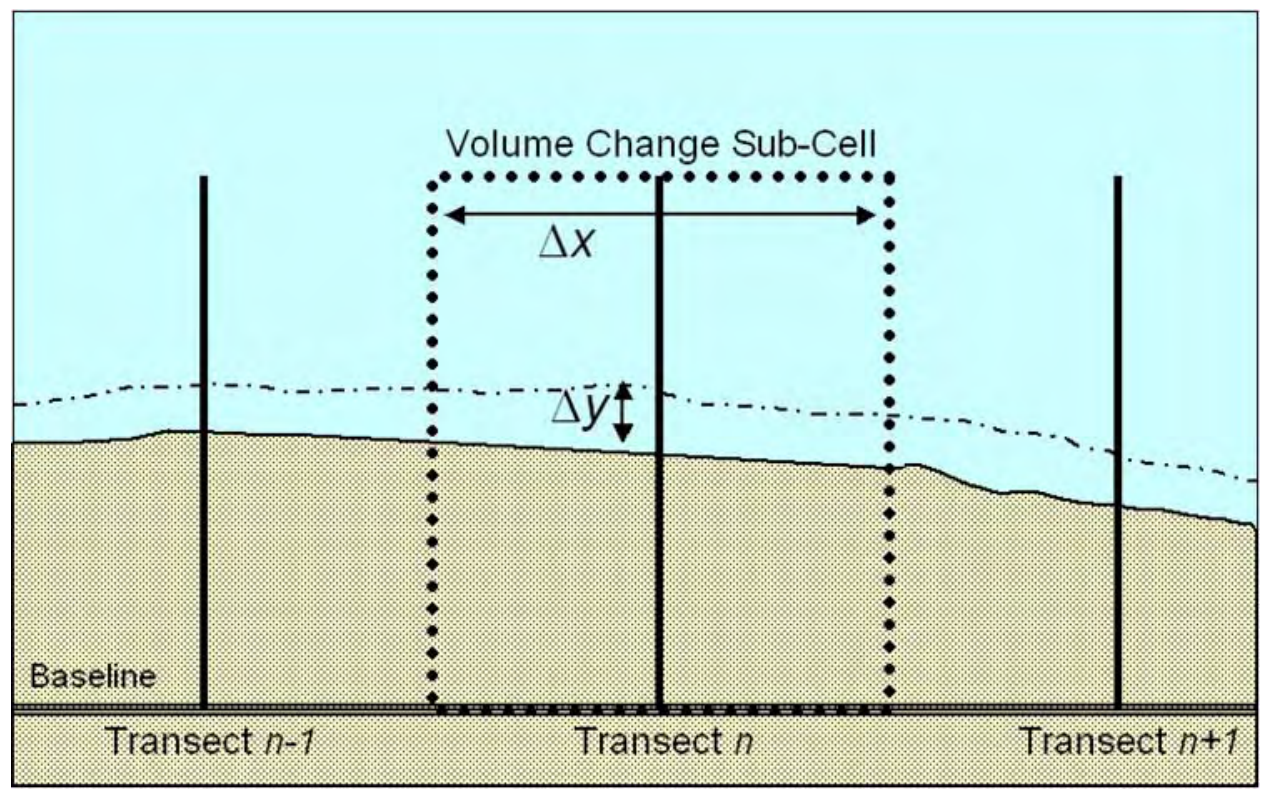

Figure 52. Illustration of volume change sub-cell

\section{Impoundment rates}

In this section, impoundment rates updrift of the west jetty are estimated by both shoreline change and by measurement of fillet area. The two methods are similar; however, the fillet area analysis allows inclusion of additional dates for which image quality was inadequate for accurate shoreline extraction. The accretion fillet updrift of Mattituck Inlet represents a local sink for littoral material. Estimates of the local longshore transport rate may be derived from the rate of sand impoundment updrift of a structure, until it reaches capacity. Once 
the impoundment reservoir nears or reaches capacity, material will begin to bypass the structure, moving into either the navigation channel or ebb shoal.

The area of the impoundment fillet was measured from available rectified aerial photography. This was accomplished within the GIS environment by digitizing the extent of the impoundment fillet using polygon layers. A baseline polygon was established along this section, with the landward boundary along the average orientation of the coast (about $322 \mathrm{deg}$ ) and the seaward boundary the location of the 1885 NOS shoreline. The eastern boundary was set at the location of the west jetty, and the western boundary was established from the extent of the accretion area as identified by shoreline change analysis. The varying resolution of available imagery prevented the use of the hwl shoreline definition; therefore, the land-water interface was employed. It is assumed that all aerial photographs were taken at low tide or lower water. To determine accretion and erosion of the fillet, the area of the baseline polygon was subtracted from polygon area for each date. Volume was determined through multiplying the area of the polygon by depth of active transport ( $14 \mathrm{ft})$. Error was estimated by multiplying the rms error of the image rectification by the depth of active transport and the length of the impoundment compartment. Possible lack of tide control throughout the images could introduce additional error into area measurements. This error was estimated at 78,000 cu yd. Potential error of each estimate was calculated as the product of the image rectification error, the depth of active transport, and the length of the compartment. Results are listed in Table 13.

\begin{tabular}{|c|c|c|c|c|c|}
\hline \multicolumn{6}{|c|}{$\begin{array}{l}\text { Table } 13 \\
\text { Impoundment Fillet Growth Estimated by Fillet Area }\end{array}$} \\
\hline Date & Area, sq ft & $\begin{array}{l}\text { Volume, } \\
\text { cu yd }\end{array}$ & $\begin{array}{l}\text { Volume change from } \\
\text { previous fillet, } \\
\text { cu yd }\end{array}$ & $\begin{array}{l}\text { Rate of change, } \\
\text { cu yd/year }\end{array}$ & $\begin{array}{l}\text { Potential Error, } \\
\text { cu yd }\end{array}$ \\
\hline 1930 & 608,200 & 315,400 & 315,400 & 7,000 & 111,300 \\
\hline 1941 & 857,600 & 444,700 & 129,300 & 11,800 & unknown \\
\hline 1947 & 801,400 & 415,500 & $-29,100$ & $-4,900$ & 21,100 \\
\hline 1955 & 766,000 & 397,200 & $-18,400$ & $-2,300$ & 20,500 \\
\hline 1961 & 935,000 & 484,800 & 87,600 & 14,600 & 17,100 \\
\hline 1969 & 679,600 & 352,400 & $-132,400$ & $-16,600$ & 7,700 \\
\hline 1976 & 657,700 & 341,000 & $-11,400$ & $-1,600$ & 3,800 \\
\hline 1994 & 795,300 & 412,400 & 71,400 & 4,000 & 18,000 \\
\hline 1999 & 801,700 & 415,700 & 3,300 & 700 & 59,500 \\
\hline 2001 & $1,001,000$ & 519,000 & 103,300 & 14,800 & 16,200 \\
\hline 2004 & $1,094,700$ & 567,600 & 48,600 & 16,200 & 19,800 \\
\hline
\end{tabular}

From the 1885 shoreline to the circa 1930 photograph, losses appear in the far western extent of the impoundment area, quickly turning to gains that increase steadily towards the jetty. Between 1930 and 1941, increases in area from uniform shoreline advance are apparent throughout the impoundment area. Area losses from 1941 to 1947 are a result of shoreline recession in the western extent of the impoundment fillet. The extent of the accretion fillet remained approximately the same from 1947 to 1955 . At this point, the 1955 fillet area 
directly adjacent to the jetty reached the seawardmost extent prior to 2004 . Between 1955 and 1961, uniform advance of the shoreline was observed within the impoundment area, except for an area of removal beginning about $660 \mathrm{ft}$ west of the jetty. This removal is evidence of documented mining of the fillet between 1960 and 1975 (Schubel 1976). Losses of impoundment area continue through the 1976 photograph. These losses are also attributed to mining of the fillet. From 1976 through 1994, the area increased, with the majority of the area gained in the western portion of the fillet. Fillet area remained approximately the same between 1994 and 1999, followed by large, uniform gains in 2001 and 2004. Fillet area for 1885, 1930, 1955, 1976, and 2004 is shown in Figure 53.

Rates of sediment accumulation updrift of the west jetty were variable. This variability can be attributed to changes in the longshore transport rate through time, storms, sand mining, and error in interpreting the aerial photography. The rate of impoundment varies from a maximum of $16,200 \mathrm{cu} y d / y e a r$ between 2001 and 2004, to a minimum of $700 \mathrm{cu}$ yd/year from 1994 to 1999 . Total volume gained in the impoundment since 1885 is $567,600 \mathrm{cu}$ yd (17 percent potential error, $97,800 \mathrm{cu} \mathrm{yd}$ ), or 4,600 cu yd/year.

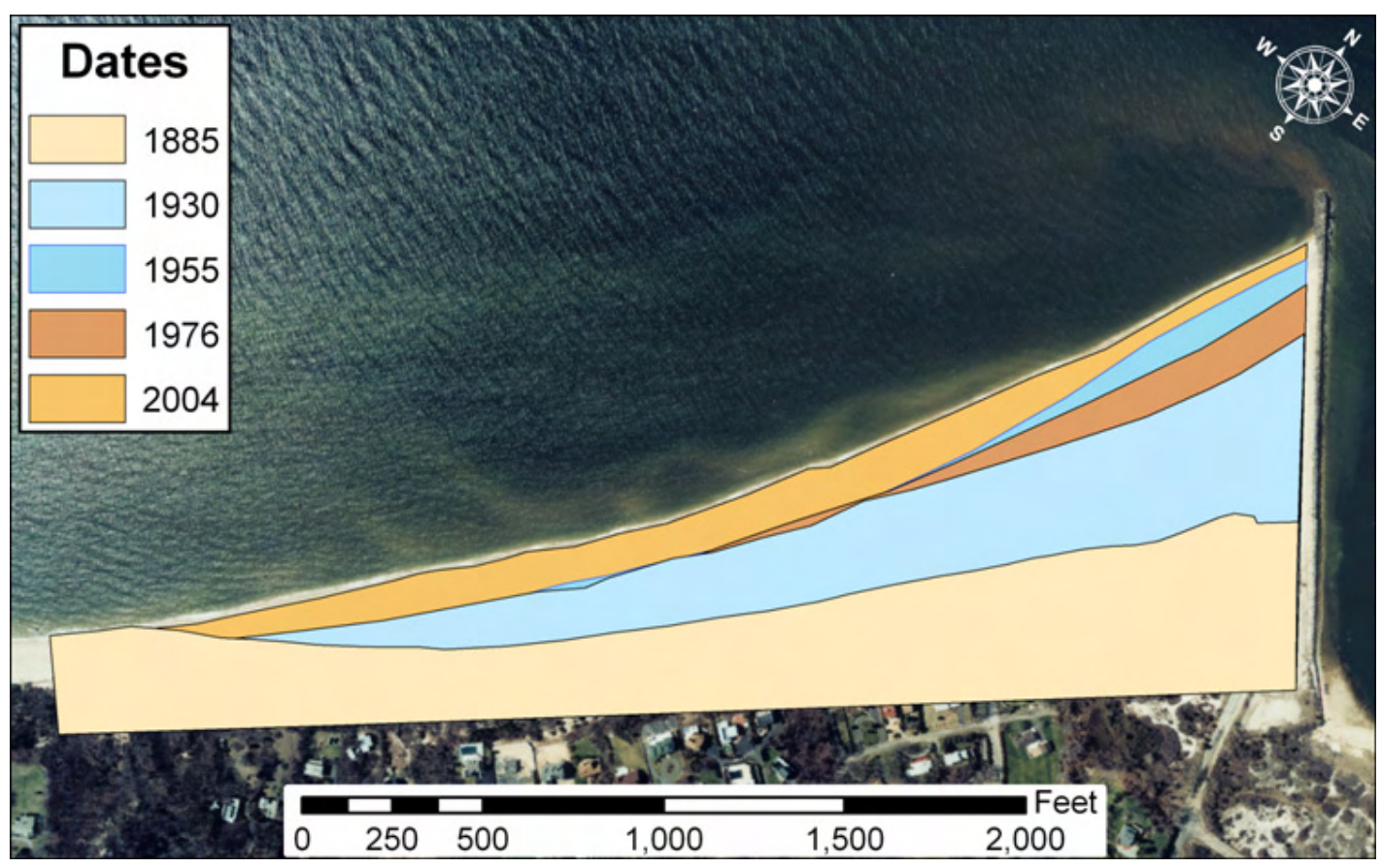

Figure 53. Impoundment updrift of Mattituck Inlet, year 2004 photograph

Impoundment volume was also evaluated by analysis of shoreline position change. Total volume gain or loss within the impoundment area was estimated by multiplying rates and the depth of active transport. Error was estimated by multiplying the total rms error of shorelines from each interval, and then multiplying by the depth of active transport and the length of the impoundment compartment. Results are shown below in Table 14. Cumulative volume represents the total volume gained through each shoreline change interval. This cumulative volume can be compared to the volume determined from the 
end-member analysis in the last row of Table 14. Potential error was calculated as the product of the rms shoreline change rate error, time interval, the depth of active transport, and the length of the compartment.

\begin{tabular}{|c|c|c|c|c|}
\hline \multicolumn{5}{|c|}{$\begin{array}{l}\text { Table } 14 \\
\text { Impoundment Fillet Growth Estimated by Shoreline Change Rate }\end{array}$} \\
\hline Interval & $\begin{array}{l}\text { Cumulative Volume, } \\
\text { cu yd }\end{array}$ & $\begin{array}{l}\text { Volume change, } \\
\text { cu yd }\end{array}$ & $\begin{array}{l}\text { Rate of change, } \\
\text { cu yd/year }\end{array}$ & $\begin{array}{l}\text { Potential Error, } \\
\text { cu yd }\end{array}$ \\
\hline $1885-1930$ & 267,100 & 267,100 & 5,936 & 170,300 \\
\hline 1930-1955 & 397,700 & 130,600 & 5,148 & 144,000 \\
\hline $1955-1964$ & 287,400 & $-110,300$ & $-12,400$ & 51,300 \\
\hline 1964-1969 & 269,900 & $-17,500$ & $-3,500$ & 51,400 \\
\hline 1969-1976 & 260,800 & $-9,100$ & $-1,300$ & 51,300 \\
\hline $1976-1980$ & 219,500 & $-41,300$ & $-10,400$ & 55,500 \\
\hline 1980-1993 & 318,600 & 99,100 & 7,600 & 51,300 \\
\hline 1993-1998 & 347,200 & 28,600 & 5,700 & 51,400 \\
\hline 1998-2004 & 408,500 & 61,300 & 10,200 & 100,200 \\
\hline $1885-2004^{1}$ & $\mathrm{n} / \mathrm{a}$ & 392,700 & 3,300 & 86,400 \\
\hline
\end{tabular}

Total impounded volume as estimated by shoreline change and the depth of active transport was between $392,700 \mathrm{cu}$ yd (end members) and 408,500 cu yd (sum of intervals). The difference $(15,800 \mathrm{cu} \mathrm{yd})$ in the two values is small (about 3 percent) and is attributed to improved temporal resolution of the interval data.

In general, results of the area and shoreline change analyses are similar, though the area analysis produced a higher impoundment volume. The difference between the polygonal area analysis and the cumulative shoreline change rate analysis was $159,100 \mathrm{cu}$ yd, approximately 28 percent of the high value. The area analysis had better resolution through time, but greater error. Difference in the total volume gain is attributed to the dates of available data, the shoreline definition between the two methods, and sand mining from the accretion fillet. The amount determined from the shoreline analysis has lower potential error; therefore, it is considered the better estimate.

Documented sand mining from the impoundment fillet removed $243,000 \mathrm{cu}$ yd of material (Table 6). To provide a more accurate estimate of total impoundment, volume losses calculated by the shoreline change analysis were separated from known mining of the impoundment fillet. The difference $(64,800 \mathrm{cu} y d)$ was then subtracted from the total impoundment volume for a value of $343,700 \mathrm{cu}$ yd. Addition of known mining volume back into impounded volume resulted in a total impoundment volume of 586,700 cu yd. Additional, undocumented mining of the impoundment fillet could have occurred prior to 1960. It was estimated that undocumented mining may have removed 20,000 to $160,000 \mathrm{cu}$ yd of material. If the higher value of undocumented mining were assumed, the total impoundment volume could possibly reach $746,700 \mathrm{cu} \mathrm{yd}$. This value should be considered a maximum estimate of total impoundment. 
In summary, the best estimate of impoundment updrift of the west jetty at Mattituck Inlet is $586,700 \mathrm{cu}$ yd, with a maximum estimate of $746,700 \mathrm{cu}$ yd, for the interval 1885 to 2004 . During that interval, and particularly after the fillet shoreline approached the seaward end of the west jetty, some indeterminate volume of sediment entered the inlet, was diverted offshore, and also bypassed the jetties.

\section{Shoaling rates in Mattituck Inlet}

Rates of sediment shoaling in the Mattituck Inlet navigation channel were determined from dredging records available from the New York District.

Shoaling rates for each dredging interval are listed in Table 15. It was expected that shoaling rates would decrease after the 1938 extension of the west jetty; however, this trend is not apparent from the records. It is possible that pre-1938 dredging volumes are artificially lower due to federally permitted commercial sand mining in the inlet channel. It was estimated that sand and gravel mining from the inlet entrance channel totaled approximately 85,000 cu yd between 1925 and 1943 (Chapter 1). This volume would increase shoaling rates in this time period by an additional 4,700 $\mathrm{cu}$ yd/year. Since 1965, shoaling in the navigation channel has been moderate at Mattituck Inlet, with shoaling rates averaging 1,000 to $2,000 \mathrm{cu}$ yd/year in the modern (post-1980) era.

\begin{tabular}{|l|l|l||}
\hline \multicolumn{2}{|l||}{$\begin{array}{l}\text { Table 15 } \\
\text { Shoaling Rates in Mattituck Inlet }\end{array}$} \\
\hline \hline Dates & Interval, year & Shoaling Rate, cu yd/year \\
\hline \hline $1914-1921$ & 7.0 & 2,000 \\
\hline $1921-1923$ & 1.8 & 27,000 \\
\hline $1923-1927$ & 4.1 & 12,000 \\
\hline $1927-1936$ & 8.5 & 6,000 \\
\hline $1936-1938$ & 2.3 & 8,000 \\
\hline $1938-1946$ & 8.3 & 7,000 \\
\hline $1946-1950$ & 4.0 & 6,000 \\
\hline $1950-1955$ & 4.8 & 7,000 \\
\hline $1955-1961$ & 6.1 & 7,000 \\
\hline $1961-19651$ & 4.0 & 1,500 \\
\hline $1965-1980$ & 14.4 & 2,000 \\
\hline $1980-1990$ & 10.4 & 1,000 \\
\hline $1990-2004$ & 13.6 & 1,000 \\
\hline \hline 1 Material removed from section of channel near inlet (see Table 4). \\
\hline \hline
\end{tabular}

\section{Volume losses in area of inlet influence}

Volume estimates of sediment losses were calculated within the identified area of downdrift shoreline recession. The magnitude of erosion attributable to the inlet was determined by the residual recession rate, the length of the compartment, and the time period of interest. Although rates were determined for the interval 1885 to 2004 , the Federal navigation project was not completed 
until 1906. This gives a 98-year period of interest. Volumes losses are tabulated in Table 16. Overall, 147,000 cu yd was lost in the primary erosion area, and $88,000 \mathrm{cu}$ yd was lost in the secondary erosion area for a total of $235,000 \mathrm{cu}$ yd.

\begin{tabular}{|l|c|c||}
\hline \hline \multicolumn{3}{|l||}{$\begin{array}{l}\text { Table 16 } \\
\text { Volume Losses Attributable to Mattituck Inlet }\end{array}$} \\
\hline \hline & $\begin{array}{l}\text { Primary } \\
\text { Recession Area }\end{array}$ & $\begin{array}{l}\text { Secondary } \\
\text { Recession Area }\end{array}$ \\
\hline \hline Residual Recession Rate, ft/year & -0.7 & -0.3 \\
\hline Area Length, ft & 4,000 & 5,600 \\
\hline Volume Loss, cu yd/year & $-1,500$ & -900 \\
\hline Net Volume Loss, cu yd & $-147,000$ & $-88,000$ \\
\hline Potential Error, cu yd & 54,000 & 37,000 \\
\hline Potential Percent Error & 37 & 42 \\
\hline \hline
\end{tabular}

\section{Local Budget}

Two evaluation intervals for the local sediment budget are presented in this section. Volumetric change rates were divided and generalized into two time periods, a historical era (pre-1950) and a modern era (post-1980). These periods were chosen to minimize uncertainty associated with sand mining activities during the 1950s through late 1970s. This division should allow for the most reliable estimate of the longshore transport into the Mattituck Inlet littoral cell. Sediment budgets were complied in the Sediment Budget Analysis System (SBAS) (Rosati and Kraus 1999b).

Assumptions for the local sediment budget are as follows:

a. The longshore transport rate into Mattituck Inlet is approximately the sum of the impoundment rate, shoaling rate in the navigation channel, accretion rate in the offshore shoal complex, and annual removal rate by sand mining.

$b$. Federally permitted sand mining between the 1920s and 1940s removed approximately $85,000 \mathrm{cu} / \mathrm{yd}$ of material. This volume represents additional shoaling in the channel. Addition of this volume to dredging prior to 1950 increases shoaling rates approximately 1,900 $\mathrm{cu}$ yd/year.

c. Sediment accumulation rates on the offshore shoal are supported by sediment entering the cell in longshore transport.

d. Sediment transport rates out of the downdrift cells are lower in the modern era. Finer grained material has been removed from these cells since the jetties were constructed, resulting in a lag deposit of coarser material. Coarser material requires greater amounts of wave energy for transport; therefore, it is expected that transport rates out of the cell have decreased.

e. Sediment supply from bluff erosion is negligible. Bluffs in the downdrift impact areas have been stabilized by vegetation and installation of bulkheads. Bluffs are not present in the impoundment area. 
The sediment budget for the historical era is shown in Figure 54 and the modern era in Figure 55. Balancing of the budget for pre-1950 and post-1980 conditions resulted in net easterly longshore transport rates of 16,000 and $12,000 \mathrm{cu} \mathrm{yd} /$ year, respectively. Longshore transport rates into the cell are similar for both eras, and within the uncertainty of volume change rates at the site.

The gross longshore sediment transport rate $Q_{G}$ at the site can be estimated from the net easterly rate $Q_{E}$, and the net westerly rate $Q_{W}$, by the following relationship:

$$
Q_{G}=Q_{E}+Q_{W}
$$

Based on assessment of impoundment at the west jetty, wind direction and regional trends in shoreline orientation, it is assumed that transport to the east accounts for 75 percent of the gross rate, giving transport to the west as 25 percent of the gross rate. Under this assumption, the gross transport is estimated to range from 16,000 to $21,000 \mathrm{cu}$ yd/year, and westerly transport rates are between 4,000 and 5,000 cu yd/year at Mattituck Inlet. Other partitions of easterly and westerly transport, such as $60-40$ or $80-20$ could also be assumed and would not significantly change the overall conclusion.

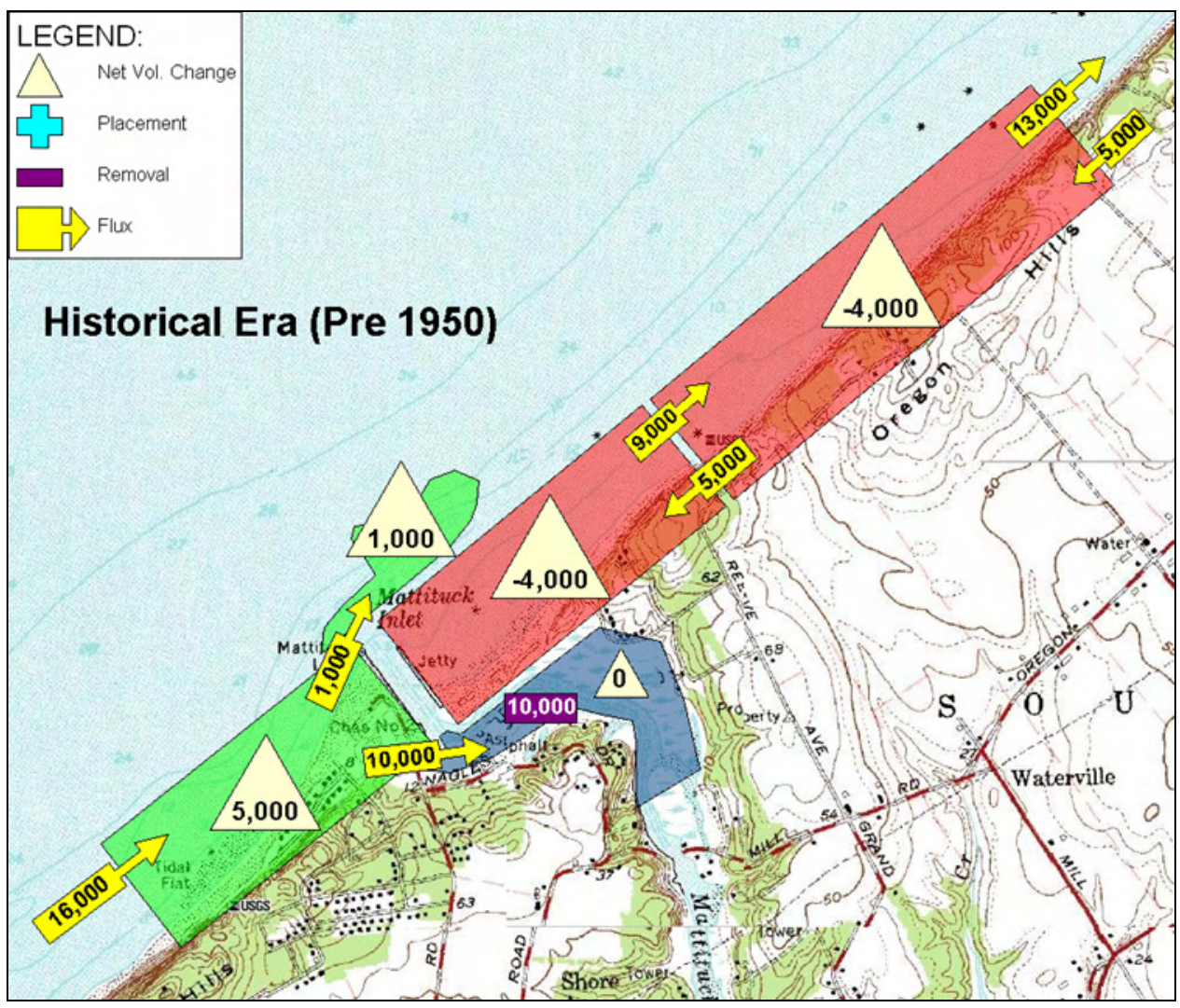

Figure 54. Budget for historical era (pre-1950) 


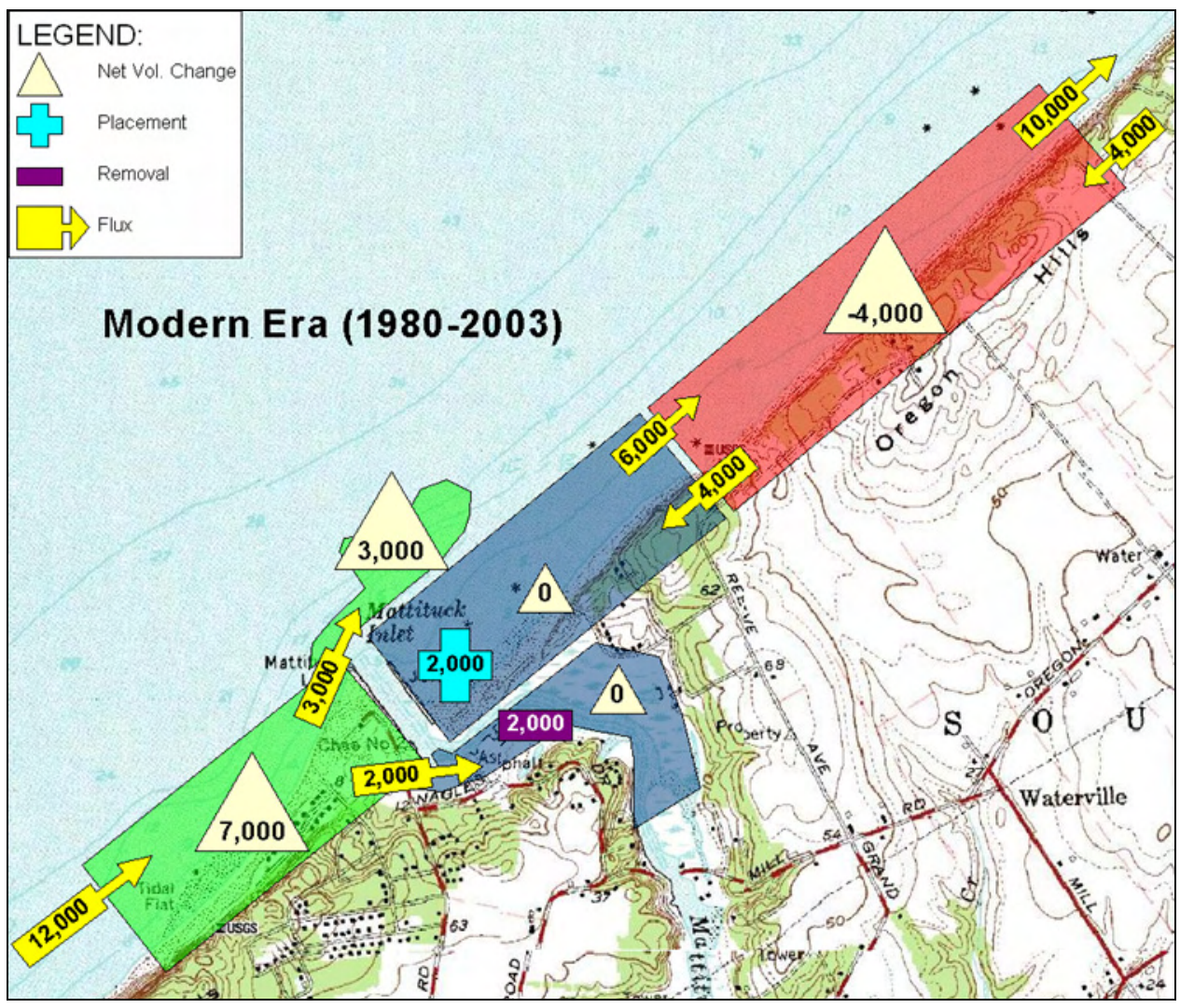

Figure 55. Sediment budget for modern era (post-1980)

\section{Regional Budget}

A regional sediment budget was calculated to compare and contrast changes in the vicinity of Mattituck Inlet to the region. Time intervals were the same as for the regional shoreline analysis, 1885-1965 (80 years) and 1965-2001 (36 years). The regional study area was divided into littoral cells by headland points, and at inlets present within study area.

Nine cells were defined between Mt. Sinai and Horton Point:

Cell 1. Mt. Sinai (Cedar Beach) to Rocky Point.

Cell 2. Rocky Point to Wading River Inlet (LILCO groins).

Cell 3. Wading River Inlet to Herod Point.

Cell 4. Herod Point to Roanoke Point.

Cell 5. Roanoke Point to Jacobs Point.

Cell 6. Jacobs Point to Mattituck Inlet.

Cell 7. Mattituck Inlet to Duck Pond Point.

Cell 8. Duck Pond Point to Goldsmith Inlet.

Cell 9. Goldsmith Inlet to Horton Point (or end of data). 
Volumetric change was calculated in each cell via the methods described above. Results for both intervals are listed in Table 17.

\begin{tabular}{||l|l|l|l||}
\hline Table 17 \\
Regional Volume Change
\end{tabular}

Volume losses were calculated for all cells during the 1885 to 1965 interval. The highest rate of erosion occurred from Herod Point to Roanoke Point $(31,000 \mathrm{cu} y \mathrm{~d} / \mathrm{year})$, whereas the coast east of Duck Pond Point experienced the lowest erosion rate (2,000 cu yd/year). Updrift of Mattituck, cell 6, from Jacobs Point to Mattituck Inlet, experienced an erosion rate of 15,000 cu yd/year despite material impounding at the east jetty. Downdrift of the inlet, cell 7 eroded at a

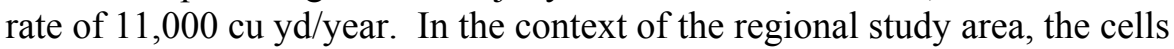
adjacent to Mattituck Inlet had the third and fourth highest rates of erosion.

Volume change calculations for the 1965 to 2001 interval showed five cells eroding, three accreting, and one with no significant change. The magnitude of volume change during this interval was lower than the previous interval, with six of the nine cells experiencing change rates less than 3,000 cu yd/year. The highest rates of erosion occurred from Mt. Sinai to Wading River Inlet (cells 1 and 2) with rates of 14,000 and $26,000 \mathrm{cu} \mathrm{yd} /$ year, respectively. Accretion occurred for both cells adjacent to Mattituck Inlet, with the updrift cell and downdrift cells accreting at rates of 7,000 and 1,000 cu yd/year. The lower magnitude of change rates during this interval suggests fewer or milder storms and or equilibration of the coastline.

Three alternatives are presented for the regional budget. Large supplies of material from shoreline recession, coupled with uncertainty regarding the fate of sediment along the coast, required logical iterative refinements of the regional budget. 


\section{Alt 1, Assumptions:}

a. Net longshore sediment transport is west to east.

b. All material supplied by recession of the shoreline is transported alongshore.

c. Sand and coarser material supplied by recession of the bluffs is conserved in the system. Supply rates are equivalent to $11,000 \mathrm{cu} \mathrm{yd} / \mathrm{mile} /$ year for sand and $2,500 \mathrm{cu} \mathrm{yd} / \mathrm{mile} /$ year for gravel. Total supply of material due to bluff recession is $13,500 \mathrm{cu} \mathrm{yd} /$ mile/year.

Application of assumptions from Alt 1 resulted in high rates of longshore sediment transport, incrementally increasing in the direction of transport. The transport rate at the eastern boundary for the 1885 to 1965 and 1965 to 2001 intervals was 520,000 and 458,000 cu yd/year, respectively. These rates are three to four times the highest (and not accepted) predicted longshore transport rate and are not supported by the wave climate in Long Island Sound. Given this, either assumption $b$ or $c$ is judged to be incorrect.

\section{Alt 2, Assumptions:}

a. Net longshore sediment transport is from west to east.

$b$. All material supplied by shoreline recession is transported alongshore.

c. Material provided by bluff recession is not conserved in the system. Finer material is lost offshore. Supply rates of sand and gravel are equal to $6,000 \mathrm{cu} \mathrm{yd} / \mathrm{mile} / \mathrm{year}$.

This alternative accounts for Davies (1972) observation of the difference in grain-size distributions between bluff and beach sediment at Old Field Point. Beach sediments were found to be coarser, lag deposits of bluff sediments. Analysis of grain size distributions found in Davies (1972) shows 100 percent of sampled beach sediments were coarser than the 1 to 2 phi size fraction $(0.3 \mathrm{~mm})$, and 99 percent of sediments were coarser than then 0 to 1 phi size fraction $(0.7 \mathrm{~mm})$. The grain-size distribution for bluff sediments showed that only 42 percent of the material was coarser than 1 phi. This results in a bluff supply rate of about $6,000 \mathrm{cu} \mathrm{yd} / \mathrm{mile} /$ year to the sediment budget, with 58 percent of the material $(9,000 \mathrm{cu} \mathrm{yd} / \mathrm{mile} /$ year) lost offshore. This number is a low estimate, as Tanski (1981) found a greater percentage of sand (72 percent on average) in bluffs east of Mt. Sinai than Old Field Point (52 percent).

Again, longshore transport rates through the region were calculated to be higher than physically plausible. For the $1885-1965$ period, the longshore transport rate at the eastern boundary was $285,000 \mathrm{cu} \mathrm{yd} /$ year, and for the 1965 to 2002 interval 223,000 cu/yd year. Further reductions of the bluff recession rate did not produce favorable results. Therefore, it is judged that assumptions $b$ and, possibly, $c$ are flawed. 


\section{Alt 3, Assumptions:}

a. Net longshore transport is from west to east.

$b$. A certain amount of material supplied is moved from the beach to offshore.

c. All material provided by bluff recession is not conserved in the system. Finer material is lost offshore. Supply rates are equivalent to $11,000 \mathrm{cu} \mathrm{yd} / \mathrm{mile} / \mathrm{year}$ for sand, and 2,500 cu yd/mile/year for gravel. Total supply of material due to bluff recession is $13,500 \mathrm{cu} \mathrm{yd} / \mathrm{mile} / \mathrm{year}$.

d. 84 percent of the sediment supplied by coastal recession is lost offshore.

Because of apparent large surpluses of material in the sediment budget, Alts 1 and 2 failed to represent processes along the north shore of Long Island. Davies (1972), Wise et al. (1978), Bokuniewicz and Gordon (1980), and Tanski (1981) recognized that long-term recession and limited sedimentation in harbors and marshes along the north shore indicated that material was not remaining in the littoral transport system. Given that sand is not conserved in the littoral zone, and harbors and marshes along the north shore of Long Island have not filled in, it must be assumed that this material moves offshore. Wise et al. (1978) estimated that 84 percent of material supplied by coastal recession is lost offshore.

Offshore movement of finer sediment is supported by the tendency for steep wave conditions in Long Island Sound. Average significant wave height $H$ and period $T$ were calculated from available wave data between January 1995 and January 1998. The average significant wave height and period during the 4-year interval were $0.8 \mathrm{ft}$ and $3 \mathrm{sec}$. Representative peak significant wave height and period during a storm were $4.5 \mathrm{ft}$ and $5 \mathrm{sec}$.

The potential for offshore transport can be evaluated using known empirical relationships. Dean (1973) established a well-accepted relationship between wave characteristics and beach shapes through a heuristic argument and smallscale laboratory data. This work established the fall speed parameter $N_{o}$ (Equation 4). Kraus et al. (1991) applied $N_{o}$ (based on significant wave height in deep water) to a field data set of 99 erosion and accretion events (Kraus and Mason 1991), exploring whether a beach is likely to erode or accrete by significant cross-shore transport. From this investigation, Kraus et al. (1991) established a criterion for $N_{o}$ : values of $N_{o}$ greater than or equal to 3.2 indicate probable erosion, and values less than 3.2 predict probable accretion. In addition, values above 4.0 indicate that erosion is highly probable, whereas values less than 2.4 indicate that accretion is highly probable.

The fall speed parameter is defined as:

$$
N_{O}=\frac{H_{O}}{w T}
$$

where

$$
\begin{aligned}
H_{o} & =\text { offshore significant wave height } \\
w & =\text { sediment fall velocity } \\
T & =\text { wave period }
\end{aligned}
$$


Grain sizes from very fine to very coarse sand were evaluated for cross-shore transport potential by applying the $N_{o}$ criterion to average and storm wave conditions in Long Island Sound. During average wave conditions, the criterion predicted offshore transport for grain sizes finer than 2 phi $(0.25 \mathrm{~mm}$, fine sand). During storms when the majority of transport occurs, the criterion predicted offshore transport for grain sizes finer than 1 phi $(0.5 \mathrm{~mm}$, medium sand $)$. These calculations support the net long-term offshore transport of sand sized particles along the north shore of Long Island as hypothesized independently by several researchers.

Results for Alt 3 were favorable, with magnitudes of longshore transport ranging from 3,000 cu yd/year to 23,000 cu yd/year. Although an 84 percent loss of material offshore appears high, it is consistent with the resulting longshore transport rates. Combinations of reductions in bluff supply rates and offshore transport rates did not make significant differences. Offshore losses of sediment must remain at high levels in order for the budget to balance. For example, a bluff supply rate of $500 \mathrm{cu} \mathrm{yd} / \mathrm{mile} / \mathrm{year}$ would require offshore losses of 50 percent of material in transport to balance the budget. Coastal evolution, morphology, the literature, and wave characteristics in Long Island Sound are consistent in supporting such losses.

Results of the regional budget are shown in Table 18 (1885 to 1965) and Table 19 (1965 to 2001). Sediment flux values in the $Q_{\text {out }}$ columns represent the longshore sediment flux out of the cell. Cell 6 terminates at Mattituck Inlet, with a longshore transport rate of $16,000 \mathrm{cu}$ yd/year, similar to magnitude of the longshore transport rate calculated in the local budget cell.

\begin{tabular}{|l|l|l|l|c||}
\hline \hline \multicolumn{4}{||l||}{$\begin{array}{l}\text { Table 18 } \\
\text { Regional Budget, 1885-1965 }\end{array}$} \\
\hline \hline \\
\hline \hline
\end{tabular}




\begin{tabular}{|c|c|c|c|c|}
\hline \multicolumn{5}{|c|}{$\begin{array}{l}\text { Table } 19 \\
\text { Regional Budget, 1965-2001 }\end{array}$} \\
\hline Cell & $\begin{array}{l}\text { Volume } \\
\text { Change, } \\
\text { cu yd/year }\end{array}$ & $\begin{array}{l}\text { Bluff } \\
\text { supply, } \\
\text { cu yd/year }\end{array}$ & $\begin{array}{l}\text { Offshore } \\
\text { Loss, } \\
\text { cu yd/year }\end{array}$ & $\begin{array}{l}\text { Qout, } \\
\text { cu yd/year }\end{array}$ \\
\hline 1 & $-14,000$ & 36,000 & 42,000 & 8,000 \\
\hline 2 & $-26,000$ & 72,000 & 89,000 & 17,000 \\
\hline 3 & 2,000 & 25,000 & 34,000 & 6,000 \\
\hline 4 & $-3,000$ & 104,000 & 95,000 & 18,000 \\
\hline 5 & 0 & 26,000 & 37,000 & 7,000 \\
\hline 6 & 7,000 & 76,000 & 64,000 & 12,000 \\
\hline 7 & 1,000 & 37,000 & 40,000 & 8,000 \\
\hline 8 & $-1,000$ & 36,000 & 38,000 & 7,000 \\
\hline 9 & $-2,000$ & 10,000 & 16,000 & 3,000 \\
\hline
\end{tabular}

\section{Summary}

Sediment budgets were compiled for the north shore of Long Island in the Mattituck littoral cell and for a regional reach extending from Mt. Sinai to Horton Point. The regional budget provided information on the larger scale, long-term coastal processes around the study site. Large, offshore-directed fluxes of sediment are required to balance the regional budget and to approximate estimated longshore transport rates into the Mattituck littoral cell.

Volumes of sediment lost or gained from impoundment, erosion, shoaling, dredging, and sand mining were evaluated for the Mattituck Inlet littoral cell. Federal dredging activities removed approximately $391,000 \mathrm{cu}$ yd of material after 1921. Subsequent to 1946, dredged material has been placed directly on the downdrift beach ( 209,000 cu yd). Sand mining has occurred at the site under Federal permits and by local commercial entities. Federally permitted mining occurred between 1925 and 1943, removing an estimated 85,000 cu yd. Local entities mined the impoundment fillet, with a documented removal of 243,000 cu yd between 1960 and 1975. Additional undocumented mining could range from 20,000 to $160,000 \mathrm{cu}$ yd. Mining (permanent removal from system) by other commercial sand and gravel and asphalt industries at the site could potentially total 200,000 to $500,000 \mathrm{cu}$ yd. Offshore shoaling rates were determined from bathymetric change between 1927, 1969 and 2002. Calculations showed that approximately 3,000 cu yd/year of material was transported across the inlet and deposited in the bypassing bar.

Sediment impoundment updrift of the inlet and sediment loss from erosion downdrift of the inlet were calculated. Sediment impoundment behind the east jetty at Mattituck Inlet was estimated by GIS analysis of fillet area and shoreline change rates. The best estimate of total impoundment is $473,300 \mathrm{cu} y d$, with a potential maximum of 746,000 cu yd (unknown amount of fillet mining).

Volume losses in the area of project influence downdrift of the inlet were estimated by analysis of shoreline change rates. Total volume losses in the primary erosion area (4,000 ft east of inlet) and in secondary erosion area $(5,600 \mathrm{ft}$ east of primary area) were calculated at 147,000 ( \pm 53 percent $)$ and 
$88,000 \mathrm{cu}$ yd ( \pm 133 percent), respectively. Total losses were estimated at $235,200 \mathrm{cu}$ yd ( \pm 80 percent).

The rate of eastward longshore transport into the vicinity of the inlet, calculated from known quantities of sediment impoundment updrift of the east jetty, channel shoaling, and offshore shoaling, was between 14,000 and $16,000 \mathrm{cu}$ yd/year. This range of values agrees with the magnitude of sediment transport entering the cell as determined by the regional budget. 


\section{Future Without-Project Condition}

This chapter describes the anticipated state of the beach downdrift of Mattituck Inlet if no modifications are made to current dredged material management practice. Site conditions and management practice after 1980 are evaluated and projected to estimate future conditions of the beach for 1.8 miles $(9,600 \mathrm{ft})$ east of the inlet.

Present dredged material management practice includes periodic channel maintenance, dredging, and placement of material on the downdrift beach. The last three dredging activities had an approximate 10-year interval (1980, 1990, $2004)$ and removed a total of $51,100 \mathrm{cu}$ yd $(24,100,13,200$, and $13,800 \mathrm{cu}$ yd, respectively). The sediment budget for the modern era (post-1980) should allow for evaluation of shoreline response to placement of dredged material on the downdrift beach (Figure 55). Volume change for this budget was calculated from the 1980 and 2003 shorelines. The 1980 shoreline is representative of conditions 2 months prior to placement, whereas the 2003 shoreline is representative of conditions 1 year prior to placement. These two shorelines effectively capture conditions at the site between dredged material placements.

At present, shoaling rates in the Mattituck navigation channel and the resulting maintenance dredging volumes are insufficient to mitigate erosion in both the primary $(4,000 \mathrm{ft}$ east of inlet) and secondary $(4,000-9,600 \mathrm{ft}$ east of inlet) erosion areas. Dredged-material placement on the downdrift beach has mitigated erosion in the primary erosion area. In the modern era budget, shoreline change rates in the primary erosion area have been stabilized. However, the secondary erosion area is experiencing shoreline recession at a rate of $1.5 \mathrm{ft} /$ year. This rate is $0.5 \mathrm{ft} /$ year greater than the long-term regional recession rate. Present rates of sediment bypassing $(2,200 \mathrm{cu} \mathrm{yd} /$ year $)$ via dredged material placement are not equal to the average annual eastward longshore sediment transport rates $(12,000$ to $16,000 \mathrm{cu} \mathrm{yd} /$ year $)$. It is expected that this reach of shoreline will continue to erode as long as sediment bypassing rates are unequal to the local net longshore sediment transport rates. Increased erosion due to the sediment deficit along the downdrift beach will result in further recession of the shoreline, narrower beaches, and exposure of the bluff base to wave attack. Failure of downdrift bulkheads and increased bluff recession along the subject shoreline should be expected in the long term (decades). As a result, private property and structures within the primary and secondary erosion areas would be threatened within the next 50 to 100 years. 
Future shoreline conditions can be estimated by the shoreline change rate and time interval of interest. A 50-year hwl shoreline position was calculated based on shoreline change rates after 1980. In the impoundment area, shoreline advance of $85 \mathrm{ft}$ was estimated. The calculated shoreline is at the approximate location of mlw for the 2004 April condition (Figure 56). Advance of the hwl shoreline to this position would result in an mlw shoreline position at the tip of the west jetty. Such a condition would increase shoaling in the navigation channel, approaching rates observed in the early half of the century $(7,000 \mathrm{cu}$ $\mathrm{yd} /$ year) when a similar condition existed. In the primary recession area, the estimated 50-year shoreline was similar to the present (Figure 57). Present management practice of dredged material placement has stabilized the beach directly downdrift of the inlet. Shoreline recession is expected within the secondary erosion area, estimated at $75 \mathrm{ft}$ during the next 50 years (Figure 58), a result of the sediment deficit in this littoral cell caused by sediment impoundment updrift of Mattituck Inlet.

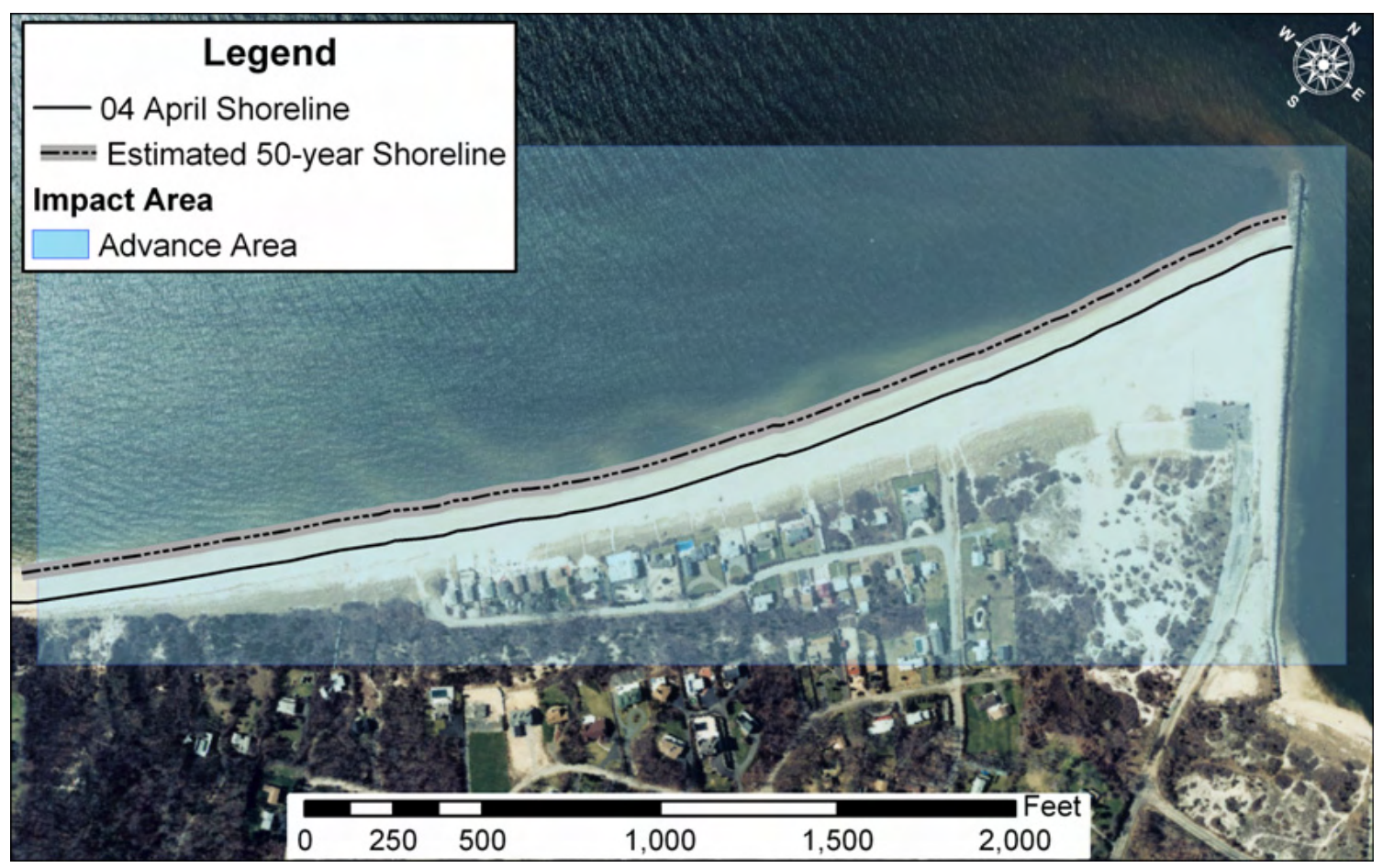

Figure 56. Estimated 50-year shoreline advance in impoundment fillet 


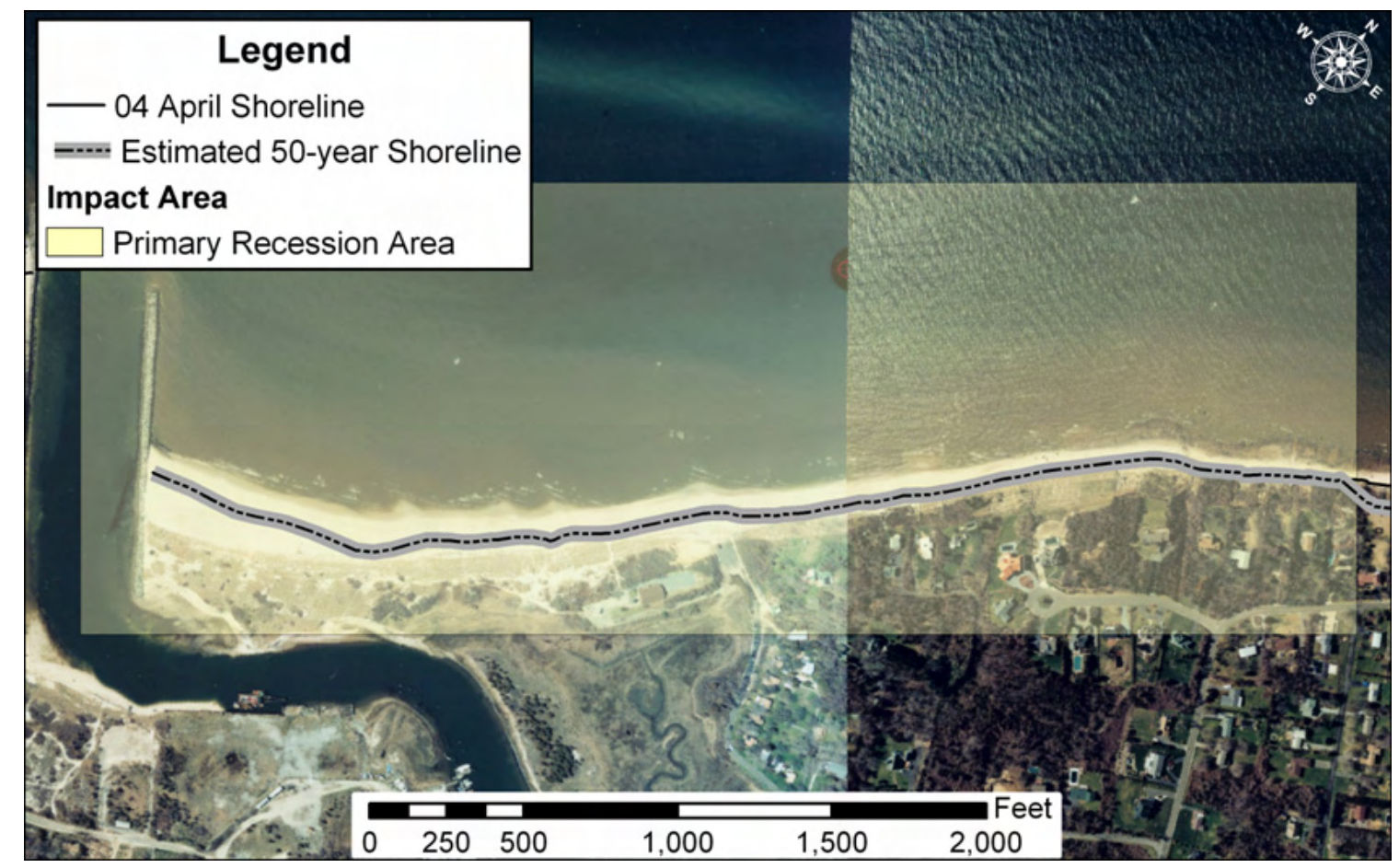

Figure 57. Extrapolated 50-year shoreline based on present conditions produces little expected change in primary erosion area

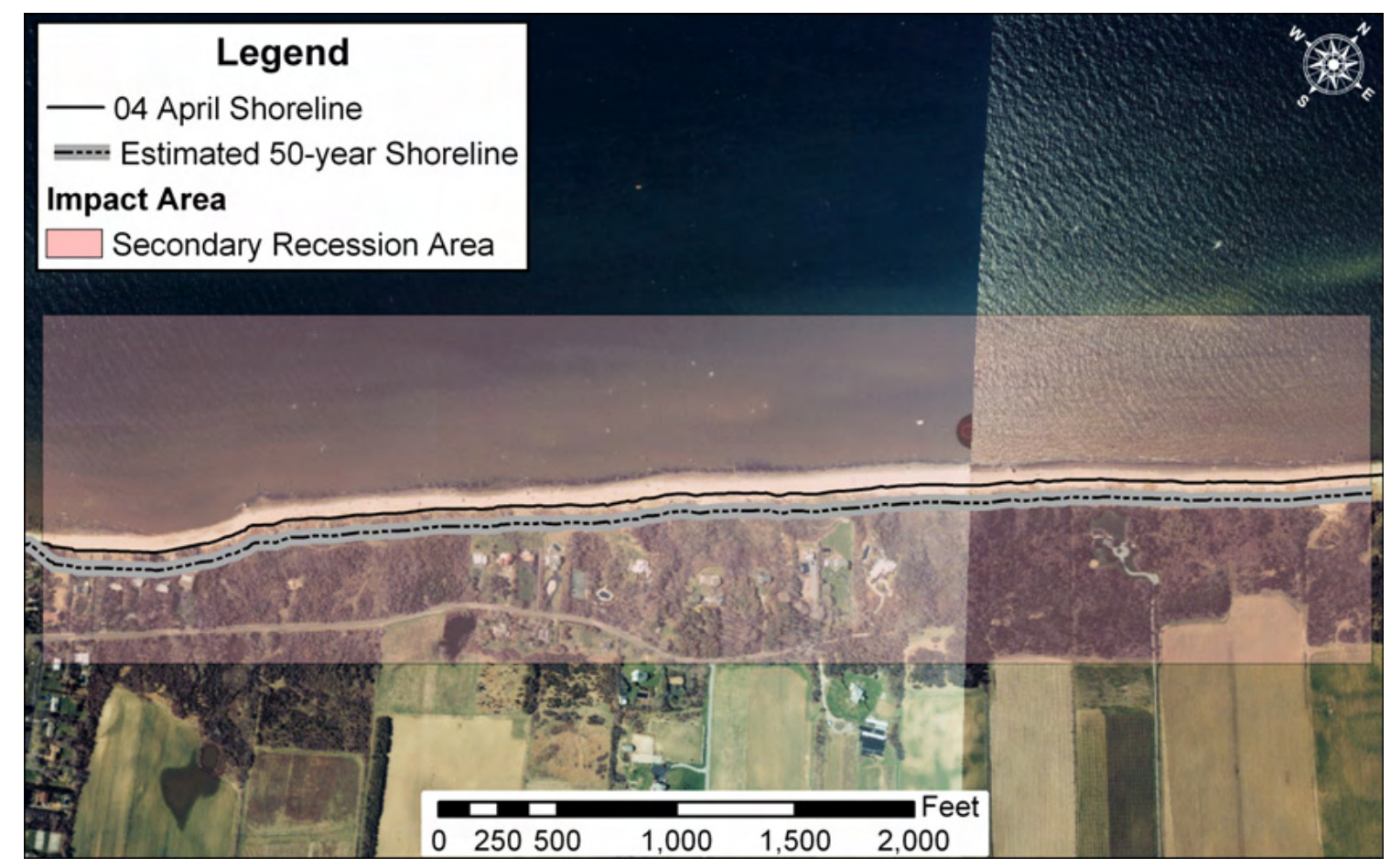

Figure 58. Estimated shoreline losses in secondary recession area (50 years, based on present-condition rate) 
A landward breach adjacent to the east jetty occurred circa 1935

(Morgan et al. 2005). Present and future conditions were evaluated to determine the likelihood of a reoccurrence of a breach. Figure 59 shows site conditions in 1941, approximately 6 years after the initial flanking and prior to repairs made in 1946. The initial jetty design did not account for the extent of shoreline recession directly downdrift of the east jetty, a result of a lack of sediment bypassing around the inlet. At the time of construction (1900 to 1906), the net longshore sediment transport direction and rate were probably unknown. Furthermore, flanking of the east jetty removed the possibility of impoundment of west-directed longshore sediment transport and exacerbated the condition of the beach directly east of the inlet.

In 1946, the jetty was repaired and extended landward by $280 \mathrm{ft}$, and the downdrift beach was nourished with dredged material. Figure 60 shows the position of the land-water interface leading up to and after the breach to the present day site conditions. The present-day shoreline is seaward of the shoreline position in 1947 along the barrier shoreline east of Mattituck Inlet. The landward extension of the east jetty, combined with the practice of dredged material placement on the downdrift beach, effectively stabilized and advanced the downdrift beach in the 58 years subsequent. Given the present condition of the beach, configuration of the inlet, and dredged material disposal practice, it is doubtful that breaching will reoccur at the site. However, vulnerability to storm waves increases towards the end of a sediment bypassing cycle. Additional bypassing and placement of material would strengthen the integrity of the beach and dunes along the barrier directly adjacent to the inlet and prevent a weakened condition similar to that in the late 1930 s early 1940 s from reoccurring.

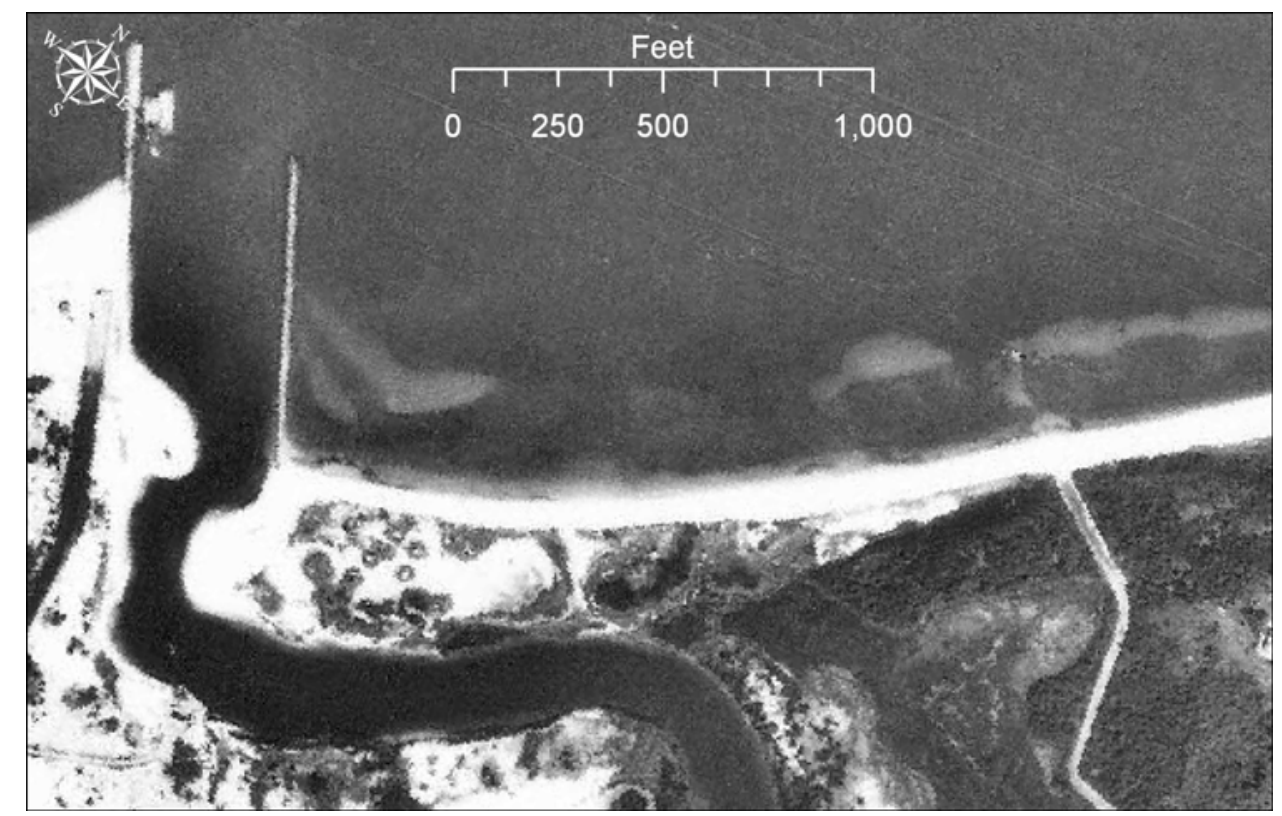

Figure 59. Landward flanking of east jetty, 1941 


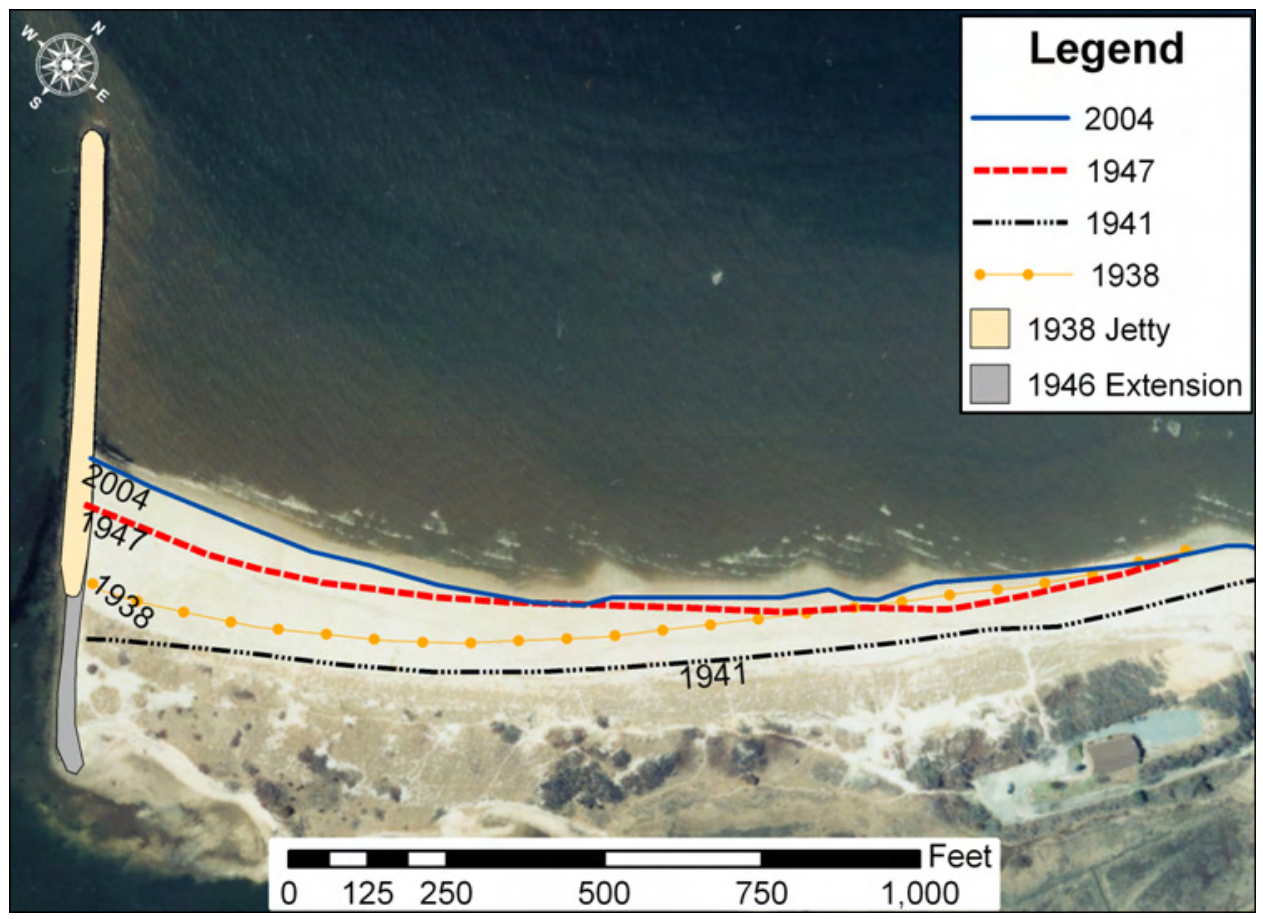

Figure 60. Present shoreline and beach compared to shoreline position in 1938 and in 1940s

A sediment deficit developed and has persisted downdrift of Mattituck Inlet in response to impoundment of sediment updrift of the west jetty. Present management practice at Mattituck Inlet places dredged material on the downdrift beach at about a 10-year interval. This practice bypasses sediment across the inlet at an approximate rate of 2,200 cu yd/year, or at 18 percent of the average annual eastward longshore transport rate at the site. Although this practice has effectively stabilized shore recession in the primary impact area, elevated shore recession rates persist in the secondary impact area. Evaluation of the present shoreline against conditions preceding the 1935 breach indicates that a breach is not imminent at the site. However, breaching vulnerability increases towards the end of a sediment bypassing cycle. Reoccurrence of a breach would be prevented by strengthening of the beach and dunes directly downdrift of the inlet.

A 50-year shoreline position was estimated based on shoreline change rates after 1980. Estimated shoreline advance of the impoundment fillet indicates that the area will completely fill within this time frame. As a result, shoaling rates in the navigation channel are expected to increase. Although the shoreline position in the primary recession area has stabilized, estimated shoreline recession in the secondary impact area is approximately $75 \mathrm{ft}$ in the next 50 years. Unless sediment bypassing rates are increased, downdrift beaches will continue to experience rates of erosion exceeding the regional average. 


\section{Assessment of Federal Responsibility}

Federal responsibility for erosion downdrift of the Mattituck Inlet navigation project is assessed in this section by two approaches. The first approach evaluates the response of the adjacent shorelines to the project. This approach is termed "explicit" because it gives a direct measure of shoreline recession and advance, hence, eroded and accreted volume along an identifiable extent of coast, respectively, under certain standard assumptions. This evaluation includes measured shoreline change and the volume of material impounded updrift of the inlet. The second approach considers impacts to the downdrift shoreline evaluated through a sediment budget. This method is termed "implicit" because it is based on transport rates alongshore and across shore that cannot be directly measured. Removal of material by maintenance dredging, as well as sand and gravel mining under both Federal and local permits, are addressed within the implicit approach. The implicit method can account for total volume derived to a downdraft coast, but not along a particular extent.

\section{Explicit Assessment by Shoreline Change}

This section assesses the responsibility of the Federal government for damages downdrift of the Mattituck Inlet navigation channel by measurable changes to the adjacent shoreline conditions. Shoreline change and the volume of material impounded updrift of the inlet are considered. Known volumes of sediment removal by commercial mining are discussed.

A regional shoreline change rate was calculated for the time interval of the existence of the Mattituck Inlet Federal navigation project. The regional analysis extended from Mt. Sinai Harbor, the western limit, to Horton Point, the eastern limit. It was found in Chapter 2 that for the period 1885 to 2001, the average rate of shoreline recession in the region was $1.0 \mathrm{ft} /$ year $( \pm 0.4 \mathrm{ft} /$ year).

Shoreline change in the project area was evaluated for the period 1838 to 2004 from a series of 14 shoreline data sets. This analysis resulted in the delineation of an extent of impact of the Federal navigation project at Mattituck Inlet of 9,600 ft downdrift of the inlet. This extent was subdivided into a primary and secondary recession area based on the magnitude of the shoreline change rates. The primary recession area extends for $4,000 \mathrm{ft}$ to the east, with average recession rates of $1.7 \mathrm{ft} /$ year. The secondary recession area extends for another $5,600 \mathrm{ft}$ eastward of the primary area, with a lower average recession rate of 
$1.3 \mathrm{ft} /$ year $( \pm 0.4 \mathrm{ft} /$ year). Updrift of the inlet, the area of impoundment was found to extend for approximately $3,500 \mathrm{ft}$ to the west. The average rate of shoreline advance in this area was $1.8 \mathrm{ft} /$ year, $\pm 0.4 \mathrm{ft} /$ year (1885 to 2004).

To evaluate the amount of shoreline change attributable to the Federal navigation project, the residual shoreline change rate $\Delta \mathrm{y}_{R}$ was determined by:

$$
\Delta y_{R}=\Delta y_{L}-\Delta y_{L T R}
$$

where $\Delta \mathrm{y}_{L T R}$ is the long-term regional recession rate, and $\Delta \mathrm{y}_{L}$ is the local recession rate. The residual shoreline change rate was determined for the two impact areas downdrift of the inlet. Values are reported in Table 20. Within these areas, the percent of recession $R_{F e d}$ attributable to the Federal navigation project was defined as the percent of the long-term local recession rate represented by the residual rate in each area:

$$
R_{F e d}=\frac{\Delta y_{R}}{\Delta y_{L}} 100
$$

In the primary and secondary recession areas, the percent of recession attributable to the inlet was found to be 41 percent and 23 percent, respectively (Table 20). Percent error for the recession rate represents the uncertainty in shoreline positions for that interval. Percent error for calculated volume loss was calculated from the product of the percent error of the recession rate and

\begin{tabular}{|c|c|c|}
\hline \multicolumn{3}{|c|}{$\begin{array}{l}\text { Table } 20 \\
\text { Residual Recession Rates and Percent of Recession } \\
\text { Attributed to Federal Project (1885-2004) }\end{array}$} \\
\hline & $\begin{array}{l}\text { Primary Recession } \\
\text { Area }\end{array}$ & $\begin{array}{l}\text { Secondary Recession } \\
\text { Area }\end{array}$ \\
\hline Recession Rate, ft/year & 1.7 & 1.3 \\
\hline Percent Error & 24 & 31 \\
\hline Residual Recession Rate, ft/year & 0.7 & 0.3 \\
\hline Percent attributed to Federal Project & 41 & 23 \\
\hline Calculated Volume Loss, cu yd & 147,000 & 88,000 \\
\hline Percent Error & 37 & 42 \\
\hline
\end{tabular}
calculated volume loss.

Initial dredging (new work) of the inlet navigation channel at Mattituck occurred in 1907 and 1914. Maintenance dredging began in 1921 and continues through present. In total, Federal dredging activities removed approximately $432,000 \mathrm{cu}$ yd of material from the channel. Placement of dredged material on the beach directly downdrift of the inlet began in 1946 and continues through present. New York District documents as described in Chapter 4 indicate that $173,500 \mathrm{cu}$ yd of this material was placed on the downdrift beach.

Volumetric losses and gains were calculated in both the impoundment fillet and the area of shore recession. Volumetric changes $\Delta V$ were derived from 
shoreline change data assuming uniform recession of the beach profile over the depth of active transport $D_{A}$ :

$$
\Delta V=\frac{\Delta y D_{A} L}{27}
$$

where $\Delta y$ is the shoreline change rate, $L$ is the length of shoreline, and 27 is the conversion factor from cubic feet to cubic yards. The net volume of material eroded from the downdrift area was $235,000 \mathrm{cu}$ yd $( \pm 91,000 \mathrm{cu}$ yd) with $147,000 \mathrm{cu}$ yd $( \pm 54,000 \mathrm{cu} \mathrm{yd})$ lost from the primary recession area and $88,000 \mathrm{cu}$ yd ( $\pm 37,000 \mathrm{cu}$ yd) lost from the secondary recession area. Because the volume of material lost from downdrift beaches is derived from shoreline change data, it inherently accounts for dredged material placed on the beach directly downdrift of Mattituck Inlet.

Volume gains were also estimated in the impoundment area updrift of the inlet. It was calculated that a total of $586,700 \mathrm{cu}$ yd $( \pm 86,400 \mathrm{cu} \mathrm{yd})$ of sediment was trapped between 1906 and 2004. Documented mining of the impoundment fillet by non-Federal local entities occurred between 1960 and 1975. Subtraction of the volume of material removed by non-Federal local entities reduces the total volume of impounded sediment to $347,700 \mathrm{cu}$ yd. Volume gains in the impoundment fillet are similar to the total volume lost from downdrift beaches if placement of dredged material had not occurred (408,700 cu yd).

Assessment of shoreline change data determined that the Federal navigation channel at Mattituck Inlet is responsible for 41 and 23 percent of shoreline recession in the identified primary and secondary downdrift areas of erosion, respectively. Volume losses associated with the residual recession rates attributable to the Federal navigation channel were calculated at 235,000 cu yd within the identified areas. It is possible that the impact of the Mattituck Inlet navigation project is not completely represented by shoreline position change within the identified areas of impact. Estimated volume losses downdrift are less than half of the impoundment volumes updrift. Reasons for this are lack of representation of losses of material from bluff recession, the influence of sediment mining activities, and longshore transport reversals. Because of these limitations in the explicit approach, an implicit assessment of volume lost to downdrift beaches based on the sediment budget is presented in the following section.

\section{Implicit Assessment by Sediment Budget}

Federal responsibility can also be evaluated by the volume of sediment estimated to have been denied to the downdrift beaches by the construction and maintenance of the Federal navigation project at Mattituck Inlet. Longshore transport rates determined from the sediment budget provide a means to assess the total amount of sediment diverted from downdrift beaches by construction of the Mattituck Inlet navigation project. In addition, evidence indicates that commercial mining interests removed large volumes of sediment from the inlet channel. The potential significance of this removal of material, as well the relevance to the responsibility of the Federal government for downdrift erosion, can be evaluated through a sediment budget. 


\section{Error}

In the following sections, error estimates were calculated by combining uncertainties associated with the processes analyzed to estimate longshore transport rates (impoundment rates, channel shoaling rates, and bathymetric change rates). The average error associated with calculation of impoundment rates (Chapter 4) was approximately 20 percent. Offshore accumulation rates were assigned an error of 35 percent based on uncertainties in data collection, positioning, and realignment of depths to a common datum. Shoaling rates determined from dredging records were assumed to have an error of 10 percent.

These percentages were used to calculate the magnitude of error within each rate. The rms error for the average annual longshore transport rate was then calculated from these magnitudes. For the historical and modern eras, the rms error in the longshore transport rate was equivalent to approximately $1,500 \mathrm{cu} \mathrm{yd} /$ year and $1,300 \mathrm{cu} \mathrm{yd} /$ year, respectively. This translates to 9 (historical) and 11 (modern) percent of the average annual LST rate. These error percentages were applied to estimated volume totals to calculated total volume error.

\section{Longshore sediment transport rates}

Longshore transport rates were calculated within historical (pre-1950) and modern (post-1980) time periods (Chapter 4). These periods were chosen to minimize uncertainty associated with sand mining activities during the 1950s through late 1970s. In the historical era sediment budget, the average annual eastward longshore transport rate at Mattituck Inlet was calculated at $16,000 \mathrm{cu} \mathrm{yd} /$ year. Average annual gross and westward directed transport rates were calculated from the easterly rate at 21,000 and 5,000 cu yd/year, respectively. Gross and westward transport rates are based on an assumed 75 percent eastward and 25 percent westward transport distribution. The impoundment and shoaling rates in the navigation channel (dredging) during this era were 5,000 and 10,000 cu yd/year, respectively. Material dredged from the navigation channel was disposed in the nearshore or in upland sites. Evidence suggests that some amount of material disposed offshore may have returned to the littoral system (Chapter 4). Offshore losses were equivalent to $1,000 \mathrm{cu} y d / y e a r$ during this interval. If it is assumed that all of this material was removed from the system, the Federal navigation project is responsible for a 94 percent ( \pm 13 percent) reduction in longshore sediment transport across the inlet during this historical period.

During the modern era (post-1980), the average annual eastward longshore sediment transport rate at Mattituck Inlet was estimated at 12,000 $\mathrm{cu}$ yd/year. Average annual gross and westward-directed transports were calculated at 16,000 and 4,000 cu yd/year, respectively. The impoundment rates updrift of the west jetty was estimated at $7,000 \mathrm{cu} y d / y e a r$, and the shoaling rate in the navigation channel was $2,000 \mathrm{cu}$ yd/year. Material removed from the channel in this era was placed on the downdrift beach; therefore, shoaling rates are not considered a removal from the system. Offshore losses were equivalent to $3,000 \mathrm{cu}$ yd/year during this era. Given this, the Federal navigation project was responsible for a 58 percent $( \pm 13$ percent) reduction in longshore sediment transport across the inlet during the modern era, and present management 
practice bypasses 17 percent of the average annual eastward longshore sediment transport rate across the inlet.

The percentage of longshore sediment transport is a foundation on which to determine the potential volume of sediment deprived to downdrift beaches. The following section provides a synthesis of the sinks in the sediment budget to estimate the total volume of sediment lost to downdrift beaches and the extent of Federal responsibility.

\section{Total volume lost to downdrift beaches}

Commercial sand and gravel mining occurred at the site from the 1920s through at least the $1940 \mathrm{~s}$. In Chapter 1 , it was estimated that approximately $85,000 \mathrm{cu}$ yd was removed from the system under Federal permits allowing dredging within the channel entrance. Sand and gravel mining also occurred under local permits. Documented mining of the impoundment fillet between 1960 and 1975 removed an estimated 243,000 cu yd. It is possible that this mining began earlier, and an additional 20,000 to $160,000 \mathrm{cu}$ yd of material may have been mined, resulting in a total removal of 263,000 to $403,000 \mathrm{cu}$ yd. Infrastructure for sand and gravel mining and asphalt production was present at the site from the 1950s through the 1970s. Analysis of channel stability (Morgan et al. 2005) indicated that the tidal prism at Mattituck Inlet does not support the existing channel cross-section, implying that the channel has been overdredged. This overdredging can be attributed to sand mining activities. Although removal of material by these industries is potentially large, estimated between 200,000 and 500,000 cu yd, this material was not directly derived sediment in littoral transport. Therefore, if not removed, this material would have remained in the inlet channel and would not have been bypassed to downdrift beaches. However, removal of this material from the inlet channel may have also increased shoaling rates, which, in turn, would deprive additional material from downdrift beaches. Given these complications, the impact of sand mining on the sediment budget at Mattituck Inlet is difficult to resolve and has a large amount of uncertainty. Sediment removal from the Mattituck Inlet budget is summarized in Table 21.

Non-Federal (local) sand mining of the inlet channel and impoundment fillet removed between 443,000 and 903,000 cu yd of sediment. In contrast, removal of sediment from the littoral system under the authority of the Federal government is equal to $610,000 \mathrm{cu}$ yd. The magnitude of volume loss in the sediment budget due to sand mining by non-Federal parties is equal to, and potentially greater than, the volume of material eroded from the downdrift beach. If this material had not been removed by commercial mining activities, it is likely that (a) the material would have been dredged from the navigation channel and bypassed to downdrift beaches, or (b) the impoundment fillet would have completely impounded and bypassed a portion of the material to downdrift beaches. In light of this difference, one could conclude that the responsibility of the Federal government for erosion downdrift of the Mattituck Inlet navigation project is limited. 


\begin{tabular}{|c|c|c|}
\hline \multicolumn{3}{|c|}{$\begin{array}{l}\text { Table } 21 \\
\text { Summary of Sediment Removal from Local Budget }\end{array}$} \\
\hline Sink & Comment & Volume, cu yd \\
\hline \multirow[b]{2}{*}{ Impoundment } & Including mining & 587,000 \\
\hline & Not including mining & 344,000 \\
\hline \multirow[b]{2}{*}{ Dredging } & Total & 391,000 \\
\hline & Bypassed & 209,000 \\
\hline Federally permitted mining $^{1}$ & & 85,000 \\
\hline Mining of fillet ${ }^{2}$ & & $243,000-403,000$ \\
\hline Mining industry in channel ${ }^{3}$ & & $200,000-500,000$ \\
\hline \multirow[b]{3}{*}{ Total } & Federal & 610,000 \\
\hline & Non-Federal & $443,000-903,000$ \\
\hline & Total & $1,073,000-1,513,000$ \\
\hline \multirow[b]{3}{*}{ Total known } & Federal & 181,000 \\
\hline & Non-Federal & 243,000 \\
\hline & Total & 424,000 \\
\hline \multirow[b]{3}{*}{ Total estimated } & Federal & 85,000 \\
\hline & Non-Federal & $220,000-660,000$ \\
\hline & Total & $305,000-745,000$ \\
\hline \multirow[b]{3}{*}{ Downdrift Erosion } & Primary & 147,000 \\
\hline & Secondary & 88,200 \\
\hline & Total & 235,200 \\
\hline \multicolumn{3}{|c|}{$\begin{array}{l}{ }^{1} \text { In inlet channel entrance, estimated. } \\
{ }^{2} \text { High value, estimated. } \\
{ }^{3} \text { In inlet channel, estimated. }\end{array}$} \\
\hline
\end{tabular}

However, morphological evidence shows that the Federal navigation project west jetty has impounded sediment since construction. The total volume $V_{\text {tot }}$ of sediment attributable to the construction and maintenance of the Federal navigation channel can be estimated by the following:

$$
V_{\text {tot }}=Q_{\text {resp }} d t
$$

where $Q_{\text {resp }}$ is the average annual rate of longshore transport reduction attributed to the Federal navigation project, multiplied by the time interval, $d t$. The calculated percentages of average annual longshore sediment transport were used to determine the potential reduction of volume to downdrift beaches during the 1906 to 1950 and 1950 to 2004 (downdrift placement began in 1946) intervals. These volumes were calculated at $662,000 \mathrm{cu}$ yd $( \pm 62,000 \mathrm{cu}$ yd) and $376,000 \mathrm{cu}$ yd $( \pm 41,000 \mathrm{cu} \mathrm{yd})$, respectively, resulting in a total $\left(V_{t o t}\right)_{1}$ of $1,038,000 \mathrm{cu}$ yd $( \pm 103,000 \mathrm{cu}$ yd) of sediment attributable to the Federal navigation project. 
The total volume of sediment attributable to the Federal navigation project at Mattituck Inlet can also be estimated by the following:

$$
V_{\text {tot }}=V_{i}+V_{d}+V_{m}
$$

where $V_{i}$ is the volume of material impounded behind the updrift jetty, $V_{d}$ is the volume of material dredged from the navigation channel, and $V_{m}$ is the volume of material mined from the navigation channel and/or the impoundment fillet. If mining volume is limited to documented removal (impoundment mining, $243,000 \mathrm{cu} \mathrm{yd}),\left(V_{t o t}\right)_{2}$ is equal to $978,000 \mathrm{cu}$ yd $( \pm 219,000 \mathrm{cu} \mathrm{yd})$ of sediment. This value is similar to the $\left(V_{t o t}\right)_{1}$ determined by the volume of longshore sediment transport lost to downdrift beaches. Much uncertainty exists regarding the quantities of sediment mined by non-Federal entities from the navigation channel and impoundment fillet. Inclusion of estimated amounts of federally permitted mining during the $1920 \mathrm{~s}$ to $1940 \mathrm{~s}\left(85,000 \mathrm{cu}\right.$ yd) would increase $\left(V_{t o t}\right)_{2}$ to $1,063,000 \mathrm{cu}$ yd $\left( \pm 238,000 \mathrm{cu}\right.$ yd) of sediment $\left(V_{t o t}\right)_{2 a}$. Low and high estimates of $V_{t o t}$ including estimates of non-Federal mining are 1,526,000 $\left(V_{t o t}\right)_{3 a}$ and $1,966,000 \mathrm{cu}$ yd $\left(V_{t o t}\right)_{3 b}$, respectively. These values are summarized in Table 22 .

The $V_{\text {tot }}$ values in Table 22 summarize the total amount of volume loss attributable to the inlet and do not take into consideration placement of dredged material on downdrift beaches, offshore losses, and known non-Federal sand removal. These volumes should be removed from the total to determine the volume of sediment that is attributable to the Federal navigation channel at Mattituck Inlet.

\begin{tabular}{|c|c|}
\hline \multicolumn{2}{|c|}{$\begin{array}{l}\text { Table } 22 \\
\text { Total Volume Loss Attributable to Mattituck } \\
\text { Inlet Federal Navigation Project }\end{array}$} \\
\hline$V_{\text {tot }}$ & Volume, cu yd \\
\hline$\left(V_{\text {tot }}\right)_{1}$ Longshore transport lost to downdrift beaches & $1,038,000$ \\
\hline$\left(V_{\text {tot }}\right)_{2}$ Impoundment and dredging & $1,019,000$ \\
\hline$\left(V_{\text {tot }}\right)_{2 \mathrm{a}}$ Federal mining & $1,104,000$ \\
\hline$\left(V_{\text {tot }}\right)_{3 \mathrm{a}}$ Non-Federal mining, low estimate & $1,547,000$ \\
\hline$\left(V_{t o t}\right)_{3 b}$ Non-Federal mining, high estimate & $2,007,000$ \\
\hline
\end{tabular}

The volume of sediment deprived to downdrift beaches that the Federal government is responsible for, $V_{F e d}$, can be estimated by the following:

$$
V_{\text {Fed }}=V_{t o t}-V_{p}-V_{m N F}-V_{o}
$$

where $V_{p}$ is the volume of material placed on downdrift beaches, $V_{m N F}$ is the volume of material mined by non-Federal entities, and $V_{o}$ is the volume of material accumulated offshore. Due to the uncertainty surrounding the volume of material removed from the navigation channel by non-Federal entities, these volumes will be excluded from this analysis. The volume $\left(V_{t o t}\right)_{2 a}$ 
$(1,104,000 \mathrm{cu} y d)$, is similar to, and within the error of the net longshore transport estimate total $\left(V_{t o t}\right)_{1}$ for the era. This value includes estimated volumes of federally permitted mining and therefore will be considered the best estimate of total volume loss. Removal of a $V_{p}$ of $209,500 \mathrm{cu}$ yd, a $V_{m N F}$ of $243,000 \mathrm{cu}$ yd, and $V_{o}$ of $118,000 \mathrm{cu}$ yd from $\left(V_{t o t}\right)_{2 \mathrm{a}}$ gives a $V_{F e d}$ equal to $493,000 \mathrm{cu}$ yd $\left( \pm 216,000 \mathrm{cu}\right.$ yd), or 46 percent of the best estimate of total volume loss $\left(V_{t o t}\right)_{2 a}$. Uncertainty associated with federally permitted mining is unknown; therefore, it is not included in the potential error for the $V_{F e d}$ value.

\section{Summary}

The responsibility of the Federal government for erosion downdrift of the Federal navigation project at Mattituck Inlet was evaluated by explicit (measured) and implicit (potential transport) approaches. Shoreline change analysis provided an explicit evaluation of shoreline impacts, whereas the sediment budget analysis allowed for evaluation of the potential loss of sediment to downdrift beaches.

Long-term shoreline analysis showed that shoreline recession attributable to the inlet extends for approximately 9,600 ft to the east of the inlet. This 9,600 ft zone of influence was separated into primary and secondary erosion impact areas located adjacent to the inlet with the primary area having a higher rate of shoreline recession. A background shoreline recession rate was calculated at $1.0 \mathrm{ft} /$ year from regional shoreline position data. Residual shoreline change rates, or the change attributable to the inlet, were then determined by removing the background trend from the shoreline change rates. This subtraction resulted in a residual rates of $0.7 \mathrm{ft} /$ year $( \pm 0.4 \mathrm{ft} /$ year) for the primary erosion area and $0.3 \mathrm{ft} /$ year $( \pm 0.4 \mathrm{ft} /$ year $)$ for the secondary erosion area. The percent of shoreline recession attributable to the Federal navigation project was determined at 41 and 23 percent in the primary and secondary recession areas, respectively. A volume loss of 235,000 cu yd ( $\pm 91,000 \mathrm{cu}$ yd) was calculated for beaches within the identified impact areas, given a uniform recession of the profile over the depth of active transport.

Analysis by the implicit method indicates that the Federal navigation project at Mattituck Inlet resulted in a 94 percent reduction in average annual longshore sediment transport between 1906 and 1950, and a 58 percent reduction between 1950 and 2004. Total volume loss attributable to the Federal navigation project was estimated to be $1,063,000 \mathrm{cu}$ yd $( \pm 247,000 \mathrm{cu} \mathrm{yd})$. The volumes of material bypassed through placement of dredged material, documented non-Federal sand mining, and offshore losses were removed from the total volume loss. This adjustment resulted in an estimated sediment volume loss to downdrift beaches of 493,500 cu yd ( $\pm 250,000 \mathrm{cu} \mathrm{yd})$. This volume, as determined by the sediment budget or implicit method, is about 2.1 times greater than the volume determined through the shoreline change-explicit method. The implicit sediment budget method accounts for potential volume losses along all downdrift beaches and not just those in the impact erosion zone identified in the explicit method. 
In summary, construction and maintenance of the Federal navigation project at Mattituck Inlet, NY, was found to be responsible for 41 percent of shoreline recession for the 4,000 ft of shoreline directly downdrift of Mattituck Inlet. Federal responsibility decreased to 23 percent for the secondary area of impact, located 4,000 to 9,600 ft east of the inlet. The Federal navigation project decreased the average annual longshore sediment transport rate by 94 percent between 1906 and 1950, and 58 percent from 1950 through 2004. This reduction in the longshore sediment transport rate resulted in a total deficit of $493,000 \mathrm{cu}$ yd $( \pm 216,000 \mathrm{cu}$ yd) to beaches east (downdrift) of the inlet. 


\section{Mitigation Alternatives}

This Section 111 Continuing Authorities Program study identified three mitigation alternatives for Mattituck Inlet. Each alternative is evaluated by a sediment budget approach in this section.

\section{Alt 1: Beneficial Placement}

The beneficial placement alternative continues the existing practice of periodic channel maintenance dredging and downdrift placement. This alternative is discussed in Chapter 5. Present shoaling rates in the Mattituck navigation channel are insufficient to mitigate erosion in identified primary and secondary impact areas. Under this alternative, erosion in the primary area is mitigated; however, erosion continues within the secondary erosion area at a rate of approximately $4,000 \mathrm{cu}$ yd/year.

\section{Alt 2: Annual Bypassing}

This alternative would bypass volume of littoral material equivalent to the annual impoundment rate updrift of the west jetty at Mattituck Inlet. At present, the average annual rate of sediment impoundment is approximately $7,000 \mathrm{cu}$ yd/year. Combined with annualized rates of beneficial dredged material placement, the total would be equivalent to a placement of $9,000 \mathrm{cu} \mathrm{yd} /$ year Figure 61). This volume is equivalent to approximately 75 percent of the average annual eastward longshore transport rate.

The bypassed material, predominantly sand, would be mechanically removed from the subaerial impoundment fillet and bypassed to downdrift beaches by truck. Bypassed material would be stockpiled near the east jetty and spread along the beach within the primary erosion area. Figure 62 shows required areas of removal to supply this amount of sediment on an annual basis. Application of equilibrium shoreline concepts indicates that placement of 9,000 cu yd of material would advance the shoreline approximately $4.3 \mathrm{ft}$ within the primary erosion area. The actual advance of shoreline position would initially be less, as a portion of the placed material would be required to raise berm height. Profile readjustment and sediment dispersal would also reduce the actual shoreline advance. A time lag of years should be anticipated for stabilization of downdrift beaches to allow for natural migration of material. Monitoring of shoreline position could allow for reduced (or increased) volumes bypassed annually in an adaptive management plan. Alternatively, material could be bypassed every 
2 years or more to reduce mobilization and contracting costs. This longer interval would increase (or reduce) the area of removal shown in Figure 62.

The direct benefit of this alternative is elimination of the potential for barrier spit breaching adjacent to the east jetty. Also, an increase in sediment supply to downdrift beaches would create wider beaches, which, in turn, provide additional storm protection to the bluffs and protects private property. It is anticipated that sediment accumulation rates in the navigation channel and offshore shoal may be reduced. This alternative would not improve the present condition of the channel.

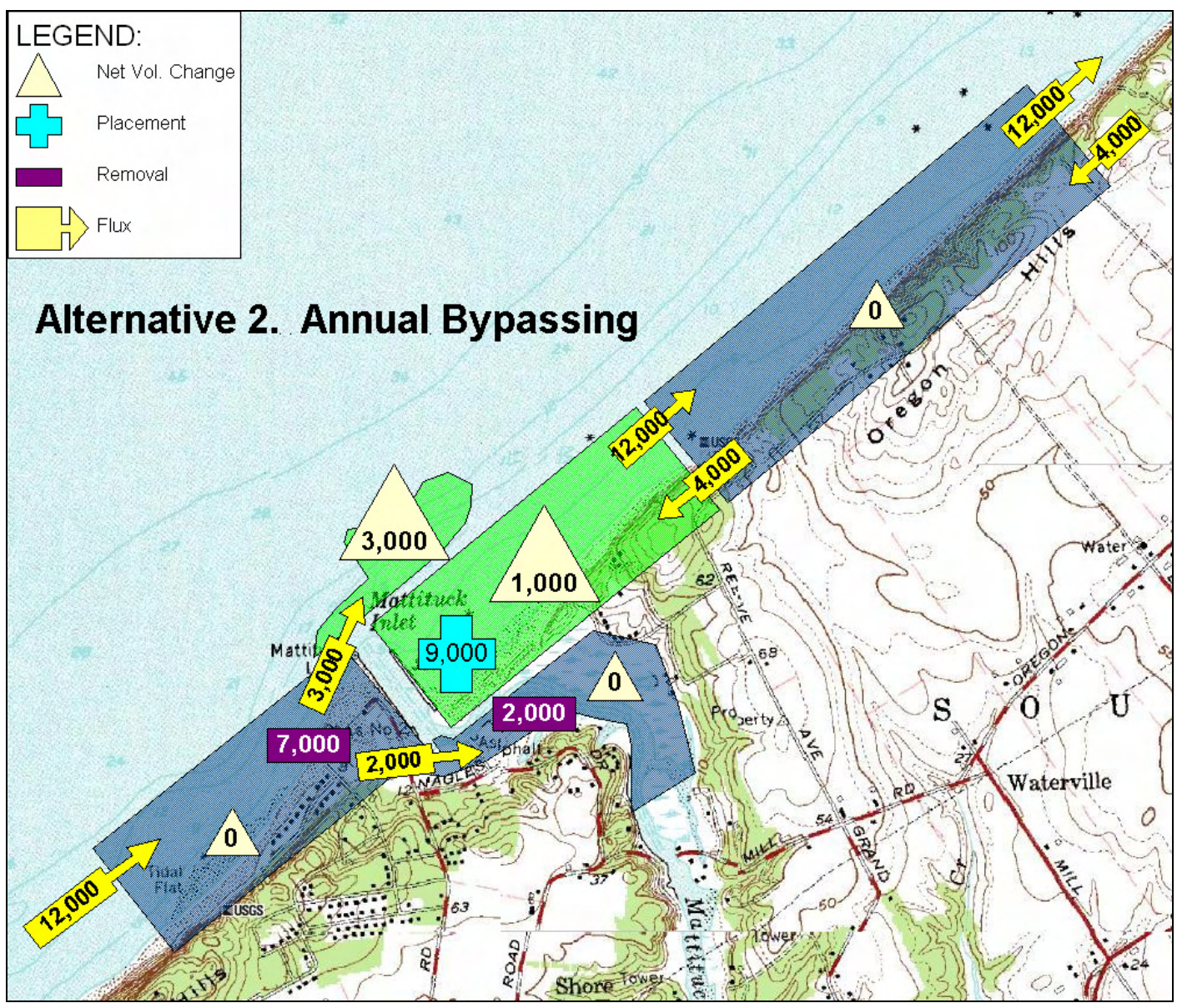

Figure 61. Alt 2, annual sand bypassing 


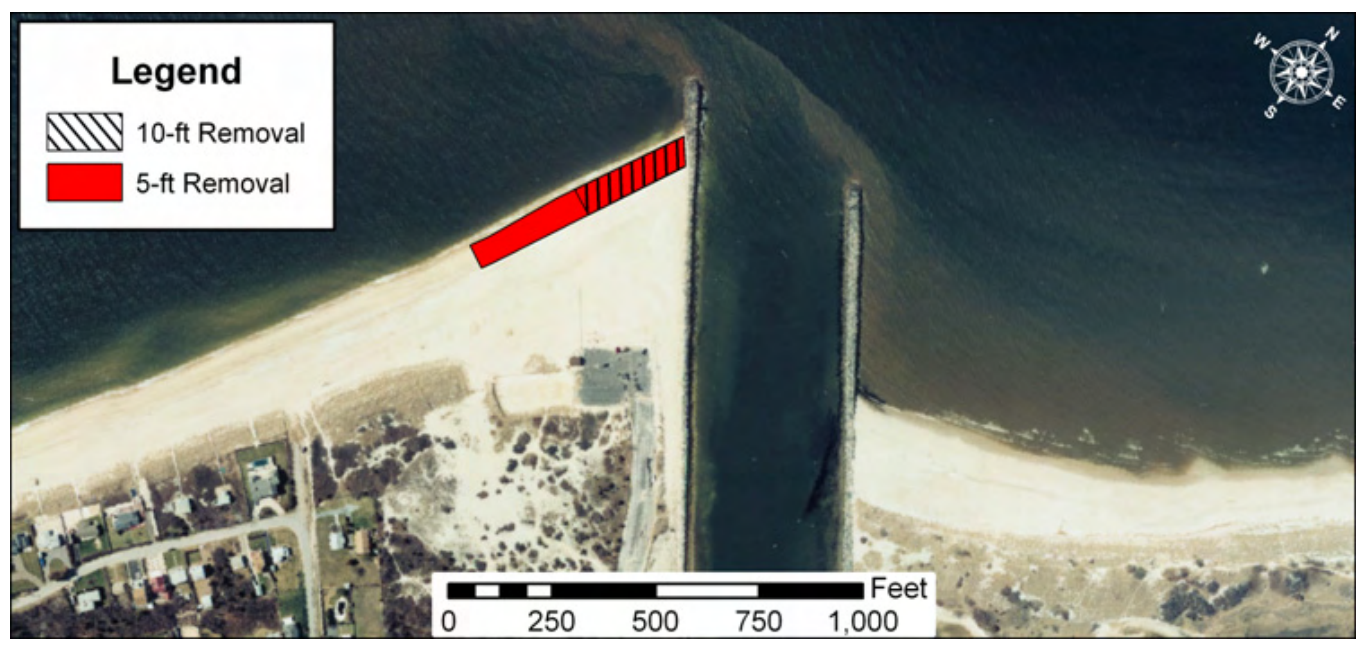

Figure 62. Areas of removal required to satisfy Alt 2 (7,000 cu yd/year)

\section{Alt 3: Advance Bypassing}

This alternative proposes removal of a portion of the accretion fillet and subaerial portions of the north and south flood shoals (Figure 63), combined with channel improvements on an 8- to 10-year basis. Since construction of the west jetty in 1906 and its seaward extension in 1938, an estimated 408,000 to 473,000 cu yd of material has accumulated updrift of the structure. Material removed from these areas would be transported to reinforce the dune field adjacent to the east jetty and nourish the beach in the primary and secondary erosion areas directly downdrift of the inlet.

Assuming an approximate 10- $\mathrm{ft}$ thickness of material is removed from the fillet, north flood shoal, and south flood shoal, volume in each borrow area is estimated at 91,000,17,000, and 17,000 cu yd of material, respectively.

Estimates of the flood shoal volumes were limited to the subaerial portions of the sand bodies. It is likely that a greater amount of beach-quality material is present. The proposed fillet removal area in Figure 63 retains a $90-\mathrm{ft}$-wide beach fronting the park and the vegetation line. If distributed evenly throughout the primary and secondary erosion areas, this alternative would produce a $25-\mathrm{ft}$ advance of the shoreline. Average annual longshore transport rates in the vicinity of Mattituck Inlet (12,000 cu yd/year) would support this magnitude of removal from the accretion fillet $(91,000 \mathrm{cu}$ yd) on an 8-year interval. Shoals within the inlet channel would take a longer time to reform, because mining of material from the fillet will reduce transport around the west jetty into the channel. The volume of bypassed material could be augmented if operations coincide with channel maintenance. The volume of material bypassed by this activity would be equivalent to the estimated average annual eastward longshore transport rate.

Benefits from this alternative are improvement of the downdrift beach, increased sediment supply to beaches east of the study area, and decreased maintenance of the navigation channel. Wider downdrift beaches would provide storm protection for bluffs, eliminate the potential for breaching adjacent to the east jetty, and protect private property and bulkheads. Increased storm protection 
would reduce, and/or avoid costs associated with local rebuilding and land loss. Removal of the large portion of the accretion fillet would significantly reduce transport rates along sediment pathways to the offshore shoal complex and into the navigation channel. Circulation modeling results in Chapter 3 demonstrate that removal of the flood shoal would enhance circulation in Mattituck Creek. Removal of this sediment would also improve the present condition, navigability of the channel, and increase the time between required maintenance dredgings.

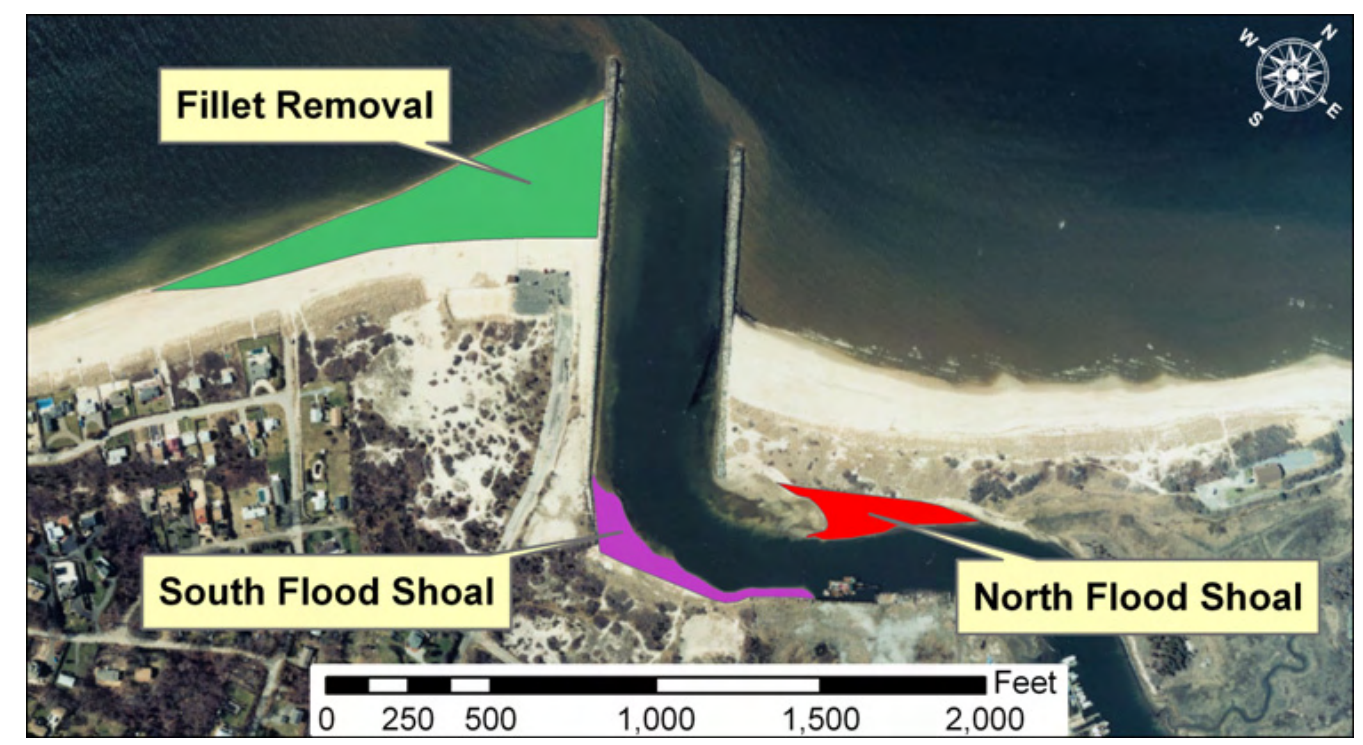

Figure 63. Proposed borrow areas for Alt 3

\section{Summary}

Three alternatives were evaluated for mitigating shore erosion downdrift of Mattituck Inlet, NY. The first alternative continues the present practice of beneficial placement of dredged material on downdrift beaches. This alternative effectively mitigates shore erosion only in the primary erosion area. The second alternative involves annual bypassing of material impounded updrift of the west jetty to downdrift beaches. This activity would increase bypassing rates to an estimated 75 percent of the average annual eastward longshore transport rate. Benefits of this alternative include stabilization of the primary and secondary erosion areas, increased storm protection through wider beaches, and elimination of potential spit breaching adjacent to the inlet. This alternative improves on existing practice and does not mitigate past damages to the downdrift shorelines.

The third alternative provides for advance bypassing of material accumulated in the impoundment fillet, in addition to removal of portions of the flood shoal. An estimated volume of $125,000 \mathrm{cu}$ yd of material is available from these borrow areas for placement on downdrift beaches. The primary benefit of this alternative is increased storm protection along downdrift beaches, eliminating additional land losses and rebuilding costs associated with the Federal navigation project. Additional benefits include reduction of shoaling rates in the navigation channel, improvement of channel functioning, and enhanced circulation in Mattituck Creek. 


\section{References}

Allee, King, Rosen, and Fleming, Inc. (1995). "Town of Southold erosion management plan," prepared for the Town of Southold, NY, and the New York State Department of State, Division of Coastal Resources, Albany, NY, variously paginated.

Anders, F. J., and Byrnes, M. R. (1991). "Accuracy of shoreline change rates as determined from maps and aerial photographs," Shore and Beach 59(1), 1726.

Bartholomew, F. L., and McGuinness, Jr., W. V. (1972). "Coast stabilization and protection on Long Island," prepared by the Center for the Environment and Man, Inc., for the Regional Marine Resources Council, Nassau-Suffolk Regional Planning Board, Hauppauge, NY, 47 pp.

Bokuniewicz, H. J., and Gordon, R. B. (1980). "Sediment transport and deposition in Long Island Sound," Advances in Geophysics 22, 69-106.

Chute, N. E. (1946). "Shoreline changes caused by hurricane of September 1944," Bulletin 9, Massachusetts Department of Public Works in cooperation with the U.S. Geological Survey, 47 pp.

Crowell, M., Leatherman, S. P., and Buckley, M. K. (1991). "Historical shoreline change: Error analysis and mapping accuracy," Journal of Coastal Research 7(3), 839-852.

Davies, D. (1972). "Stability of the north shore, Long Island, New York," M.S. thesis, State University of New York at Stony Brook, Stony Brook, NY, $92 \mathrm{pp}$.

Davies, D., Axelrod, E. W., and Connor, J. S. (1973). "Erosion of the north shore of Long Island," Marine Sciences Research Center, SUNY Stony Brook, Stony Brook, NY, Technical Report Series No.18, 101 pp.

Dean, R. G. (1973). "Heuristic models of sand transport in the surf zone," Proceedings of Conference on Engineering Dynamics in the Surf Zone, Institution of Engineers, Australia, 208-214.

Dolan, R., Fenster, M. S., and Holme, S. J. (1991). "Temporal analysis of shoreline recession and accretion," Journal of Coastal Research 7(3), 723744 .

Douglas, B. C., Crowell, M., and Leatherman, S. P. (1998). "Considerations for shoreline position prediction," Journal of Coastal Research 14(3),

1,025-1,033. 
Fields, L., Bosma, K. A., and Byrnes, M. R. (1999). "Historical shoreline change analysis: Western town line to Horton Point, Southhold, New York," Aubrey Consulting, Inc, Falmouth, MA, final report prepared for the Town of Southhold, NY, 92 pp. plus appendices.

Foster, E. R., and Savage, R. J. (1989). "Methods of historical shoreline analysis," Proceedings of Coastal Zone 1989, ASCE, 4,434 - 4,448.

Fuller, M. L. (1914). "The geology of Long Island, New York," Department of the Interior, U.S. Geological Survey, Professional Paper 82, 231 pp.

Graham, D., Sault, M., and Baily, J. (2003). "National Ocean Service shoreline - past, present, and future," Journal of Coastal Research SI(38), 14-32.

Hoeke, R. K., Zarillo, G. A., and Synder, M. (2001). "A GIS based tool for extracting shoreline positions from aerial imagery (BeachTools)," Coastal and Hydraulics Engineering Technical Note CHETN IV-37, U.S. Army Engineer Research and Development Center, Vicksburg, MS, 12 pp.

Hsu, J. R. C., and Evans, C. (1989). "Parabolic bay shapes and applications," Proceedings of the Institution of Civil Engineers 87 (2), 557-570.

Kraus, N. C., and Larson, M. (2003). "Analytical model of navigation channel infilling by cross-channel transport," Proceedings 28th Coastal Engineering Conference, World Scientific Press, Singapore, 3,698-3,710.

Kraus, N. C., Larson, M., and Kriebel, D. L. (1991). "Evaluation of beach erosion and accretion predictors," Proceedings of Coastal Sediments 1991, ASCE, 572-587.

Kraus, N. C., and Mason, J. G. (1991). "Field data set for testing beach erosion and accretion predictive criteria," Memorandum for Record, Coastal Engineering Research Center, U.S. Army Engineer Waterways Experiment Station, Vicksburg, MS.

Kraus, N. C., Larson, M., and Wise, R. A. (1999). "Depth of closure in beachfill design," Proceeding 12th National Conference on Beach Preservation Technology, FSBPA, Tallahasse, FL, 271-286.

Kraus, N. C., and Rosati, J. D. (1997). "Interpretation of shoreline-position data for coastal engineering analysis," Coastal Engineering Technical Note CETN II-39, U.S. Army Engineer Research and Development Center, Vicksburg, MS, $16 \mathrm{pp}$.

Krumbein, W. C. (1944). "Shore processes and beach characteristics," Beach Erosion Board, Technical Memorandum No. 3, U.S. Army Corps of Engineers, Washington, DC.

Leatherman, S. P. (2003). "Shoreline change mapping and management along the U.S. East Coast," Journal of Coastal Research SI(38), 5-13.

Leatherman, S. P., Dean, R. G., Kana, T., and Anders, F. J. (1997). "Goldsmith Inlet and adjacent areas, North Shore of Long Island, New York: Erosion problems and suggested modifications," Shore and Beach 65(3), 13-16. 
Luettich, R. A., Westerink, J. J., and Scheffner, N. W. (1992). “ADCIRC: An advanced three-dimensional circulation model for shelves, coasts, and estuaries, Report 1, theory and methodology and ADCIRC-2DDI and ADCIRC-3DL," Technical Report DRP-92-6, US Army Engineer Waterways Experiment Station, Vicksburg, MS.

Militello, A., Reed, C. W., Zundel, A. K., and Kraus, N. C. (2004). "Twodimensional depth-averaged circulation model M2D: Version 2.0; Report 1, technical documentation and user's guide," Coastal and Hydraulics Laboratory Technical Report ERDC/CHL TR-04-2, U.S. Army Research and Development Center, Vicksburg, MS.

Morgan, M. J., Kraus, N. C., and McDonald, J. (2005). "Geomorphic analysis of Mattituck Inlet and Goldsmith Inlet, Long Island, New York," Coastal and Hydraulics Laboratory Technical Report ERDC/CHL TR-05-2, U.S. Army Engineer Research and Development Center, Vicksburg, MS.

National Geodetic Survey. (1885). "Digital vector shoreline, north shore of Long Island," Source T-Sheet T01726, 1885, National Geodetic Survey, National Oceanographic and Atmospheric Administration Shoreline Data Explorer, http://www.ngs.noaa.gov/RSD/shoredata/NGS_Shoreline_ Products.htm.

National Geodetic Survey. (1994). "VERTCON 2.0," National Geodetic Survey, National Oceanographic and Atmospheric Administration, http://www.ngs.noaa.gov/TOOLS/Vertcon/vertcon.html.

National Oceanographic and Atmospheric Administration. (2000). "Tide and current glossary," U.S. Department of Commerce, National Oceanic and Atmospheric Administration, National Ocean Service, Center for Operational Oceanographic Products and Services, Silver Spring, MD, 29 pp.

National Ocean Service. (1969). "Basic hydrographic survey, Long Island Sound, Duck Pond Point to Herod Point Shoal," NGDC number HYD9303081023, Survey 4HO9087," U.S. Department of Commerce, National Oceanic and Atmospheric Administration, National Ocean Survey, Silver Spring, MD.

National Ocean Service. (2002). "Tide tables 2003, high and low water predictions, East Coast of North and South America, including Greenland," National Ocean Service, National Oceanographic and Atmospheric Administration, Silver Spring, MD.

New England River Basins Commission. (1975). "People and the Sound, erosion and sedimentation," planning report prepared for the New England River Basins Commission, New Haven, CT, Vol. 10, 64 pp. plus appendices.

New York State GIS Clearinghouse. (2001). "New York State statewide digital orthoimagery program," http://www.nysgis.state.ny.us/orthoprogram.htm.

Omholt, T. (1974). "Effects of small groins on shoreline changes on the north shore of Suffolk County, New York," New York Ocean Science Laboratory Technical Report No. 0028, Montauk, NY, 47 pp. 
Ralston, R. R. (1929). "Report on survey of Mattituck Harbor, NY," in House of Representatives (1935) report from the Chief of Engineers on preliminary examination and survey of Mattituck Harbor, NY, House Document No. 8, $71^{\text {st }}$ Congress, $1^{\text {st }}$ Session, U.S. Government Printing Office, Washington, DC.

Rosati, J. D., and Kraus, N. C. (1999a). "Formulation of sediment budgets at inlets," Coastal Engineering Technical Note CETN-IV-15, U.S. Army Engineer Research and Development Center, Vicksburg, MS, 20 pp.

Rosati, J. D., and Kraus, N. C. (1999b). "Sediment Budget Analysis System (SBAS)," Coastal Engineering Technical Note CETN-IV-20, U.S. Army Engineer Research and Development Center, Vicksburg, MS, 14 pp.

Schubel, J. R. (1976). "An assessment of the effects of the periodic removal of sand from the western jetty at Mattituck Inlet on shore erosion of contiguous shoreline segments," report prepared for the Mattituck Park District, Marine Sciences Research Center, State University of New York at Stony Brook, Stony Brook, NY.

Shalowitz, A. L. (1964). Shore and sea boundaries. (Two vols.), Volume Two: Interpretation and Use of Coast and Geodetic Survey Data, Publication 10-1, U.S. Department of Commerce, Coast and Geodetic Survey, Washington, DC., 749 pp.

Silvester, R. (1970). "Growth of crenulate shaped bays to equilibrium," Journal of Waterways and Harbors Division 96 (2), 275-287.

Smith, E. R. (1988). "Case histories of Corps breakwater and jetty structures, Report 5, North Atlantic Division,” Technical Report REMR-CO-3, U.S. Army Engineer Research and Development Center, Vicksburg, MS.

Smith, J. M., Sherlock, A. R., and Resio, D. T. (2001). "STWAVE: Steadystate spectral wave model user's manual for STWAVE Version 3.0," Coastal and Hydraulics Laboratory Special Report ERDC/CHL SR-01-1, U.S. Army Engineer Research and Development Center, Vicksburg, MS.

Taney, N. E. (1961). "Geomorphology of the south shore of Long Island, New York," U.S. Army Corps of Engineers, Beach Erosion Board, Technical Memorandum No. 128, 67 pp.

Tanski, J. J. (1981). "Episodic bluff erosion on the north shore of Long Island, New York," M.S. thesis, Marine Sciences Research Center, State University of New York at Stony Brook, Stony Brook, NY.

Tetra Tech, Inc. (1979). "Jamesport nuclear project shoreline study," Jacksonville, FL, 78 pp.

Thieler, E. R., and Danforth, W. W. (1994). "Historical shoreline mapping (I): Improving techniques and reducing positioning errors," Journal of Coastal Research 10(3), 549-563.

U.S. Army Corps of Engineers. (1971). "National shoreline study, regional inventory report, North Atlantic Region," U.S. Army Engineer Division, North Atlantic, Brooklyn, NY, Vols. I and II. 
U.S. Army Engineer District, New York. (1969). "North shore of Long Island, Suffolk County, New York, beach erosion control and interim hurricane study," U.S. Army Engineer District, NY, 74 pp. plus appendices.

Watanabe, A. (1987). "3-dimensional numerical model of beach evolution," Proceedings Coastal Sediments '87, ASCE, 802-817.

Wise, W. M., Sanko, P., and Schubel, J. R. (1978). "Erosion and erosion control on the north shore of Long Island," Workshop on Erosion in Bays, Sounds, and Estuaries, Sea Grant Marine Advisory Services, Stony Brook, NY, 22 pp.

Yasso, W. E. (1965). "Plan geometry of headland-bay beaches," Journal of Geology 73, 702-714. 


\section{Appendix A Shoreline Change Rate Graphs}

This appendix contains plots of shoreline position and shoreline change rate for each interval investigated in this study. The upper panel of each figure plots the position of each shoreline (relative to the baseline), and the bottom panel plots the shoreline change rate and rms error.

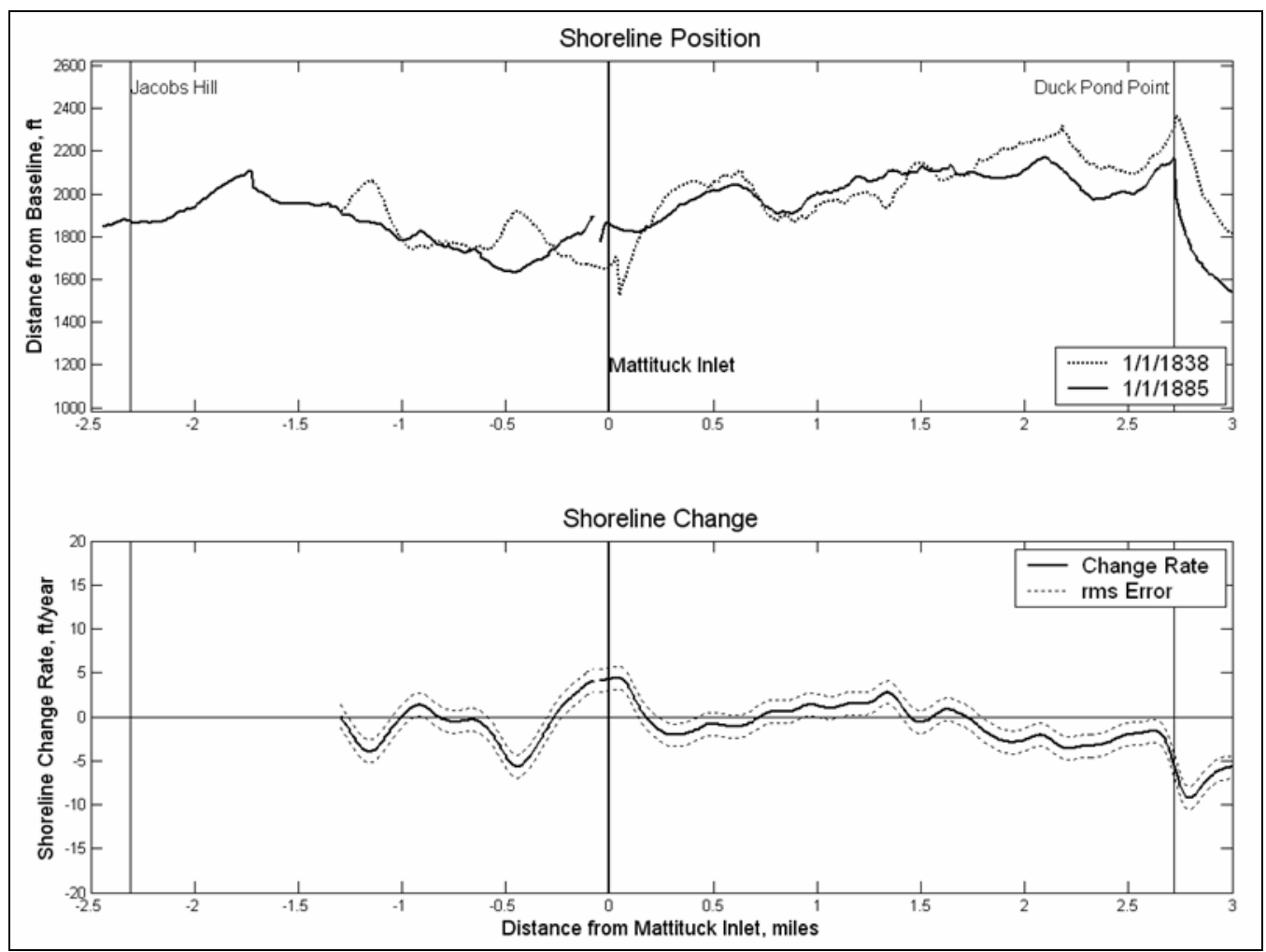

Figure A1. Shoreline change, 1838 to 1885 


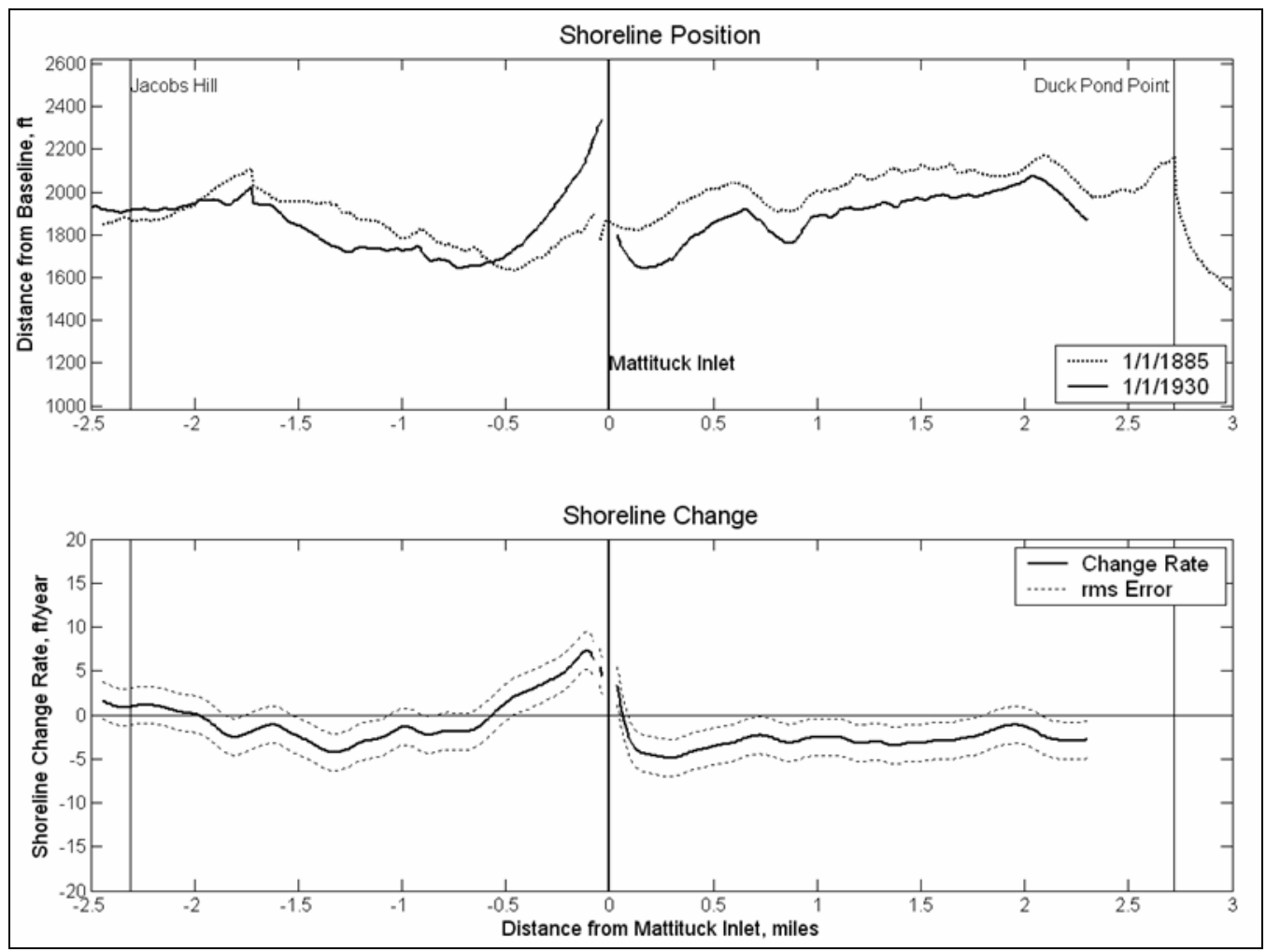

Figure A2. Shoreline change, 1885 to 1930

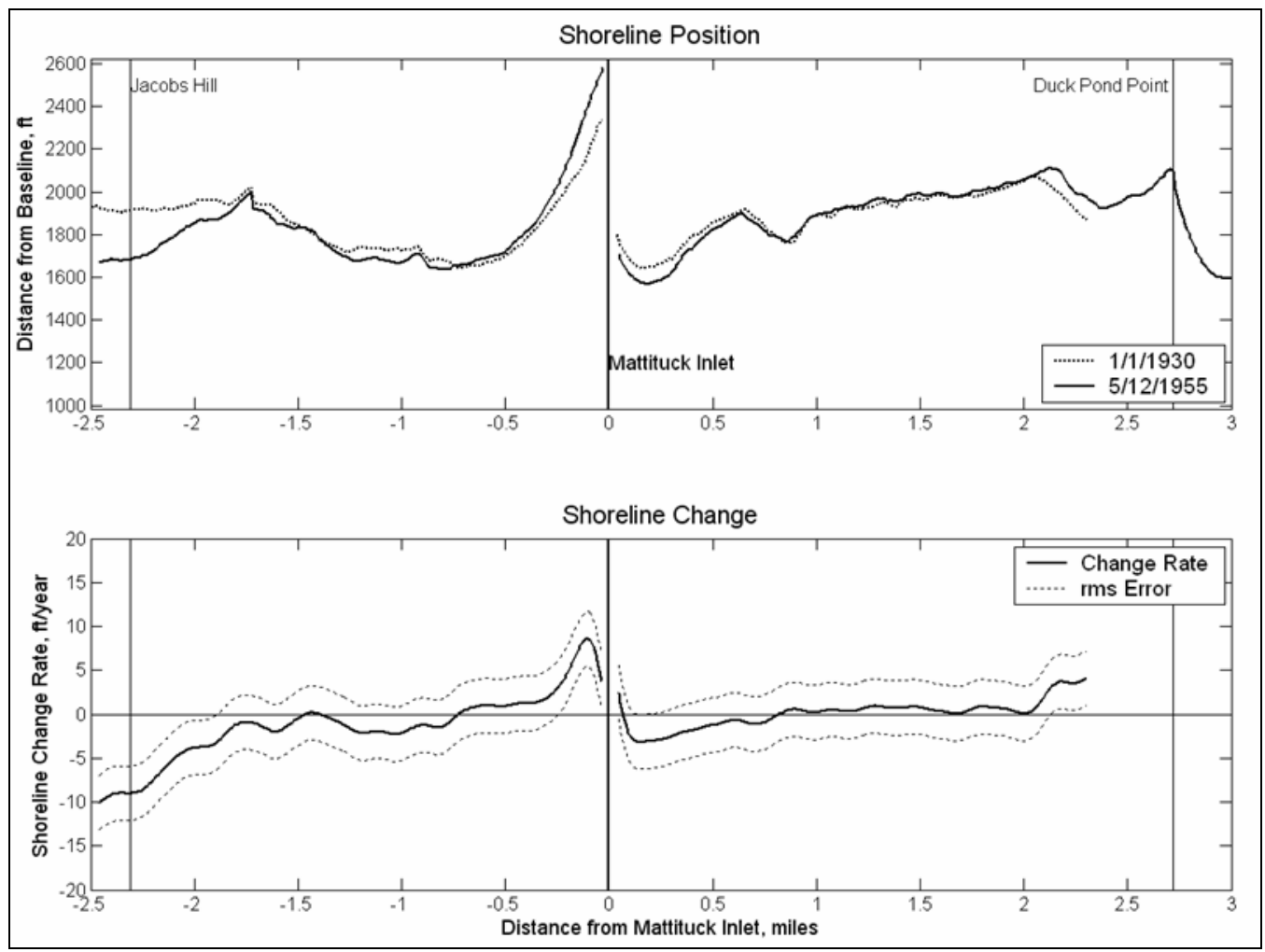

Figure A3. Shoreline change, 1930 to 1955 


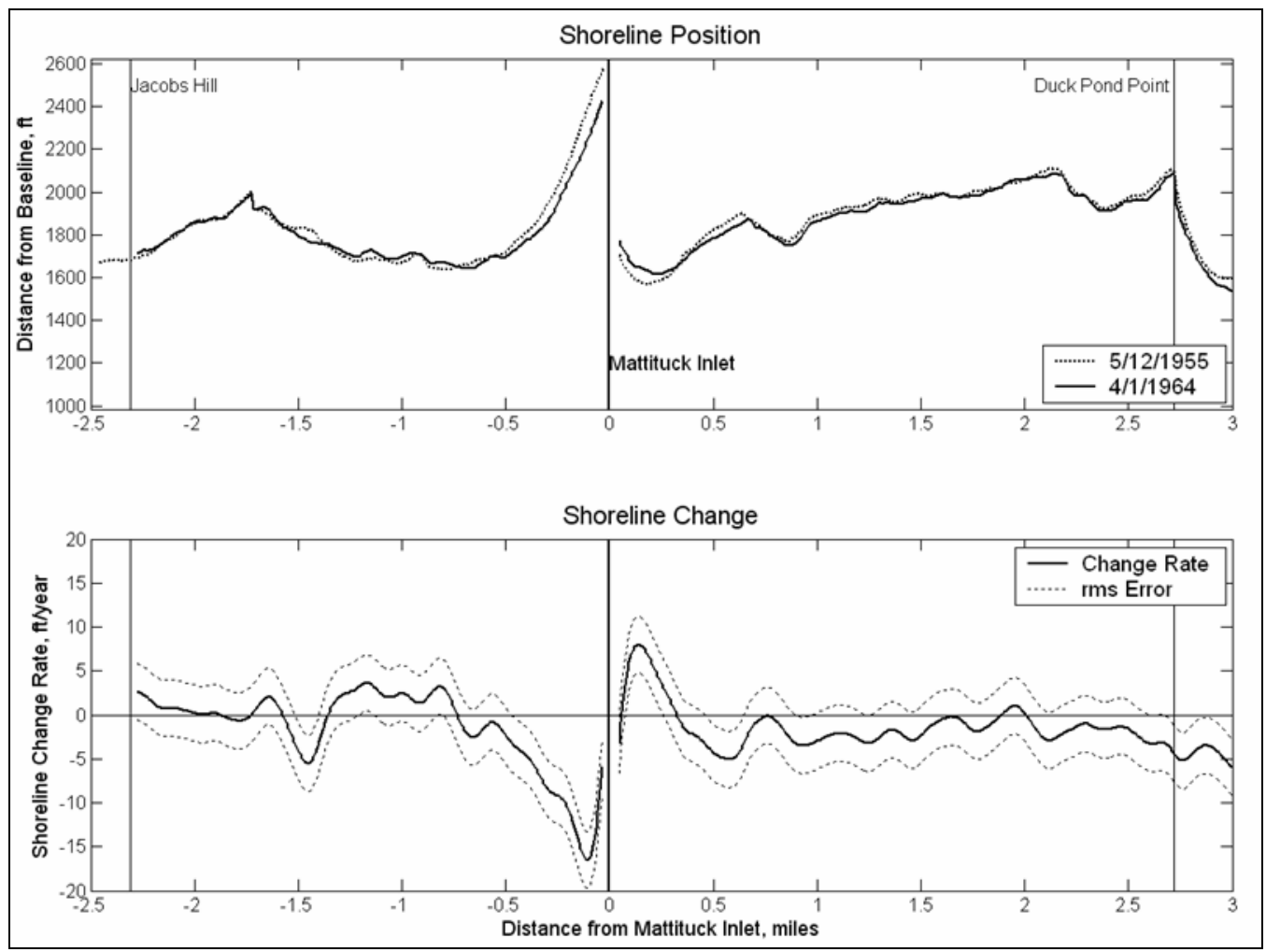

Figure A4. Shoreline change, 1955 to 1964

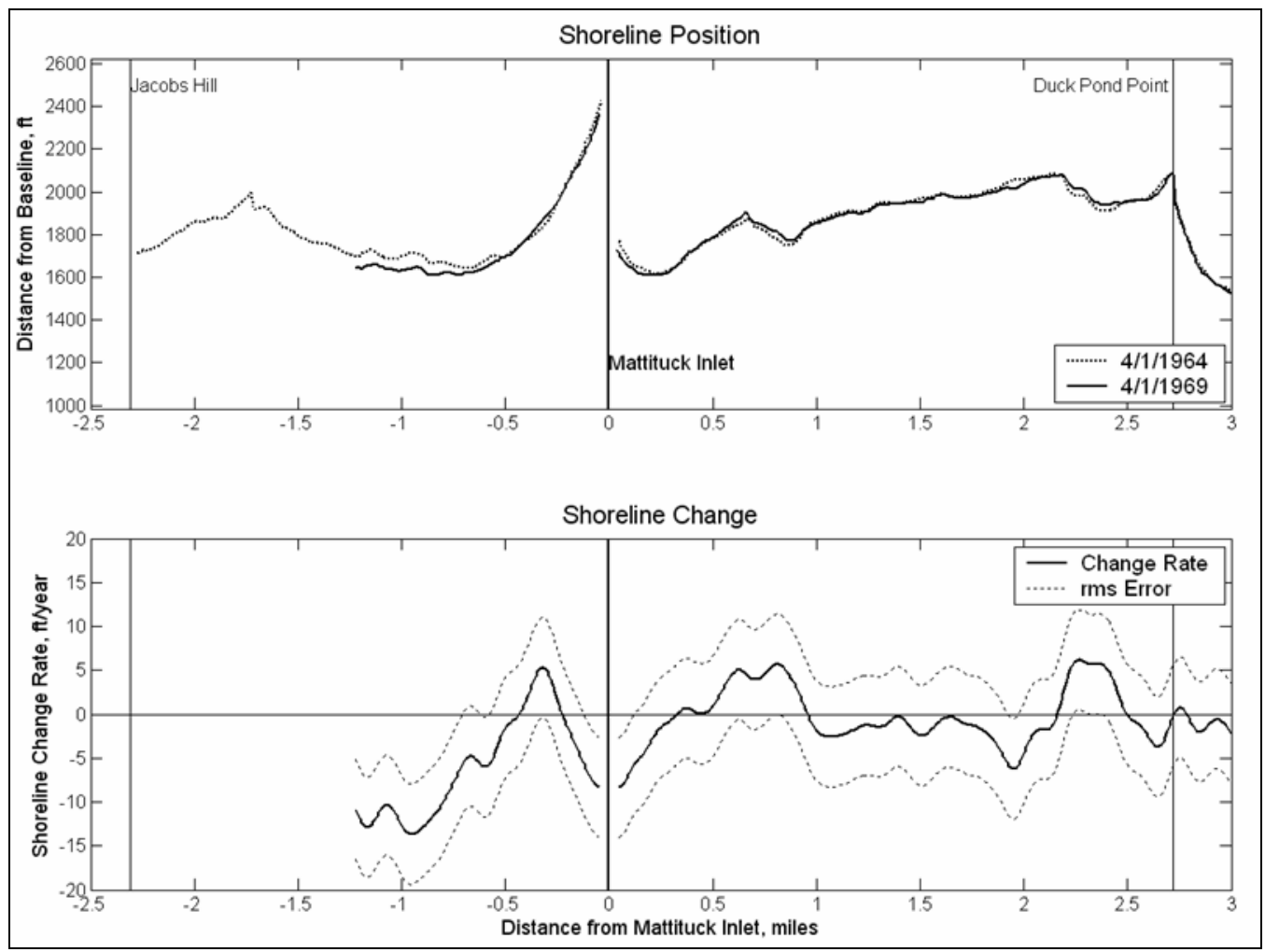

Figure A5. Shoreline change, 1964 to 1969 


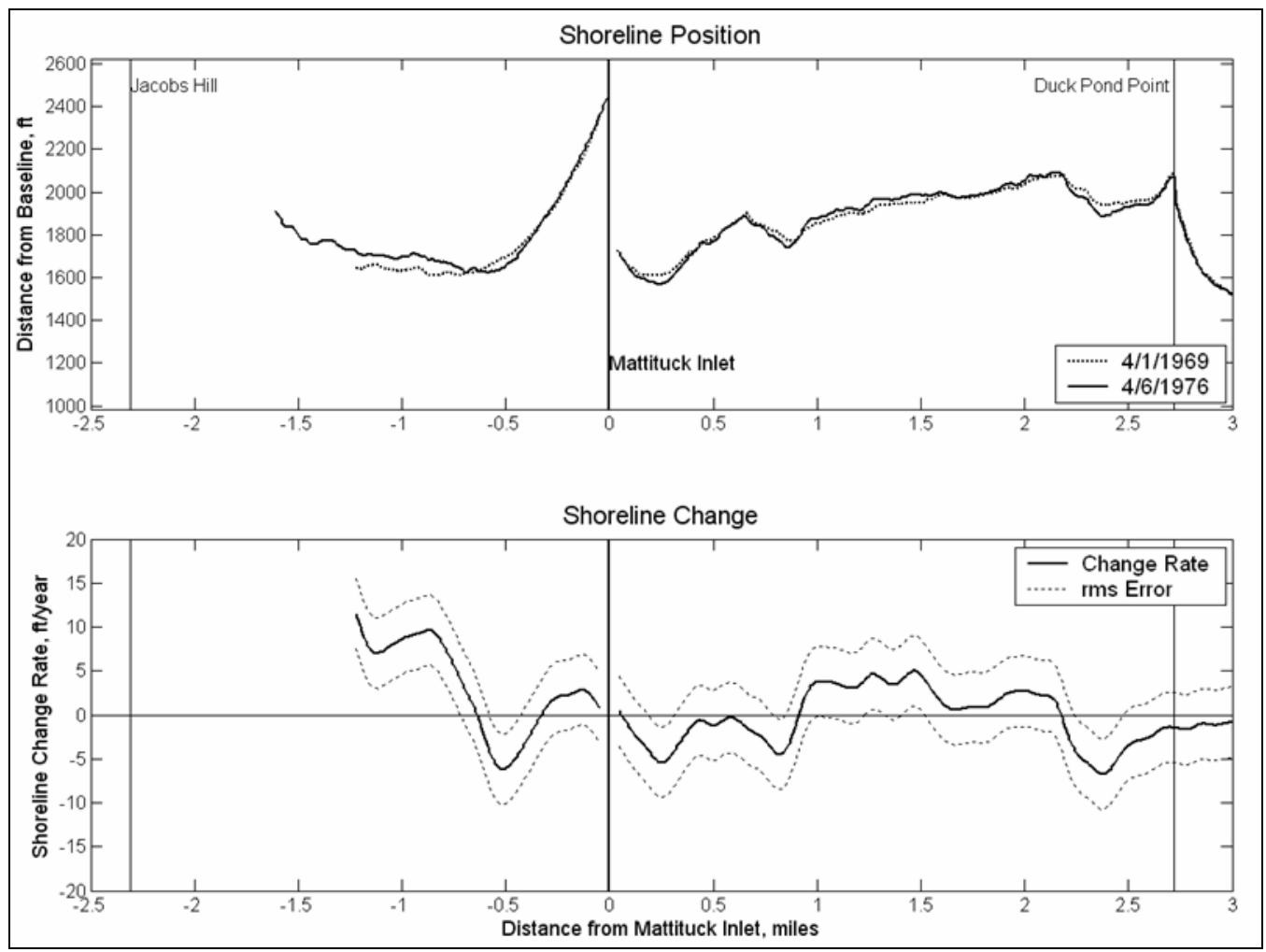

Figure A6. Shoreline change, 1969 to 1976

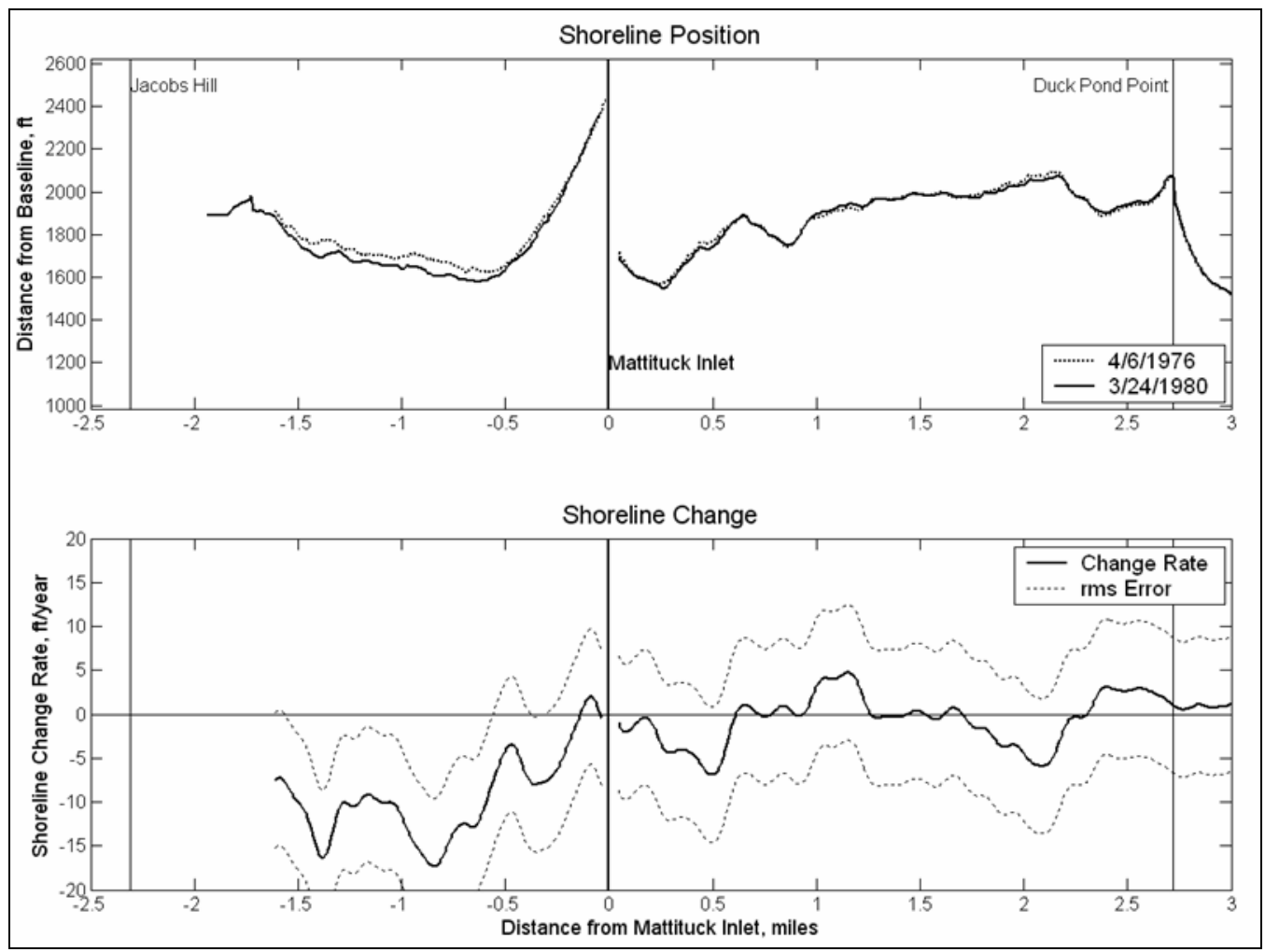

Figure A7. Shoreline change, 1976 to 1980 


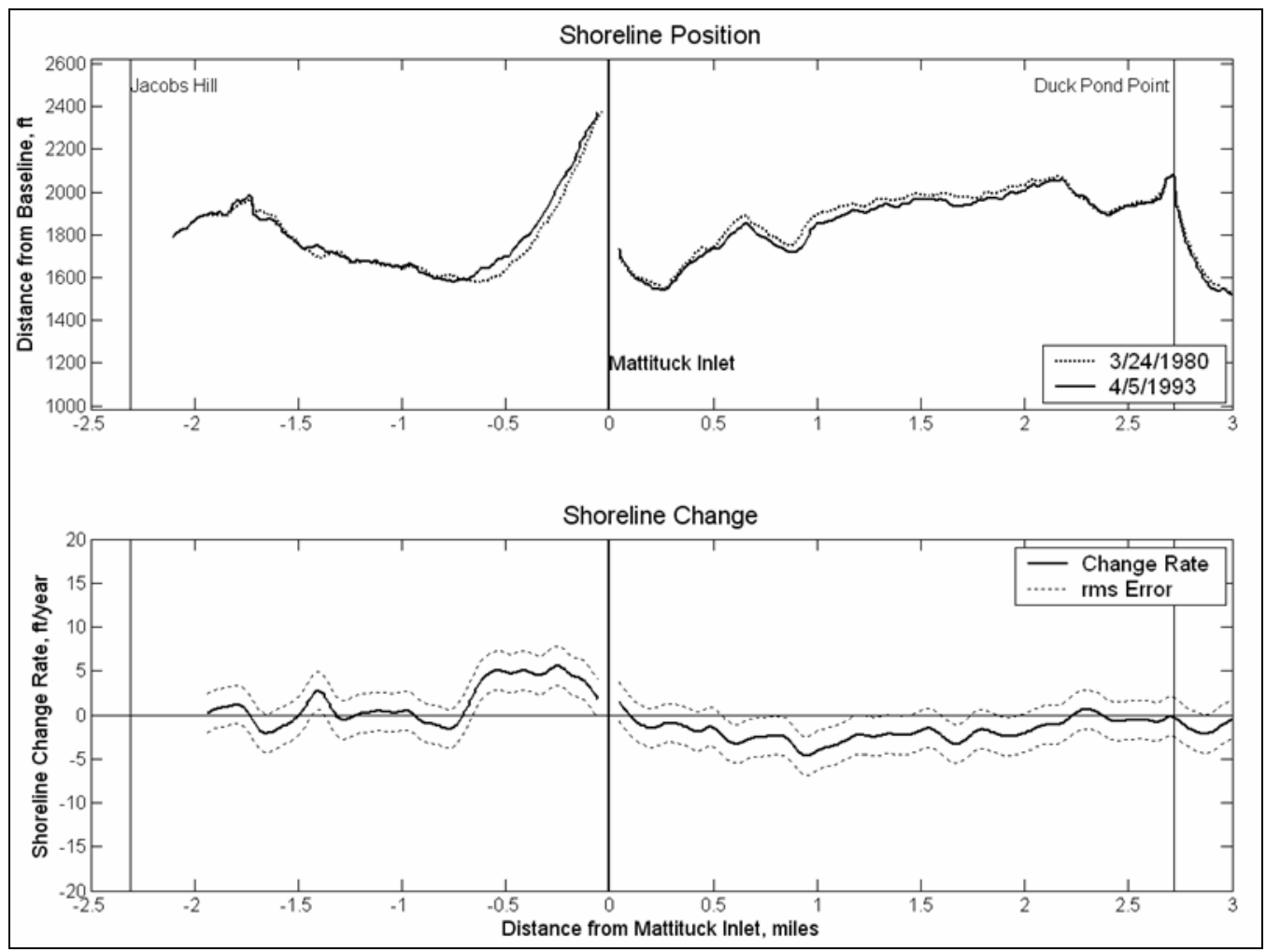

Figure A8. Shoreline change, 1980 to 1993

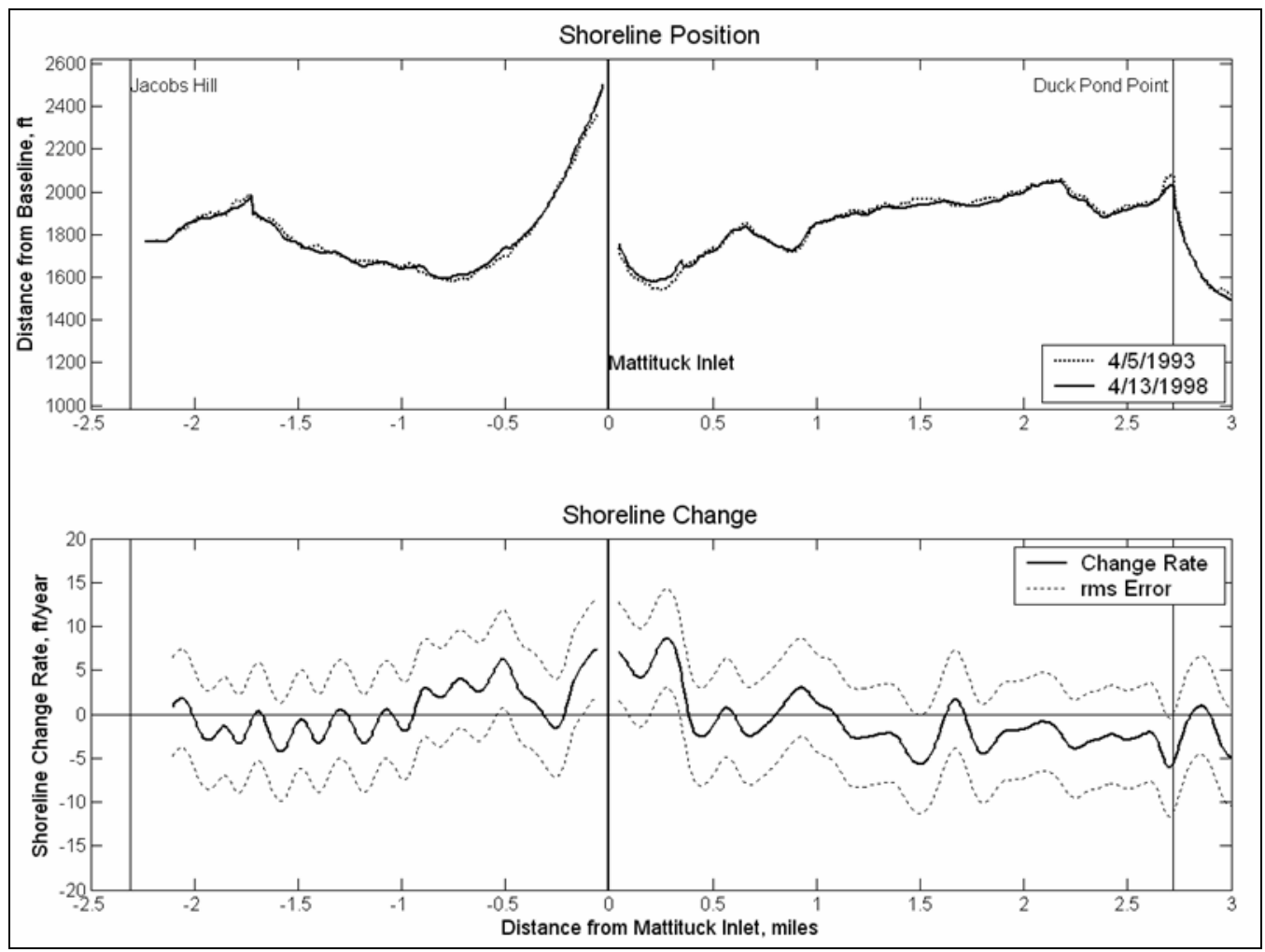

Figure A9. Shoreline change, 1993 to 1998 


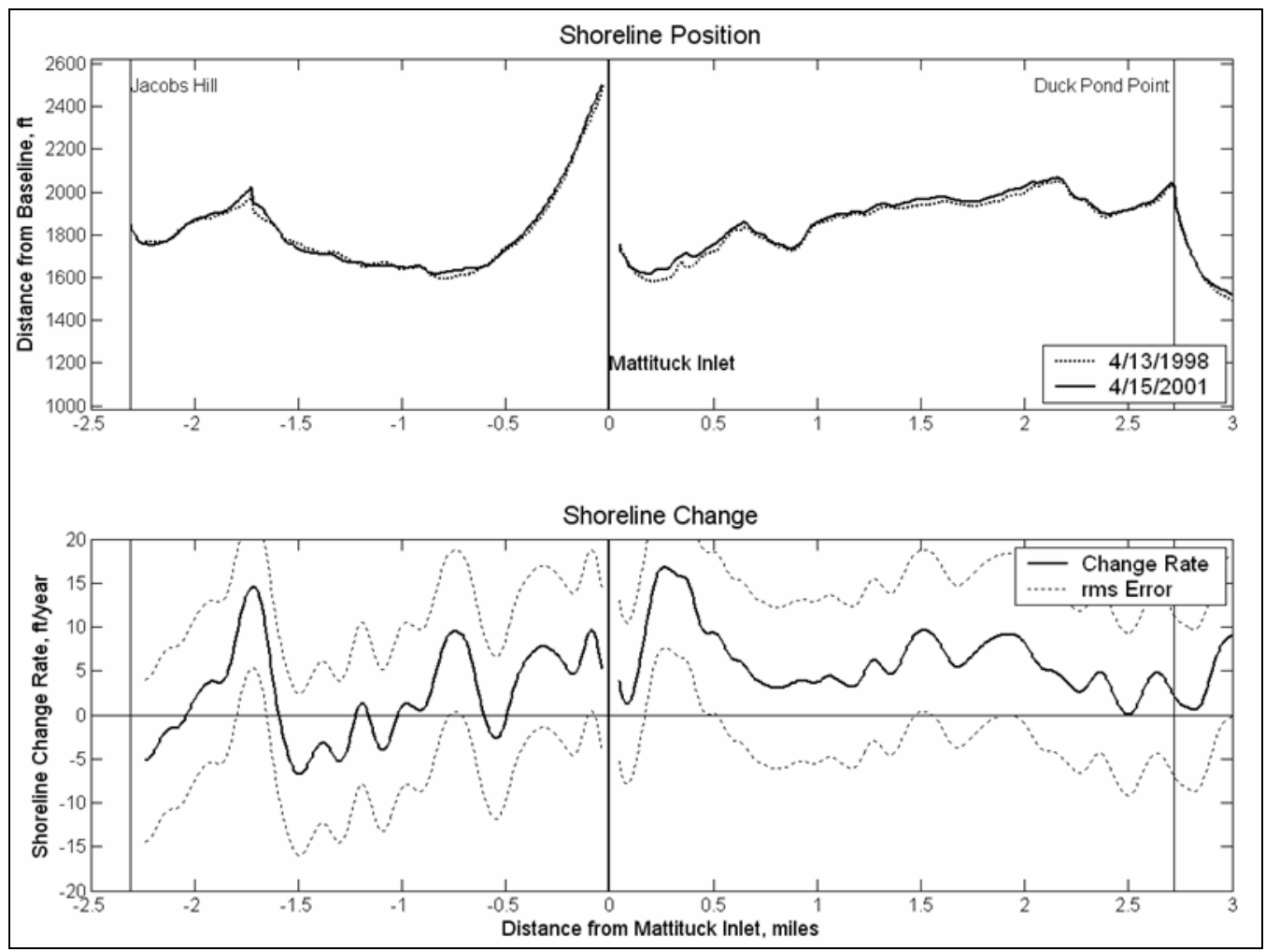

Figure A10. Shoreline change, 1998 to 2001

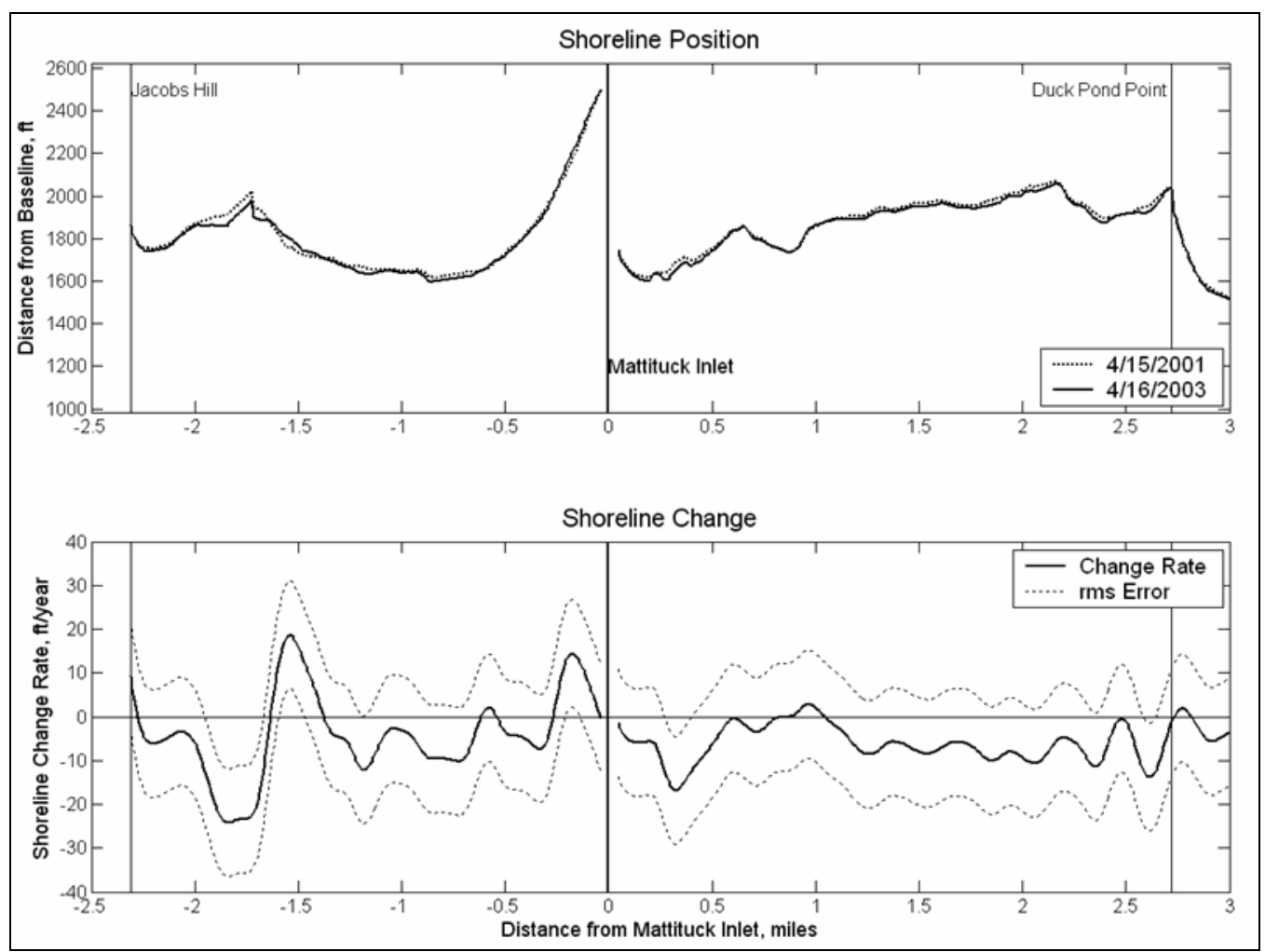

Figure A11. Shoreline change, 2001 to 2003, note change in shoreline change rate axis scale (due to short time interval) 


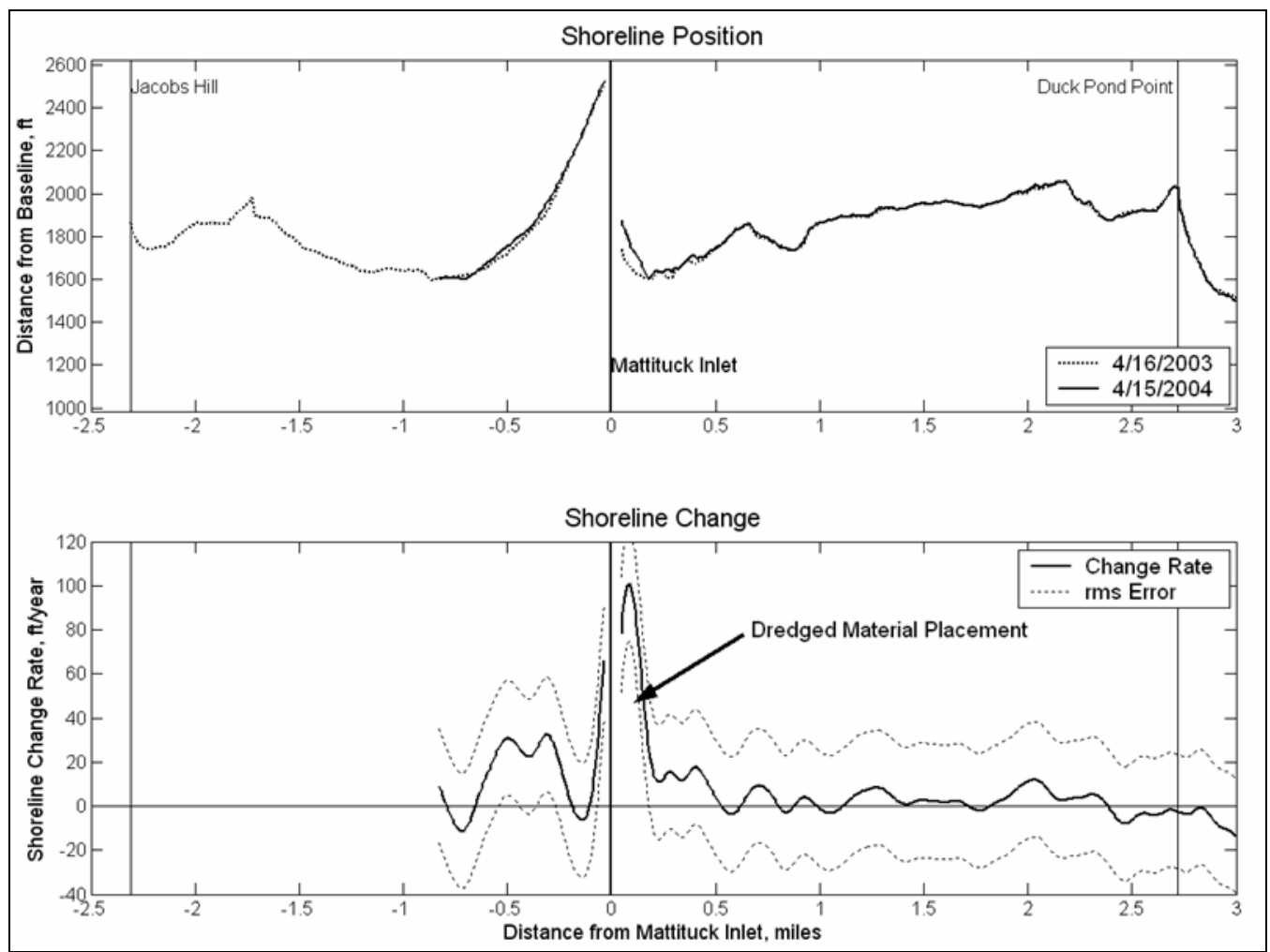

Figure A12. Shoreline change, 2003 to 2004, note change in shoreline change rate axis scale (due to short interval) 


\section{Appendix B Local Shoreline Change Rates by Interval}

\begin{tabular}{|c|c|c|c|c|c|}
\hline \multicolumn{6}{|c|}{$\begin{array}{l}\text { Table B1 } \\
\text { Local Shoreline Change Rates by Interval, ft/year }\end{array}$} \\
\hline Interval & Time, year & Local Area & Updrift Reach & Downdrift Reach & Error \\
\hline 1885-1930 & 45 & -2.1 & 2.9 & -3.5 & 1.3 \\
\hline 1930-1955 & 25 & -0.9 & 2.9 & -1.8 & 2.1 \\
\hline $1955-1964$ & 9 & -0.8 & -7.1 & 0.3 & 3.2 \\
\hline 1964-1969 & 5 & -2.6 & -1.8 & 0.1 & 5.7 \\
\hline 1969-1976 & 7 & 1.9 & -0.7 & -2.2 & 4.0 \\
\hline 1976-1980 & 4 & -3.6 & -5.5 & -2.7 & 7.7 \\
\hline 1980-1993 & 13 & -1.2 & 4.2 & -1.6 & 2.2 \\
\hline 1993-1998 & 5 & -1.4 & 3.1 & 1.9 & 5.6 \\
\hline 1998-2001 & 3 & 3.4 & 5.1 & 8.6 & 8.2 \\
\hline 2001-2003 & 2 & -5.8 & 0.5 & -6.7 & 11.2 \\
\hline 2003-2004 & 1 & 1.2 & 15.6 & 22.9 & 24.0 \\
\hline
\end{tabular}


Table B2

Local Net Shoreline Change by Interval, ft

\begin{tabular}{||c|c|c|c|c|c||}
\hline \hline Interval & Time, year & Local Area & Updrift Reach & Downdrift Reach & Error \\
\hline \hline $1885-1930$ & 45 & -95 & 131 & -158 & 59 \\
\hline $1930-1955$ & 25 & -23 & 74 & -46 & 53 \\
\hline $1955-1964$ & 9 & -7 & -63 & 3 & 28 \\
\hline $1964-1969$ & 5 & -13 & -9 & 1 & 29 \\
\hline $1969-1976$ & 7 & 13 & -5 & -15 & 28 \\
\hline $1976-1980$ & 4 & -14 & -22 & -11 & 31 \\
\hline $1980-1993$ & 13 & -15 & 55 & -21 & 29 \\
\hline $1993-1998$ & 5 & -7 & 16 & 10 & 28 \\
\hline $1998-2001$ & 3 & 10 & 15 & 26 & 25 \\
\hline $2001-2003$ & 2 & -12 & 1 & -13 & 22 \\
\hline $2003-2004$ & 1 & 1 & 16 & 23 & 24 \\
\hline \hline Total: & 119 & -161 & 208 & -202 & 355 \\
\hline \hline
\end{tabular}




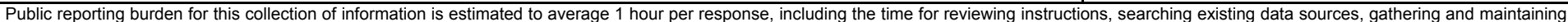

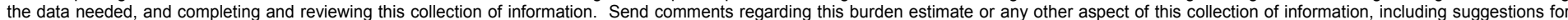

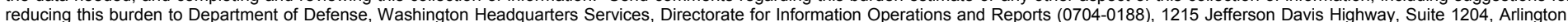

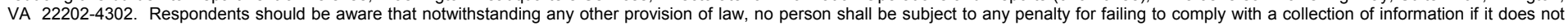
display a currently valid OMB control number. PLEASE DO NOT RETURN YOUR FORM TO THE ABOVE ADDRESS.

\begin{tabular}{l|c}
$\begin{array}{l}\text { 1. REPORT DATE (DD-MM-YYYY) } \\
\text { April } 2006\end{array}$ & $\begin{array}{c}\text { 2. REPORT TYPE } \\
\text { Final report }\end{array}$ \\
\hline
\end{tabular}

\section{TITLE AND SUBTITLE}

Evaluation of Downdrift Shore Erosion, Mattituck Inlet, New York: Section 111 Study

3. DATES COVERED (From - To)

5a. CONTRACT NUMBER

5b. GRANT NUMBER

5c. PROGRAM ELEMENT NUMBER

5d. PROJECT NUMBER

5e. TASK NUMBER

5f. WORK UNIT NUMBER

8. PERFORMING ORGANIZATION REPORT NUMBER

ERDC/CHL TR-06-1

U.S. Army Engineer Research and Development Center

Coastal and Hydraulics Laboratory

3909 Halls Ferry Road

Vicksburg, MS 39180-6199

\section{SPONSORING / MONITORING AGENCY NAME(S) AND ADDRESS(ES)}

U.S. Army Engineer District

26 Federal Plaza

New York, NY 10278-0090
10. SPONSOR/MONITOR'S ACRONYM(S)

11. SPONSOR/MONITOR'S REPORT NUMBER(S)

\section{DISTRIBUTION / AVAILABILITY STATEMENT}

Approved for public release; distribution is unlimited.

\section{SUPPLEMENTARY NOTES}

\section{ABSTRACT}

This report was prepared for the U.S. Army Engineer District, New York, to evaluate shore erosion in response to construction of the Federal navigation project at Mattituck Inlet, NY, under the authority of Section 111 of the River and Harbor Act of 1968, Public Law 90-483, approved August 1968. The original navigation project was authorized in 1896 and modified in 1935 and 1964 . The report is organized into seven chapters and two appendixes. Chapter 1 gives an introduction to Section 111 authority and the physical setting at the study site. Chapter 2 discusses shoreline change and change rates in the vicinity of Mattituck Inlet. Shoreline change rates are calculated for the region and compared for shorelines adjacent to the inlet. Chapter 3 describes numerical simulations of waves, waveinduced and tidal currents, and sediment transport pathways at the inlet. Chapter 4 develops the sediment budget for the site and region. Chapter 5 describes estimated future conditions without a project. Chapter 6 evaluates the responsibility of the Federal government for downdrift shore erosion, and Chapter 7 presents alternatives for mitigation. Appendixes A and B document analysis results for shoreline change.

\section{(Continued)}

\begin{tabular}{|c|c|c|c|c|c|}
\hline \multirow{3}{*}{\multicolumn{2}{|c|}{$\begin{array}{l}\text { 15. SUBJECT TERMS } \\
\text { Breaching } \\
\text { Coastal inlet }\end{array}$}} & \multicolumn{2}{|l|}{ Jetties } & \multicolumn{2}{|c|}{ Navigation channel } \\
\hline & & \multicolumn{2}{|c|}{ Long Island Sound, NY } & \multicolumn{2}{|c|}{ Sediment budget } \\
\hline & & \multicolumn{2}{|c|}{ Longshore sediment transport } & \multicolumn{2}{|c|}{ Shoreline change } \\
\hline \multicolumn{3}{|c|}{ 16. SECURITY CLASSIFICATION OF: } & $\begin{array}{l}\text { 17. LIMITATION } \\
\text { OF ABSTRACT }\end{array}$ & $\begin{array}{l}\text { 18. NUMBER } \\
\text { OF PAGES }\end{array}$ & $\begin{array}{l}\text { 19a. NAME OF RESPONSIBLE } \\
\text { PERSON }\end{array}$ \\
\hline $\begin{array}{l}\text { a. REPORT } \\
\text { UNCLASSIFIED }\end{array}$ & $\begin{array}{l}\text { b. ABSTRACT } \\
\text { UNCLASSIFIED }\end{array}$ & $\begin{array}{l}\text { c. THIS PAGE } \\
\text { UNCLASSIFIED }\end{array}$ & & 126 & $\begin{array}{l}\text { 19b. TELEPHONE NUMBER (include } \\
\text { area code) }\end{array}$ \\
\hline
\end{tabular}




\section{ABSTRACT (Concluded)}

Federal responsibility for erosion downdrift of the Mattituck Inlet navigation project is determined by two approaches. The first approach evaluates the response of the adjacent shorelines to the project and is termed "explicit" because it gives a direct measure of shoreline recession and advance, hence, eroded and accreted volume, respectively, under standard assumptions. The evaluation includes measured shoreline change and the volume of material impounded updrift of the inlet. The second approach considers responses of the downdrift shoreline evaluated through a sediment budget and is termed "implicit" because it is based on transport rates alongshore and across shore that cannot be directly measured. Removal of material by maintenance dredging, as well as sand and gravel mining under both Federal and local permits, are addressed within the implicit approach.

Three alternatives are evaluated for mitigating shore erosion downdrift of Mattituck Inlet. The first alternative continues the present practice of beneficial placement of dredged material on downdrift beaches. This alternative effectively mitigates shore erosion only in the primary erosion area. The second alternative involves annual bypassing of material impounded updrift of the west jetty to downdrift beaches. This activity would increase bypassing rates to an estimated 75 percent of the average annual longshore transport rate. Benefits of this alternative include stabilization of the primary and secondary erosion areas, increased storm protection through wider beaches, and elimination of potential spit breaching adjacent to the inlet. This alternative improves on existing practice and does not mitigate past damage to the downdrift shorelines. The third alternative provides for advanced bypassing of material accumulated in the impoundment fillet, in addition to removal of portions of the flood shoal. An estimated volume of $125,000 \mathrm{cu}$ yd of material is available from these borrow areas for placement on downdrift beaches. The primary benefit of this alternative is increased storm protection along downdrift beaches, eliminating additional land losses and rebuilding costs associated with the Federal navigation project. Additional benefits include reduction of shoaling rates in the navigation channel, improvement of the channel condition, and enhanced circulation in Mattituck Creek. 